\title{
UM CINEMA EXPANDIDO: \\ A EXPERIÊNCIA TEÓRICO-PRÁTICA DA ESCOLA LIVRE DE CINEMA DE NOVA IGUAÇU
}

Tese de Doutorado

Tese apresentada ao Programa de Pós-graduação em Comunicação da PUC-Rio como requisito parcial para obtenção do grau de Doutora em Comunicação.

Orientador: Prof. Miguel Serpa Pereira Co-orientador: Prof. Federico Pierotti 


\title{
UM CINEMA EXPANDIDO: A EXPERIÊNCIA TEÓRICO-PRÁTICA DA ESCOLA LIVRE DE CINEMA DE NOVA IGUAÇU
}

\begin{abstract}
Tese apresentada ao Programa de Pós-graduação em Comunicação da PUC-Rio como requisito parcial para obtenção do grau de Doutora em Comunicação. Aprovada pela Comissão Examinadora abaixo assinada.
\end{abstract}

Prof. Miguel Serpa Pereira Orientador

Departamento de Comunicação - PUC-Rio

Prof. José Carlos Souza Rodrigues Departamento de Comunicação - PUC-Rio

Prof. André Guimarães Brasil Universidade Federal de Minas Gerais - UFMG

Profa $^{\text {. Angeluccia Bernardes Habert }}$ Departamento de Comunicação - PUC-Rio

Prof ${ }^{a}$. Tatiana Oliveira Siciliano Departamento de Comunicação - PUC-Rio

Prof. Federico Pierotti - Co-orientador no exterior Università degli Studi di Firenze - UniFi

Profa. Mônica Hertz Vice-Decana de Pós-graduação do CCS 
Todos os direitos reservados. É proibida a reprodução total ou parcial do trabalho sem autorização do autor, do orientador e da universidade.

\section{Theresa Christina Barbosa de Medeiros}

Mestre pelo Programa de Pós-graduação em Estudos da Mídia, da Universidade Federal do Rio Grande do Norte (2011), com graduação em Comunicação Social - habilitação em Jornalismo, pela Universidade Federal do Rio Grande do Norte (2007). Tem formação técnica e experiência na área de web design, ênfase em web criação e design de interface. Possui experiência docente nas áreas de fotografia e iluminação, cinema, direção de arte, estética e planejamento gráfico.

Ficha Catalográfica

Medeiros, Theresa Christina Barbosa de

Um cinema expandido : a experiência teórico-prática da Escola Livre de Cinema de Nova Iguaçu / Theresa Christina Barbosa de Medeiros ; orientador: Miguel Serpa Pereira ; co-orientador: Federico Pierotti. - 2017.

186 f. : il. color. ; $30 \mathrm{~cm}$

Tese (doutorado)-Pontifícia Universidade Católica do Rio de Janeiro, Departamento de Comunicação Social, 2017.

Inclui bibliografia

1. Comunicação Social - Teses. 2. Cinema. 3. Escola Livre de Cinema de Nova Iguaçu. 4. Processo de criação. 5. Oficina de audiovisual. 6. Experiência. I. Pereira, Miguel Serpa. II. Pierotti, Federico. III. Pontifícia Universidade Católica do Rio de Janeiro. Departamento de Comunicação Social. IV. Título.

CDD: 302.23 
Para Diogo, pelos sorrisos.

Para Francisca, minha mãe, por sempre ter me permitido sonhar. 


\section{Agradecimentos}

A Deus: paternidade, constância e direção.

À Márcia, Diogo, Natan e Riva, que foram os participantes mais frequentes do meu processo de criação. Obrigada pela paciência com os bastidores e pelos abraços que me acalmam.

Aos meus pais, que me ajudaram a lidar com a distância e por me ensinarem a cada dia um pouco mais sobre o amor e a necessidade de lutar pelo que se sonha.

À minha família, que é o alicerce das minhas construções: pais, irmãos, sobrinhos, tios, primos, avós e madrinha. Obrigada pela torcida e pelo amor.

À Márcia Pugas, pela escuta atenta, pelas inúmeras horas gastas lendo este trabalho e pelos toques precisos.

À Libny Freire, pelo ombro nordestino e risadas providenciais.

Ao Tonny Marques, pelo café que me ajudou a ficar acordada.

Ao Davi Severiano e Agda Aquino, amigos que hoje estão longe, mas que sempre se esforçam para estar perto. Eles, de quem sinto tanta saudade.

À família Barros Pascoal, longe nos quilômetros... Perto com o coração.

À Vânia Rodrigues e sua família, que se alegram com minhas conquistas e participam dos momentos difíceis em oração. Já podemos fazer uma segunda road trip.

Ao professor Miguel Pereira, por acreditar nesta pesquisa e me apoiar durante estes anos. Especialmente por suas palavras acalentadoras "tudo vai acabar bem". Obrigada, professor. Acabou mais essa etapa.

Aos funcionários e alunos da PUC-Rio, pelo tempo compartilhado e pelo trabalho conjunto.

Ao professor Federico Pierotti: mestre, amigo e parceiro de pesquisa e projetos. Espero que este seja apenas o começo.

Aos professores do SAGAS - Dipartimento di Storia, Archeologia, Geografia, Arte, Spettacolo da Università di Firenze, pela receptividade, acolhida e respeito por esta pesquisa durante o período do meu estágio na Itália.

À Elisa Uffreduzzi e Paolo Angelini que, com Federico, me proporcionaram os melhores programas e conversas durante os meses em Firenze. 
Aos alunos e mediadores da Escola Livre de Cinema de Nova Iguaçu, pelo amor pelas imagens e pelas descobertas que compartilharam comigo.

Aos professores e colegas que encontrei durante este percurso no Rio de Janeiro e na Itália: André Brasil (UFMG), Cezar Migliorin (UFF), Fernanda Bruno (UFRJ), Isaac Pipano (UFF), Sandra Lischi (Università di Pisa) e Marco Bertozzi (Università IUAV di Venezia). Obrigada pelas aulas inspiradoras, pelos debates e troca de ideias.

À SOCINE: local de encontro, de debates, onde "pratiquei a alteridade" e ouvi importantes apontamentos para esta pesquisa.

Ao Silvio Tendler, pelos desafios que reafirmaram em mim a convicção da escolha pela sala de aula.

Agradeço às instituições que possibilitaram a pesquisa: Programa de PósGraduação em Comunicação da PUC-Rio; Università degli Studi di Firenze (UniFi) e Capes (Coordenação de Aperfeiçoamento de Pessoal de Nível Superior). 


\section{Resumo}

Medeiros, Theresa Christina Barbosa de; Pereira, Miguel; Pierotti, Federico. Um cinema expandido: a experiência teórico-prática da Escola Livre de Cinema de Nova Iguaçu. Rio de Janeiro, 2017. 186p. Tese de Doutorado - Departamento de Comunicação, Pontifícia Universidade Católica do Rio de Janeiro.

Esta pesquisa investiga o processo de criação cinematográfico a partir da experiência teórico-prática da Escola Livre de Cinema de Nova Iguaçu (ELC), localizada no bairro de Austin, na região da Baixada Fluminense. Trata-se de um estudo realizado durante o ano de 2014, a partir de uma aproximação com a metodologia da escola e da observação das aulas de uma das turmas especificamente dos dispositivos de criação que culminaram na videodança Montão de Coisa. A empiria apresentada está pautada nos registros das oficinas de audiovisual ministradas pelos mediadores da escola, nas anotações em caderno de campo, em registros fotográficos e vídeos feitos pela pesquisadora, no material publicizado pela ELC e também em duas entrevistas com a produtora, concedidas ao longo da pesquisa de campo. Advindas dos conceitos norteadores da metodologia da ELC, as categorias corpo, palavra e território aparecem nesta tese como chaves de leitura do processo de criação a fim de evidenciar as relações que permeiam o fazer cinematográfico na experiência da escola e mobilizam a criação da videodança em questão. A análise empreendida revela como o encontro destes sujeitos com o cinema, atravessado por processos criativos e subjetivos, permite que estes vivenciem uma experiência de alteridade, ou seja, de encontro com o outro e o mundo. Ao mesmo tempo, as tensões que permeiam este processo potencializam o encorajamento estético, dando, pois, a essa experiência também um caráter estético. Enquanto a palavra aparece como forma de expressão, enfatizando um campo simbólico, valorizando as singularidades linguísticas e gestuais dos alunos e mediadores, o corpo surge com suas tensões (aquele que opera a câmera e aquele que é filmado por ela) e a gestualidade extraída, trazida e trabalhada pelos alunos e mediadores. Por fim, é "com" e "no" território que essas ações se efetivam, tornando-o uma peça fundamental para entender como as 
ações de criação da ELC acontecem. Assim sendo, pensando o cinema expandido como aquele que ultrapassa os limites do cinema convencional (aquele cristalizado pelo cinema industrial e de entretenimento) e se projeta em outras telas, em outros espaços, conclui-se ser este o cinema vivenciado em Austin. Visto pelo viés de uma expansão, em meio às ações que são frutos dos dispositivos e das tensões que permeiam o processo de criação, ele [o cinema] se constitui em meio à inventividade do cotidiano daquele espaço e à criatividade dos sujeitos envolvidos.

\section{Palavras-chave}

Cinema; Escola livre de Cinema de Nova Iguaçu; processo de criação; oficina de audiovisual; experiência; alteridade; encorajamento estético; videodança; cinema expandido; Austin. 


\section{Abstract}

Medeiros, Theresa Christina Barbosa de; Pereira, Miguel (advisor); Pierotti, Federico (co advisor). An expanded cinema: the theoreticalpractical experience of the Nova Iguaçu Free Cinema School. Rio de Janeiro, 2017. 186p. Tese de Doutorado - Departamento de Comunicação, Pontifícia Universidade Católica do Rio de Janeiro.

This research investigates the cinematographic process of creation from the theoretical-practical experience of the Free Cinema School of Nova Iguaçu (ELC), located in the neighborhood of Austin, in the Baixada Fluminense region. It is a study carried out during 2014, based on an approach to the school methodology and observing the lessons of one of its classes - specifically the tools that culminated in the creation of the Montão de Coisa (Heap of Thing) videodance. The empirical research presented here is based on the records of the audiovisual workshops given by the school mediators, notes in field notebook, photographic records and videos made by the researcher, on the material publicized by ELC and also on two interviews with the producer, given during field research. Originating from the concepts of ELC methodology, the categories body, word and territory appear in this thesis as keys to the reading of the creation process in order to highlight the relations that permeate the cinematographic making in the school experience and that mobilize the creation of the aforementioned videodance. The undertaken analysis reveals how the encounter of these subjects with the cinema, crossed by creative and subjective processes, allows them to experience an experience of otherness, that is, of encounter with the other and with the world. In addition, the tensions that permeate this process potentiate the aesthetic encouragement, thus giving to this experience also an aesthetic character. While the word appears as a form of expression, emphasizing a symbolic field, and valuing the linguistic and gestural singularities of students and mediators, the body emerges with its tensions (the one that operates the camera and the one that is filmed by it) and the gesture extracted, brought and addressed by the students and mediators. At last, it is "with" and "in the" territory that these actions take place, making it a fundamental piece to understand how the actions of creation of the ELC happen. Thus, thinking 
of the expanded cinema as one that goes beyond the limits of conventional cinema (that one crystallized by industrial and entertainment cinema) and that is projected on other screens, in other spaces, it is concluded that this is the cinema experienced in Austin. Seen by the bias of an expansion, amid the actions that are outcome of the "dispositif" and tensions that permeate the process of creation, it [the cinema] is constituted amongst the inventiveness of the daily life of that space and the creativity of the involved subjects.

\section{Keywords}

Cinema; Nova Iguaçu Free Cinema School; creation process; audiovisual workshop; experience; alterity; aesthetic encouragement; videodance; expanded cinema; Austin. 


\section{Riassunto}

Medeiros, Theresa Christina Barbosa de; Pereira, Miguel (tutor); Pierotti, Federico (co tutor). Un cinema espanso: l'esperienza teorico pratica della Escola Livre de Cinema de Nova Iguaçu. Rio de Janeiro, 2017. 186p. Tese de Doutorado - Departamento de Comunicação, Pontifícia Universidade Católica do Rio de Janeiro.

Questa tesi investiga il processo di creazione cinematografico partendo dall'esperienza teorico pratica della Escola Livre de Cinema de Nova Iguaçu (ELC), ad Austin, quartiere della città di Nova Iguaçu, nella regione della Baixada Fluminense. Trattasi di uno studio fatto durante l'anno di 2014, a partire da un aproccio alla metodologia della scuola e da osservazioni frequenti delle lezioni di una delle classi - soprattutto dei "dispositif" di creazione che hanno raggiunto la videodanza Montão de Coisa. L'empiria presentata è basata sui registri fotografici e di video delle officine audiovisuali fatte dai mediatori della scuola, sugli appunti di audiovisuale in quaderno di campo, sui registri fotografici e video registrati da una ricercatrice, presenti nel materiale publicizzato dalla ELC e anche attraverso due interviste con la produttrice, avvenute durante la ricerca sul campo. Provenute dai concetti che orientano verso un nord della metodologia della ELC, le categorie corpo, parola e territorio appaiono in questa tesi come chiavi di lettura del processo di creazione con la finalità di evidenziare i rapporti che permeano il fare cinematografico nell'esperienza della scuola e che mobilitano la creazione della videodanza in questione. L'analisi effettuata rivela come l'incontro dei soggetti citati con il cinema, attraversato da processi creativi e soggettivi, permette che questi stessi processi vivano un'esperienza di alterità ossia, di incontro con l'altro e il mondo. Allo stesso tempo, le tensioni che permeano questo processo potenziano l'incoraggiamento estetico dando, pertanto, a quella sperienzza un carattere estetico anche. Mentre la parola appare come forma di espressione, enfatizzando un campo simbolico, valorizzando le singolarità linguistiche e di gesti degli alunni e dei mediatori, il corpo sorge con le sue tensioni - quel soggetto che opera la telecamera e quel che è filmato da essa - e la gestualità esttrata, portata e lavorata dagli alunno e dai mediatori. Infine, è "con" e "nel" territorio che queste azioni si effettuano, rendendolo un oggetto fondamentale per comprendere come le azioni di creazione della ELC avvengono. Allora, pensando 
al cinema espanso como quel che oltrepassa i limiti del cinema convenzionale quel cinema cristalizzato dal cinema industriale e di intrattenimento - e si proieta in altri schermi, in altri spazi, si può dunque concludere col dire che è questo il cinema sperimentato ad Austin. Visto da questa prospettiva di un'espansione, nel mezzo delle azioni che sono state prodotte da questi "dispositif" e dalle tensioni che permeano il processo di creazione, il cinema si costituisce in mezzo all'inventività del quotidiano di quello spazio e alla creatività dei soggetti coinvolti.

\section{Parole chiave}

Cinema; Escola Livre de Cinema de Nova Iguaçu; processo di creazione; officina audiovisuale; esperienza; alterità; incoraggiamento estetico; videodanza; cinema espanso; Austin 


\section{Sumário}

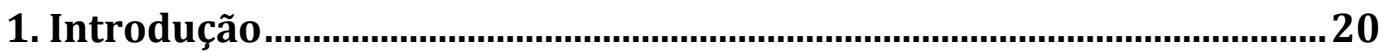

2. Uma escola, de cinema ...............................................................................23

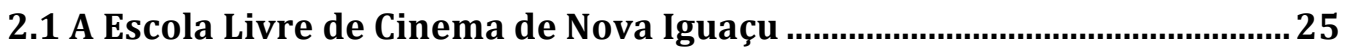

2.2 Criação cinematográfica, processos de criação, oficinas e contextos de

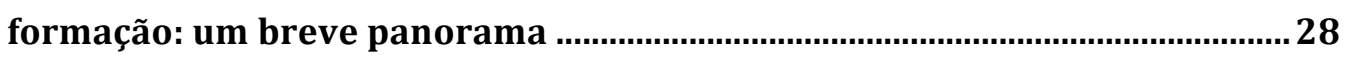

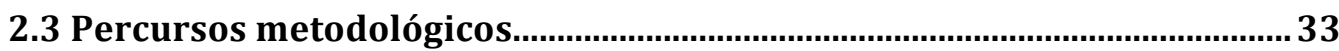

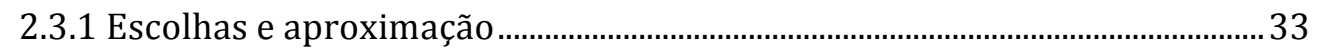

2.3.2. Notas sobre a escolha pelo processo de criação …………………………….....37

2.3.3. Cartografar é preciso: sobre a construção da empiria ....................................40

3. De onde veio este Montão de Coisas? .....................................................51

3.1 Para ler o processo criativo da videodança.................................................51

3.2. A dimensão da experiência no processo de criação ……………………..... 54

3.2.1 A experiência estética na arte contemporânea ………………………………....56

3.2.2 A experiência estética no documentário contemporâneo: trabalhando com o noção de dispositivo …………………………………………………………....5

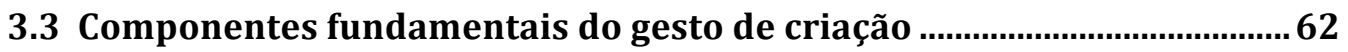

3.3.1 A ideia e o formato, sem roteiro ……………………………………………....... 67

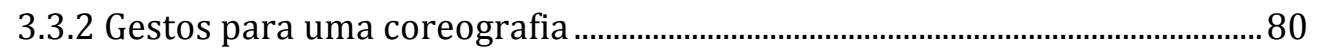

4. Palavra, corpo e território: conceitos de uma metodologia para

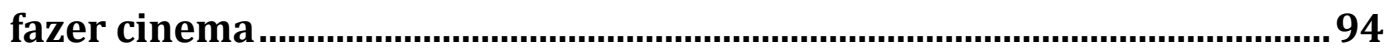

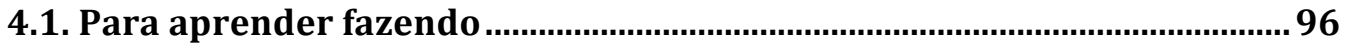

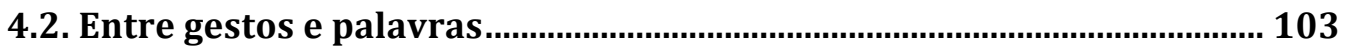

4.3 Corpo: Gestos para uma coreografia ………….................................... 107

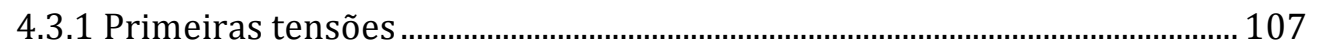

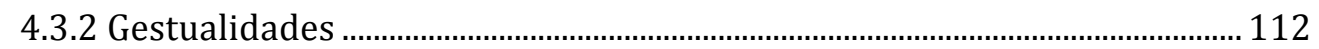

4.4 Território: a caminhada como experiência estética ............................ 118

4.4.1 Para pensar espaço e lugar............................................................................ 119

4.4.2 Caminhos para percorrer: deslocamento e criação ........................................ 123

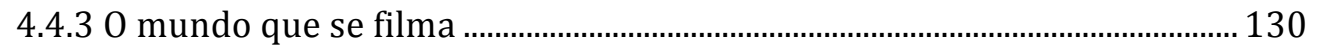


5: Para pensar um outro cinema expandido .............................................. 135

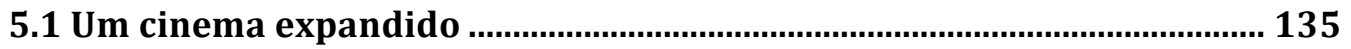

5.1.2 Entre Maya Deren e o percurso pelas ruas de Austin .................................... 137

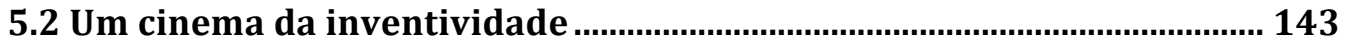

5.3 A potencialidade do cinema

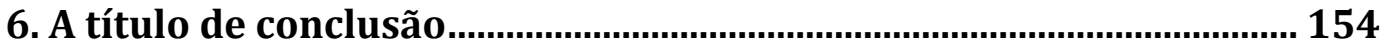

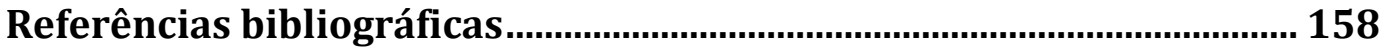

Anexo 1 [............................................................................................................ 164

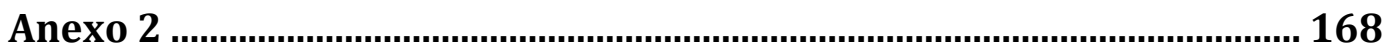

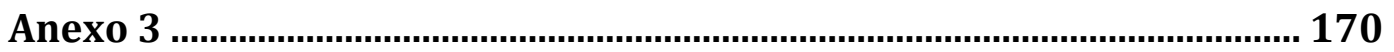

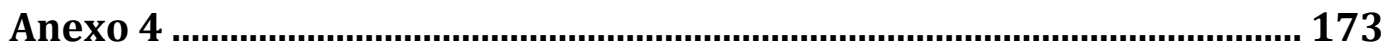

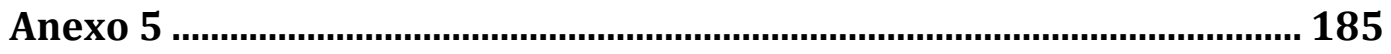




\section{Lista de imagens e tabelas}

Imagem 1 - Frame da videoinstalação \#circulando • crédito da foto: arquivo ELC... 26 Imagem 2 - Toten de exibição dos vídeos da \#circulando • crédito da foto: arquivo

ELC

Imagem 3 - Universo de palavras associadas ao termo "processo de criação

cinematográfica" 31

Imagem 4 - Universo de palavras associadas ao termo "oficinas" ............................ 31

Imagem 5 - Planfleto de divulgação da turma de videoarte 2014 - créditos: ELC ..... 37

Imagem 6 - Alunos e mediadores em gravação pelas ruas de Austin (08/08/2014) •

créditos: Theresa Medeiros

Imagem 7 - Material de pesquisa: anotações, narrativas e imagens - créditos:

Theresa Medeiros

Imagem 8 - Conjunto de frames da abertura da videoinstalação \#QueroSer -

créditos: ELC

Imagem 9 - Frame a) e b) do vídeo da \#circulando - créditos: ELC.

Imagem 10 - a) fachada da ELC em Austin | b, c e d) exercícios para deixar a

imagem circular: dispositivos de gravação - créditos: ELC

Imagem 11 - Gravação de vídeos para \#Circulando - créditos: ELC

Imagem 12 - Fotos de bastidores da execução do exercício de gravação para o

Minuto Lumière, centro de Austin - créditos: ELC ............................................. 73

Imagem 13 - Frames iniciais do vídeo Montão de Coisa - créditos: ELC .................. 76

Imagem 14 - Fragmento do exercício de sondagem com os alunos da turma $\mathrm{C} \bullet$

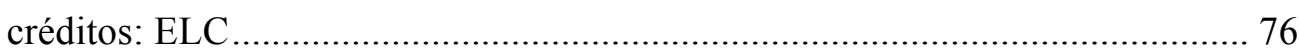

Imagem 15 - Mediadora em sala com os alunos - aula 22 - créditos: ELC ................ 81

Imagem 16 - Desenvolvimento de exercício prático • créditos: ELC ….................... 83

Imagem 17 - Exercício de observação, aula 30 • créditos: ELC ……………............. 83

Imagem 18 - Aula 34: execução e manipulação de gestos - créditos: ELC................. 85

Imagem 19 - Apresentação de referências para o videodança final • créditos: ELC.. 86

Imagem 20 - Obras apresentadas Bispo do Rosário: utilizadas pelos alunos e

mediadores da ELC para pensar como agrupar objetos e fazer relações -

créditos: Museu Bispo do Rosário.

Imagem 21 - Frames da coleção de materialidades: padrões catalogados pelas ruas de Austin - créditos: ELC. 
Imagem 22 - a) apresentação do projeto Re:Rosas | b) Frame de Rosas danst

Rosas.

Imagem 23 - Frames da Videodança Montão de Coisa: interação com as cadeiras -

créditos: ELC

Imagem 24 - a), b) e c): Frames Montão de Coisa - estudo comparativo para

observar a composição visual - créditos da foto: ELC

Imagem 25 - a), b) e c): Frames do filme Batalha do Passinho (Emílio Domingos,

2012), referência para composição visual 91

Imagem 26 - a), b) e c): Frames do videoclipe Passinho do Romano (Bonde TNT e

Lucas Santos), referência para composição visual.

Imagem 27 - Frames do videoclipe da música Kagado, Os Kazumbis feat Cabo

Snoop, referência para composição visual

Imagem 28 - O que eu vi: desenhos feitos pelos alunos da ELC como atividade

complementar à caminhada silenciosa • créditos: ELC.

Imagem 29 - O que eu vi: desenhos feitos pelos alunos da ELC como atividade

complementar à caminhada silenciosa (foto 2) • crédidos: ELC

Imagem 30 - Fotos a) e b): Gravações externas para o Minuto Lumière • créditos:

ELC

Imagem 31 - Grupo de frames: Mobile Men (Apichatpong Weerasethakul)....

Imagem 32 - a) Gravação interna na ELC | b) detalhe: aluna fazendo making off •

créditos: Theresa Medeiros

Imagem 33 - Frames de Screen Test, uma série de filmes (filmes retrato) em

silêncio, gravados por Warhol. O artista fez as imagens numa câmera 16 mm,

por vários minutos ininterruptos para observar a relação com a câmera.

Imagem 34 - Por onde passei: descrevendo a caminhada pelas ruas de Austin -

créditos: ELC

Imagem 35 - Alunos durante exercício de percepção do gesto do outro • créditos:

ELC

Imagem 36 - Catálogos e referências: estudo sobre o trabalho da coreógrafa Pina

Bausch

Imagem 37 - Frames do Minuto Lumière, Turma C - a) e c) primeira gravação

e b) e d) regravação - créditos: ELC

Imagem 38 - Frames a) e b): catalogando gestos em Austin: encontro com a moça

distribuindo panfleto na passarela (aula 38) - créditos: coleção ELC 
Imagem 39 - Frames a) e b): Estudo sobre os gestos das ruas - moça distribuindo panfletos \#1 (aula 44) - créditos: coleção ELC

Imagem 40 - Frames a) e b): Estudo sobre os gestos das ruas - moça distribuindo panfletos \#2 (aula 49)- créditos: coleção ELC

Imagem 41 - Estudo sobre os gestos das ruas - moça distribuindo panfletos \#3

(aula 50) - créditos: coleção ELC

Imagem 42 - Estudo sobre os gestos das ruas - moça distribuindo panfletos \#4

(aula 51) - créditos: coleção ELC

Imagem 43 - Frames a) e b): Execução do gesto na coreografia de Montão de

Coisa - ELC, 2014

Imagem 44 - Conjunto de frames do vídeo que compila dos exercício de raccord

feitos em sala - Créditos: ELC

Imagem 45 - Conjunto de frames da videodança Montão de Coisa - créditos: ELC

Imagem 46 - Aula 36 na ELC: Trabalhando a coreografia Re:Rosas, da coreógrafa

Anne Tereza De Keersmaeker - Créditos: ELC

Imagem 47 - Bastidores de gravação de Montão de Coisa - coreografia com

cadeiras - créditos: ELC

Imagem 48 - Frames da videodança Montão de Coisa: Gestos deslocados -

créditos: ELC

Imagem 49 - Exemplo de filtro por mês e diário das aulas dia a dia - créditos:

Theresa Medeiros.

Imagem 50 - Exemplo de filtro por tipo de material - créditos: Theresa Medeiros . 185

Imagem 51 - Exemplo de registro de fotos por aula e etiquetas com

palavras-chave - créditos: Theresa Medeiros..

Imagem 52 - Exemplo de registro de aula e etiquetas com palavras-chave -

créditos: Theresa Medeiros

Tabela 1 - Quantidade de teses encontradas por termos de pesquisa

Tabela 2 - Jogo de palavras para pensar a caminhada como experiência estética versão adaptada para esta tese, com base em Careri (2013) 


\section{Lista de abreviaturas e siglas}

ANT - Actor-network Theory

Capes - Coordenação de Aperfeiçoamento de Pessoal de Nível Superior

CINEAD - Cinema para aprender e desaprender

ECO(UFRJ) - Escola de Comunicação da Universidade Federal do Rio de Janeiro

ELC - Escola Livre de Cinema de Nova Iguaçu

GEIN - Grupo de Estudos em Educação Infantil (UFRGS)

GRUPEM - Grupo de pesquisa em educação e mídia (PUC-Rio)

IBGE - Instituto Brasileiro de Geografia e Estatística

ICMS - Imposto sobre circulação de mercadorias e serviços

LINCE - Linguagens, Infância e educação (UNISC)

MAM - Museu de Arte Moderna

MiC - Ministério da Cultura

NICA - Núcleo Infância, Comunicação, cultura e arte (UFSC)

ONG - Organização não governamental

OSCIP - Organização da Sociedade Civil de Interesse Público

PAA - Programa de Alfabetização Audiovisual

PDSE - Programa de Doutorado Sanduíche no Exterior

PPGCOM - Programa de Pós-graduação em Comunicação

PUC-Rio - Pontifícia Universidade Católica do Rio de Janeiro

SAGAS - Dipartimento di Storia, Archeologia, Geografia, Arte, Spettacolo da

Università di Firenze

SOCINE - Sociedade Brasileira de Estudos de Cinema e Audiovisual

TAR - Teoria do Ator-rede

UFF - Universidade Federal Fluminense

UFRGS - Universidade Federal do Rio Grande do Sul

UFRJ - Universidade Federal do Rio de Janeiro

UFSC - Universidade Federal de Santa Catarina

UniFi - Università degli Studi di Firenze

UNISC - Universidade de Santa Cruz do Sul

USP - Universidade de São Paulo 


\section{Apresentação}

Esta tese é resultado da pesquisa intitulada "Um cinema expandido: a experiência teórico-prática da Escola Livre de Cinema de Nova Iguaçu", desenvolvida no Programa de Pós-graduação em Comunicação da PUC-Rio e vinculada à Linha de Pesquisa Comunicação e Produção, sob a orientação do Professor Doutor Miguel Serpa Pereira. Cabe ainda destacar que parte desta pesquisa foi desenvolvida no departamento de História, Arqueologia, Geografia, Arte e Espetáculo - SAGAS da Università degli Studi di Firenze, sob a orientação do Professor Doutor Federico Pierotti, o desenvolvimento deste estágio durante o doutorado foi viabilizado pelo Programa Institucional de Bolsas de Doutorado Sanduíche no Exterior - $\mathrm{PDSE}^{1}$, por meio deste estágio pude conhecer a estrutura e história de algumas escolas de cinema na Itália, seus filmes e outros projetos que trabalham a relação do cinema e educação. Desta forma, é comum que ao longo do texto o leitor encontre referência a estes.

\footnotetext{
${ }^{1}$ Bolsista da CAPES - processo n ${ }^{\circ}$ BEX 3842/15-0
} 


\section{Introdução}

(...) a primeira característica de uma imagem cinematográfica é que ela 'sofre' o mundo, é afetada por ele. Há aí uma dimensão documental fortíssima que nos mobiliza na fotografia e no cinema. As imagens são fruto de um encontro entre uma máquina, um sujeito - ou vários - e algo que está no mundo. (MIGLIORIN, 2015, p. 35)

A experiência de criação da imagem cinematográfica e seu encontro com/no mundo, bem como as relações que dela se desdobram, mobilizam o fazer pesquisa nesta tese. O viés pelo qual se deu todo o trabalho aqui apresentado privilegiou a experiência da Escola Livre de Cinema de Nova Iguaçu explorando sua metodologia de trabalho e também seu processo de criação das imagens, entendendo que os filmes que são ali produzidos carregam marcas próprias, tendo em vista as contingências de sua existência. Nesse sentido, procurei pensar a imagem cinematográfica como sendo fruto de um encontro entre quem a pensou/criou/fez e o mundo, o outro.

Este encontro com a alteridade se dá em meio a uma proposta de criação cinematográfica que aproxima os alunos da escola do cinema como arte e como fruto de um gesto de criação. O empreendimento inicial deste trabalho teve como foco entender a relação de "aprender fazendo". No entanto, ao longo das leituras e análises do processo vivenciado percebi que esta relação é melhor representada, para além de um dilema retórico, por um "fazer aprendendo", ou seja, é diante das ações de criação das imagens que o aprendizado se dá. Criar coisas. Isso é inerente ao homem. A ELC explora o viés da criatividade com seus alunos utilizando dispositivos fílmicos como estratégia de criação. São situações que demandam ações de criação.

Pensar a metodologia da ELC permitiu entender ser esta uma forma resiliente de trabalhar em um cenário permeado por tensões. Nesse sentido, apresento alguns dos aspectos que considero importantes e potencialmente produtivos para esta pesquisa: a existência de uma experiência que vê no deslocamento (no caminhar), uma prática estética e ao mesmo tempo nos permite pensar as diferenças e as igualdades na relação dos mediadores com os alunos. A 
prática estética, a alteridade, os encontros, as diferenças e igualdades são elementos que tocam a criação e passam a fazer parte do contexto que mobiliza a criação do filme. No processo de criação, estas questões encontram um terreno fértil para se desenvolver, elas são bem-vindas e se misturam à tensão, ao paradoxo, à intuição, ao rascunho, à ideia de errar. Assumir tais relações significa admitir que trazem outras questões atinentes ao fazer cinematográfico. É oportuno pensar essas relações a partir da ideia de expandir. Imaginando a expansão ainda a partir de espaço, dos deslocamentos, da criação, do engajamento, da estética, da política. A seguir, apresento brevemente um panorama deste trabalho, a fim de guiar o leitor pelos capítulos nos quais a sistematização da pesquisa foi feita ${ }^{2}$.

No capítulo 2 a escola de cinema é apresentada como um projeto e através de questões que tocam o viés da educação não formal, como processo de aprendizagem que possibilita aos indivíduos fazer uma leitura de mundo tendo em vista o que se passa ao seu redor. Em seguida, no capítulo 3, trabalho a problematização desta experiência a partir do seu processo de criação, explorando o contexto e os momentos em que surgem as ideias, tensões, desenvolvimento e criação das imagens. Neste sentido, trabalho os aspectos da linguagem e do processo de criação de um projeto específico: a produção da videodança Montão de Coisa.

No quarto capítulo discuto a forma de trabalho da ELC, através de sua metodologia, problematizando como esta foi alicerçada, questionando como os conceitos base, "palavra, corpo e território" se articulam, no sentido de fazer com que essas imagens surjam. Esta forma de trabalhar me mostrou um cenário permeado por tensões e consensos, diante disto, trato da relação dos alunos com os mediadores e com os aparatos técnicos pertencentes ao fazer cinematográfico e explorados ali, especialmente a relação com a câmera. Pensando naqueles que filmam e também nos que são filmados pela câmera e que servem àquele que executa a videodança. Diante das problematizações este cenário revela uma experiência estética, pautada pela alteridade e na relação com o território, que se evidencia, entre outros momentos, na ação de caminhar pelas ruas do bairro.

\footnotetext{
${ }^{2}$ A numeração dos capítulos da tese seguiu as normas para apresentação de teses e dissertações da PUC-Rio, segundo as quais a introdução é numerada como a primeira parte textual da tese, de modo que este trabalho está organizado em quatro capítulos após a introdução, numerados de 2 a 5 .
} 
No quinto capítulo, diante do cenário que se apresenta, aponto uma possível leitura do que considero como sendo o cinema vivenciado na ELC. A partir da ideia de cinema expandido, trabalho no sentido de pensar um cinema que se expande, ou seja, ultrapassa sua forma previamente dada ou pensada, e também expande as relações que envolvem sua construção. Retomo os apontamentos feitos acerca do processo de criação de Montão de Coisa, as tensões da escolha, o paradoxo da criação, os insights, a intuição e o rascunho para evidenciar aquele que nomeio, nesta tese, como um cinema da inventividade, cujas imagens surgem diante de um cenário: as ruas de Austin. O cinema se faz, assim, mediador das relações que surgem durante a experiência investigada, da relação entre os sujeitos envolvidos, isto é, dos alunos com o território e com o próprio fazer cinematográfico, especialmente o diz respeito ao encorajamento estético. 


\section{Uma escola, de cinema}

Este capítulo tem como objetivo contextualizar as principais discussões propostas nesta tese, onde o processo de criação cinematográfica é tomado como o momento a ser observado e o lugar de onde nasce a empiria construída ao longo da pesquisa. $\mathrm{O}$ foco da investigação foi a metodologia da Escola Livre de Cinema de Nova Iguaçu (ELC), sua a experiência de criação e produção, evidenciando questões relativas aos processos subjetivos que permeiam o momento da criação cinematográfica.

Ao nos aproximarmos desta escola, dos seus princípios metodológicos e filosóficos estamos ao mesmo tempo delineando que tipo de cinema se pretende explorar. Experiências como esta, desenvolvida em Nova Iguaçu, são recorrentes no contexto brasileiro e acontecem especialmente vinculadas a ONGs, OSCIPs, projetos de extensão universitária, projetos sazonais como contrapartidas em projetos de financiamento através de editais públicos e em sua maioria, são desenvolvidas em área periféricas de grandes cidades ${ }^{3}$. São universos que envolvem estudantes, produtores culturais, cineastas, críticos de arte, professores e pesquisadores em espaços partilhados, experiências coletivas.

Ao longo de sua existência a ELC passou por mudanças e adaptações como projeto. Começou como oficinas de audiovisual dentro da escola regular, em pouco tempo ganhou sua própria estrutura física e se estabeleceu como uma escola de cinema, um local de encontro com o cinema através de uma experiência de criação e produção.

Neste sentido, penso a ELC como uma instituição de educação não formal, e considero o território como seu contexto de atuação social e política e como elemento emblemático na construção estética dos filmes que ali são feitos. Gohn (2013) define a educação não formal como "um processo sociopolítico, cultural e pedagógico de formação para a cidadania entendendo o político como a formação do indivíduo para interagir com o outro na sociedade" (versão Kindle - posição $384^{4}$ ), suas práticas se desenvolvem “nas organizações sociais, nos movimentos

\footnotetext{
${ }^{3}$ Toledo (2010) apresenta um panorama das oficinas e cursos livre audiovisuais gratuitos no Brasil na tese "Educação audiovisual popular no Brasil panorama, 1990-2009".

${ }^{4}$ Alguns livros usados nesta tese como referência encontram-se disponíveis na versão e-book do leitor digital Kindle, da empresa Amazon, ainda que a posição exata da citação sofra variações de
} 
sociais, nas associações comunitárias, nos programas de formação sobre direitos humanos, cidadania, práticas identitárias, lutas contra desigualdade e exclusão sociais" (GOHN, 2013, versão Kindle - posição 416).

No que se refere ao trabalho desenvolvido, as oficinas de cinema e audiovisual receberam diversas denominações, sempre pautadas pelo tipo de atividade desenvolvida naquele ano na ELC. Sobre uma possível classificação desse trabalho, ao me aproximar do texto feito por Clarisse Alvarenga desenvolvido para sua dissertação de mestrado, encontrei um fragmento que muito me ajudou a pensar (ou talvez, repensar) o que aqui apresento sobre a Escola Livre de Cinema de Nova Iguaçu. Já nas últimas linhas do texto de introdução, falando sobre o modo de tratar as experiências do vídeo comunitário contemporâneo, Alvarenga (2004) diz:

Ao que me parece, seria mais interessante tratar as experiências do vídeo comunitário contemporâneo não como um trabalho videográfico feito inteiramente pelo cineasta com a proposta de representar uma comunidade pré-existente, nem tampouco como um trabalho feito por uma comunidade com a proposta de se auto-retratar, mas juntamente como um trabalho de troca cultural, viabilizado através do vídeo, entre um grupo heterogêneo de pessoas, que se valem dos recursos técnicos do vídeo para produzir imagens e acabam tornando indiscerníveis as categorias que nos permitiam até então distingui-los ou representá-los" (ALVARENGA, 2004, p. 23 - grifos meus).

O esforço para definir em categorias a produção da ELC é laborioso devido às múltiplas formas que esta pode assumir, de acordo com o enfoque dado. Diante do contexto traçado anteriormente, explicito que a produção aqui estudada e discutida será lida como fruto de um contexto de formação, um lugar onde se aprende fazendo e é justamente neste fazer que reside o foco da investigação. Fazer imagens, criá-las a partir de uma experiência com a linguagem, com o mundo e com o território onde se encontra.

acordo com o dispositivo usado na leitura do e-book, optei por informá-la, no intuito de deixar um norte para a localização da mesma. 


\subsection{A Escola Livre de Cinema de Nova Iguaçu}

Eles usam o contra turno da escola regular para experimentar o cinema, saem de casa e, percorrendo o caminho até o centro do bairro de Austin, chegam à Escola Livre de Cinema, mas ao entrar lá, empolgados com a ideia de estudar cinema, descobrem que não farão um filme. O primeiro dia de aula na ELC é marcado pelo encontro com um cinema que não é feito para ser exibido na sala convencional de cinema, aquela sala toda preta, com um monte de cadeiras e uma tela.

O que a gente faz aqui é exibido em outros espaços. Vocês já
foram a algum museu, centro cultural ou sala de exposição?
Tipo, aqui em Austin não tem esse espaço, por isso fica mais
difícil. (...) O que a gente faz é o que chamamos de
videoinstalação. (Anotação de pesquisa sobre fala da
professora - aula 1). ${ }^{5}$

Essa foi a primeira descoberta daquele dia: um cinema que é exibido em outros espaços e que fala de outras formas. Assim os alunos descobriram o que é uma videoinstalação. Para guiar a explicação os mediadores utilizaram as imagens produzidas pela ELC durante seu último semestre de trabalho: a videoinstalação \#Circulando, que exibe o resultado do processo de criação das turmas de videoarte do segundo semestre de 2013. A \#Circulando foi um trabalho pautado objetivamente em um encontro com o território (com o bairro de Austin) e uma busca por meios de deixar a imagem não-retangular, dando formas circulares a ela. Essa experiência foi guiada pela metodologia da ELC, baseada na tríade: palavra, corpo e território ${ }^{6}$. Os mediadores adaptaram instrumentos, como uma lupa, à câmera para fazer a captação das imagens. Naquele dia, dentre tudo que foi exibido, o mais comum era aquele lugar, o lugar que as imagens mostravam: a mesma rua percorrida para se chegar à escola, a praça onde comumente os alunos encontram seus amigos, a parada onde se espera o ônibus.

\footnotetext{
${ }^{5}$ A organização da produção empírica está apresentada na seção 2.3.2.

${ }^{6}$ A metodologia da ELC será explorada no capítulo 4.
} 


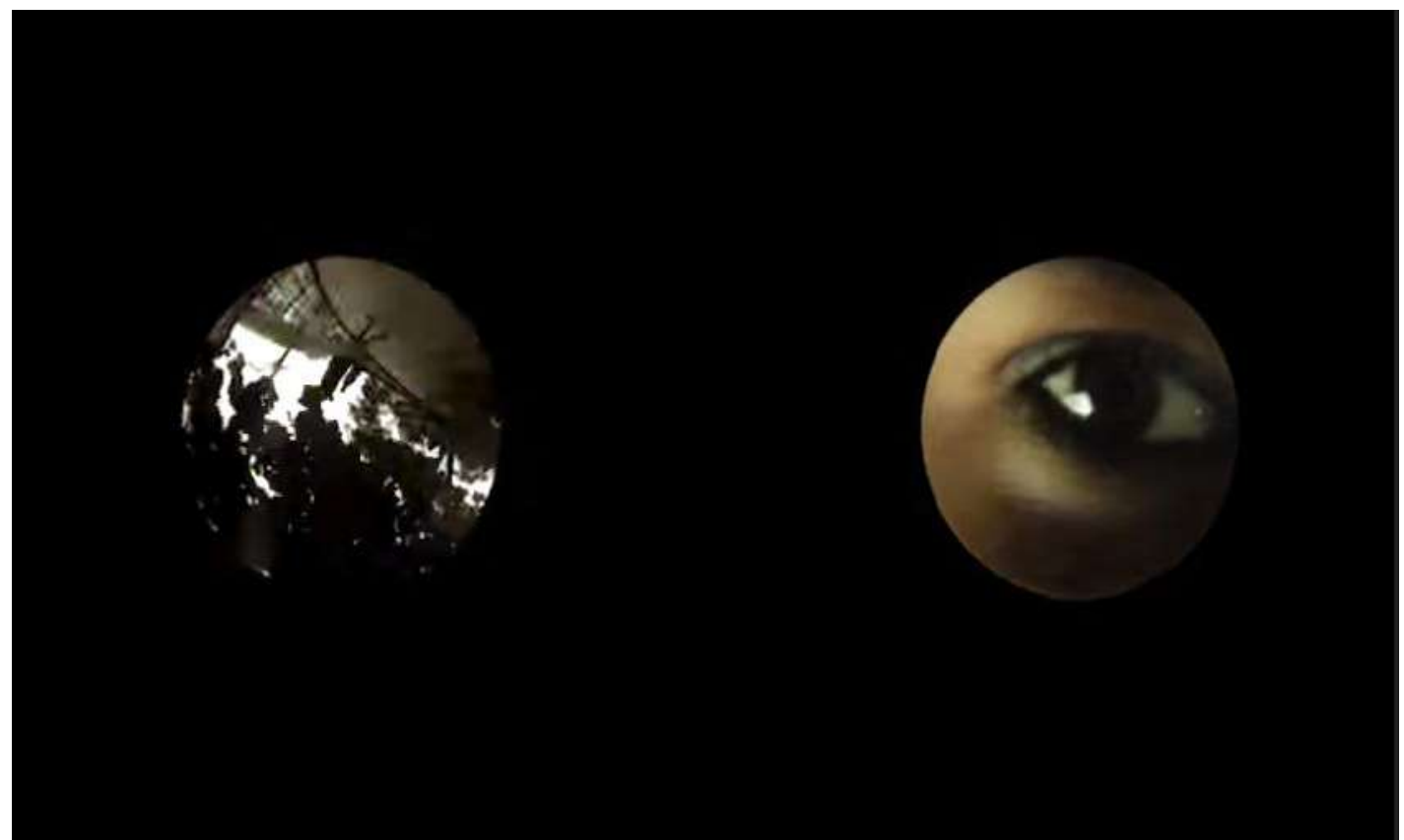

Imagem 1 - Frame da videoinstalação \#circulando • crédito da foto: arquivo ELC

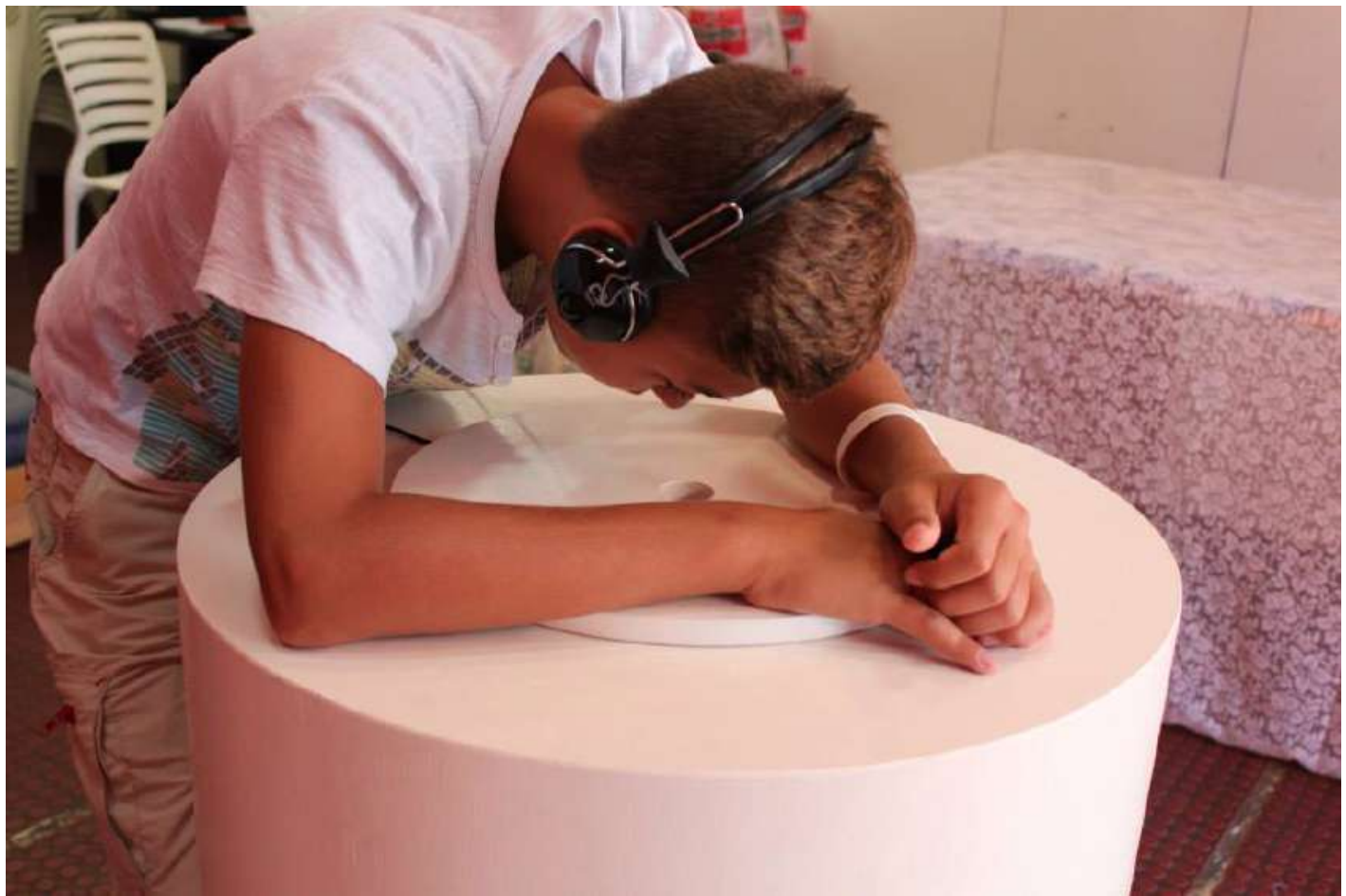

Imagem 2 - Toten de exibição dos vídeos da \#circulando • crédito da foto: arquivo ELC

Projetos como a videoinstalação \#Circulando são desenvolvidos em ciclos que podem ter sua duração variada. Neste caso específico, o trabalho desenvolvido com esta videoinstalação durou 6 meses. Por trabalhar com editais 
de patrocínio anuais, a escola planeja e organiza suas atividades para o período de um ano, trabalhando com vários projetos (ou poucos).

A ELC é considerada a primeira escola de cinema e audiovisual da Baixada Fluminense, começou a funcionar na cidade de Nova Iguaçu no ano de 2006 e assume como objetivos centrais estimular o encorajamento estético e a produção audiovisual através do contato com o fazer cinema. Proporcionar formas dos alunos e mediadores experimentarem o cinema se faz peça chave no trabalho da escola. Através disso os alunos passam a ter contato com as técnicas e linguagem que envolvem o processo de criação da imagem. As turmas da ELC têm em média 20 alunos cada e em 2014 as aulas de videoarte aconteceram em 4 turmas distribuídas ao longo da semana, com dois dias de aula cada, onde semanalmente novos alunos entraram e alguns saíram. Observando esse fluxo eu imaginava que qualquer atividade continuada fosse difícil de ser desenvolvida, mas essa não parecia ser uma preocupação para os mediadores, que já estavam acostumados com a dinâmica. Dia a dia as atividades eram desenvolvidas sem um tipo de preparação rígida que viesse a atrapalhar algo tão essencial para esse tipo de prática cinematográfica: a existência de uma experiência de criação.

Sobre a dimensão da experiência e o encontro com o cinema, dialogo com o pensamento de Bergala (2008) que afirma que na escola “[...] a arte não se ensina, mas se encontra, se experimenta, se transmite por outras vias além do discurso do saber, e às vezes mesmo sem qualquer discurso" (p. 31). É neste sentido que esta tese vai buscar na experiência de ensino da linguagem cinematográfica (em um ambiente de educação não formal) as marcas do gesto de criação, os questionamentos acerca da imagem, considerando que neste momento encontramos os "mecanismos subjetivos que produzem a arte em estado bruto", conforme afirma Duchamp (1986, p. 2) sobre o processo de criação na arte. Dessa forma, torno-me também, assim como alunos e os mediadores, uma espectadora que vivencia as emoções inerentes a esse processo de criação. Criação que carrega esforços, satisfações, recusas, decisões e que em meio a isso, procura fazer da experiência sua principal finalidade. E sobre isto podemos pensar que

A história do cinema traz a riqueza de acolher os processos criativos e subjetivo mais extravagantes. Circular por essa história é transitar entre nomes de realizadores, países e escolas que se cristalizam, mas é, antes de tudo, inventar para si, para aquele que deseja o cinema como forma de criação e descoberta 
do mundo, um tracejar momentâneo entre tantas linhas possíveis, entre tantos gestos que, por vezes encobertos por histórias hegemônicas, apresentam-se ávidos a serem renovados, reinventados (MIGLIORIN, 2014b, p. 157).

Conheci a Escola Livre de Cinema de Nova Iguaçu em 2013, através dos seus vídeos postados no Youtube, na lista de vídeos apresentada de forma aleatória chamou-me atenção títulos como "Quero ser Martin Arnold”, "Quero ser um viral", "Quero ser Andy Warhol”, "Quero ser um chroma key”, "Quero ser um making off'. O conteúdo apresentava o processo de criação de uma videoinstalação que seria lançada pela escola em poucas semanas. Nestes vídeos, assim como na arte contemporânea e nos trabalhos da videoarte, o material do processo de criação ganhava destaque, evidenciando o papel da experiência (e dos experimentos com a linguagem) durante o fazer cinema. A partir deste contato inicial, as primeiras questões começaram a se desenhar. Tratava-se de indagações sobre como seria a experiência de uma escola livre de cinema no contexto contemporâneo de produção. Considerando esta como uma escola que funciona através de editais e de forma colaborativa e em rede, quais seriam as formas que condicionam esse tipo de produção? Quais as singularidades de um processo quando o cinema se faz constituidor de uma experiência pedagógica?

\subsection{Criação cinematográfica, processos de criação, oficinas e contextos de formação: um breve panorama}

As discussões que envolvem o cinema e a educação no Brasil estão pautadas, em sua grande maioria, nos debates sobre o uso do cinema na escola, ou seja, dentro do ambiente da escola regular e abordam as possibilidades dessa tornar-se um espaço de encontro com o cinema. Secundariamente aparecem os debates sobre os contextos de formação e produção em oficinas (nas escolas, hospitais e outros contextos).

Nos últimos anos, com a intensificação dos debates em torno deste tema e o crescente interesse de pesquisadores na área, desenvolveram-se no Brasil importantes encontros e fóruns discussão como o Fórum da Rede Kino: Rede Latino-americana de Educação, Cinema e Audiovisual; o Programa Alfabetização 
Audiovisual - PAA e o seminário temático Cinema e Educação, que teve seu primeiro ano de funcionamento em 2016, no XX Encontro da Sociedade Brasileira de Estudos de Cinema e Audiovisual (SOCINE/2016). Além destes encontros, inúmeras pesquisas são desenvolvidas no âmbito dos grupos de pesquisa vinculados às linhas pesquisas dentro da pós-graduação do país: GRUPEM - Grupo de pesquisa em educação e mídia (PUC-Rio); o Laboratório de Educação, cinema e audiovisual e o CINEAD - Cinema para aprender e desaprender (UFRJ); Núcleo Infância, Comunicação, cultura e arte - NICA (UFSC); Aruanda lab.doc - Pesquisa e análise sobre métodos de produção de audiovisual de não-fiçãa (USP); Kumã: Laboratório de pesquisa e experimentação e imagem e som; Pontão de Cultura Digital (ECO/UFRJ); Grupo de pesquisa em semiótica e culturas da comunicação (UFRGS); GEIN - Grupo de Estudos em Educação Infantil (UFRGS); e LINCE - Linguagens, Infância e educação (UNISC), dentre outros ${ }^{7}$.

A título de amostragem, um levantamento realizado entre os trabalhos apresentados no seminário temático "cinema e educação" do XX Encontro da Sociedade Brasileira de Estudos de Cinema e Audiovisual (SOCINE/2016), foi possível perceber que as discussões que envolvem o binômio cinema e educação se intensificaram a partir de 2014, com a implantação da Lei № 13.006 (de 26 de junho de 2014), que estabelece a obrigatoriedade da exibição de filmes de produção nacional nas escolas de educação básica por, no mínimo, 2 horas mensais. Muitos pesquisadores começaram a pensar as várias formas de como essa Lei poderia efetivamente funcionar no ambiente escolar. Algumas das ações nessa área recuperam a perspectiva institucional, buscando assegurar a inserção de filmes no currículo escolar; outras privilegiam a formação estética, no intuito de qualificar o olhar do espectador para o potencial artístico da linguagem audiovisual. Algumas ações têm como foco a formação política, configurando-se como estratégia de empoderamento de comunidades e de grupos sociais em luta por direitos e/ou em situação de risco.

Dimensionando ainda a importância de um levantamento sistematizado sobre o cenário das pesquisas de doutorado no Brasil, busquei inicialmente o Banco de Teses da Coordenação de Aperfeiçoamento de Pessoal de Nível

\footnotetext{
${ }^{7}$ Esta lista de grupos encontra-se disponível em DUARTE; GONÇALVES (2014, p. 18)
} 
Superior (Capes), sistema que se propõe a abrigar a lista de todas as teses e dissertações produzidas na pós-graduação brasileira. Esse sistema, porém, apresentou limitações na disponibilização dos dados a que se propõe, dificultando a realização de uma pesquisa mais detalhada, pois com a implantação de uma nova plataforma, desde o início de 2014 o banco de dados retirou do seu sistema a opção de busca avançada, por combinação de palavras-chave e com opções para escolha dos campos de busca (por palavras-chaves combinadas e termos, por exemplo). Por entender que esse panorama não se aproxima do quadro real e especialmente pela inviabilidade de trabalhar com a quantidade de registros gerados (sem filtro), optei por complementar este levantamento por meio do banco de dados da Mnemocine (http://www.mnemocine.com.br/), uma publicação eletrônica de conteúdo técnico e didático sobre o universo audiovisual, comumente utilizada em pesquisas acadêmicas no país.

Através da manipulação desses dados, procuro apresentar a seguir, em que medida o interesse acadêmico por esse tipo de produção cinematográfica tem se desdobrado em pesquisas de doutorado.

Iniciei a busca com um conjunto de palavras-chave, especialmente as que envolvem este trabalho. Dessa forma, procurei a associar a palavra "cinema" a um conjunto de palavras evidenciadas nesta pesquisa, tais como "processo de criação", "criação cinematográfica" e "oficina". Após agrupar os trabalhos, procurei identificar a temática de cada pesquisa, inicialmente através do título dos trabalhos e depois pela leitura dos resumos e palavras-chave. As imagens 3 e 4 apresentam o universo de palavras que envolve os critérios de busca, com este primeiro exercício, obtido através das palavras-chave utilizadas nas teses, tive a dimensão do que estava mais próximo de cada campo. A primeira constatação é de que as pesquisas estão mais próximas ao campo da educação, em seguida aparecem os campos da comunicação e letras. 


\begin{tabular}{|c|c|}
\hline \multirow{2}{*}{ TERMOS DE PESQUISA } & QUANTIDADE DE OCORRÊNCIAS \\
\cline { 2 - 2 } & Teses \\
\hline cinema; processo de criação & 4 \\
\hline cinema; criação cinematográfica & 6 \\
\hline Cinema; oficina & 12 \\
\hline Total de ocorrências & 20 \\
\hline
\end{tabular}

Tabela 1 - Quantidade de teses encontradas por termos de pesquisa
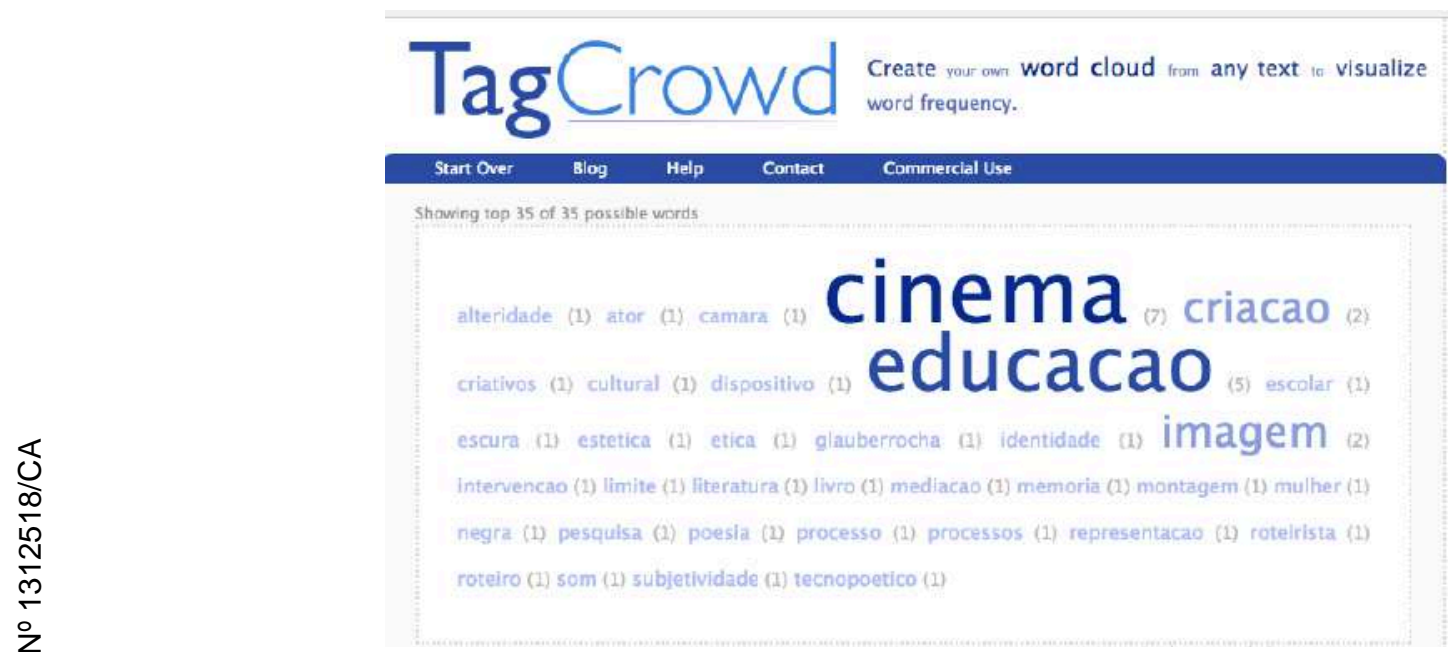

Imagem 3 - Universo de palavras associadas ao termo "processo de criação cinematográfica"

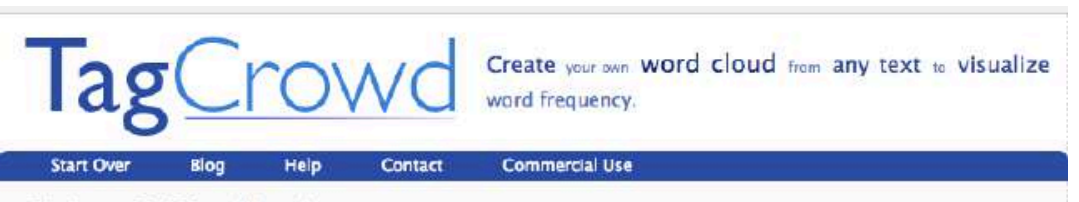

Showing top 58 of 58 passibie words

aldelas (1) ambiental (1) amblente (1) antropologia (1) arte (1)

\section{audiovisual}

\section{cinema}

cognicao (1) comunicacas (1) continuada (1) convencionais (1) cotidiano (1) criativos (1) democratica (1) dialogica (1) documentario (2) educacao (4) ensino-aprendizagem (2) ensino (2) escola (1) estetica (3) etica (1) experiencia (1) famillas (1) filmica (1) formacaO (3) inclusao (1) incorporadas (1) indigenas (1) internet (1) Jovens (1) Iinguagem (1) fiteratura (1) marginal (1) modelos (1) nao (1) narrativas (1) Oficinas (2) organizadas (1) pegadogia (1) percepcao (1) periferia (2) politica (2) primardias (1) processos (1) producao (2) professores (2) publica (1) reconhecimento (1) saude (1) videa (1) videoprocesso (1) 
Diante do levantamento feito, percebi que grande parte das pesquisas que problematizam a relação do cinema com seu processo de criação tem como objetivo de pesquisa a análise de produções do campo do documentário (quando o trabalho está no campo da comunicação, artes ou artes visuais) e trabalham seus objetos a partir da análise fílmica de obras que abordam a periferia como temática. Tais trabalhos mantêm seu foco especialmente nas questões que envolvem a representação desses locais pelo cinema. A ênfase na problematização do uso do cinema em sala de aula, ganha força como questão de pesquisa quando o trabalho está vinculado a um programa de pós-graduação em educação. Observei também a existência de trabalhos cuja proposta é uma leitura comparada entre processos de criação cinematográficos e da literatura, que são analisados sob a ótica dos estudos da Crítica Genética, vertente ligada à linguística e à crítica literária que entende o processo criativo a partir do conceito de redes de criação.

Ressalto ainda que é justamente quando utilizamos a palavra "oficina" como termo de busca que se obtém um maior número de pesquisas que se debruçam na leitura de projetos com oficinas de audiovisual e trabalham com o processo de criação.

No que se refere aos procedimentos metodológicos, os relatos feitos por Zanetti (2010) e SILVA (2011) por exemplo, abrem um espaço para pensar os procedimentos multidisciplinares como forma de abordar experiências cinematográficas a partir dos seus processos de criação. É recorrente o uso da etnografia como inspiração metodológica em certos procedimentos que são feitos como forma de acompanhar as experiências cinematográficas em sets de filmagem ou oficinas de formação. A recorrência maior se dá no uso de entrevista e, por vezes, na observação participante como ferramentas.

Destaco ainda que no âmbito das pesquisas acadêmicas é possível encontrar referências à Escola Livre de Cinema de Nova Iguaçu em duas pesquisas de mestrado: Novas telas, novos olhares: audiovisual e inclusão subjetiva na Escola Livre de Cinema de Nova Iguaçu, apresentada por Tereza Cristina Fazolo Freire (2012), que aborda a escola como estudo de caso e apresenta uma discussão sobre os processos de inclusão, por meio da análise do impacto de suas atividades e bens culturais. A pesquisa intitulada A Escola Livre de Cinema de Nova Iguaçu: educação, cultura e política para jovens da Baixada 
Fluminense, de Mônica da Silva Francisco (2015), traça um diálogo entre o cinema, a arte e a educação, numa proposta que aborda os aspectos relacionados à temática da educação e juventude.

\subsection{Percursos metodológicos}

\subsubsection{Escolhas e aproximação}

Ao escrever o projeto de pesquisa para o doutorado e me deparar com a possibilidade de investir quatro anos em pesquisa e estudo sobre o cinema, inevitavelmente pensei no processo de criação da imagem cinematográfica. $O$ encanto por este "ambiente" teve início em minha experiência profissional no departamento de criação e arte das agências de publicidade em que trabalhei ${ }^{8}$ e nos catálogos de filmes e mostras que sempre me fascinaram, especialmente quando traziam em suas páginas relatos do processo de criação e produção. Durante o trabalho nas agências percebi que o momento da criação imagética é sempre permeado de escolhas e negociações, discutimos com clientes na tentativa de transformar nossas ideias em uma imagem, apostando que aquilo seja o que o produto necessita.

No cinema as negociações durante o processo de produção são também de natureza política. Escolhas estão postas enquanto motivações, circunstâncias e o acaso movem o trabalho de criação. Assim sendo, diante da possibilidade de ver as imagens cinematográficas emergirem e observar o funcionamento do fazer cinema de perto, decidi que esse seria o meio pelo qual eu adentraria nos estudos cinematográficos e que este seria o lugar de onde a empiria desta pesquisa tomaria forma. Estudar o processo de criação é, como defende Salles (2008), fazer leituras do inacabado, perceber mutações, mobilidades, movimentos e continuidades.

Assim, em 2012, durante o processo de escrita e em busca de produções cinematográficas em desenvolvimento conheci a ELC. As informações iniciais foram obtidas pela internet, nos textos feitos pela ELC em seu blog e site, nos

\footnotetext{
${ }^{8}$ Embora considere que a criação publicitária e a criação cinematográfica estão em esferas distintas e que a possibilidade de interseção entre as duas é improvável, citei a prática publicitária para falar de minha experiência, que embora não se relacione diretamente com o cinema,, promoveu uma aproximação pessoal com ele.
} 
vídeos postados em seu canal do Youtube e também pela página do Facebook, usada para divulgar o desenvolvimento de suas atividades. Percebi que a escola desenvolvia projetos periódicos, divulgando-os ao fim do semestre letivo e foi justamente essa periodicidade que, inicialmente, me fez acreditar ser possível desenvolver uma investigação do processo de criação do começo ao fim (ou seja, do início de uma oficina ou ciclo ao lançamento de uma obra).

Investigar a experiência de uma escola de cinema configurou-se como um deslocamento dentro da minha própria prática, encarando o processo de criação de uma forma nova, atentando para as especificidades de uma prática que embora não seja desconhecida por mim, de certa forma, permitiu que eu experimentasse um "estranhamento" dentro desse ambiente, algo como um olhar estrangeiro em busca de significados, como defende Travancas (2009, p. 100).

O encontro com o cinema da ELC desencadeou uma série de outros encontros, que podem ser vistos ao longo do texto desta tese. São deslocamentos que me fizeram cortar a cidade e parte do estado do Rio de Janeiro, assim como atravessar o Oceano Atlântico.

Ainda durante o processo de escrita do projeto de tese cursei uma disciplina como aluna ouvinte no Programa de Pós-graduação em Comunicação (PPGCOM) da Universidade Federal Fluminense (UFF). O cenário dos cursos de pósgraduação do Rio de Janeiro naquela época (meados de 2012) proporcionava a circulação dos pós-graduandos pelos diversos programas em comunicação, experiência que para mim, se mostrou extremamente positiva, por propiciar o diálogo com vários pesquisadores e a constante troca de ideias. Foi enquanto cursava a disciplina "Cinema com Deleuze" que conheci alguns alunos que estavam envolvidos com a ELC através do Kumã (Laboratório de pesquisa e experimentação em imagem e som da UFF), que desenvolvia uma parceria com a escola naquela época. Uma dupla de alunos do curso de cinema de vídeo daquela universidade atuava em uma das turmas da ELC ministrando oficinas e conferindo suporte metodológico à escola. No ano seguinte (meados de abril de 2013) visitei a escola a convite de um colega e professor departamento de Cinema da UFF, essa visita colocou-me em contato com a ELC e também com o território, visitei o

\footnotetext{
${ }^{9}$ A disciplina foi ministrada pelo professor Cezar Migliorin durante o segundo semestre de 2012, na UFF.
} 
bairro de Austin pela primeira vez, cortando a Baixada Fluminense pelos ramais da SuperVia (concessionária responsável pelo sistema de trens da região metropolitana do Rio de Janeiro, tão famosa pelos problemas em seu funcionamento).

Austin é um bairro polifônico. Os sons dos carros, buzinas e motos, do altofalante e das pessoas no comércio se misturam a cada segundo. Naquela vista à ELC fui apresentada à coordenação como pesquisadora interessada na experiência da escola. A recepção foi amigável e, de certa forma, a escola pareceu-me aberta a esse tipo de trabalho, embora tivesse críticas aos trabalhos de pesquisa acadêmicas por relatar que, ao fim da pesquisa, a escola raramente tem um retorno, ou toma conhecimento do trabalho finalizado.

Depois daquela visita, outra aconteceu durante o mês de junho de 2013, quando estava sendo exibida a videoinstalação \#QueroSer, na sede da escola. Desta vez fiz a visita sozinha e optei por não me identificar como pesquisadora. Naquele dia eu estava ali, como os demais visitantes, para contemplar a videoinstalação. Assisti aos vídeos, \#QueroSerAndyWarhol, \#QueroSerLygiaPape, \#QueroSerEmmaBenany e \#QueroSerPeterCampus na exposição e esse foi meu primeiro contato com a produção da ELC in loco. O trajeto ainda era novo para mim, mas percorrê-lo sozinha me fez rememorar imagens que antes eu já havia explorado nos vídeos da escola.

Austin é um dos bairros mais afastados do centro de Nova Iguaçu, talvez por isso sua localização seja por vezes associada a outra cidade. $\mathrm{O}$ ramal de trem para Japeri (cidade próxima a Austin) corta o bairro em dois e os trilhos do trem marcam também o imaginário do local. Tudo acontece em torno da estação de trem e ao longo da passarela que liga a estação ao centro comercial do bairro: o principal ponto de mototáxi fica ali, assim como as barracas de frutas, verduras, carnes e peixes, relógios, roupas usadas e panelas. Chegar à escola é fácil: subindo a passarela da estação de trem e olhando para o lado direito é possível ver a placa da escola na fachada vermelha.

Depois do contato inicial e já cursando o doutorado pela Pontifícia Universidade Católica do Rio de Janeiro (PUC-Rio), procurei a coordenação da escola via e-mail, agendei uma conversa com a produtora da ELC e em outubro de 2013 fui até Austin novamente, dessa vez para conversar sobre a escola, sua 
estrutura, objetivos e funcionamento. Foi a partir dessa conversa que comecei a visualizar os desafios que eu teria ao optar pelo tipo de exploração que planejava.

Em meio ao processo inicial do levantamento bibliográfico das pesquisas desenvolvidas sobre o processo de criação e usando assim as indicações feitas por Fonseca (1999) e Travancas (2009) em seus textos sobre a pesquisa empírica, comecei reunindo informações sobre a escola, procurando entender sua estrutura, seus objetivos e trabalho. Neste sentido, as conversas com a produtora trouxeramme dados preliminares para uma cartografia da escola.

É bom começar com as coisas concretas, relações de alguma forma institucionalizadas. Assim, estabelecemos listas sobre "dados básicos" [...] Procuramos entender quem é ligado a quem, por que tipo de vínculo; com estes dados, formulamos tabelas, desenhamos casas, projetamos diagramas e cruzamos variáveis. (FONSECA, 1999, p. 68)

Durante o período inicial concentrei meus esforços na experimentação, ou seja, procurei me familiarizar com as alternativas de produção da empiria, assim como as vantagens e desvantagens dos diferentes ângulos de observação que eu pudesse escolher para abordar a experiência da escola. Concordando com o que defende Brandão (2002):

Isso não se aprende senão pela prática pois, através dela enfrentam-se situações que permitem e, algumas vezes, obrigam a experimentar correções, ajustamentos e alternativas acompanhadas de reformulações conceituais, as quais gradativamente estruturam o modus aperandi científico" (p. 31).

Outro encontro aconteceu no mês seguinte, em novembro de 2013, quando conversamos mais especificamente sobre os horários das turmas e a melhor maneira de acompanhá-las. Nesta mesma ocasião, aproveitei para assistir a uma aula que estava sendo ministrada por um dos mediadores das turma de videoarte e ali pude ver a dinâmica desenvolvida. Durante essas duas visitas (outubro e novembro de 2013) procurei fazer uso das ferramentas metodológicas, mas consciente de que essa fase serviria como um experimento, uma aproximação. Acompanhei as conversas com a produtora e o mediador da escola fazendo o uso convencional de um bloco de anotações e, ao retornar para casa, preparei um pequeno relato, evidenciando aspectos institucionais da escola e sobre o seu 
funcionamento. Por não conhecer a escola e seu trabalho anteriormente, esse período de aproximação foi de fundamental importância.

A ELC trabalhava com 4 turmas de videoarte, cada uma delas funcionando com duas aulas semanais distribuídas entre os turnos da manhã e tarde. Devido às outras atribuições com as quais eu estava envolvida na PUC-Rio (como estágio de docência e cursando disciplinas obrigatórias) o tempo disponível e distância a ser percorrida entre a minha casa, a ELC e a PUC-Rio (em média $92 \mathrm{~km}$, cortando 3 zonas extremas da cidade por meio do transporte público do Rio de Janeiro), optei por acompanhar a turma $\mathrm{C}$, assistindo às aulas de quarta e sexta, das $9 \mathrm{~h}$ às $11 \mathrm{~h}$. A imagem daquele momento que segue emblemática para mim é uma reprodução do panfleto distribuído pelas ruas de Austin com a chamada para a turma de videoarte daquele ano.

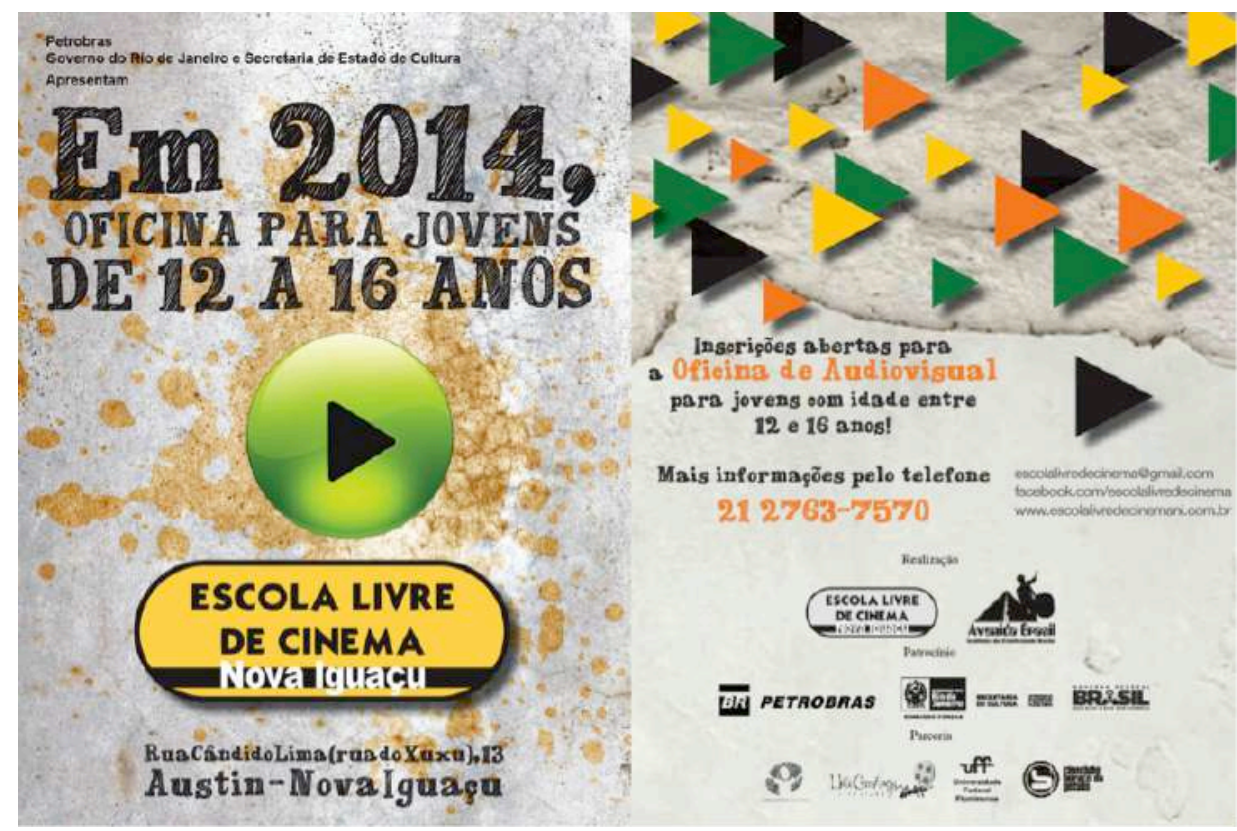

Imagem 5 - Planfleto de divulgação da turma de videoarte 2014 - créditos: ELC

\subsubsection{Notas sobre a escolha pelo processo de criação}

Um filme em vários atos. Penso no processo de criação a partir da origem da palavra "ato" ${ }^{10 "}$ - derivada do latim actus: movimento, impulso - para lançar o olhar sobre um processo em desenvolvimento, onde as escolhas, negociações e

10 "ato", in Dicionário Priberam da Língua Portuguesa, 2008 2013, http://www.priberam.pt/DLPO/ato [consultado em 03-02-2015]. 
necessidades estão postas. Essas necessidades movem o nascimento da ideia e permeiam o processo de criação, dessa forma, concordo com o que pensou Deleuze $^{11}$ ao afirmar que ninguém tem uma ideia sem que seja preciso, sem que haja necessidade. Segundo o filósofo, “um criador não é um ser que trabalha pelo prazer. Um criador só faz aquilo de que tem absoluta necessidade” (DELEUZE, 1999, p. 3). Sendo assim, as questões suscitadas durante o processo de pesquisa desta tese surgem desse momento, o que por muitas vezes se configurou como um fator complicador, pois somente após a construção da empiria, ou seja, após a pesquisa de campo, passei a perceber suas questões de forma mais articulada.

O processo descrito aqui tem como objetivo expor de forma sistemática os bastidores da pesquisa de campo feita durante o ano letivo de 2014 na ELC, cujo ciclo teve como produto final do trabalho desenvolvido, a videodança Montão de Coisa, lançada em novembro de 2014. O processo de criação do vídeo é tomado como objeto empírico para discutir as questões expostas ao longo do texto.

O acompanhamento dessa experiência de criação deu-se entre os meses de fevereiro a novembro de 2014. Posso dizer que minha entrada no campo foi marcada por inspirações etnográficas e, desse modo, assisti às aulas de uma das quatro turmas de videoarte na sede da escola, duas vezes por semana. Preliminarmente, a construção do método, ou melhor, as indicações de como proceder durante essa etapa foram inspiradas nos apontamentos feitos por Alain Bergala, no livro A Hipótese-cinema - pequeno tratado de transmissão do cinema dentro e fora da escola (2008), especialmente pela sua escolha em voltar ao momento da criação cinematográfica e do texto publicado por Isabel Travancas, Fazendo etnografia no mundo da comunicação (2009), onde autora com base no pensamento de Geertz apresenta a metodologia aplicada à área da comunicação.

Sobre as proposições de Bergala (2008) é importante enfatizar que o autor trabalha a análise da criação como método de abordagem do cinema nas escolas. Suas colocações são feitas com o objetivo de fazer com que professores e mediadores trabalhem o cinema a partir do processo criativo que envolveu as obras cinematográficas. Suas indicações inspiram este trabalho na medida em que o autor ocupou-se de pensar os componentes fundamentais do gesto de criação

11 Palestra proferida em 17 de marco de 1987 disponível on-line em: https://www.youtube.com/watch?v=VNKo53tUKb4. Texto publicado na Folha de São Paulo, 27 de junho de 1999. 
cinematográfica e as condições da tomada de decisão pelo cineasta. Mas é oportuno pontuar que o objetivo de Bergala em seu relato é compartilhar a experiência de voltar ao ato de criação a partir de uma obra finalizada, como os exemplos usados sobre os filmes de Robert Bresson e Dreyer. Já nesta pesquisa, o ponto de partida é a própria experiência de criação in loco e com isso faz-se necessário lidar com um processo inacabado, até que se chegue ao final da produção.

Com base no texto de Travancas (2009), pude esquematizar o uso de ferramentas que auxiliassem na produção da empiria. Dessa forma, acompanhei as aulas fazendo anotações em um caderno de campo, em cujas notas encontro dúvidas, ideias, palavras-chave e um resumo das atividades feitas em cada encontro. Esse material por vezes é complementado por fotos e vídeos que após serem catalogados se configuraram como uma espécie de diário dos encontros. Devido ao volume de material (imagens, fotos e áudios), criei uma espécie de "biblioteca digital", organizando tudo por data e com etiquetas que ajudam a otimizar a busca dos arquivos por tipo de atividade (por exemplo, "exercício", "aula teórica", "gravação externa" etc). O material empírico também é composto, de forma complementar, por diário de aulas, imagens e vídeos gravados e organizados pelos mediadores da ELC durante as aulas. Cataloguei esse material por entender que se trata de elementos que auxiliam na rememoração das etapas do processo, no entanto, é importante deixar claro que os diários de aula não foram analisados com a intenção de que se tornassem "validadores do discurso proferido", uma vez que esta pesquisa não se propõe a esta finalidade. Ao contrário, eles me ofereceram elementos outros na construção do diálogo com a empiria.

Toda organização do material foi feita em uma plataforma digital, funcionando - como já mencionado - como uma espécie de diário ou blog, disponível online ${ }^{12}$ e protegido por senha. Sua existência otimizou o trabalho de pesquisa, especialmente quando foi preciso trabalhar na tese de forma compartilhada com meus orientadores, no Brasil e Itália.

12 Conteúdo disponível em https://www.tumblr.com/blog auth/processoelc, senha para acesso: "Austin" (com A maiúsculo). 


\subsubsection{Cartografar é preciso: sobre a construção da empiria}

[...] o mapa das associações que compõem o mundo social é desenhado se seguirmos as marcas feitas pelos atores (LATOUR, 2012, p. 13).

A cartografia aparece nesta tese especialmente em dois momentos: inicialmente para mapear os 10 anos da ELC, procurando entender sua filiação no contexto de produção atual e visualizar os rizomas que permeiam sua filosofia de trabalho. Em seguida, ela aparece como ferramenta importante no trabalho de organização da empiria, evidenciando as práticas que compõem o processo em que o cinema e o audiovisual são o elã, auxiliando no mapeamento das etapas de criação e na preparação do material empírico para o trabalho de análise ${ }^{13}$.

Ao longo do percurso do doutorado tive contato com autores que trouxeram contribuições importantes para pensar a pesquisa e as possibilidades de desenvolver este trabalho. Nesse contexto a cartografia aparece como ferramenta para auxiliar não só a sistematização do material coletado ao longo de um ano dentro da ELC, mas também como "um guia de viagem” (LATOUR, 2012) estratégico, pois, nesse itinerário, o que ocorreu foi a realização de uma pesquisa enquanto os fenômenos relacionados a ela ainda estavam acontecendo. Neste sentido, aparece com referência às proposições feitas por Bruno Latour, com a cartografia de controvérsia, particularmente suas indicações iniciais de uso, como ferramenta. As escolhas de como trabalhar a empiria desta tese só nasceram após o final do trabalho de campo.

Latour trabalha com uma interpretação da ANT (Actor-network Theory), também conhecida como TAR (Teoria do Ator-rede), este tipo de cartografia pode ser entendida como um conjunto de técnicas para explorar e visualizar problemas (questões) em torno do social e também de questões tecnocientíficas, onde para o autor é imprescindível seguir os atores e observar suas associações. Estas ações iniciais do pesquisador diante dos atores em ação são exploradas por Tommaso Venturini no texto "Diving in Magma" (2010), que se propõe a documentar o uso da cartografia de controvérsias como método de pesquisa. No texto, o autor,

\footnotetext{
13 Os capítulos 3 e 4 apresentam e analisam da empiria da tese.
} 
seguindo os pressupostos de Latour, enfatiza que é preciso "somente observar" (a ênfase ao nome "somente" é dada pela necessidade de que a observação inicial seja feita sem que se aplique uma teoria e método antecipadamente). Para os defensores deste método, isso faz com que o pesquisador não caia no erro de atribuir aos atores o papel de meros informantes.

As cartografias organizadas ao longo da tese foram organizadas com base nos dados informados pela ELC nos seus canais de divulgação, como site institucional $^{14}$, página do facebook ${ }^{15}$, folders das três últimas produções da escola: as videoinstalações \#QueroSer (2013) e \#Circulando (2014) e a exibição da videodança Montão de Coisa (2014), e duas entrevistas abertas concedidas pela produtora da escola, Luana Pinheiro.

O uso da entrevista ajudou a sistematizar as informações sobre a ELC e especialmente a entender a rede que se articula para sustentar a escola institucional e financeiramente. Durante o processo de aproximação, antes do trabalho de campo, conversamos, na $1^{\text {a }}$ entrevista, sobre os projetos da ELC e sempre em meio a isso, ouvi repetidas vezes os nomes dos parceiros da escola. A segunda entrevista foi em de 04 de maio de 2015 (depois de concluídas as observações das aulas no trabalho de campo). Ambas foram abertas, ou seja, procurei deixar a produtora à vontade para falar sobre a estrutura institucional da escola, através de um relato sobre a história da instituição.

No que tange à estrutura organizacional da escola, percebemos que ela se caracteriza pelas parcerias articuladas. A ELC nasceu a partir da proposta de oficinas de cinema e audiovisual elaborada pelo escritor, diretor e produtor cultural, Marcus Faustini, a convite do então prefeito da cidade de Nova Iguaçu, Lindberg Farias, que na época estava implantando um novo projeto de educação na cidade, chamado Bairro Escola. Sobre a sua forma de trabalhar, a escola assume uma metodologia que articula três conceitos - palavra, corpo e território, como elementos de expressão da imagem e do som através de ações artísticas dentro e fora da sala de aula ${ }^{16}$. Seu conteúdo pedagógico aponta para o domínio das técnicas e para o encorajamento estético, no sentido de estimular a criação e a

\footnotetext{
$14 \mathrm{O}$ site institucional, In: http://escolalivredecinemani.com.br/ 15 A página do facebook da ELC funciona com uma agenda, onde são divulgadas as atividades, ações e making offs das atividades desenvolvidas: In: https://www.facebook.com/escolalivredecinema 16 A metodologia da ELC será discutida no capítulo 4.
} 
produção audiovisual. Este cenário de ações e de representatividade para o pensamento da educação por meio do audiovisual é proveniente de um histórico de vivências, de estratégias, de catalogação de imagens e de experimentação no território.

As oficinas criadas por Faustini aconteceram inicialmente no espaço escolar da rede municipal, no bairro de Miguel Couto, na cidade de Nova Iguaçu, durante o contraturno das aulas e envolvia essencialmente crianças e adolescentes. Programas como esses, que resultaram na criação da ELC, são frutos das mudanças políticas, combinadas a novas formas de mobilização social que surgiram no Brasil a partir dos anos 2000.

Essas mudanças políticas, combinadas a novas formas de mobilização social, refletiram-se nos programas culturais e educativos e levaram o audiovisual para dentro de comunidades mais pobres, com os recursos públicos sendo distribuídos, prioritariamente, a organizações do terceiro setor ou da sociedade civil: ONGs, OSCIPSs e cineclubes (DUARTE E GONÇALVES, 2014, p. 41).

Um dos desafios iniciais do projeto era transformar o território em histórias para o cinema, valorizando as potências locais e seus atores. Desta forma, as crianças tiveram contato com as técnicas do documentário e animação. Foi por meio dessas linguagens que apresentaram Miguel Couto sob seus diversos olhares.

Em 2007 a OSCIP $^{17}$ Avenida Brasil Instituto de Criatividade Social, instituição criada por Faustini para gerir projetos como esse ${ }^{18}$, alugou um pequeno prédio também no bairro de Miguel Couto onde passou a funcionar uma turma de sábado para adultos, criada com o objetivo de ampliar o público da escola livre de cinema. Ainda no mesmo ano foi inaugurado o prédio sede da ELC, com estrutura de ilha de edição e sala de projeção. Para os que estavam envolvidos no processo,

\footnotetext{
${ }^{17}$ A sigla OSCIP significa Organização da Sociedade Civil de Interesse Público. Trata-se de uma qualificação jurídica dada a pessoas jurídicas de direito privado, sem fins lucrativos, instituídas por iniciativa de particulares, para desempenhar serviços sociais não exclusivos do Estado com incentivo e fiscalização do Poder Público, mediante vínculo jurídico instituído por meio de termo de parceria. (In: CARDOSO, Univaldo Coelho. OSCIP: organização da sociedade civil de interesse público. / Univaldo Coelho Cardoso, Vânia Lúcia Nogueira Carneiro, Édna Rabêlo Quirino Rodrigues. - Brasília : Sebrae, 2014).

${ }^{18}$ Avenida Brasil Instituto de Criatividade Social é uma ONG (Organização Não Governamental) que possui a qualificação de OSCIP, está localizada na cidade de Nova Iguaçu (RJ) e que trabalha principalmente na capacitação de crianças e jovens na área do audiovisual.
} 
esse foi o primeiro grande salto da escola. Luana Pinheiro relata que é nesse momento que a escola começa a desenvolver sua própria metodologia, o momento anterior é considerado um período de experimentação.

Em um breve espaço de tempo a ELC saiu do ambiente escolar formal (ou seja, das escolas municipais de Nova Iguaçu) e se estabeleceu em sua própria sede, demarcando esse território como instituição de educação não formal. Quanto às suas atividades, a escola que começou em 2006 com aulas de audiovisual para crianças no contraturno da escola formal, trabalhando com oficinas práticas de audiovisual, logo se expandiu e passou a ter oficinas mais elaboradas em 2007, com a participação de grandes nomes do cinema e audiovisual atuando em etapas específicas da produção cinematográfica, do roteiro à edição. Passaram pela ELC nessa época nomes como, Dib Lutfi, Walter Goulart, Antonio Molina, etc. Todos foram convidados por Faustini, pois havia entre eles relações de proximidade que favoreceram a parceria então estabelecida.

Durante todo seu funcionamento a escola permaneceu sendo gerida pela OSCIP Avenida Brasil e em pouco tempo foram propostas alternativas de capacitação de alunos para atuarem na própria escola, seja como produtores ou mediadores. Surgiram assim as turmas no turno da noite, que trabalhavam com a capacitação em audiovisual e eram voltadas para jovens e adultos. Outra ação da escola em seu momento inicial foi a sua "pulverização" pelos bairros de Nova Iguaçu, com a criação de núcleos de audiovisual em bairros como Austin, Cabuçu e Jardim Tropical. Era comum que, nessa época, os alunos tivessem aula à noite durante a semana e no fim de semana atuassem nos núcleos. Enquanto isso, a turma para crianças e adolescentes continuava em atividade durante toda semana.

Com objetivos mais claros e uma metodologia de trabalho em desenvolvimento, os alunos do projeto bairro escola começaram, ainda em 2007, a trabalhar na criação de um personagem chamado "Iguaçu", personagem principal da série animada "As aventuras de Iguaçu e sua turma" que, em 2008, ganha uma série de episódios que são lançados em DVD durante o I IGUACINE, $1^{\circ}$ Festival de Cinema da Cidade de Nova Iguaçu, também organizado pela ELC.

Ao observar a produção da escola de 2008 a 2011, percebe-se a articulação de muitas atividades envolvendo a estrutura da ELC. Só durante esse período houve a organização de duas edições do Festival IGUACINE (2008 e 2009). A escola produziu algumas vinhetas em homenagem aos Jogos Pan-Americanos de 
2007 que foram veiculadas na Rede Globo, maior canal de TV aberta do país. Em 2009 fechou uma parceria com a Escola de Comunicação da Universidade Federal do Rio de Janeiro (ECO/UFRJ) e esta foi a primeira experiência de parceria com a academia. A turma de alunos deste projeto era formada por ex-alunos da ELC que tinham aulas com dois professores da ECO/UFRJ. Ao final de 4 meses de aula os alunos deveriam pensar em um projeto, que seria avaliado por uma banca. $\mathrm{O}$ projeto vencedor foi contemplado com um valor em dinheiro. Essa foi mais uma ação da ELC feita diretamente para ex-alunos. "Eu lembro que quem ganhou, foi o Alexandre, ele hoje trabalha no Observatório de Favelas, outro que saiu da escola e foi voar", relata Luana Pinheiro.

As turmas de 2010 trabalharam com videoclipe, dublagem e documentário e em meio a essas aulas surgiu o processo dos Autorretratos, que é considerada a primeira aproximação da escola com o trabalho da videoarte. Até aquele ano a escola funcionava a todo vapor, experimentando o audiovisual e produzindo nas mais variadas formas. Porém, com as mudanças de governo e os cortes nos financiamentos, entre o final de 2011 e o começo de 2012 a escola enfrentou problemas tanto financeiros quanto com relação ao aluguel do prédio onde funcionava a sede de Miguel Couto. Foi o período em que a escola esteve praticamente fechada. Mas, na tentativa de mantê-la em atividade a coordenação articulou uma nova rede de parcerias.

A instituição passou a funcionar com uma gestão colaborativa entre a Universidade Federal Fluminense - UFF, a ONG Laboratório Cultural, o cineclube O Buraco do Getúlio e o cineclube Mate com Angu. A sede da escola mudou para o bairro de Austin, também em Nova Iguaçu, dividindo o prédio com a ONG Laboratório Cultural. Financeiramente a escola que se sustentava inicialmente como um programa da prefeitura de Nova Iguaçu, passou a ser Ponto de Cultura ${ }^{19}$ e recebeu um financiamento do Ministério da Cultura - MiC e da Petrobras, através da Lei do ICMS. Duarte e Gonçalves (2014, p. 43) comentam que fatos como esses, que aconteceram neste período na ELC, são característicos

\footnotetext{
19 Ponto de Cultura é uma entidade cultural ou coletivo cultural certificado pelo Ministério da Cultura, com o intuito de atuar em comunidades e territórios. Trata-se de uma política cultural que, ao ganhar escala e articulação com programas sociais do governo e de outros ministérios, pode partir da Cultura para fazer a disputa simbólica e econômica na base da sociedade. (Disponível em http://www.cultura.gov.br/pontos-de-cultura1. Acesso em 15 de novembro de 2016).
} 
de um tipo de política institucional que implica a associação público/privado. No contexto da tradição política do País, "são frequentemente interrompidos com as trocas de gestão e, apesar da relativa estabilidade do período, as parcerias estabelecidas nessa área podem vir a ser desfeitas".

No fim de 2012 e início de 2013 as turmas da semana (4 turmas distribuídas ao longo da semana, nos turnos da manhã e tarde), que eram fruto direto daquelas turmas do antigo projeto bairro escola, começaram a trabalhar com a videoarte. Este trabalho resultou na videoinstalação \#QueroSer e logo após, em um processo mais curto, as turmas do segundo semestre de 2013 tiveram como produto do seu processo a videoinstalação \#Circulando.

Sobre o retorno da ELC com a nova sede em Austin e o lançamento da \#QueroSer, Luana Pinheiro relata:

Foi muito legal, porque tanto Bion, Cleiton e eu participamos da história toda da escola e conseguimos "peneirar" tudo que tinha sido interessante e tudo que não tinha sido, para não repetir. E fizemos a \#QueroSer, que foi linda. Considero que voltamos com chave de ouro (Luana Pinheiro, entrevista do dia 04 de maio de 2015).

Em 2014, a ELC trabalhou com um calendário articulado ao da rede escolar em um ciclo de um ano, trabalhando com 4 turmas de crianças e jovens no projeto de videodança que deu origem ao vídeo "Montão de Coisa", neste ciclo recebeu o reforço de profissionais que nunca haviam trabalhado ou estudado na escola e, no segundo semestre do mesmo ano, formou uma turma.

Já em 2015 experimentou outros formatos no universo da videoarte e da dança, com projetos mais curtos e com uma maior quantidade de vídeos finalizados ("Quadradinho de 8" e "Fanque-me", produzidos pelos alunos da Oficina Dança e Filma), ainda no mesmo ano organizaram um cineclube dentro da escola e a $4^{\text {a }}$ edição do Iguacine, festival que envolveu diversos projetos, como Oficina de Produção de Festivais, que formou os organizadores e a Oficina Palavra-Imagem, projeto que teve como fruto as vinhetas para o festival. Foi um ano de muitas atividades, porém ao chegar 2016 a escola não teve seus patrocínios renovados e permaneceu o ano fechada.

Durante praticamente todo processo de escrita desta tese me deparei com esta situação: sede fechada, com a distribuição das coleções de livros e DVDs da ELC, que foi anunciada pela produção da escola nas redes sociais e com a falta de 
perspectiva de reabertura. Prestes a fechar este texto recebi a notícia de que a escola vai organizar mais uma edição do festival de Cinema da cidade de Nova Iguaçu (IGUACINE).

No que se refere à estrutura, a ELC manteve um formato institucional semelhante desde seus primeiros anos. Funcionando com uma coordenação, um produtor e mediadores (o número de mediadores costuma variar a cada ciclo). A forma como isso se organiza muda a cada processo, com a entrada e saída dos diversos colaboradores. Durante o ano de 2014, período em que estive na escola fazendo a pesquisa de campo, a escola funcionou sob a produção de Luana Pinheiro, com a assistência de Beatriz Stassen e tinha como mediadores: Diego Bion (que atuou especialmente na coordenação pedagógica), Diana Vieira (atuando mais diretamente nas aulas de linguagem cinematográfica e também dando reforço durante as aulas de corpo e dança), Luísa Coser e Priscila Maia, atuando como colaboradoras nas aulas de dança e corpo.

Luana Pinheiro e Diego Bion foram alunos da ELC no seu início, na primeira turma que funcionou após a abertura da sede da escola, em 2007 e Beatriz Stassen foi aluna na turma de 2011.

No formato de trabalho com parcerias é recorrente que na escola apareçam novos projetos e formatos de turmas a cada ciclo. Durante o ano de 2014, especificamente, a ELC trabalhou com dois formatos: a turma tradicional de videoarte, formada por alunos do contraturno escolar, na faixa etária de 12 a 18 anos e, durante o mês de outubro, teve início uma "oficina relâmpago de produção audiovisual", foram oficinas rápidas, com 8 aulas distribuídas ao longo de 8 sábados e que teve como proposta o trabalho com a linguagem cinematográfica, noções de câmera e montagem para pessoas com idade a partir de 17 anos.

\subsubsection{Um ano em Austin}

O ano letivo na ELC foi dividido em dois semestres, durante o primeiro os encontros foram focados no ensino da linguagem cinematográfica por meio de exercícios com a câmera e atividades que incentivam a formação de um reportório, com referências de filmes e vídeos previamente escolhidos pelos mediadores e apresentados aos alunos. Ainda nessa etapa os mediadores conversaram sobre a possibilidade de criação de algum vídeo ou videoinstalação 
com a intenção de explorar a relação do corpo e da dança com o vídeo, a ideia inicial foi proporcionar experiências com a videodança ao longo do semestre, o que incluiu uma visita ao Museu de Arte do Rio, para assistir à mostra de vídeo do Projeto Dança em Foco, que fez parte do Festival Internacional de Vídeo e Dança.

A gente é mais o caminho da videoarte, que não é o cinema chamado clássico narrativo, com histórias, começo, meio e fim. $\mathrm{Na}$ verdade usamos essas imagens como maneira de expressão, da experimentação mesmo. Experimentar. Experimentar coisas. Vai ser mais ou menos isso que a gente vai fazer (Anotações de pesquisa sobre a ala do mediador - aula 1)

O primeiro mês de encontros foi acompanhado por dois mediadores que também são moradores da Baixada Fluminense e já trabalhavam há um tempo com produção cultural. Um deles está na ELC desde seu primeiro ano e atuou em todas as turmas de videoarte formadas até o fim daquele ano. A partir do segundo mês de aula as turmas passaram a ser acompanhadas por mais duas colaboradoras que são bailarinas por formação, responsáveis por trabalhar a relação do corpo no cinema e no vídeo e a relação da dança com a história da linguagem cinematográfica, estas colaboradoras são moradoras da cidade do Rio de Janeiro e durante as aulas se deslocavam semanalmente para Austin.

$\mathrm{Na}$ tentativa de auxiliar os alunos na formação de um repertório, os mediadores responsáveis pela aulas de linguagem cinematográfica trabalharam com os filmes explorando elementos da imagem, como movimento de câmera, planos etc. A escolha dos títulos foi feita pelos mediadores, que inicialmente adotaram a estratégia de variar os filmes e vídeos a cada encontro e posteriormente passaram a trabalhar com uma obra principal, trazendo para sala o DVD com os episódios de 5x Favela, agora por nós mesmo (2010), filme que envolveu jovens de comunidades cariocas em oficinas e treinamentos de audiovisual, ministradas por grandes nomes do cinema brasileiro, como Nelson Pereira dos Santos, Ruy Guerra, Walter Lima Jr., Daniel Filho, Walter Salles, Fernando Meirelles, João Moreira Salles. Durante as aulas de corpo e vídeo ministradas pelas colaboradoras, os filmes escolhidos exploravam, em sua maioria, a relação do cinema com a dança.

As exibições dos filmes eram acompanhadas por exercícios com a câmera, onde as crianças testavam os movimentos, ângulos e demais elementos da linguagem. Esse tipo de proposta aproxima os alunos não só da estrutura que 
compõe a construção imagética, mas busca estimular o exercício de imaginar o processo de criação dessas obras, abordando o cinema de forma aberta e como defende Bergala (2008), "sem trair sua natureza" (p. 127). Desse modo, o cinema não começa a ser abordado pelas definições de movimento de câmera e de escala dos planos. Podemos também nos aproximar do que Rancière (2004, p. 97) defende ao pensar no ensino da pintura para crianças, atentando que seria perigoso dar-lhes explicações sobre as medidas que devem tomar antes de começarem sua obra. Para o autor, existe aí o risco de que com isso a criança sinta-se incapaz. Trata-se de permitir que o exercício de imaginar seja feito, ao contemplar uma pintura e tentar interpretá-la, ou ao imaginar quais os processos envolvidos no processo de criação dos filmes. Imaginar não é saber o que realmente foi feito ou pensado, mas é o exercício livre, uma forma de conhecer, pela experiência, pelo ato de experimentar.

Também Montaigne (2010), conforme se vê no ensaio escolhido para fechar sua coletânea, ocupa-se do exercício de pensar o desejo humano pelo conhecimento, especialmente o conhecimento adquirido pela via da experiência. Nesse sentido, ele aproxima noções do cotidiano à experiência, ao exercício de nos escutarmos. E assim defende:

\footnotetext{
A vida de César não é mais exemplo para nós do que a nossa. Tanto de um imperador como de um homem do povo, é sempre uma vida, à qual todos os acontecimentos humanos dizem respeito. Nós nos dizemos tudo de que mais precisamos: basta escutarmos (MONTAIGNE, 2010, p. 522).
}

Podemos continuar fazendo esse movimento de aproximação entre este exercício de escuta (que também pode ser lido como um exercício de observação do nosso entorno e do que fazemos) e as lições de Joseph Jacotot (RANCIÈRE, 2004), especialmente quando as ações do mestre provocam no aluno uma espécie de "impulso de busca" pelo conhecimento. Na ELC após a etapa de exercícios com base nos filmes, os mediadores incentivaram os alunos a fazerem filmagens com base em pequenas histórias criadas por eles e gravadas nas ruas de Austin. $\mathrm{O}$ território é um elemento constante nas aulas, sendo trazido a cada instante pelos mediadores, seja por meio de gravações externas, exercícios de observação desenvolvidos pelas ruas do bairro ou uma conversa sobre os personagens que a rua traz. Nas filmagens os planos e movimentos de câmera eram explorados a 
partir do esforço do aluno para pensar sua história imageticamente e no exercício de materializá-la.

Diante de oficinas como estas os problemas a serem resolvidos exigem tomadas de decisão por parte dos alunos e possuem uma dimensão diferente das tomadas de decisão do cinema comercial. Filmar na rua, por exemplo, deixa de ser somente um exercício de posicionar a câmera em um ponto fixo, mas passa a exigir deles que escolhas sejam feitas e executadas: a posição da câmera, os ajustes de luz e som, a decisão de quem vai filmar, quem vai escolher o local, quem vai conversar com as pessoas na rua etc. Na maioria das vezes tudo é novo para a maior parte dos alunos.

Com o início do segundo semestre, os mediadores lançaram um desafio aos alunos: fazer um vídeo pautado na videodança. As ideias iniciais começaram a ser lapidadas junto aos alunos, o gesto cinematográfico permeado por múltiplas subjetividades seria a essência a dar forma ao projeto, importava que as múltiplas visões e possibilidades encontrassem espaço, um palco, para se desenvolverem. À medida que os encontros iam acontecendo, uma espécie de movimento trazia novas imagens e os alunos se envolviam mais com o processo e inevitavelmente com o território, que servia de cenário. As aulas retomavam as referências trabalhadas durante o primeiro semestre e voltavam agora com comentários dos alunos, que inicialmente ouviam timidamente o que os mediadores diziam.

A primeira aula do segundo semestre trabalhou com uma pergunta: $\mathrm{O}$ que é um tema? A partir disso os mediadores incentivaram os alunos a identificarem um tema central e assuntos num filme, usando como exemplo o vídeo Tango, do polonês Zbigniew Rybczyński (1980) e o filme O Baile, do italiano Ettore Scola (1983). A intenção era, então, trabalhar o fluxo de tempo como temática. Poucas aulas à frente, os alunos exercitaram pensar um tema para sua própria produção.

Já no dia 30 de julho os mediadores apresentaram o projeto de forma mais sistemática e durante a aula de vídeo e corpo foi relatado que a ideia era que os alunos passassem a colecionar gestos, materialidades, sensações e a cada encontro isso seria trabalhado coletivamente através de listas feitas por cada um, para criação de um catálogo que definisse aquele território. Para tornar isso claro os mediadores usaram como exemplo a obra de Arthur Bispo do Rosário, enfatizando que a produção desse artista foi feita essencialmente a partir do material que ele tinha no seu local de convivência, um hospital psiquiátrico. Desta 
forma, surge uma questão: como seria pensar o centro de Austin a partir das obras de Bispo? Os mediadores tinham como objetivo naquela etapa fazer ver aquele território e, com isso, trouxeram para a sala a metodologia baseada nos conceitos que norteiam o trabalho da ELC: "palavra, corpo e território".

A ideia de "colecionar coisas" foi desenvolvida em etapas. Primeiro foi feita uma coleta de imagens, com base em temáticas diferentes a cada semana: coletar gestos, depois coletar materialidades, sensações, seres vivos e grupos sociais. Os alunos saíram em grupos, cada um deles acompanhado por um mediador e após fazem uma pequena lista de imagens possíveis, elas eram filmadas pelos membros dos grupos, que se revezavam. Em seguida essas imagens foram selecionadas para então virarem um catálogo de imagens de Austin e assim, darem origem a gestos e estes, às coreografias que foram a base do vídeo. Após a etapa de elaboração da coreografia, já nas últimas aulas, os mediadores, juntamente com os alunos, selecionaram o material a ser usado no vídeo e após fim das aulas, na primeira semana de novembro, o processo de montagem e finalização do filme foi iniciado pelos mediadores sem a interferência dos alunos e sem a formalidade de horário e local fixos, inviabilizando a continuidade de minhas observações sistemáticas do processo de produção. No fim daquele mesmo mês o lançamento do vídeo intitulado por Montão de Coisa foi feito no terraço da ELC, em Austin, com a presença dos alunos e seus familiares, assim como dos mediadores, colaboradores e produtores envolvidos no processo. 


\section{De onde veio este Montão de Coisas?}

\subsection{Para ler o processo criativo da videodança}

É preciso que haja uma necessidade, tanto em filosofia quanto nas outras áreas, do contrário não há nada (DELEUZE, 1999, p. 3).

A citação de Deleuze que abre este capítulo demonstra o viés da leitura que faço sobre o processo de criação nesta pesquisa, momento que abriga o gesto de criação, permeado pelo trabalho, pela inspiração, pelo acaso, pela intuição, pela necessidade, pelo nascimento das ideias. Segundo Deleuze, é preciso que haja uma necessidade, pois é ela que nos leva ao ato de criação. Ela pode surgir de um desejo, de uma condição, de uma situação ou como fruto do encontro entre o sujeito e o mundo. Em um diálogo com estas ideias, aproximo o pensamento de Ostrower (2004), que também considera que a natureza criativa do homem passa pela intencionalidade da sua ação e acrescenta:

$\mathrm{O}$ ato intencional pressupõe existir uma mobilização interior, não necessariamente consciente, que é orientada para determinada finalidade antes mesmo de existir a situação concreta para a qual a ação seja solicitada (p. 10).

Apresento aqui uma abordagem do processo criativo em sua essência, ou seja, explorando seu alicerce e os elementos fundamentais da gênese do gesto de criação, discutindo a natureza criadora do homem, sua forma de estabelecer relacionamentos para formar novas coisas, para fazer um filme, uma poesia, um curta, uma videodança ou um vídeo para o Youtube, para assim falarmos das tantas possibilidades que a relação entre nós, a sociedade, a tecnologia e os processos criativos propicia.

Durante a construção desta pesquisa, ainda no processo de escrita do projeto, uma das primeiras coisas a serem definidas foi a escolha pelo processo de criação cinematográfico como momento a ser investigado. Justifico isso no capítulo 2 desta tese, enfatizando a opção por trabalhar com uma empiria que nasce durante o processo de pesquisa. Neste capítulo a investigação é conduzida no sentido de perscrutar e revelar a estrutura do processo de criação da 
videodança Montão de Coisa, como um projeto desenvolvido pela ELC e acompanhado por mim ao logo do seu período de criação e execução. Trabalho a empiria à luz dos estudos sobre o processo de criação numa perspectiva que o coloca como fruto da integração de três aspectos: o ser consciente, sensível e cultural (OSTROWER, 2004) e o considera um processo existencial.

A artista plástica Fayga Ostrower considera a criatividade inerente ao homem. Para ela, criar é, basicamente, formar. É poder dar uma forma a algo novo estabelecendo relações entre os mais variados eventos que acontecem ao seu redor, pois, "relacionando os eventos, ele [o homem] os configura em sua experiência do viver e lhes dá um significado" (OSTROWER, 2004, p. 9). A percepção do que acontece ao seu redor e a forma como são estabelecidos seus relacionamentos no entanto, não acontecem por acaso, ele o faz colocando-se como ponto de referência e assim, vincula tais eventos, fazendo ordenações. Trata-se de dizer que, embora esse processo tenha um caráter intuitivo, não é, em última instância, a intuição que o move. Isso acontece, segundo Ostrower, porque o homem está sempre em busca de significados e nesta busca reside seu impulso para criar.

Impelido, como ser consciente, a compreender a vida, o homem é impelido a formar. Ele precisa orientar-se, ordenando os fenômenos e avaliando o sentido das formas ordenadas; precisa comunicar-se com outro seres humanos, novamente através de formas ordenadas. Trata-se, pois, de possibilidades, potencialidades do homem que se convertem em necessidades existenciais. $\mathrm{O}$ homem cria, não apenas porque quer, ou porque gosta, e sim porque precisa; ele só pode crescer, enquanto ser humano, coerentemente, ordenando, dando forma, criando (OSTROWER, 2004, p. 9-10).

Durante seus ciclos de produção a Escola Livre de Cinema de Nova Iguaçu assume um trabalho que tem como norte proporcionar uma experiência no/com cinema. Essa busca passa pelo desenvolvimento de várias atividades que envolvem temáticas específicas, definidas a cada novo projeto, assim como o contato com a linguagem cinematográfica, ações e atividades a serem desenvolvidas no território (no Bairro). É durante esta experiência que o momento de criação acontece, enquanto aprendem algo novo sobre o cinema, eles são incentivados a criar. 
Ao longo da experiência, os processos criativos acontecem na esfera da intuição e tornam-se conscientes na medida em que são expressos, em que são desenvolvidos e ganham forma. Nesse processo, movido pela necessidade de criar, o homem age e "não somente percebe as transformações como sobretudo nelas se percebe" (OSTROWER, 2004, p. 10), a percepção de si mesmo é parte inerente da criação e permite ao homem a capacidade de resolver problemas, de achar soluções. Sobre o ser sensível Ostrower aponta a sensibilidade como "a porta de entrada das sensações (...) [ela] representa uma abertura constante ao mundo e nos liga de modo imediato ao acontecer em torno de nós" (2004, p. 12). Sobre a sensibilidade, a autora defende que parte dela está ligada ao inconsciente. Nisto encontramos as reações involuntárias do nossos organismo, enquanto outra parte está relacionada ao nosso consciente, à nossa percepção. Concluindo assim que "a percepção é a elaboração mental das sensações" (p. 12), envolvendo o sentir e o compreender. No que diz respeito ao consciente, este não é visto como um fator negativo no processo de criação, e sim é tratado por ela como uma percepção consciente, parte constituinte do processo, fator fundamental na elaboração. No que se refere ao ser cultural como um dos aspectos presentes e influentes no processo de criação, Ostrower (2004) parte da noção que direciona seu pensamento sobre cultura:

\footnotetext{
Procuramos definir aqui o que entendemos por cultura: são as formas materiais e espirituais com que os indivíduos de um grupo convivem, nas quais atuam e se comunicam e cuja experiência coletiva pode ser transmitida através de vias simbólicas para a geração seguinte (2004, p. 13).
}

Nesse sentido, ajudam-me também as proposições de Clifford Geertz (2015) a respeito de como a cultura nos constitui, nos move e promove seu próprio movimento de produção e reprodução nas sociedades.

A escolha por uma aproximação aos pressupostos apresentados por Ostrower demonstram o viés de leitura do processo de criação adotada aqui, importante para entender como a experiência da ELC foi abordada. Diante de uma experiência que tem como objetivo proporcionar um encontro dos alunos com o cinema através de ações de criação, considero esta uma experiência estética e aproximação com a arte cinematográfica, seus elementos, linguagens e aspectos estéticos. 
A seguir, tratarei das oficinas realizadas na ELC e do trabalho com a coleção de imagens que gerou a videodança Montão de Coisa. As idiossincrasias ali percebidas e os modos pelos quais alunos e mediadores propuseram e realizaram tais exercícios também os insere no contexto de produção cultural percebido e problematizado.

\subsection{A dimensão da experiência no processo de criação}

A experiência é algo que (nos) acontece e que às vezes treme, ou vibra, algo que nos faz pensar, algo que nos faz sofrer ou gozar, algo que luta pela expressão, e que às vezes, algumas vezes, quando cai em mãos de alguém capaz de dar forma a esse tremor, então, somente então, se converte em canto (LARROSA, p. 10, 2014).

Na citação que trago para a abertura desta seção Larrosa (2014) utiliza uma metáfora relacionada à música para se referir à experiência. Tratando a experiência como um canto, ele cita os efeitos seus efeitos (que treme, vibra...) em outros cantos, ou seja, em outras experiências. Utilizando a mesma metáfora, podemos pensar que essa experiência ressoa em outras, em outros cantos e, atravessando espaço e tempo, faz surgir novos cantos, em um encontro marcado pela alteridade. Este encontro se faz essencial para pensar a experiência com o cinema como proposta da ELC, é ele [o encontro] que nos faz compartilhar outras experiências, que sem o cinema permaneceriam ignoradas.

Neste sentido, a noção de experiência da qual me aproximo para pensar o trabalho da ELC é aquela desenvolvida por Larrosa (2011), que a considera como um acontecimento que atravessa e marca o sujeito. É o passar de algo que não conheço ou conhecia. Esta dimensão da experiência me leva a pensar o encontro com o cinema e também com o mundo que ele pode nos fazer ver. Para Bergala (2008, p. 38) é este movimento que nos faz ver o novo, o diferente, o que não conhecíamos. O contrário disto, o medo da alteridade, nos leva a "anexar um território novo ao antigo (...) não enxergando no novo senão aquilo que já se sabia ver no antigo". 
A afirmação de Larrosa (da experiência como algo que nos passa) nos apresenta algumas dimensões: seu caráter de alteridade (outra coisa diferente de mim) e a exterioridade (do encontro, o que me encontra ou o que é exterior a mim). Podemos pensar também que no sujeito a experiência tem o seu lugar, este é o princípio da subjetividade ou reflexividade ou ainda transformação (refere-se ao sujeito da experiência).

Poderíamos dizer, portanto, que a experiência é um movimento de ida e volta. Um movimento de ida porque a experiência supõe um movimento de exteriorização, de saída de mim mesmo, de saída para fora, um movimento que vai ao encontro com isso que passa, ao encontro do acontecimento. E um movimento de volta porque a experiência supõe que o acontecimento afeta a mim, que produz efeitos em mim, no que eu sou, no que eu penso, no que eu sinto, no que eu sei, no que eu quero, etc" (LARROSA, 2011, p. 6-7).

O que passa relaciona-se à travessia, à passagem, ao sujeito da experiência como território de passagem. “(...) Como uma superfície de sensibilidade em que algo passa e que 'isso que me passa', ao passar por mim ou em mim, deixa um vestígio, uma marca, um rastro, uma ferida" (LARROSA, 2011, p. 8).

Proponho que a dimensão da experiência trazida neste texto a partir do trabalho de Larrosa me permite estabelecer um diálogo com a relação do encontro com o cinema trabalhado por Bergala. Para este último, o encontro deve ser marcado pela visão do cinema como arte que nos toca, nos move e confronta. Neste sentido, destaco que o importante nesta investigação é tratar da relação que os alunos e mediadores estabelecem com o cinema na experiência sensível do processo de criação que o projeto permitiu em suas etapas, ao longo dos encontros.

Durante meus primeiros encontros com a ELC, nas entrevistas com Luana Pinheiro e durante a aula que pude assistir na turma de videoarte, ainda a título de estudo exploratório, percebi que uma frase era recorrente na fala deles: "para nós o mais importante é o processo". Ao mesmo tempo que eu ouvia esta frase, me perguntava: o que acontece durante este processo, quais relações são estabelecidas e qual o caráter desta experiência? 


\subsubsection{A experiência estética na arte contemporânea}

As primeiras noções trabalhadas pela ELC para pensar as possíveis dimensões que uma experiência pode tocar são baseadas nos processo vividos e do diálogo do cinema com a arte contemporânea. Levando isto em consideração, passo então a observar as formas de criação de alguns artistas e de como estes desenvolveram/desenvolvem seus processos de criação como uma experiência, com experimentos que procuram romper com as formas tradicionais, como o movimento da arte contemporânea a partir da década de 1960. Como exemplo, podemos pensar nos Ready-mades de Duchamp, que trazem algo de fora para dentro do espaço da arte, colocando o espaço como uma possibilidade de criação e intervenção plástica e conceitual. Processos como estes são emblemáticos para a ELC, que os usa como inspiração para trabalhar suas criações, a exemplo do que aconteceu com as duas videoinstalações que antecederam o processo da videodança Montão de Coisa, nelas a escola desenvolveu um trabalho que procurou criar uma dinâmica entre o objeto, o espaço e o público.

Outro exemplo é o processo de criação desenvolvido por Hélio Oiticica para o Parangolé, criado a partir da experiência do artista com o samba e a dança. Brandão (2015) comenta a obra de Oiticica enfatizando o trabalho com o espaço e a forma como o artista via o mundo: para Oiticica, este era "como um grande museu aberto para se vivenciar e criar experiências de arte em seu quotidiano" (BRANDÃO, 2015, p. 85).

\footnotetext{
O mover-se ao ritmo do samba com a diversidade de fantasias que o carnaval proporcionava era uma experiência que despertaria seu interesse e seria transformada em muitos elementos com os Parangolés. Aqui, Oiticica parece querer levar o espectador para dentro de uma obra de arte, para dentro de formas, cores e texturas. Ao vesti-las, passa a vivenciar nova experiência para além de um encontro visual, mas de todo o corpo (BRANDÃO, 2015, p. 85).
}

Ainda observando o fazer artístico característico das décadas de 1960 e 1970, os espaços eram vistos como são aqueles nos quais os artistas realizam suas investigações, ou coletam elementos para integrar seus projetos artísticos, transformando os espaços urbanos em um grande campo de intervenções. Inspirando-se nisto, a Escola de Cinema de Nova Iguaçu, propõe aos seus alunos 
uma aproximação com o território de Austin. É certo que o trabalho pautado nesta relação não nasce quando a ELC passa a trabalhar com a videoarte e a fazer uma aproximação com as obras da arte contemporânea, mas podemos dizer que ela se intensifica na maneira como o território passa a fazer parte não só da experiência de criação, mas também como esta experiência aparece impressa e enfatizada nos vídeos, videoinstalações e videodanças produzidos depois de 2013.

Entendo que o movimento de tomar as experiências de criação da arte contemporânea, especialmente aquelas desenvolvidas por artistas consagrados, para encaminhar uma análise do fazer cinematográfico que não tem o filme como fim pode parecer arriscado. Montão de coisa nasce de um projeto que o não tinha como objetivo central, mas sim, uma experiência de encontro com o cinema, como trabalhado na abertura desta seção. A escolha deste caminho no entanto, não estava dada, ela foi se fazendo ao longo da pesquisa, especialmente no jogo e na tentativa de achar ferramentas e chaves de leitura que dessem conta destas imagens e deste processo. Na arte contemporânea o processo faz parte da obra e é justamente este movimento que me interessa (e inspira) na observação da experiência de criação da videodança aqui discutida.

\subsubsection{A experiência estética no documentário contemporâneo: trabalhando com o noção de dispositivo}

Tomando a dimensão da experiência como um encontro com o cinema pautado por um caráter de alteridade, de encontro com o outro, tensiono pensar a dimensão estética desta experiência. Especialmente no que diz respeito a sua forma de expressão, apresento aqui uma leitura possível do encontro da escola com a dimensão ensaística do documentário brasileiro contemporâneo, especialmente na reflexão que este carrega sobre o cotidiano, o comum e sobre sua natureza provisória e exploratória. 
Todo processo de construção da videodança Montão de Coisa é construído com base em dispositivos, trata-se de exercícios ${ }^{20}$ propostos pela ELC durante o processo de criação e produção.

Para a escola importa criar situações em que alunos e mediadores encontrem um terreno propício para criação das imagem. Fazendo ligação deste processo com o elementos do cotidiano, pensando a relação deles com Austin ou o encontro com o mundo, explorando, por exemplo, o caminho que eles percorrem até a escola, o percurso que leva à padaria ou o caminho que seus pais percorrem para ir ao trabalho. Tudo isso pode virar uma cena ou uma coreografia. Estas situações podem ser lidas como "esforços para", "tentativas" e "testes", onde o risco do "não se realizar" é iminente e perfeitamente aceitável diante da experiência que o fazer cinematográfico ali desenvolvido proporciona.

Em meio a esse movimento aparece o trabalho com os fundamentos da linguagem cinematográfica, explorando planos, enquadramento e montagem, experimentos como o "efeito Kuleshov", ou explorando conceitos de raccord e Jump Cut como estratégias narrativas de montagem, fazendo com que a linguagem cinematográfica apareça para capturar atividades rotineiras dos alunos. Um exemplo prático disto é o exercício chamado Minuto Lumière, que consiste em escolher um lugar para gravar um plano de um minuto com a câmera parada. Significa captar um minuto do mundo, do movimento da rua, dos lugares característicos de Austin.

Ao longo do processo de criação da videodança Montão de Coisa, um dos desafios feitos aos alunos foi coletar imagens para formar álbuns de materialidades (o chão, as texturas das árvores, as cores da rua, os objetos característicos da estação de trem), um catálogo de imagens dos seres vivos que habitam as ruas de Austin, dos sentimentos e sensações que permeiam as ruas: os gestos da rua, do cotidiano, os gestos da moça que distribui panfletos pela rua, do motoqueiro que espera o cliente no ponto do moto táxi, do vendedor de verduras, ou de roupas, ou de relógios, ou de panelas tentando atrair seus clientes pela passarela do centro de Austin.

Esta dimensão da criação assumida pela ELC descreve um vínculo entre a subjetividade dos alunos e os acontecimentos circundantes do território no

\footnotetext{
${ }^{20}$ Ao longo deste texto utilizei as palavras "dispositivos", "exercícios" e "atividades" como sinônimos, para me referir às atividades propostas ao longo do processo.
} 
momento de criação e da produção. Desta forma, este movimento testemunha não só as constantes mudanças e os ajustes das ideias daqueles que se submeteram à experiência do fazer cinematográfico, mas também a transformação do eu formador (no sentido de criador) como parte desse processo, privilegiando a expressão visual e a subjetividade.

Este processo de escrita através dos exercícios remete à noção de dispositivos fílmicos, trabalhados por Consuelo Lins e Cláudia Mesquita (2011) como uma "noção [que] remete à criação, pelo realizador, de um artifício ou protocolo produtor de situações a serem filmadas" (p. 56), estas situações, por sua vez, apresentam pequenos problemas a serem resolvidos e são seguidas por ações concretas de busca, o que institui condições para que aquelas imagens sejam gravadas e assim, para que o filme aconteça.

Caminhando na direção oposta de um roteiro previamente instituído, que teme o que nele provoca fissuras, os dispositivos fílmicos têm como característica a possibilidade real da "não realização", da rasura, e nisso se aproximam do ensaio fílmico, como processo de escrita. "A simples adoção de um dispositivo não garante, em suma, o sucesso de um filme; tudo depende de sua adequação ao assunto eleito, mas sobretudo do trabalho concreto de filmagem, que a maquinação anterior não dispensa" (LINS; MESQUITA, 2011, p. 57).

Esta noção de dispositivo discutida por Lins e Mesquita (2011), sobretudo como uma estratégia criativa e política na construção da imagens do documentário contemporâneo tem origem na década de 1960. Deste período destacam-se trabalhos como os de Robert Drew e Jean Rouch, Migliorin (2008) lembra em sua tese de doutorado que, "no campo do documentário, o filme-dispositivo pode ser visto como um desdobramento de um tipo de produção que podemos identificar nos anos 60, conhecida como Cinema-Verdade" (p. 42). Desta forma, para os cineastas que se propuseram a explorar este viés, o filme se faz a partir de uma outra relação com o contexto.

O que será narrado pelo filme não é mais um mundo in natura, mas um universo aberto ao movimento das ruas e à relação do mundo com o realizador e com o cinema, trazendo as questões éticas relativas à lógica do encontro entre indivíduos em lugares distintos, com poderes distintos (MIGLIORIN, 2008, p. 43). 
Explorar esta origem do documentário que se faz a partir dos agenciamentos com os dispositivos fílmicos nos ajuda a ler a produção e a maneira como o trabalho da ELC se estrutura, através do uso de dispositivos em meio a uma experiência de criação. Estas estratégias criativas produzem acontecimentos que recusam o controle, o roteiro ou a busca precisa por determinada imagem.

Proponho agora pensarmos a experiência da ELC com Montão de Coisa a partir de uma metáfora: como se observássemos um vídeo através de um caleidoscópio. Provavelmente a imagem mais marcante seria a combinação de fragmentos, que mudaria a cada girar da lente. Estes estariam ordenados e vinculados uns aos outros, mas também possuem um significado independente, se observados em suas pequenas partes. São estas imagens que contemplamos ao observarmos o resultado de cada dispositivo, de cada exercício. São fragmentos que formam a videodança. Partes que também podem ser independentes.

A experiência de criação dessa videodança pode ser também equiparada à escrita de um ensaio na sua maneira de privilegiar a expressão visual e a subjetividade, que permeiam todo percurso da câmera ao longo do vídeo, dramatizando o encontro do eu com o mundo. Neste sentido, Pereira (2014) aproxima o filme-ensaio de um certo cinema da experiência, como aquele que é fruto da experiência e dos gestos de criação do seu autor. Nesse processo marcas subjetivas são impressas nas imagens produzidas e há uma preocupação para além da representação da realidade, de um determinado espaço ou cultura.

Não se trata de classificar Montão de Coisa como um filme-ensaio, pois se fossemos pensar em uma classificação, certamente ela não seria possível. Antes, trata-se de pensar as marcas do filme-ensaio neste vídeo. A presença de Austin como personagem, dos alunos como aqueles que executam a coreografia com os gestos construídos a partir da catalogação.

O trabalho de sistematização do processo de criação apresentado ao longo desta tese evidencia a importância que os dispositivos no processo de criação da videodança Montão de Coisa e na estruturação da metodologia da escola. Estes pequenos "disparadores" colocam alunos e mediadores diante de situações a serem filmadas e problemas a serem resolvidos, que resultam em imagens, fragmentos que posteriormente vão compor a videodança. $\mathrm{O}$ encontro com o cinema na ELC passa sempre por uma experiência de criação, o que não impede que em meio a isso a formação do repertório faça parte do trabalho, com a 
exibição de filmes e debates. Com a criação de imagens e sons fazendo parte do cotidiano ao longo do processo, o aprendizado passa por uma relação criativa e crítica por parte dos alunos, desta forma se aprende fazendo. Sobre este encontro permeado pela alteridade, Migliorin (2015) pensa:

Entender a rua, o bairro, o vizinho e a cidade com o cinema é entrar numa relação com o outro e, simultaneamente, em uma atividade crítica e criativa - do plano, do quadro, da luz, do ritmo. Em outras palavras, aproximar os estudantes do que o mundo tem a nos dar e, simultaneamente, permitir que eles criem e inventem com esse mundo (MIGLIORIN, 2015, p. 10).

Os dispositivos podem ser pensados como "pequenos problemas para se resolver juntos", como os apresenta Cezar Migliorin no catálogo comemorativo de 5 anos da ELC, lançado em 2011. Estes "pequenos problemas" estruturam a metodologia da escola, tornando-a flexível e adaptável a diversos projetos. Não se trata de "regras inalteráveis para um encontro com o cinema", mas sim de uma base para o desenvolvimento de atividades e criação de imagens, a forma como isso é executado depende do projeto e do enfoque que se pretende suscitar.

Chamávamos esses 'pequenos problemas' de dispositivos. Eles nos obrigariam a circular pela cidade, a pesquisar imagens, textos e obras e a fazer encontros com pessoas e instituições que normalmente não faríamos $\mathrm{e}$, tudo isso, mediado pela necessidade de fazer imagens e sons que se desdobrassem de experiências com o mundo (MIGLIORIN, 2011, p. 6).

Dispositivos são exercícios, jogos, desafios com o cinema, um conjunto de regras para que o estudante possa lidar com os aspectos básicos do cinema e, ao mesmo tempo, se colocar, inventar com ele, descobrir sua escola, seu quarteirão, contar suas histórias. Há dois modelos de dispositivos: aquele com equipamento de filmagem e gravação de som e aquele sem equipamento (MIGLIORIN et al., 2016, p. 14 - grifos meus).

Estes desafios pautaram as primeiras experiências dos alunos com o cinema na ELC, guiando encontros com o bairro de Austin por uma outra perspectiva, transformando o comum em imagens, numa experiência não roteirizada, aberta ao imprevisto, ao acaso e ao instante. Uma situação, um problema, ações necessárias e soluções fazem parte, não necessariamente nesta ordem, deste movimento subjetivo de que demanda gestos de criação.

Neste processo, os mediadores assumem um papel duplo: são aqueles que propõem os desafios aos alunos e ao mesmo tempo, são aqueles que estão ao lado 
destes para a execução da atividade. Neste sentido, eles também - em alguns casos - dependem dos alunos, especialmente quando se trata de informações relacionadas ao território. Nenhum dos mediadores conhece Austin tão bem quanto os alunos, que vivem naquele bairro. E em alguns exercícios conhecer Austin é essencial para o desenvolvimento da atividade.

Ao longo do projeto do ano letivo de 2014 percebi que o uso dos dispositivos foi mais frequente no primeiro semestre, durante a fase que antecedeu o trabalho de catalogação das imagens de Austin para a coleção. Naquele ano o uso dos dispositivos foi afetado pela presença de mediadores que estavam na escola pela primeira vez. As mediadoras responsáveis pelas aulas de "corpo, cinema e dança" se aproximaram dos dispositivos aos poucos, em ações tímidas, mas que de certa forma complementavam o trabalho já desenvolvido.

O cronograma de execução do projeto foi planejado para ser efetuado pelas 4 turmas de videoarte, o que aconteceu somente até certo ponto. A situação de aparente crise trouxe imagens que, na videodança, eram complementadas através do trabalho de montagem. Fez parte das características do trabalho com dispositivo explorar as possibilidades de cada grupo, privilegiar resultados singulares, pautados pelos interesses e características de cada turma.

\subsection{Componentes fundamentais do gesto de criação}

\footnotetext{
A escola, se quiser abordar o cinema como arte, tem que livrar-se uma vez por todas da velha idéia escolástica de que há um bom modo, e um só, de se dizer alguma coisa e de se filmar uma cena, ou um plano, no cinema (BERGALA, 2008, p. 162).
}

O trecho escolhido para epígrafe desta seção refere-se ao papel da escolarização formal em sua relação com o cinema. Embora este não seja o mote de minha discussão, encontro nele um potencial para pensarmos também os movimentos da ELC a partir das experiências ali vividas durante a pesquisa. A proposta de Bergala foi desenvolvida com base no sistema de educação escolar francesa e a sistematização apresentada por ele no livro A hipótese-cinema pequeno tratado de transmissão do cinema dentro e fora da escola (2008) nasceu de um convite que o autor recebeu para integrar um grupo de conselheiros que iria 
desenvolver um projeto de educação artística e de ação cultural na Educação Nacional Francesa. Nesta pesquisa, os pressupostos do autor auxiliam metodologicamente a análise, pois me permitem elencar os elementos fundamentais do gesto de criação.

Neste capítulo apresento uma análise do processo de criação da videodança Montão de Coisa, direcionando o olhar para os componentes fundamentais do gesto de criação com o objetivo de construir um caminho, uma passagem para abordar sua metodologia de trabalho e a experiência do fazer cinematográfico e audiovisual na escola, que serão discutidos no quarto capítulo desta tese. Para desenvolver meu trabalho nessa perspectiva, tenciono estabelecer um diálogo com Alain Bergala, especialmente com sua metodologia de análise de criação, onde o autor propõe um retorno ao momento imediatamente anterior à inscrição definitiva das coisas, instante onde as múltiplas escolhas simultâneas se colocam para aqueles que fazem cinema.

É para cortar aqui ou ali? Onde começa a próxima cena? (anotações de pesquisa sobre fala do mediador - aula 27).

$\mathrm{Na}$ ELC, durante o gesto de criação, embora os objetivos estejam, de antemão, definidos, as escolhas não estão postas nem para alunos nem para os mediadores. Ambos atuam de forma complementar, especialmente quando o foco é o momento de decisão. Esse trabalho de mão-dupla acontece por meio da atuação e do diálogo num processo coletivo. Para entender o papel desses sujeitos no processo, defendo que devemos olhar para as práticas da educação não formal ali presentes, que segundo Gohn (2013), emergem do processo de aprendizagem que parte da cultura dos indivíduos e dos grupos, "a partir da problematização da vida cotidiana" (versão kindle, posição 552), do modo de agir e de pensar o mundo que os circunda.

O mediador atua desafiando o grupo de alunos para a descoberta dos contextos onde estão sendo construídas as imagens, dinamizando e tornando o processo participativo, através do diálogo tematizado que atua como fio condutor na experiência com/no cinema. Os exercícios propostos, que se apresentam ancorados por temas do universo da linguagem cinematográfica, da videodança, da dança ou do corpo, são norteados também pela busca de uma atuação no território que torna aquele local ora cenário, ora a temática da produção. 


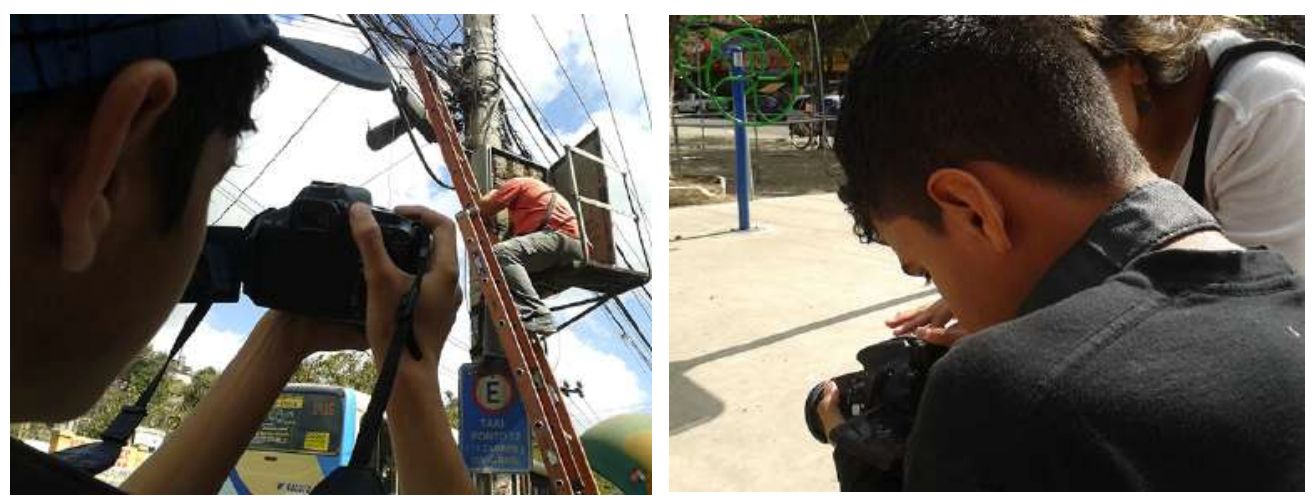

Imagem 6 - Alunos e mediadores em gravação pelas ruas de Austin (08/08/2014) • créditos: Theresa Medeiros

Discutindo os modos de abordagem do processo criativo, Bergala defende que voltar a estes instantes significa considerar que o processo de criação não é fruto de uma sistematização rígida, única e de "um bom modo". Significa aceitar que o diretor ou a equipe provavelmente não começaram as filmagens pela primeira sequência do filme, assim como o grupo de alunos da ELC não começou a gravação de forma sistemática, plano a plano, com movimentos de câmera previamente planejados.

A decisão de realizar uma aproximação com o cotidiano dos encontros da turmas foi construída desde o início da pesquisa, que à época da apresentação do projeto ao PPGCOM da PUC-Rio e ainda no período de qualificação apresentava um delineamento diferente de meu objeto, embora já tratasse da mesma questão de investigação. Tendo sido necessários ajustes e redirecionamentos, como é próprio do fazer pesquisa, o enfoque dessa entrada foi modificado, mas não meu interesse por conhecer, por outra via, o processo de criação e a metodologia da ELC.

Acompanhar os encontros de uma das turmas durante um ano possibilitou acompanhar o desenvolvimento de um ciclo de produção da escola, dando-me uma visão do processo de criação e do trabalho nas oficinas que eu não tinha até então. Foi um importante contato exploratório, pois a intenção era mesmo conhecer especificidades, inserir-me naquele contexto de criação e produção como pesquisadora, entender a dinâmica das turmas, dos projetos, dos encontros, da duração, a periodicidade das oficinas e também providenciar outros aspectos da produção da empiria (acesso a documentos, fotos, vídeos, making off e pessoas) 
que compuseram esta coleção apresentada ao longo da tese. Como já foi citado no capítulo 2, devido à minha indisponibilidade de tempo para frequentar as aulas de todas as turmas da ELC em 2014, precisei optar por uma, das quatro turmas de videoarte que a escola tinha.

Ao longo do período, tencionei acompanhar também as reuniões de planejamento organizadas pelos mediadores e a produtora, mas naquele ano a dinâmica das reuniões que rotineiramente aconteciam no primeiro dia útil da semana mudou, elas passaram a acontecer nos intervalos entre as turmas da manhã e da tarde, o que acabou inviabilizando a minha participação, tendo em vista minha indisponibilidade de horários.

Foram 62 encontros assistidos, divididos em aulas que denominei como "aulas de linguagem", por abordarem mais diretamente os aspectos e elementos da linguagem cinematográfica e "aulas de cinema, corpo e dança", que exploram mais estas questões. Optei por não classificar a quantidade de encontros de cada tipo de aula ao perceber que, no último mês de produção, os mediadores estavam todos juntos em sala e trabalhavam os vários aspectos simultaneamente. Avalio esses encontros como uma experiência enriquecedora tanto do ponto de vista pessoal quanto da pesquisa e é sobre ela que tratarei nesta seção, com base nas observações de campo feitas ao longo do ano letivo. Trata-se de registros direcionados para aspectos que chamavam minha atenção em relação ao tema da pesquisa. O que trago, pois, são fragmentos textuais, narrativas produzidas no momento das observações e também após, durante as releituras do material e da elaboração do blog (a biblioteca que produzi com o material durante o ano em que frequentei a ELC), ocorridas entre idas e vindas ao longo do trabalho. Passo, então, a apresentar um pouco sobre a experiência de participar do processo de criação da produção 2014 da ELC, especialmente dos encontros com alunos e mediadores da turma $\mathrm{C}$, da oficina de videoarte. 


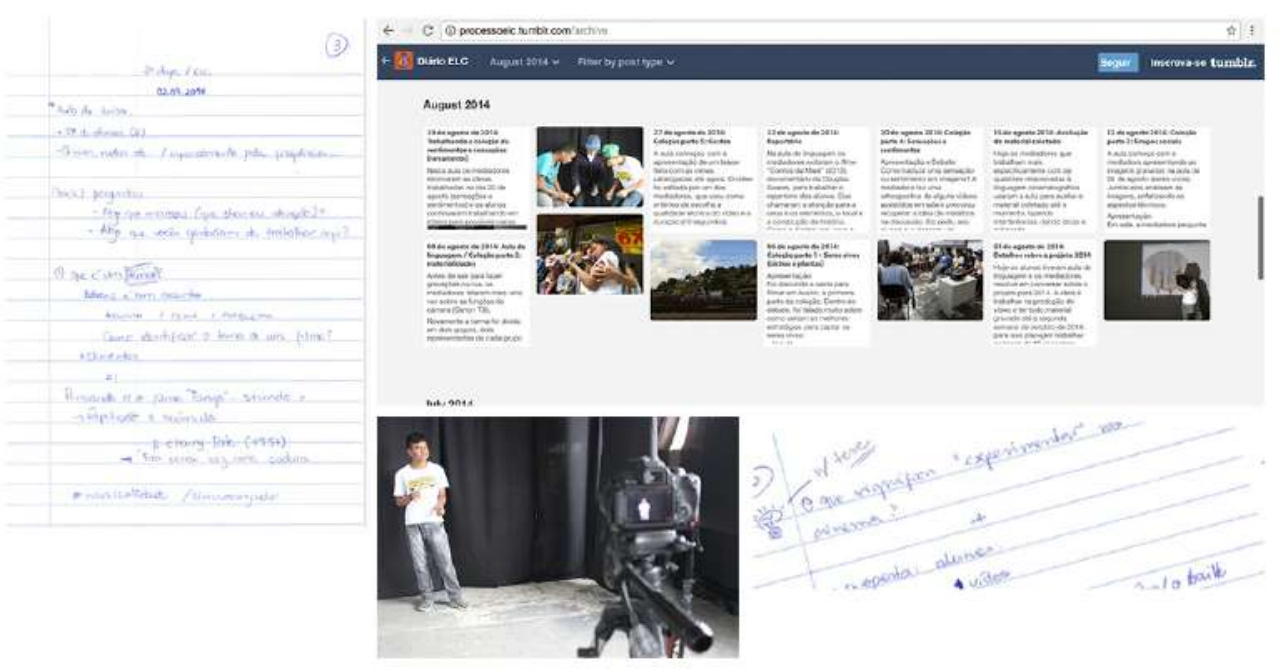

Imagem 7 - Material de pesquisa: anotações, narrativas e imagens - créditos: Theresa Medeiros

Comecei a acompanhar a turma no primeiro dia de aula (12/02/2014), naquele encontro poucos alunos estavam presentes. A ELC optou por continuar acompanhando o calendário da escola regular para determinar o início, o período de férias e o fim do ciclo de oficinas daquelas turmas no ano de 2014, como já era de costume desde as primeiras turmas vinculadas ao programa Bairro escola ${ }^{21}$. No entanto, aquele ano letivo teve um calendário atípico devido à Copa do Mundo FIFA de 2014 que foi sediada no Brasil, fazendo com que todas as escolas precisassem adaptar seus calendários ao grande evento, por questões de mobilidade e dinâmica da cidade. Nesses primeiros dias de fevereiro, com o início das aulas, já podemos considerar que começa o processo de criação da videodança Montão de Coisa, que só começou a tomar forma, com objetivos mais definidos (inclusive, como videodança e não como um filme, uma videoinstalação ou um vídeo), no início do segundo semestre e foi finalizado no mês de novembro do mesmo ano.

Para sistematizar a exposição deste processo de criação e trazer o material empírico para esta seção encaro o ato de criação em suas "operações mentais e operações técnicas" (BERGALA, 2008). A dimensão mental refere-se ao que acontece antes das ações tornarem-se operações concretas, "de se confrontar ao real" (p. 134), fazem parte desta dimensão: a eleição de coisas (dos cenários, das

\footnotetext{
${ }^{21}$ Trabalhei as características destas turmas vinculadas ao programa Bairro escola no capítulo 2.
} 
cores, dos gestos, dos ritmos), a disposição destas (como estão arranjadas com relação umas às outras) e o momento de decisão, nomeado por Bergala como o ataque. As operações técnicas referem-se a elementos como elaboração de roteiro, definição de aspectos visuais do vídeo (cenários, cores, fotografia), locação, gravações, som, edição e finalização.

\subsubsection{A ideia e o formato, sem roteiro}

Pensei no título desta subseção ao reler as anotações que fiz sobre os momentos em que os mediadores apresentaram as primeiras ideias sobre o projeto para Montão de Coisa. A escola - que ao longo dos anos de funcionamento já havia trabalhado com diversos projetos desenvolvidos a partir de um roteiro, num processo muito próximo do fazer documental e ficcional - experimentou, nos seus últimos três projetos, explorar a relação do cinema com a arte contemporânea. Com isso, não trago o "sem roteiro" para enfatizar uma falta, mas para destacar a opção feita pelos criadores do vídeo, que a partir de um dispositivo, ou um desafio, perseguiram a ideia que se transformou na videodança Montão de Coisa.

$\mathrm{O}$ primeiro contato ${ }^{22}$ entre os mediadores e a turma serviu para que eles conversassem sobre o cinema que é feito na ELC, logo depois de uma breve apresentação entre alunos e mediadores (nome, idade, local que mora e o que mais gosta de fazer):

O que a gente faz não é exatamente o filme como a gente está acostumado a ver, o que a gente produz aqui não é feito para ser exibido na sala de cinema, aquela sala toda preta, com cadeiras e uma tela. O que a gente faz aqui é exibido em outros espaços. Vocês já foram a algum museu, centro cultural ou sala de exposição? Tipo, aqui em Austin não tem esse espaço, por isso fica mais difícil. O que a gente faz é o que a chamamos de videoinstalação (anotações de pesquisa sobre fala do mediador - aula 1$)^{23}$.

\footnotetext{
${ }^{22} \mathrm{O}$ relato que trago das aulas não está organizado de forma cronológica, pois percebi que seria inadequado para o tratamento que pretendo dar. O que se verá no texto é uma organização que parte de pontos específicos da empiria, ou seja, das operações analisadas durante o processo de criação.

${ }^{23}$ Todas as citações de anotações feitas durante as aulas serão identificadas pelo número da aula. Contudo, a numeração da aula foi estabelecida pela minha participação e houve poucas, mas algumas ocasiões onde eu não estive presente, de modo que nem sempre a "aula 4" corresponderá à $4^{\mathrm{a}}$ aula dada naquele curso, por exemplo.
} 
Os alunos afirmaram que não conheciam uma videoinstalação e, entre os presentes, nenhum havia ido a um centro cultural ou museu. Então, o mediador optou por apresentar imagens das duas últimas videoinstalações feitas na escola, a \#QueroSer (que é resultado do processo de criação 2012/2013) e a \#Circulando (resultado do processo de criação do segundo semestre de 2013).

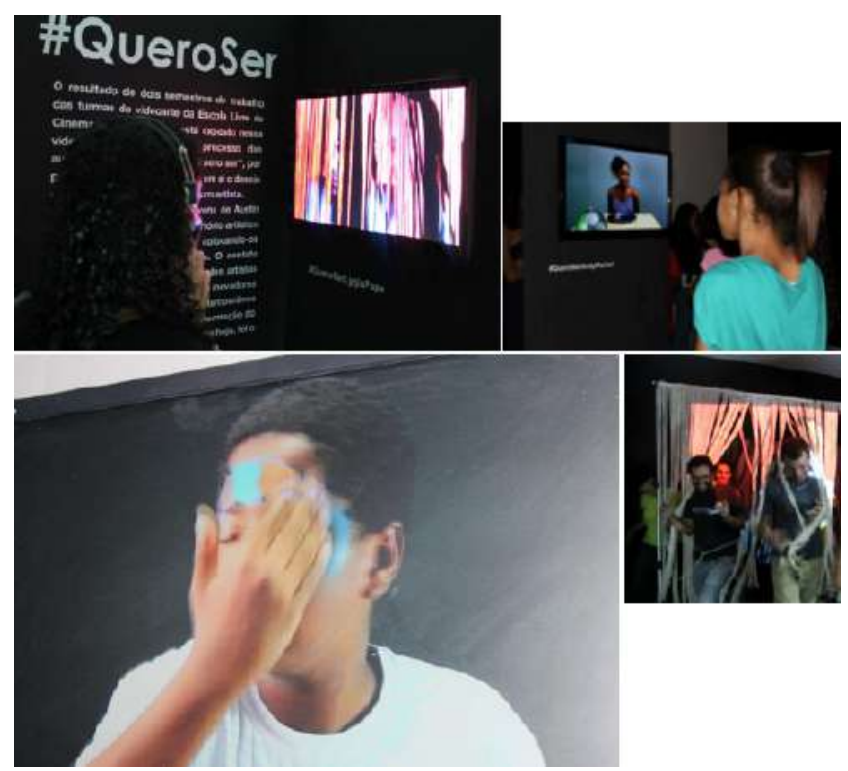

Imagem 8 - Conjunto de frames da abertura da videoinstalação \#QueroSer - créditos: ELC
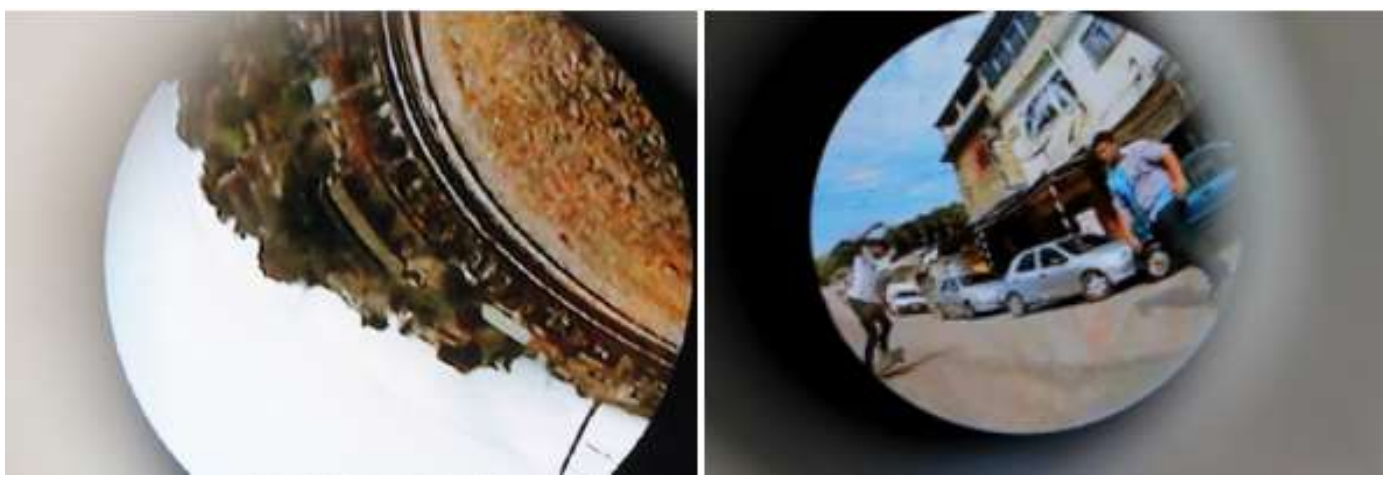

Imagem 9 - Frame a) e b) do vídeo da \#circulando - créditos: ELC

Ao longo da fala do mediador sobre as videoinstalações, ele apresentava os dispositivos técnicos (representados nas imagens 11 e 12) que serviram de suporte no trabalho de captura da imagem e exibição, as telas com os vídeos da \#QueroSer, a teia feita de barbante, releitura da obra Ttéia, de Lygia Pape, o suporte para câmera baseado no aparelho inventado por pelo designer francês Oscar Lhermitte e os cilindros que exibiam os vídeos da \#Circulando. Dedicaram 
também grande parte daquele primeiro encontro para descrever a experiência vivida com a videoinstalação \#Circulando, seu objetivo e a relação estabelecida com Austin, com o território. Como nas produções da arte contemporânea, o viés da experiência foi destacado na narrativa sobre as videoinstalações, a ênfase nos detalhes sobre o processo de criação, tornando o processo parte da obra finalizada.

É super interessante, porque como a imagem gira, ela acaba formando outras imagens dentro dela. Neste trabalho tínhamos alguns desafios, talvez o primeiro foi que a gente queria tirar a imagem desse formato quadrado, retangular. A gente queria levar para uma outra forma geométrica. Escolhemos o círculo juntamente pela ideia de circular pelo território. Circulando (anotações de pesquisa sobre fala do mediador - aula 1 - grifos meus).

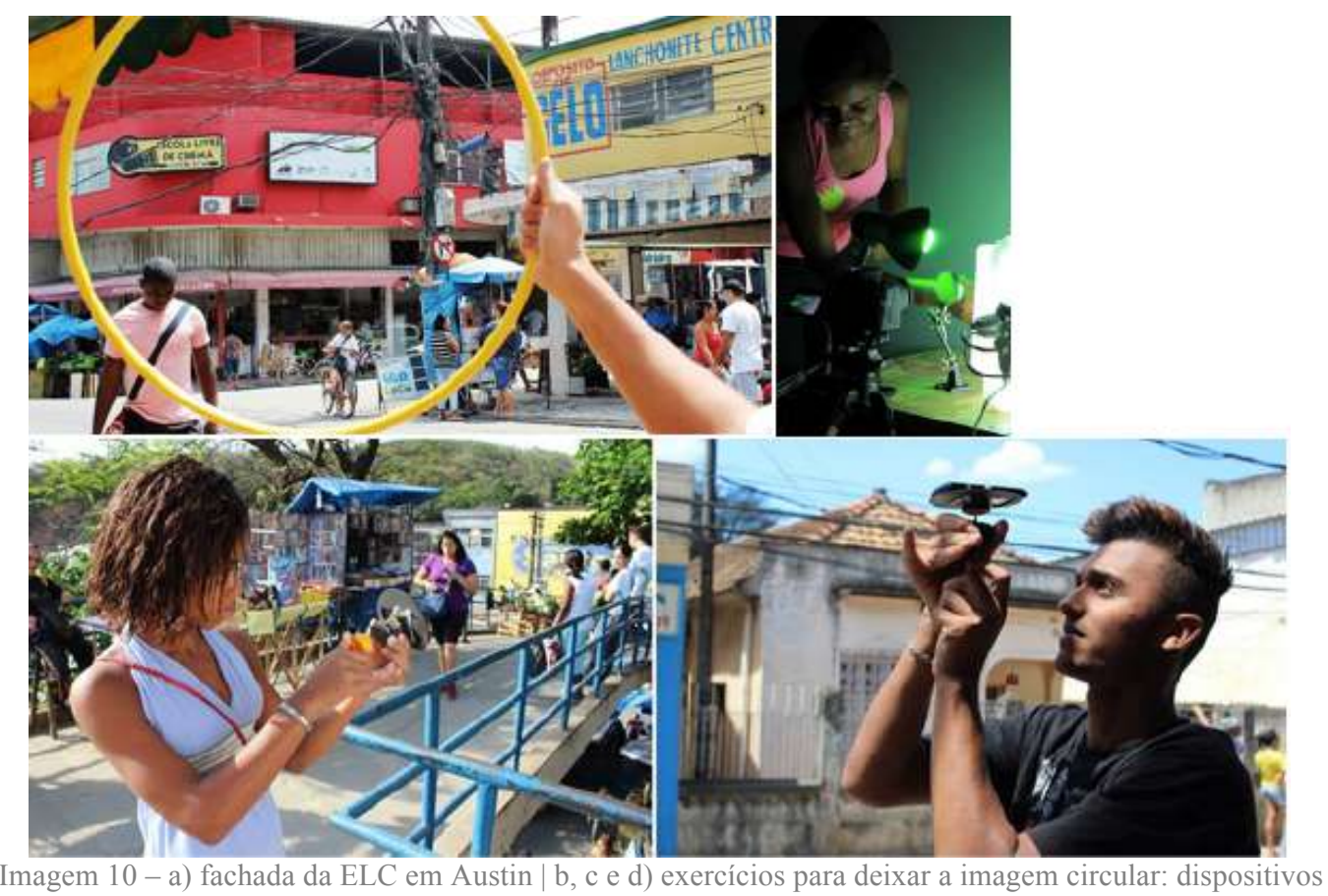

de gravação - créditos: ELC

Este vídeo que a gente tá vendo não será exibido numa tela (como vocês estão vendo), ela vai estar dentro de uma espécie de (...), sabe latão de lixo, de metal? Imagina um latão de madeira, uma espécie de barril, preto e todo fechado. Nesta tampa tem um olho mágico (como aqueles de porta). E no olho mágico você assiste a este filme, que está dentro do barril. E com o fone de ouvido para ouvir o som (mas o som não está neste vídeo ainda - o que será exibido). Na sexta-feira 
assistiremos com o som (anotações de pesquisa sobre fala do mediador - aula 1 - grifos meus).

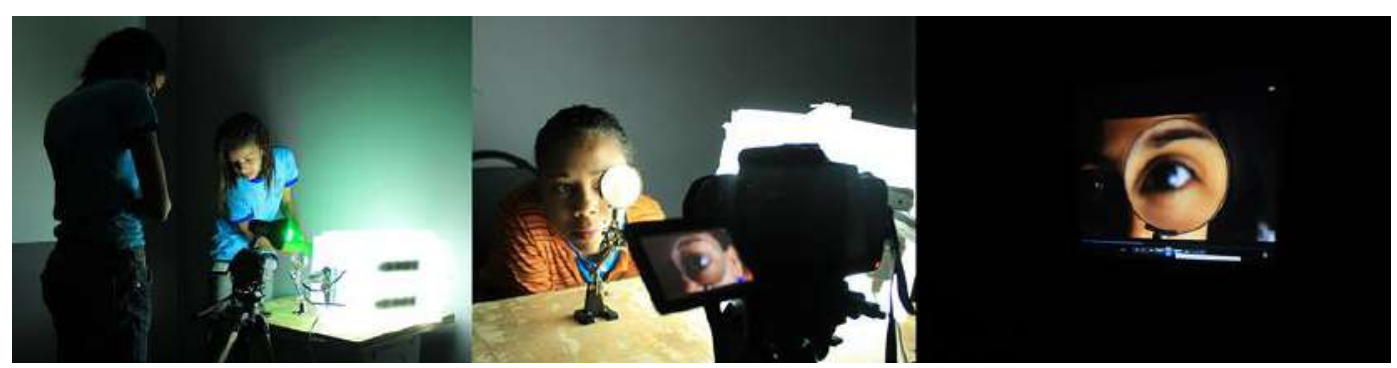

Imagem 11 - Gravação de vídeos para \#Circulando - créditos: ELC

Então, isso é uma câmera presa num eixo que gira, na verdade a gente usou isso aqui (mostra o dispositivo), a gente começou a experiência prendendo o celular aqui, colocando pra gravar e ficava andando na rua (girando o dispositivo). A gente tá sempre tentando, de alguma maneira, mudar o ponto de vista que a gente tem (anotações de pesquisa sobre fala do mediador - aula 1).

Ainda em meio à explanação sobre a forma de construir a imagem, o mediador explica como este tipo de vídeo é exibido e qual a dimensão da experiência do espectador.

Não é um vídeo exibido numa tela para todo mundo, não é necessariamente o que a gente chama de uma experiência coletiva. No cinema, vamos lá e tem uma tela e está todo mundo sentado, assistindo ao mesmo filme. Neste vídeo não, ele não tá sendo exibido numa tela grande para todo mundo ver, tem que ser visto um por um, uma pessoa por vez. Este vídeo tem 10 minutos, as pessoas muito provavelmente não ficarão 10 minutos ali, abaixadas, no olho mágico vendo esse vídeo. As pessoas vão ver trechos dele. É um experiência individual, você vai lá e assiste a um trecho do vídeo sozinho, não é aquela de ver o filme todo com todo mundo... Temos dois vídeos nesta videoinstalação (anotações de pesquisa sobre fala do mediador - aula 1 - grifos meus).

Depois de familiarizar a turma com a produção da ELC, apresentar fotos, vídeos e os dispositivos técnicos, os mediadores convidaram a turma para assistir à abertura da videoinstalação \#Circulando, que aconteceu poucos dias depois daquela primeira aula. Eles reservaram um ônibus que saiu da sede da escola, em Austin, e levou os alunos até a Escola da Palavra, que fica na Lapa, próximo ao centro do Rio de Janeiro. Eu também fui à abertura, que aconteceu no dia 22 de fevereiro de 2014 e apresento aqui algumas impressões minhas sobre aquele dia, 
no que se refere à videoinstalação e à leitura da relação dos alunos com aquele evento:

Corpos que se deslocam buscando quebrar um estranhamento, com o desejo de promover um deslocamento. É assim o olho que nos observa no vídeo projetado de dentro de um objeto cilíndrico. Lembro-me das poucas aulas que assisti em 2013.2 na ELC, em uma delas os alunos estavam refazendo os vídeos com uma lupa acoplada próxima à câmera fotográfica. Eles tentavam fazer o foco em partes do seus próprios corpos como: mão, braço, olho, nariz, boca, joelho, a textura da pele etc. A timidez de uns e a desenvoltura de outros trabalhavam em harmonia. Alguns pulavam da cadeira quando chegava sua vez de ir para frente da câmera, enquanto outros se escondiam (ou quase faziam isso). Acredito que ali aquelas crianças estavam simplesmente experimentando ou melhor, deixando-se experimentar novas formas de construir imagens (Anotações de pesquisa sobre impressões da pesquisadora - abertura da videoinstalação \#Circulando).

Naquele dia, na Escola da Palavra, os alunos do ciclo anterior, os novos alunos e os pais destes grupos compareceram para ver a videoinstalação. Para a maioria deles, esta foi a primeira experiência como espectador de uma obra neste estilo e todo clima novidade foi enfatizado quando finalmente puderam ver as imagens projetadas.

Talvez a grande surpresa da videoinstalação para os alunos tenha sido assistir aos vídeos e ouvir sua própria voz fazendo parte da trilha sonora. Pude presenciar a reação de surpresa de algumas crianças ao ouvirem suas próprias vezes saindo do headfone, eles citavam lugares do território que anteriormente exploraram. Isso também acontece porque todo processo de montagem e pós-produção é feito pelos mediadores da escola, quando os alunos já estão de férias (Anotações sobre impressões da pesquisadora - abertura da videoinstalação \#Circulando grifos meus).

Retomando a descrição da aula 1 na ELC em 2014, resgato o momento quando os mediadores apresentaram a metodologia da escola, isto é, trataram de conceitos que norteiam a forma de trabalhar adotada por eles. Na tentativa de exemplificar sua aplicação e torná-los mais próximos da linguagem dos jovens, o mediador expõe: "Aqui na escola, tudo que a gente faz tem uma base. É um tripé: a palavra, o corpo e o território" (anotações de pesquisa sobre fala do mediador aula 1). O mediador atribui à palavra a maneira de se expressar, o sotaque, a gíria; 
ao corpo, a ação desse corpo pelos lugares onde passam e ao território uma relação com o espaço, "onde a gente está". A metodologia da ELC é apresentada como sendo seu grande diferencial, fruto da experiência com os projetos desenvolvidos ao longo de sua existência, ela norteia todas as produções. Tratarei detalhadamente este tema no próximo capítulo, problematizando a metodologia da ELC.

Em seguida, ainda durante a aula 1, os mediadores apresentaram o tema que a ELC escolheu para trabalhar em 2014: a dança. Naquela aula, esta era única noção que mediadores e alunos tinham: que a dança seria explorada ao longo do semestre e com isso, sua relação com o cinema. Ainda não se sabia como desenvolver o tema ou fazer uma aproximação, mas este fato não se caracterizava como um problema, os planos eram experimentar, vivenciar o cinema a partir da sua prática, acreditando que, com isso, novas ideias surgiriam e se concatenariam.

Foram também exibidos três vídeos como referência para pensar o tema: o clipe da música "Kagado", dos Kazumbis feat Cabo Snoop, para pensar a cultura jovem, a cor das roupas, o estilo, colorido, a coreografia. $\mathrm{O}$ vídeo do espetáculo “A Deusa da Misericórdia de Mil Braços”, do ballet das dançarinas surdas, do coreógrafo chinês Zhang Jigang, chamando a atenção para a harmonia da coreografia e a sequência final do filme "Pequena Miss Sunshine", dos diretores Jonathan Dayton e Valerie Faris (2006) para pensar a dança no cinema. Por fim, os mediadores pediram aos alunos que elaborassem um abecedário com palavras que tivessem relação com a dança e que, naquele momento, vinham à memória e/ou que fossem referência para eles. O exercício foi entregue e, com isso, a escola pode mapear o repertório de cada aluno, num exercício de memória e que trouxe para o debate as escolhas de cada aluno, ações como estas eram recorrentes durante as aulas, que muitas vezes eram alimentadas por elementos subjetivos daqueles sujeitos.

Pensando no processo de criação, o primeiro dia de aula evidenciou características do fazer imagens da ELC, a forma de aproximar os alunos e envolvê-los no processo e em uma experiência com o cinema, trazendo mais questões abertas a serem resolvidas, do que um modelo pronto e elaborado de produzir imagens. Optei por detalhar os momentos desta aula no intuito de apresentar as primeiras impressões e reação dos alunos com a proposta da escola. 
A surpresa com o "novo" tipo de cinema apresentado e a curiosidade pela relação do cinema com a arte contemporânea.

Retorno agora ao título "tema e formato, sem roteiro", para explorar como o tema apresentado na primeira aula foi desenvolvido e chegou à videodança Montão de Coisa. Continuo o movimento de construção textual explorando os encontros ao longo do ano de produção.

Durante o primeiro mês de aula uma dupla de mediadores assumiu as aulas de linguagem e nos primeiros encontros trabalharam os elementos fundamentais da linguagem cinematográfica e a manipulação da câmera, sempre com exercício práticos, gravando na escola ou na rua. Nas imagens que seguem, as fotografias do primeiro exercício prático desenvolvido nas ruas de Austin: o Minuto Lumière, ao mesmo tempo percebemos a mediadora auxiliando os alunos nos ajustes técnicos e no manuseio da câmera (imagem 13).

Todas as imagens que vamos produzir aqui vão passar por essa câmera. Por isso, precisamos nos familiarizar com ela. Precisamos escolher o recorte. São recortes, são escolhas (anotações de pesquisa sobre fala do mediador - aula 4).
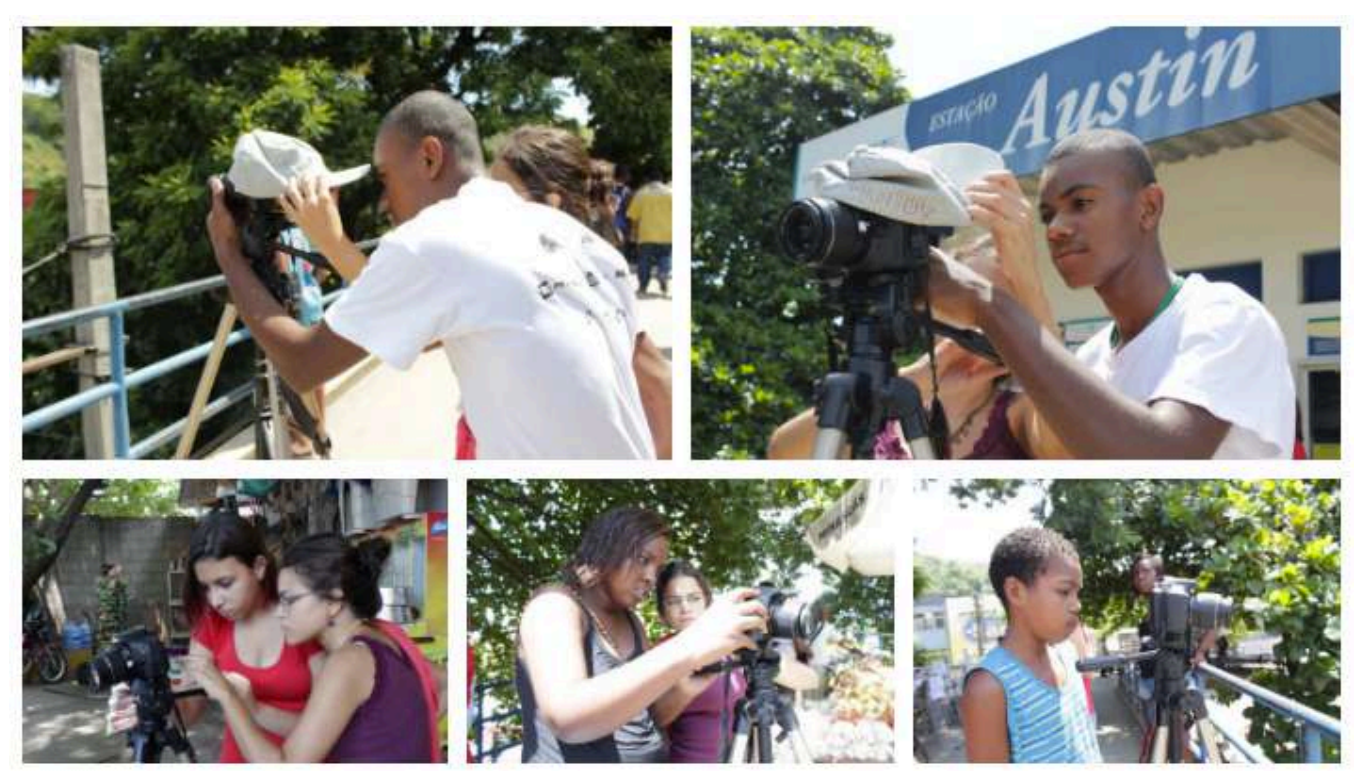

Imagem 12 - Fotos de bastidores da execução do exercício de gravação para o Minuto Lumière, centro de

\section{Austin - créditos: ELC}

Durante o primeiro semestre todas as aulas foram alternadas entre as aulas de linguagem e as aulas de cinema, corpo e dança. Dessa forma, enquanto uma dupla de mediadores trabalhava a relação dos alunos com a linguagem 
cinematográfica e a linguagem do vídeo, a segunda dupla investia no universo do corpo e da dança e a relação com a imagem em movimento.

A partir do segundo mês de aula, duas novas mediadoras assumiram as aulas que aqui nomeei de "cinema, corpo e dança". Estas aulas abordaram a parte mais conceitual do ciclo, o trabalho com a dança e o corpo, explorando o ato de filmar o corpo e observando como isso vai para a imagem.

A mediadora pede que os alunos se apresentem. É sempre um exercício de insistência fazer com que eles falem. Nome, idade, local em que moram e o que conhecem da cidade. A situação dos pais sempre aparece nas falas (trabalho, falta de tempo), o interesse pelo audiovisual. Falam ainda do último filme que assistiram.

(...)

Grande parte dos alunos demonstra curiosidade em ver o que existe no cinema além do filme - por trás das câmeras. É importante notar que alguns alunos participam de outros projetos, especialmente projetos ligados ao teatro (anotações de pesquisa - aula 8 ).

Com base nas primeiras referências de vídeo compartilhadas pela mediadora e que exploram a relação com a dança, a discussão girou em torno de:

1) Como o corpo era filmado nessa época: a relação frontal, intencional e o enquadramento fixo e integral do corpo nestes primeiros filmes de dança. 2) Essa modalidade ainda é muito usada, principalmente em videoclipe hoje, seduzir o público, olhar para o espectador. 3) Outras formas de filmar o corpo: registrando apenas partes dele podem sugerir o todo (anotações de pesquisa sobre fala da mediadora - aula 8).

Ao exibir os vídeos a mediadora sempre chama a atenção dos alunos para o movimento, enquadramento e a maneira como a câmera capturou o movimento. As referências, ao serem exibidas, são comentadas pela mediadora, explorando o contexto em que foram criadas, quem fez as imagens. Além disso, sempre solicita que os alunos descrevam a imagens, perguntando: "o que você viu na tela?".

Ao longo dos encontros a aproximação com a dança foi sendo feita gradualmente, através de experimentos e sempre ancorada num trabalho de formação do reportório ${ }^{24}$. Por volta da aula 22 a mediadora responsável pelas

\footnotetext{
${ }^{24}$ A formação do repertório será abordada na próxima subseção, nas discussões que envolvem a construção visual do filme.
} 
aulas de cinema, corpo e dança começa a pensar mais objetivamente em um trabalho específico e propõe aos alunos que isso seja feito em conjunto com eles. "Vamos fazer um filme e precisamos pensar juntos como ele será" (anotações de pesquisa sobre fala da mediadora - aula 22).

Como concluir algo que permanece em aberto? Um processo de aprendizagem é como uma embarcação cuja meta é a volta ao mundo. Um caminho em aberto, sujeito a pausas, tropeços e reverberações. Pelo olhar cativo de cada aula, Austin foi catalogada em imagens, filtrando gestos, cores, sensações, discursos... O repertório desta coleção tomou jeito de corpo, de grupo, de criança querendo ser grande. A coleção virou seleção, repetição, debate, dança e poesia (Montão de Coisa, folder de apresentação - grifos meus) .

“Como seria um catálogo de materialidades de Austin, do território?", pergunta a mediadora durante o planejamento para o vídeo. Agora já estávamos no início do segundo semestre, os encontros semanais na ELC estavam de volta e a primeira notícia foi: "Faremos um filme. A gente vai filmar. Vamos fazer uma produção cinematográfica, vamos editar, montar, ter um trabalho como resultado final do nosso ano letivo aqui na escola" (anotações da pesquisadora sobre fala da mediadora - aula 36). De imediato a proposta apresentada soou um tanto pretenciosa para os alunos, "daria Austin um catálogo de imagens? Será?", questionou um dos alunos presentes. Mesmo sem ter ideia de como esta proposta seria viabilizada e por vezes duvidando da sua real possibilidade de execução, os alunos embarcaram e aceitaram o desafio no momento da proposta.

Montão de coisa (2014) nasceu de um catálogo de imagens de Austin feito pelas turmas de videoarte. O exercício que deu origem ao catálogo foi divido em etapas em que alunos e mediadores assumiram o papel de coletores, colecionadores e catalogadores de imagens daquele território. A videodança é resultado de uma experiência que explorou ao longo do seu processo a relação entre a câmera, o corpo e a dança, em um processo de escritura pautado também no território. 


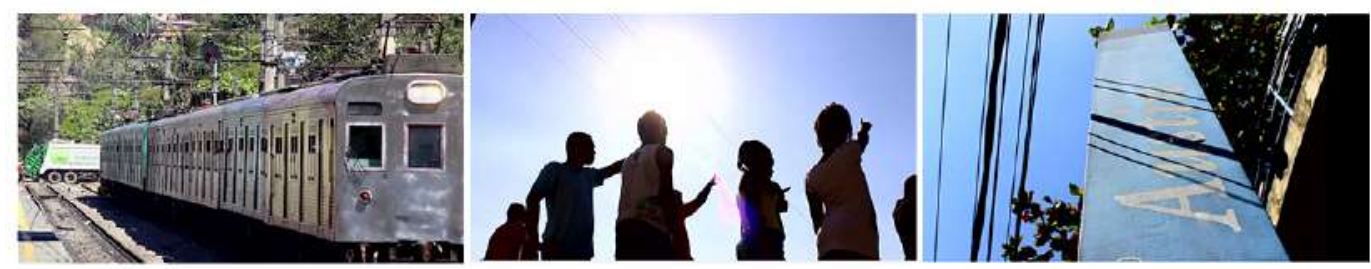

Imagem 13 - Frames iniciais do vídeo Montão de Coisa - créditos: ELC

O trabalho de aproximação desenvolvido durante o primeiro semestre constituiu uma base importante no trabalho de criação da videodança e como forma de fechar uma etapa para passar à outra a mediadora da aula de cinema, corpo e dança começou o segundo semestre resgatando os momentos mais emblemáticos na experiência vivida ao longo dos primeiros meses. $\mathrm{O}$ exercício funcionou inicialmente como uma retrospectiva, uma viagem no tempo, a partir de três questões:

1) O que marcou (cada um) neste período que ficamos juntos, podendo ser um filme, uma aula específica, um acontecimento, uma passeio... 2) Por que você está aqui, qual o interesse, a motivação para continuar no grupo, na ELC? 3) O que te interessaria desenvolver na aula, podendo ser uma técnica específica, um assunto falado na aula, ou algo que ainda não tenha sido visto (anotações de pesquisa sobre fala da mediadora - aula 29).

As respostas citavam os exercícios feitos ao longo das aulas, filmes e referências, especialmente os filmes experimentais e os vídeos da videoarte, pela possibilidade de assistir vídeos que estão fora do circuito comercial. $\mathrm{Na}$ imagem a seguir, um fragmento de um exercício de sondagem feito em sala, a resposta foi escrita por um aluno da turma $\mathrm{C}$ (que acompanhei). Na resposta temos pistas do encontro com o cinema vivenciado através da experiência com a escola.

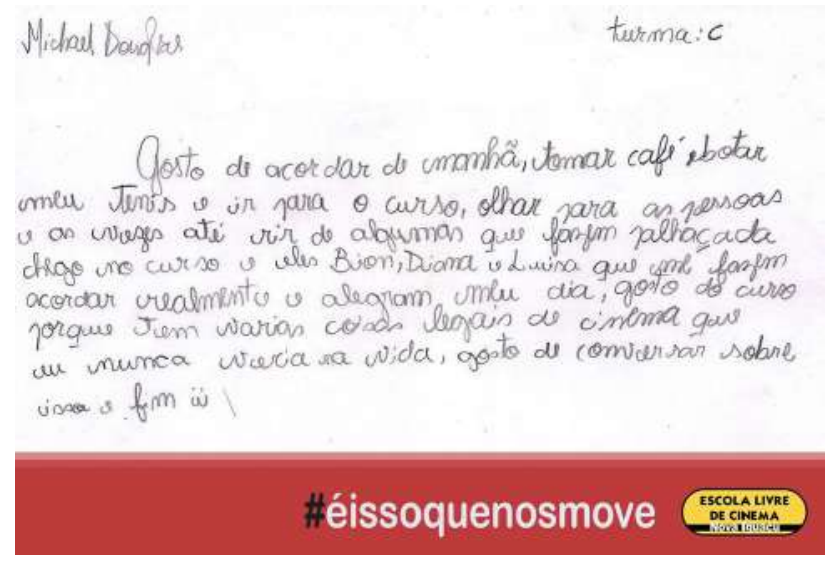

Imagem 14 - Fragmento do exercício de sondagem com os alunos da turma $\mathrm{C} \bullet$ créditos: ELC 
O projeto que deu origem à videodança Montão de Coisa foi apresentado à turma como Projeto Remix, este nome temporário faz menção à palavra mix, de misturar, mesclar, amalgamar, combinar as coisas que foram trabalhadas durante as aulas até ali. A ideia surge do princípio de colecionar coisas, "vamos colecionar gestos, materialidades, cores, sensações, sentimentos, objetos, seres vivos, animais, plantas. A partir da próxima semana, a cada semana a gente vai fazer uma parte do nosso catálogo de coisas" (anotações de pesquisa sobre fala da mediadora - aula 36). Durante a apresentação do projeto os mediadores explicaram o que seria esta "coleção de coisas":

Vamos catalogar este território aqui. A gente vai chegar a um livro de coisas. O livro das coisas que essa turma coleciona. $\mathrm{O}$ que é muito interessante: outras turmas terão outros livros de coisas e a gente vai poder comparar isso, vamos ver o quão diferente talvez seja a coleta deles e a nossa. Vamos poder comparar isso, eu acho que vai ser bem diferente (anotações de pesquisa sobre fala da mediadora - aula 36).

O catálogo é apresentado como um livro ou folhas com objetos semelhantes, funciona também como uma forma de definir aquele território e demarcar o que ele foi no passado, de onde ele veio e dar indícios do que venha a ser. Para exemplificar isso os mediadores utilizaram um exemplo comum ao universo dos alunos (resultado das aulas de geografia): “existem catálogos de coisas, por exemplo, como um catálogo de plantas da região amazônica, é um trabalho infinito, tá sempre em construção. O trabalho da pessoa que vai catalogar isso é riquíssimo" (anotações de pesquisa sobre fala da mediadora - aula 29).

Por que isso interessa pra gente? Porque a gente tá dialogando com o território, tudo que venho apresentando pra vocês tem relação com o território, inclusive quando a gente falou de gestos. Catalogar gestos é riquíssimo, porque os que a gente colecionaria aqui em Austin, provavelmente não vai ter em outro local. Se a gente for pra Zona Sul do Rio, vamos ver gestos totalmente diferentes (anotações de pesquisa sobre a fala da mediadora - aula 36).

Esta fala da mediadora me fez lembrar uma conversa que tive pelos corredores da ELC com um dos mediadores da escola. O mediador me falava sobre os tempos em que a sede da escola ficava no Bairro de Miguel Couto, outro 
bairro de Nova Iguaçu, e como percebia que a dinâmica, os gestos e paisagem de Austin eram totalmente diferentes de Miguel Couto, mesmo se tratando de bairros da mesma cidade.

Debateu-se o catálogo como um registro do momento em que a turma e a escola estão vivendo, a mediadora falou também das singularidades de cada momento numa cidade ou em um bairro para as pessoas que moram ali ou que possuem parte do seu cotidiano naquele território.

Isso não vai se repetir, nem outra turma terá um catálogo como o nosso, nem ano que vem, numa turma seguinte, se este trabalho fosse feito anualmente, ele não seria parecido. É o catálogo deste momento e isso envolve as nossas afinidades, nossos interesses, tudo vai se constatar no que a gente vai colecionar a partir de agora. É um exercício, se avaliar, lembrar do que fizemos até agora (anotações de pesquisa sobre a fala da mediadora - aula 36).

Podemos pensar então que este processo de dar forma, de criar "algo novo" a partir das coleções e dos catálogos passa pela capacidade de compreender e esta, por sua vez, pela capacidade de ordenar, configurar e significar (OSTROWER, 2004, p. 9). A mediadora procura fazer com que os alunos entendam isso de forma prática, durante a experiência, "eu queria que vocês observassem o vídeo com esse olhar de colecionador, seria um pouco, como cientista maluco: que começa a pegar coisas e fazer relação" (anotações da pesquisadora sobre a fala da mediadora - aula 36), explica.

Eu vou explicar um pouco pra vocês sobre os itens da nossa coleção e a gente vai fechar isso, este material todo. Vamos revisitar, para então transformar. Então, o ideal é que todo mundo venha, que todo mundo participe, até chegar as filmagens. Até lá tudo já vai estar pronto, as coleções, a coreografia, quem vai fazer o que... vai tá tudo organizado (anotações da pesquisadora sobre a fala da mediadora - aula $36)$.

Durante o trabalho de coletar imagens os alunos foram para a rua a cada encontro, com um tema diferente, o que resultou em cinco coleções: seres vivos (bichos e plantas), materialidades, grupos sociais, sensações e sentimentos e gestos. A ideia era que as coleções feitas semanalmente formassem a base do projeto e a partir do material das coleções fosse criado um catálogo e assim, 
criados os cenários, compostos os figurinos e os objetos em cena fossem escolhidos.

Desta forma, quando o exercício de "colecionar coisas" começou na ELC, os alunos tiveram que se dividir em dois grupos e sair pelas ruas do bairro de Austin, observando o local e anotando onde poderiam encontrar as imagens para sua coleção. No final da observação a pequena lista de "locais possíveis" era percorrida, eles pediam autorização para gravar (caso fosse necessário) e revezavam-se entre as filmagens, que foram feitas da seguinte forma: cada um dos alunos que fazia parte do grupo responsável pela filmagem capturava 30 segundos de imagens, os ajustes na câmera e as dúvidas técnicas eram tiradas na rua, numa conversa com o mediador que estava acompanhando a gravação. Neste exercício o momento da gravação e o movimento de câmera eram escolhidos pelos alunos. Ao coletar essas imagens eles estavam na verdade, fazendo o primeiro esboço do vídeo previsto para o final do semestre e vivenciando uma experiência de criação, um canal em que processos subjetivos, individuais e coletivos se desenvolveram.

Quando retornavam para a sala, as imagens eram transferidas das câmeras para o computador, todos assistiam e avaliavam o material bruto, surgiram debates em torno de questões técnicas e de linguagem, assim como muitos compartilhavam o que havia acontecido na rua naquele dia. O objetivo inicial era colecionar e, com isso, estabelecer relações entre o que eles estavam vivendo ali e o que já haviam experimentado na escola, com o cinema e o com o cotidiano de cada um.

Desta forma, resgato uma nota de pesquisa feita por mim durante o trabalho com a coleção de imagens de seres vivos, primeiro dia de gravação desta etapa:

O objetivo da saída, além de alimentar o imaginário de colecionadores, é dar a cada um a possibilidade de registrar usando a câmera e perceber sutilezas e dificuldades de se filmar na rua. Outro ponto percebido na saída foi que para filmar uma pessoa temos que primeiro pedir a permissão o que tornou maior a responsabilidade do grupo, que se mostrou mais empenhado em executar suas filmagem e se relacionar com os "objetos" a serem captados (anotações de pesquisa sobre impressões da pesquisadora - aula 38).

Durante a avaliação das imagens, feita em sala, especialmente durante os primeiros vídeos, os mediadores sinalizaram que alguns deles apresentavam 
problemas técnicos, como "luz estourada", imagem fora de foco etc, fazendo com que algumas coleções precisassem ser refeitas. Pude observar que esse episódio é recorrente na experiência de criação da ELC. O exercício acabou passando pelo mesmo fluxo dos exercícios feitos ao longo do semestre e também em outros projetos da escola. Esse fluxo, comum aos exercícios, não se configura como um episódio negativo, mas sim como parte do processo, da experiência e dos experimentos permitidos. Apresento a seguir (figura 1) um esquema de como os exercícios são trabalhados pela ELC, desde apresentação conceitual em sala de aula até as imagens criadas:

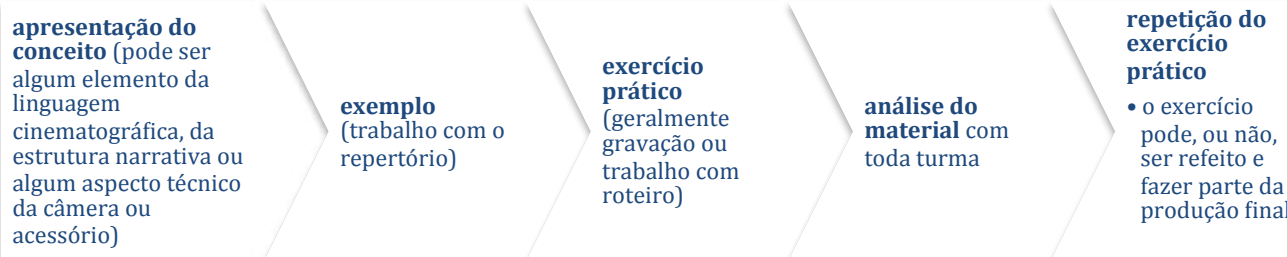

exemplo

\subsubsection{Gestos para uma coreografia}

Quando a dança é captada pelo olho da imagem, ela ganha uma outra existência (SPANGHERO, 2003, p. 38).

Dentre os objetivos explícitos durante o processo de criação das coleções de imagens de Austin, um deles era que estas seriam importantes peças na composição visual e na criação da coreografia da videodança. Até a finalização desta etapa, os alunos e mediadores analisaram reiteradas vezes os vídeos feitos na rua, discutindo aspectos técnicos e conceituais. O estudo destes vídeos foi essencial para aquele momento de criação, no sentido de ter conduzido a tradução das imagens em gestos, que posteriormente viraram uma coreografia.

Ao chegar neste ponto do processo, em meio a momentos de seleção e escolhas, a mediadora fez um resgaste das aulas do primeiro semestre quando 
trabalhou detalhadamente o que seria o gesto e o corpo no universo da videodança e da videoarte. Este tipo de movimento pontuava as escolhas estéticas e de linguagem feitas por alunos e mediadores através dos exercícios práticos, além de ter sido um fio condutor na tentativa de alinhar a produção das 4 turmas de videoarte, que trabalhavam simultaneamente, porém com mediadores diferentes para as aulas de cinema, corpo e dança.

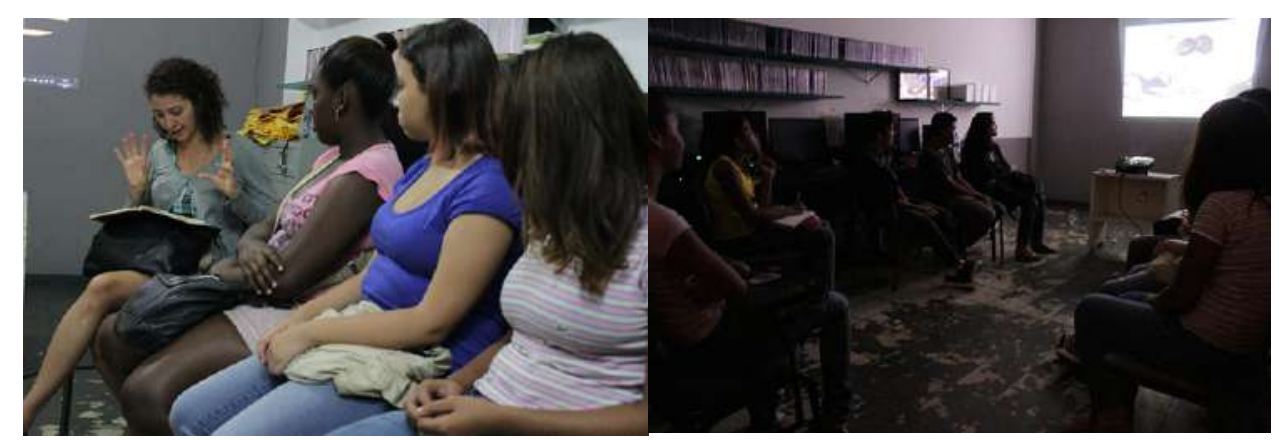

Imagem 15 - Mediadora em sala com os alunos - aula 22 - créditos: ELC

Durante as aulas, o objetivo tem sido mostrar aos alunos recursos, técnicas e novas abordagens cinematográficas através da videoarte, com o intuito de expandir seus interesses. A partir disso a mediadora filtra e afunila os assuntos trabalhados para pensar junto com os alunos o tema, os métodos e os formatos que serão desenvolvidos. Existe sempre um esforço, especificamente nas aulas de cinema, corpo e dança de trabalhar objetivamente (anotações da pesquisadora - aula 22).

$\mathrm{Na}$ aula 22 (fazendo um resgate do primeiro semestre) as noções de videoarte e videodança foram abordadas a partir de 3 perguntas: o que é dança? $\mathrm{O}$ que é arte? O que é tempo? Em seguida, foram pontuados alguns filtros históricos para reforçar a experiência do movimento. Naquele encontro os alunos tiveram contato com nomes como Maya Deren, Peter Campus e Norman McLaren. Os encontros seguintes abordaram como tema "O gesto e sua percepção: ângulo, gravidade, duração, relação" (aula 24), que discutiu o limite/abertura dos signos gestuais, os deslocamentos dos sentidos na recepção do gesto do outro (como a ação do outro me afeta) e introduziu o assunto de planos, duração para realização e qualidade gestual. Como prática, os alunos foram envolvidos nas seguintes atividades: 
1. Roda de gestos: consistiu em fazer um gesto que seria repetido por todos, um após outro. A ideia foi trabalhar a percepção da qualidade do movimento do outro, da intensidade, da duração e conseguir repeti-lo tal qual. 2. Acumulação de gesto: uma primeira pessoa fez um gesto, a pessoa seguinte repetiu esse primeiro gesto e adicionou outro. Uma terceira pessoa repetiu os dois primeiros gestos, adicionando outro e assim por diante. 3. Foram criados 3 grupos. O grupo 1 tinha que inventar uma historia e contá-la através de 4 gestos. Os outros 2 grupos observavam, de posicionamentos diferentes no espaço, e depois contavam sua interpretação. Por fim, foi feito um revezamento dos papéis (anotações da pesquisadora - aula 24).

Ainda com foco nos gestos, foram recuperados os assuntos abordados nas aulas $26,29,30,32$ e 34 , cujos temas e títulos trago a seguir. $\mathrm{Na} 26^{\mathrm{a}}$ aula, tratouse do gesto do contexto, o contexto do gesto: como um gesto significa?

Neste encontro a mediadora trabalhou a relação entre gesto e palavra, discutindo sobre a inter-relação entre a palavra, a ação gestual e a não suficiência da palavra falada para objetivar seu conteúdo. Abordou a liberdade semântica dos conteúdos gestuais e como estes conteúdos variam suas representações formais de acordo com o contexto e o observador. A mediadora utilizou um exemplo a partir de um gesto comum como "dar tchau", cruzar os braços e esfregar os dedos. Partindo da pergunta: como pode um gesto significar? (anotações da pesquisadora - aula 26).

O objetivo da aula 26 era provocar uma leitura de gestos mais aberta, descritiva e inventiva. Ao invés de perguntar "o que significa este gesto?", a mediadora motivou a leitura do desenho que uma ação gestual tem, qual a relação que se cria, quais as linhas de força, o peso, sem esquecer de onde se vê o que está acontecendo e como se vê. Como proposta de atividade os alunos analisaram a pintura A criação de Adão, feita por Michelangelo.

Ao trabalhar "tema, assunto e problema" (aula 29), a mediadora conversou com os alunos sobre o que é um tema/assunto num filme e como podemos identificá-lo. Foram apresentados trechos de vídeos que já haviam sido vistos na ELC (durante outras aulas), na tentativa de identificar quais seriam os temas de cada um e a partir daí a mediadora colocou a palavra "problema" tentando abordar como pode surgir um problema a partir de um tema. E como cada autor/diretor tenta solucionar seu(s) problema(s) cinematograficamente. Como exercício prático a turma foi dividida em grupos, onde em seguida a mediadora pediu que 
os alunos escolhessem um tema, identificassem um problema para ser resolvido e defendessem esse projeto para turma: "por que queremos falar disso dessa forma?"
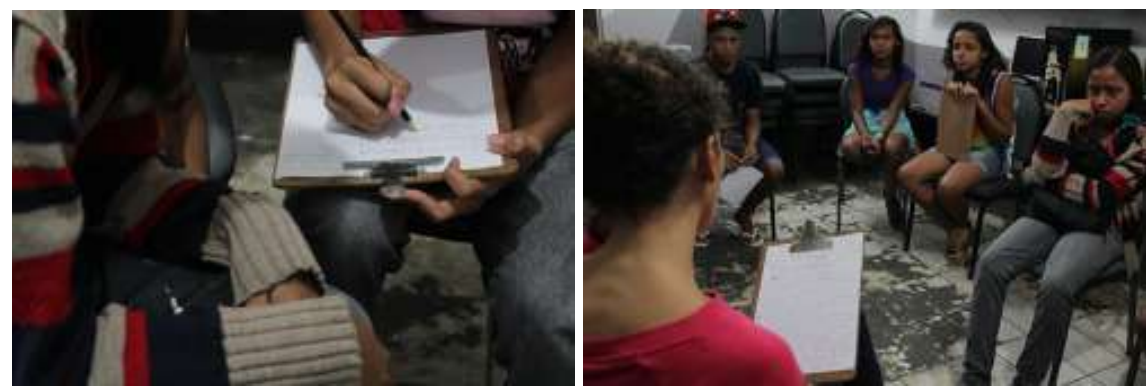

Imagem 16 - Desenvolvimento de exercício prático • créditos: ELC

Gestualidade como suporte estético foi o tema das aulas 30 e 32. Entre outros questionamentos, a mediadora provoca perguntando: como a gestualidade escolhida é suporte estético para uma temática? Como realizar um gesto diante do assunto que queremos tratar? Além disso, alguns elementos destacados para pensar o gesto em um contexto dramatúrgico: efeito, duração, ritmo, transição e intenção/ sugestão. A mediadora mostrou um vídeo feito por um aluno e pediu que os alunos identificassem o tema, um problema suscitado pelo assunto, qual foi a gestualidade trabalhada e de que forma. Como exercício, ela propôs a observação do gesto a partir de duas referências em livros: obras de Caravaggio e fotografias de peças da Pina Bausch. Em grupos os alunos se debruçaram sobre estas imagens focando nos gestos e seus elementos. Assistimos dois trechos de duas coreografias da Pina Bausch: Sagração da Primavera e Café Müller e em seguida "O baile", de Ettore Scola (1983), em seguida foi feito um debate a partir das questões trabalhadas na última aula e houve um esforço na tentativa de tentar entender que tipo de gestualidade é construída e como ela se torna discurso.
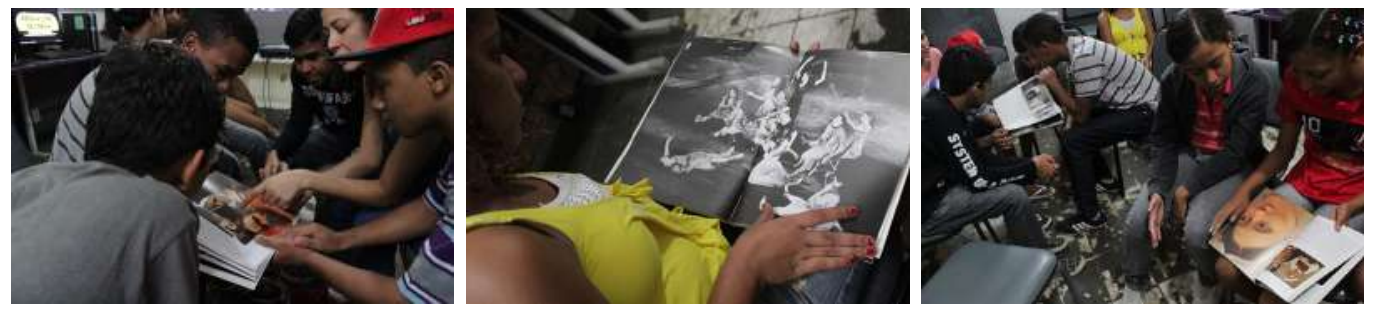

Imagem 17 - Exercício de observação, aula 30 • créditos: ELC 
Desta forma, quando a turma $\mathrm{C}$ iniciou o trabalho de tradução das imagens em gestos, utilizando listas, revendo gravações, retomando referências e pensando nas metáforas que as cenas cotidianas das ruas de Austin possibilitavam, eles trouxeram para a mediadora relatos sobre a experiência vivida durante a visita de um convidado que ministrou a aula $34,{ }^{25}$ sobre a execução e manipulação de gestos. Naquele encontro, o mediador ajudou os alunos a terem dimensão do quanto o gesto é trabalhando e repetido em um espetáculo, ele usou o filme "O baile", de Ettore Scola para incentivar o exercício de fazer listas de gestos.

Os alunos assistiram trechos do filme e fizeram listas dos gestos que observaram. Depois conversaram sobre a manipulação de gestos, a partir da interação com outras pessoas, através de um exercício prático. O mediador levou os alunos para uma sala maior e sem cadeiras, dividiu a turma em pequenos grupos, pediu que cada pessoa executasse um gesto (ainda com base no filme assistido) e em seguida que os alunos interferissem no gesto um dos outros. A prática experienciada neste exercício reapareceu no processo de criação de Montão de Coisa no momento em que os gestos foram agrupados, para então formar a coreografia.

\footnotetext{
${ }^{25}$ A aula 34 foi ministrada por um ator convidado para falar sobre gestualidade.
} 


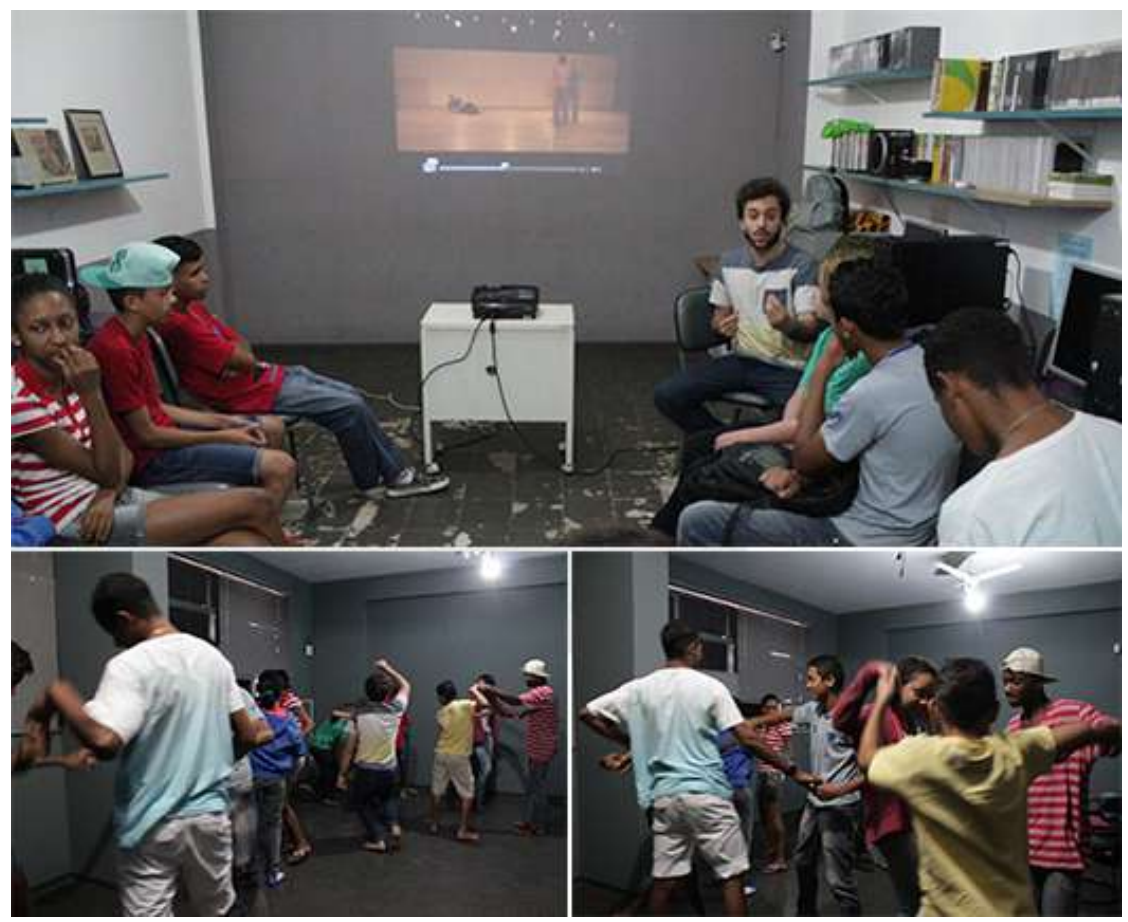

Imagem 18 - Aula 34: execução e manipulação de gestos - créditos: ELC

Na etapa de criação dos gestos para a coleção, individual e em grupo, os alunos que não tinham uma frequência nas aulas, apresentaram dificuldade para elaborar os gestos e incorporá-los ao grupo, desta forma, a saída encontrada foi criar listas de gestos, agrupá-los e defini-los como parte da coreografia, desta forma, os alunos faltosos se apropriaram dos gestos já elaborados pelos colegas mais assíduos.

Ainda nas aulas 36 e 37, durante a apresentação do projeto, os mediadores retomaram a discussão sobre a importância do repertório no processo de criação e apresentaram duas referências, que dentre as várias discutidas ao longo do curso, serviram como base para a videodança, especialmente pelo processo criação de cada uma destas. A obra de Arthur Bispo do Rosário foi apresentada aos alunos como referência para pensar a ação de colecionar coisas e catalogá-las, como trabalhar cores, formas, objetos e com isso criar categorias. Ao longo da explanação foram apresentadas fotos do centro de Austin, a todo momento os alunos foram incentivados a fazer um paralelo entre estas fotos e a obra de apresentada. Os mediadores responsáveis pela aula de linguagem trataram com mais detalhes a relação entre as coleções a serem feitas e as coleções feitas por Bispo. 


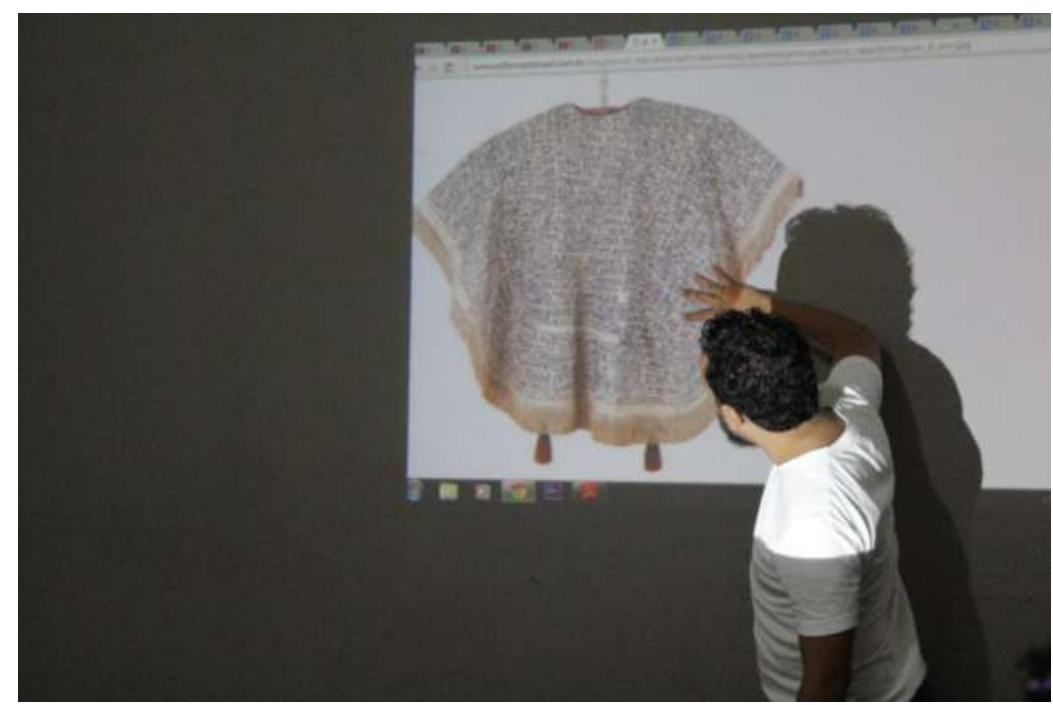

Imagem 19 - Apresentação de referências para o videodança final • créditos: ELC

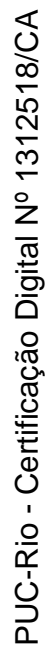
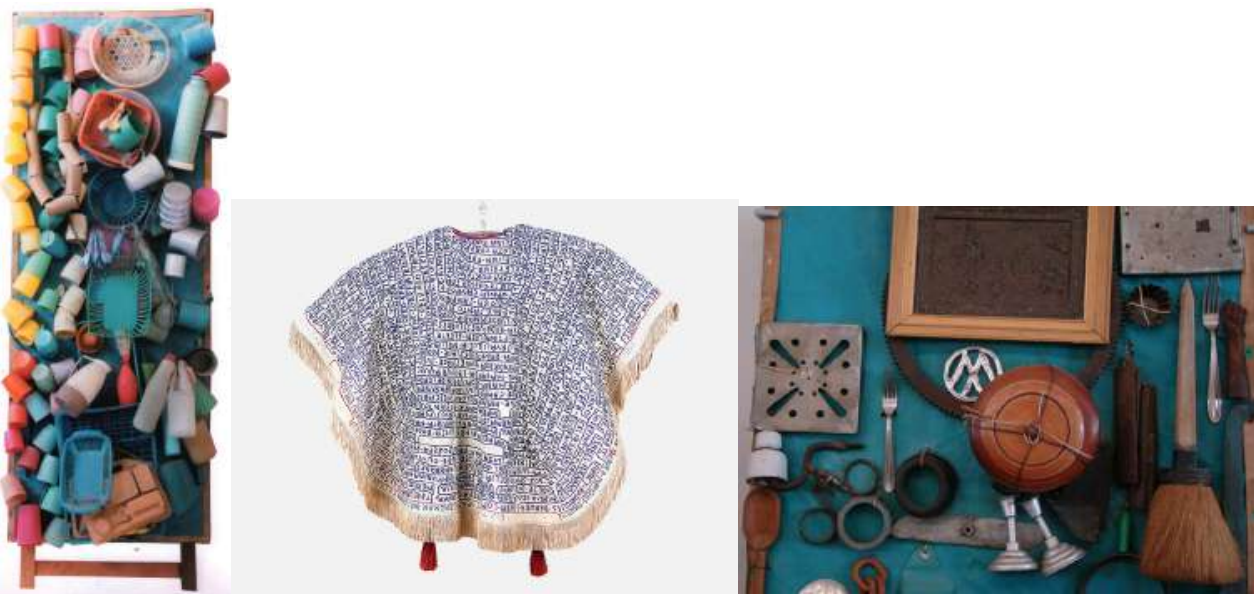

Imagem 20 - Obras apresentadas Bispo do Rosário: utilizadas pelos alunos e mediadores da ELC para pensar como agrupar objetos e fazer relações - créditos: Museu Bispo do Rosário
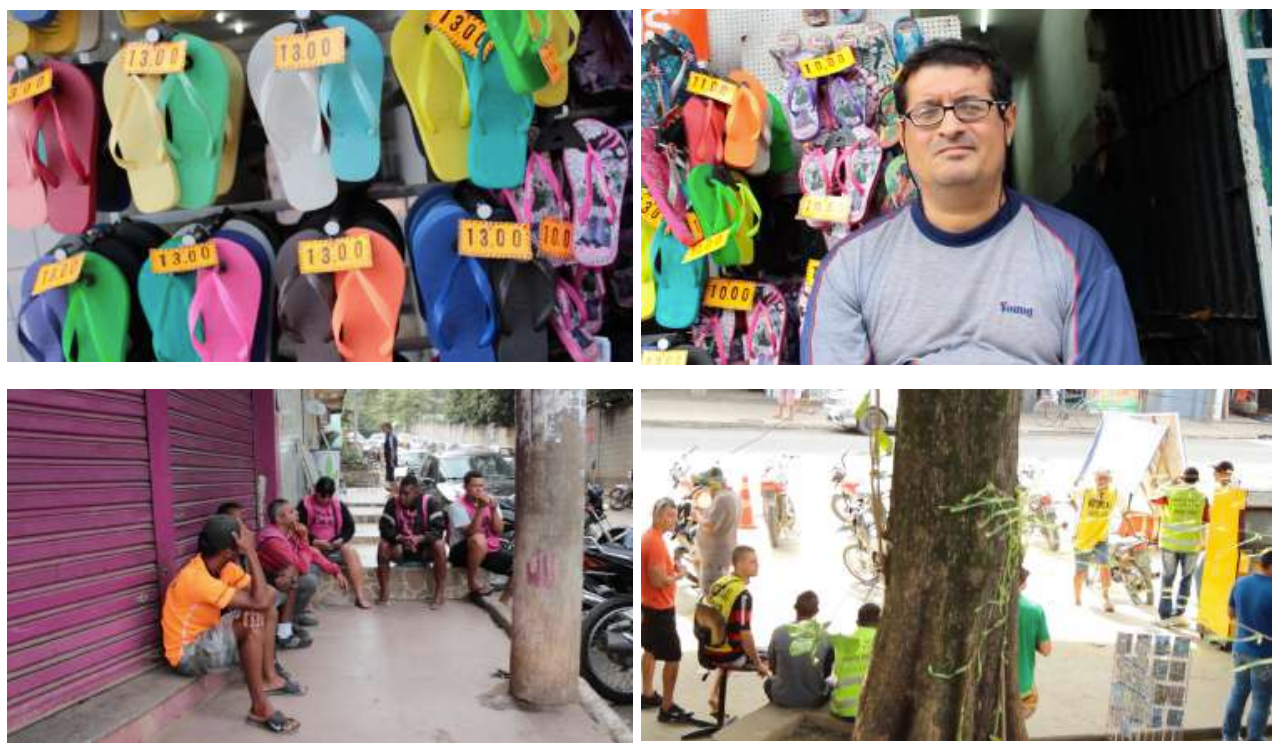

Imagem 21 - Frames da coleção de materialidades: padrões catalogados pelas ruas de Austin - créditos: ELC 
Para o trabalho de criação da coreografia, a partir das coleções, os mediadores apresentaram como referência o projeto Re:Rosas, da coreógrafa Anne Tereza De Keersmaeker. O projeto foi apresentado a turma pela mediadora responsável pelas aulas de cinema, corpo e dança, que traduziu os vídeos explicativos do site da coreógrafa belga. Encontramos referências a este projeto no desenvolvimento da videodança, na escolha pelo uso das cadeiras durante a coreografia e nos movimentos de câmera, quando somos guiados por estes objetos, que caminham entre os alunos durante a execução da coreografia, e como compõem visualmente a base da coreografia (anotações da pesquisadora sobre a fala da mediadora - aula 36). Com Re:Rosas os alunos aprenderam a pensar a coreografia de Montão de Coisa para a câmera, pensando os movimentos da coreografia com os movimentos da câmera.

Observem como ela compõe os personagens, como aparece a coisa da coleção: as cores, uma gama de cores que se fecha, marrom, gelo, amarelo. Tem muita coisa do reflexo, o vidro, a janela. É um trabalho de coleção, tem corpos que se parecem, a mesma faixa etária, uma coleção de mulheres, das materialidades, como o vidro (anotações da pesquisadora sobre a fala da mediadora - aula 36).
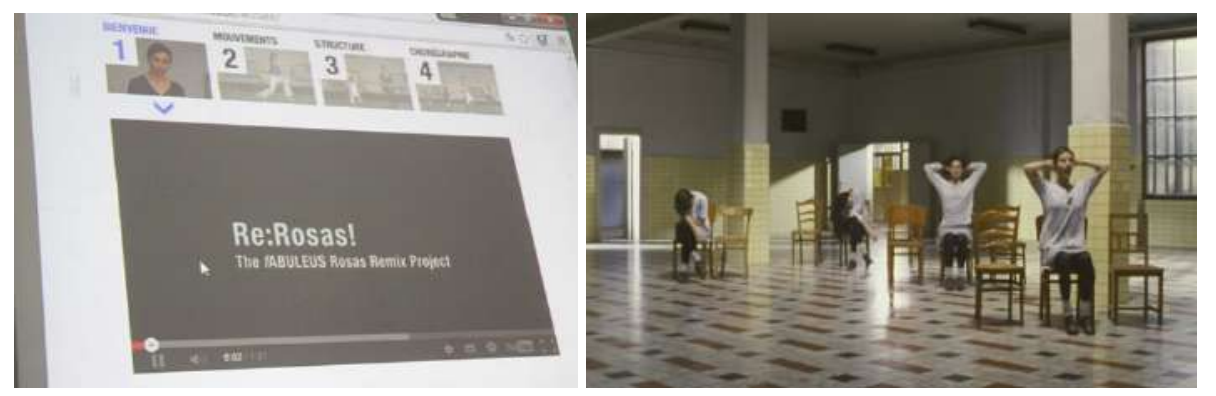

Imagem 22 - a) apresentação do projeto Re:Rosas | b) Frame de Rosas danst Rosas

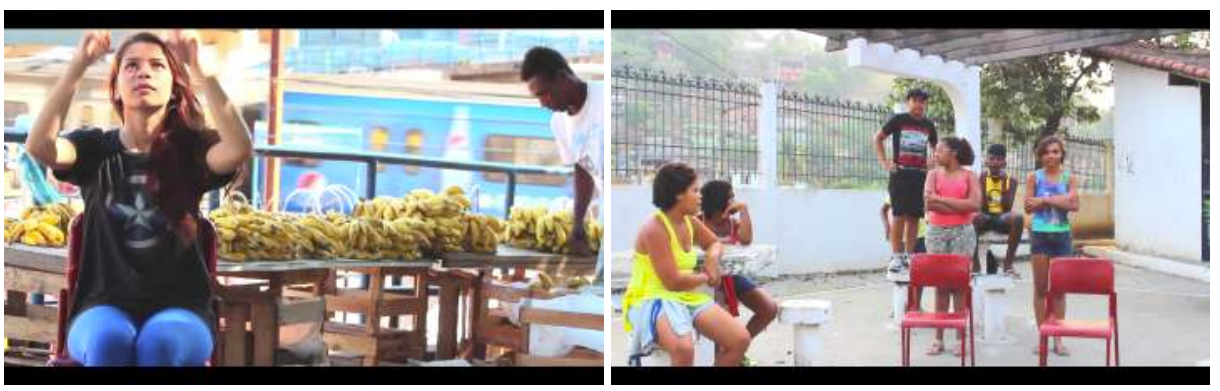


Em paralelo às aulas que trabalharam mais com a construção conceitual da videodança, a criação e a manipulação dos gestos para a coreografia, os mediadores também investiram na criação visual do projeto. No momento inicial a ideia era que a coreografia final de Montão de Coisa fosse gravada fora de Austin, esta foi uma tentativa de trabalhar em um lugar maior e com mais recursos técnicos para a gravação, os mediadores chegaram a citar que esta gravação possivelmente fosse feita em um ponto de cultura, como a Arena Carioca Jovelina, no bairro da Pavuna, no município do Rio de Janeiro. Mas a ideia de trabalhar com locações e gravações fora do território de Austin, não foi viabilizada por falta de recursos financeiros, fazendo com que o projeto fosse totalmente gravado em Austin.

Para entender a construção visual da videodança feita pela ELC é preciso retomar ao que a escola usou como referência ao longo das aulas, são obras dos mais diversos campos da arte e através delas é possível perceber o percurso feito por mediadores e alunos. Estas obras foram apresentadas ao longo dos encontros, não só com o objetivo de trabalhar as referências visuais do projeto, mas especialmente de trabalhar a formação de um repertório com os alunos, com isso entramos agora na questão da transmissão do cinema, do que foi transmitido durante os encontros.

"Só o desejo instrui" (BERGALA, 2008, p. 78). Bergala trata da transmissão do cinema e da formação do reportório através de uma aproximação do cinema como arte, em seu livro, o autor traça seus argumentos sobre a importância de fornecer um capital de filmes capazes de "construir uma alternativa ao cinema de puro consumo" (2008, p. 91). O encontro dos alunos com um cinema "alternativo" começou no primeiro dia de aula. Naquele encontro "um outro" cinema possível foi apresentado e a partir daí a formação do gosto foi trabalhada paulatinamente. Neste processo enfatizo ser importante considerar que os encontros na ELC foram ministrados por mediadores formados em escolas de cinema ou projetos semelhantes, são cinéfilos que fazem parte de cineclubes pela cidade de Nova Iguaçu, mediadores cuja formação do gosto passou pela militância utilizando o audiovisual como frente, pela experiência de produção de vídeos em contextos coletivos e pelo reportório formado entre os debates nos cineclubes.

$\mathrm{O}$ anexo 3 desta tese apresenta a lista de vídeos, filmes e referências trabalhadas durante o ano na ELC, nele podemos perceber como a relação com a 
dança foi explorada desde os primeiros encontros e como a concepção visual do vídeo foi construída, no que se refere a obras usadas como referências. Apresento aqui os momentos e referenciais mais representativos neste processo e que deram acesso a experiências diferentes das vividas anteriormente pelos alunos através do cinema. Neste sentido foi comum ao longo de cada exibição (ou na maioria delas) ouvir comentários que denotavam um estranhamento dos alunos com a obra exibida e que eles nem imaginavam que existisse.

- O que vocês acharam deste filme? Pergunta a mediadora depois da exibição do filme Alma no Olho, de Zózimo Bulbul.

- Esquisito. Responde um dos alunos.

A transmissão do cinema na ELC passa pela transmissão do filme observando, na maioria das vezes, seus aspectos de construção, a forma como o diretor fez uso da linguagem, da técnica, de como a temática é desenvolvida e, de modo geral, através de uma abordagem das questões simbólicas, deixando margem para encontros possíveis com o filme. Neste sentido, durante as aulas de linguagem os mediadores trabalharam um filme específico durante vários encontros, trata-se Deixa Voar (Cadu Barcellos, 2010), do projeto 5x favela agora por nós mesmos, abordando os vários aspectos citados. Ao mesmo tempo outras obras foram apresentadas, especialmente do universo do videoclipe, com o objetivo de fazer uma aproximação com o universo da dança. A ELC não trabalha com um material didático sistematizado, os alunos não recebem apostilas ou qualquer tipo de material impresso e, como já foi citado, os encontros são planejados em reuniões semanais entre os mediadores. Mas é importante citar que depois de uma certa altura, meados de setembro, os mediadores de linguagem começaram a trabalhar esporadicamente com o material do projeto Inventar com a diferença $^{26}$ para trazer novamente os aspectos fundamentais da linguagem cinematográfica. Neste caso, questões como plano, movimento de câmera e

26 O Inventar com Diferença é um projeto desenvolvido pelo departamento de cinema da Universidade Federal Fluminense e a Secretaria de Direitos Humanos da Presidência da República, o projeto trabalha com cinema e direitos humanos em várias escolas pelo país. Todo seu material de apoio a para o trabalho com o cinema está disponível em: http://www.inventarcomadiferenca.org/ (último acesso em 19 de fevereiro de 2017). 
enquadramento eram revistos por meio de fragmentos dos filmes e nenhum destes fragmentos foi retomado através da exibição do filme completo.

Durante as aulas de cinema, corpo e dança a mediadora programou os encontros trabalhando com a apresentação de nome importantes (pelas suas obras) no universo da videoarte e da videodança, entre eles:

- Screen tests (Andy Warhol),

- Mobile Men (Apitchatpong Weres)

- Three Transitions (Peter Campus)

- Neighbours (Norman McLaren)

- Le P'tit Bal perdu (Philippe Decouflé)

- A Chairy Tale (Norman McLaren)

Para trabalhar a construção da videodança como uma câmera que dança com o bailarino e a questão do tempo e do espaço, foram apresentados, dentre outros, as seguintes obras:

- Private life of a cat, A Study In Choreography For Camera e Ritual in Transfigured Time (ambos de Maya Deren)

- Jornada ao umbigo do Mundo (Alice Ripol e Alex Cassal)

- Sensações Contrarias (Amadeu Alban, Jorge Alencar e Matheus Rocha)

- Bem-te-vi (Luisa Coser)

Para tratar do gesto, da dança e da videodança:

- Tango (Zbigniew Rybczyński)

- Café Müller e A Sagração da Primavera (de Pina Bausch)

- O baile (Ettore Scola)

- Pina (Win Wenders)

- Re:Rosas (Anne Tereza De Keersmaeker), dentre outros.

As obras foram apresentadas e o movimento escolhido pelos mediadores foi o de retomar, sempre que possível e necessário, as referências; apontando os aspectos a serem trabalhados durante o encontro. Desta forma, Montão de Coisa possui como grandes referências o projeto de Anne Tereza De Keersmaerker, Re:Rosas no que se refere à coreografia e a obra de Arthur Bispo do Rosário no trabalho de formação nos catálogos das imagens. Quanto ao seus aspectos visuais 
como a escolha das cores, podemos mapear as influências de produções recentes do videoclipe Passinho do Romano (Bonde TNT e Lucas Santos) e o filme brasileiro A batalha do passinho (2012). As cores das roupas escolhidas para a execução da coreografia evidenciam o trabalho com os emocionais da obra, fazendo referencia à cultura jovem, utilizando a cor como um aspecto emocional do vídeo. Pierotti (2016) destaca em seu texto que o cinema e o vídeo são importantes ferramentas para entender a cultura visual contemporânea, não por suas escolhas formais, mas como potencial elemento para que sejam trabalhados aspectos emocionais do filme.

A estética pós-moderna nos leva a considerar a percepção como uma experiência corporal. A ideia de ser o corpo [ele mesmo] perceptivo, une-se à ideia de que a cor não é mais uma simples sensação visual, mas uma experiência sinestésica complexa, isto é, que envolve todos os sentidos. ${ }^{27}$ (PIEROTTI, 2016 p. 4. Livre tradução)

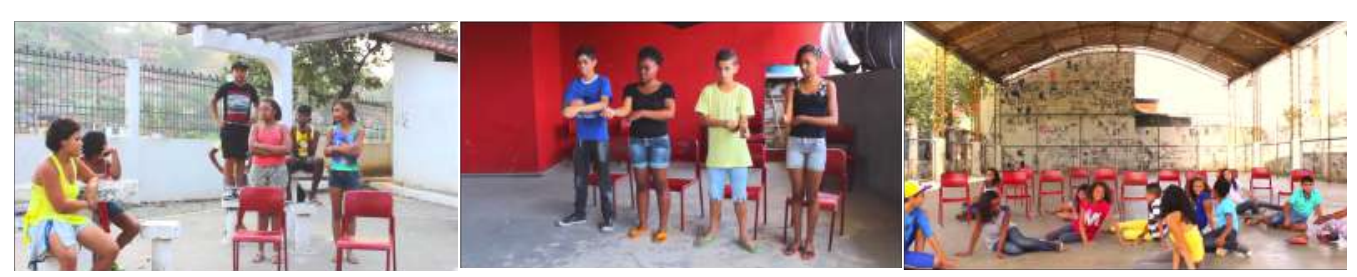

Imagem 24 - a), b) e c): Frames Montão de Coisa - estudo comparativo para observar a composição visual créditos da foto: ELC
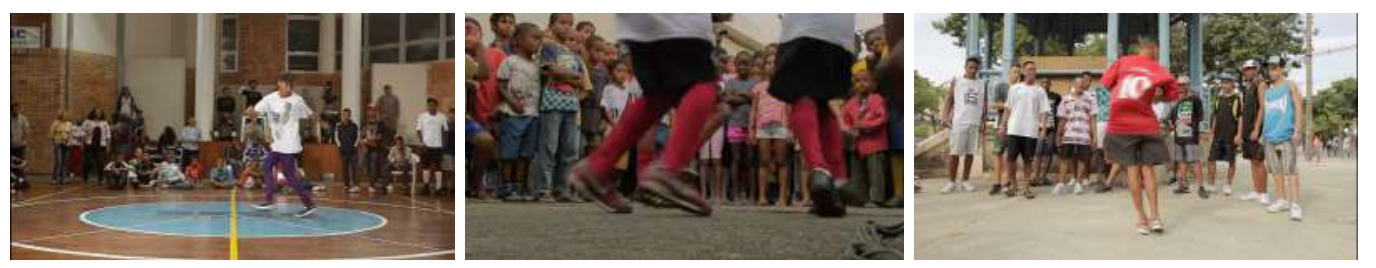

Imagem 25 - a), b) e c): Frames do filme Batalha do Passinho (Emílio Domingos, 2012), referência para composição visual

${ }^{27}$ Furthermore, postmodern aesthetics call us to consider perception as a bodily experience. The idea of it being the body that is perceiving ties in with the idea that color is no longer a mere visual sensation of the eye, but a synesthetic experience engaging all the senses. (PIEROTTI, 2016, p. 4) 

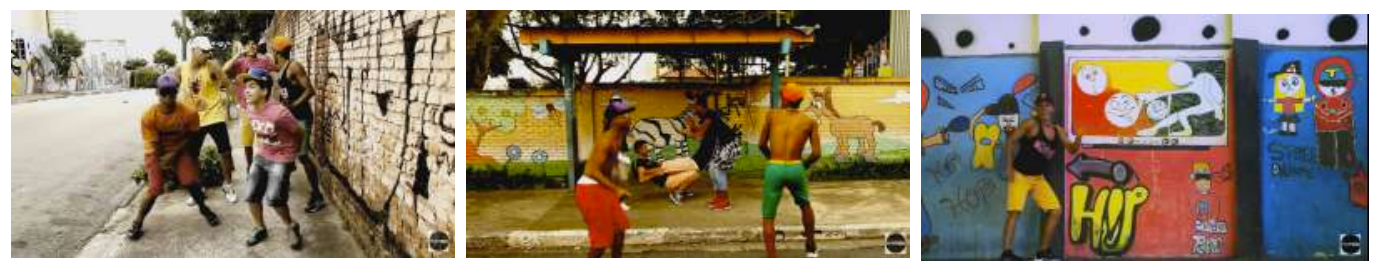

Imagem 26 - a), b) e c): Frames do videoclipe Passinho do Romano (Bonde TNT e Lucas Santos), referência para composição visual
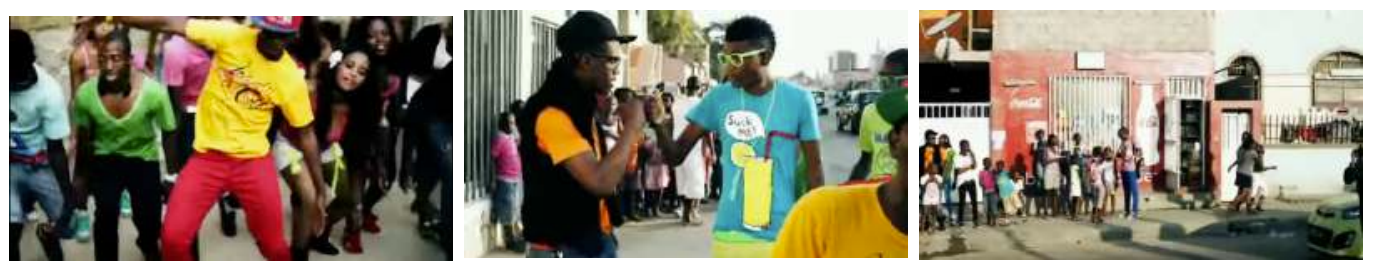

Imagem 27 - Frames do videoclipe da música Kagado, Os Kazumbis feat Cabo Snoop, referência para composição visual

Ao longo do processo foram vários os dispositivos utilizados e sobre isso podemos pensar que, embora estes não sejam únicos, no sentido de terem sidos elaborados (ou não) para esta videodança, a experiência vivenciada nas situações que os sucedem são únicas. Foi deste modo que me aproximei do conceito de experiência pensado por Larrosa $(2002 ; 2011,2014)$, considerando que esta tem sempre uma dimensão de incerteza, ou seja, não pode ser antecipada no momento da escolha dos dispositivos a serem usados, somente as ações revelam o resultado, revelam a experiência que acontece (pensando aqui a experiência como algo nos acontece).

(...) posto que não se pode antecipar o resultado, a experiência não é o caminho até um objetivo previsto, até uma meta que se conhece de antemão, mas é uma abertura para o desconhecido, para o que não se pode antecipar nem "pré-ver" nem "pré-dizer (LARROSA, 2002, p. 28).

Os aspectos técnicos e da linguagem cinematográfica, assim como as particularidades que caracterizam a videodança são trabalhados na ELC em meio a uma experiência de encontro com o outro e com o desconhecido, que toca alunos e mediadores. Larrosa (2002, p. 25) escreve que "a experiência é em primeiro lugar um encontro ou uma relação com algo que se experimenta, que se prova". Sendo assim podemos nos perguntar como esta experiência de criação vivenciada na ELC, que também pode ser lida como uma experiência de 
alteridade, se constitui como uma experiência estética? Quais relações são mobilizadas neste contexto em que a tríade "palavra, corpo e território" é usada como eixo norteador?

No capítulo 2 apresentei a ELC essencialmente como um projeto, como uma escola que funciona através de editais públicos e por meio de uma rede de colaboradores, produtores, mediadores e alunos, objetivando trabalhar $\mathrm{o}$ encorajamento estético e a produção audiovisual. Neste terceiro capítulo procurei abordar a escola pelo viés da construção da imagem, explorando seu processo de criação. Os aspectos aqui apresentados têm como objetivo auxiliar a análise do próximo capítulo acerca da metodologia da ELC, tendo em vista seus elementos constituintes e seus conceitos norteadores. Acredito que este movimento nos possibilitará perceber as relações que permeiam o fazer cinematográfico na experiência de criação da ELC e os processos subjetivos envolvidos. Por meio da leitura do processo de criação de Montão de Coisa percebemos que a experiência vivenciada pelos alunos e mediadores durante o fazer cinematográfico é marcada pela presença dos dispositivos, que servem como desafios para ações de criação. Desta forma procuro expor que, neste trabalho, a produção da ELC assume uma importância como obra, como um produto audiovisual. 


\title{
4. Palavra, corpo e território: conceitos de uma metodologia para fazer cinema
}

\begin{abstract}
Aqui na escola, tudo que a gente faz tem uma base, um tripé: a palavra, o corpo e o território. Mas esta palavra não é uma palavra escrita, não é chegar aqui, sentar e escrever. É uma outra palavra, é a maneira como a gente fala, sotaque, gíria. $\mathrm{O}$ corpo e os lugares por onde este corpo passa, o que vemos, o que ouvimos, o que trazemos de memória com a gente a partir destes lugares, por exemplo, o caminho da sua casa até aqui. (Anotações de pesquisa sobre a fala do mediador - aula 1)
\end{abstract}

Este capítulo tem como ponto central discutir a experiência processual do cinema na Escola Livre de Cinema de Nova Iguaçu, explorando sua metodologia de trabalho e a articulação entre os conceitos que a sustentam, a partir do processo de criação da videodança Montão de Coisa.

Cabe ressaltar que tanto o ano em que a empiria desta pesquisa foi produzida quanto a produção específica da ELC trabalhada aqui apresentam um momento da escola, que naquele ano completou 8 anos de existência. Além disso, foi de fundamental importância para a delimitação do escopo desta pesquisa explorar o contexto mais amplo da escola, isto é, a ELC em suas diversas dimensões: temporal, financeira, política, organizacional, institucional.

Compreendo que o viés social requer um método que contemple suas temporalidades: passado, presente e futuro. Procurei fazer esse exercício paulatinamente, ao longo de todo o texto da tese, a fim de entender como as bases da metodologia da escola se constituem, quais as formas que condicionam esse tipo de produção na contemporaneidade e quais as relações que o contexto - a cena - onde foi produzido suscita. Assim, defendo que abordar a ELC de modo a contextualizá-la de uma forma mais abrangente (a partir da sua experiência ao longo dos anos) oferece ferramentas para entender as bases de sua metodologia e também as formas que condicionam esse tipo de produção no contexto mais amplo. Neste sentido, as cartografias feitas ao longo da pesquisa e apresentadas no capítulo 2 desta tese serviram como ferramentas para viabilizar o mapeamento dos vários aspectos da escola.

A ELC assume uma metodologia de trabalho com base na tríade "palavra, corpo e território". Esses três pilares funcionam como conceitos norteadores para 
os diversos projetos desenvolvidos, como expõe um dos mediadores na epígrafe deste capítulo. A metodologia foi construída ao longo dos experimentos desenvolvidos para se trabalhar o cinema e o audiovisual na instituição, com o objetivo de promover o encorajamento estético e a produção audiovisual.

Com a sistematização do material empírico desta pesquisa, isto é, do trabalho de campo, a empiria foi se delineando e a interação com este material mostrou que o caminho para leitura e análise do que vinha se constituindo na pesquisa passava pela tríade já citada. Desta forma, aqui tomo emprestados da ELC estes conceitos e o faço num movimento de reapropriação onde eles deixam de ser vistos como conceitos e passam a ser guias dos meus caminhos de investigação, isto é, "portas de entrada" naquilo em que se transformou este textopesquisa.

Utilizei "palavra", "corpo" e "território" como categorias de análise do material empírico. Estas palavras-chave me auxiliaram na busca por significados e na leitura deste processo de criação. Perseguindo o rigor da pesquisa acadêmica, que exige o uso sistematizado e estratégico de métodos e ferramentas, mas ao mesmo tempo procurando ser cautelosa com os perigos que um possível operacionismo, como escreveu Geertz (2015, p. 4), oferece em pesquisas próximas às ciências sociais, me aproximei da etnografia para encontrar nesta prática um aporte e continuar trilhando um caminho no trabalho de investigação e interpretação. É desse modo que trabalho o material empírico: inicialmente, as transcrições das aulas, as anotações do caderno de campo, os mapas gerados pelas cartografias das teias de relações que envolvem a escola e o processo de criação descrito no capítulo 3 desta tese, bem como as fotografias e vídeos que formam uma espécie de making off da produção da videodança. Vale deixar claro que a etnografia não foi eleita por mim como "o método" de aproximação e produção das interações e interpretações empíricas. Considero ser essa uma pretensão acima das possibilidades desta pesquisa. Nesse sentido, defendo que o que ora se apresenta possui uma inspiração etnográfica. Sem a pretensão de construir uma etnografia da/na ELC, esforcei-me para apresentar algo que se aproxime de uma “descrição densa” (GEERTZ, 2015) dos processos vivenciados, como forma de interpretação das várias formas de manifestação da cultura.

Segundo a opinião dos livros-textos, praticar a etnografia é estabelecer relações, selecionar informantes, transcrever textos, 
levantar genealogias, mapear campos, manter um diário, e assim por diante. Mas não são essas coisas, as técnicas e os processos determinados, que definem o empreendimento. O que o define é o tipo de esforço intelectual que ele representa: um risco elaborado para uma 'descrição densa' (GEERTZ, 2015, p. 4).

\subsection{Para aprender fazendo}

O cinema não é somente fazer um filme, mas também a tentativa de compreender o mundo: o trabalho torna-se uma ocasião para refletir sobre algo que de certa forma vai além, supera (MARIO BRENTA em entrevista a BERTOZZI, 2003, p. 316 - tradução da pesquisadora - grifos meus) ${ }^{28}$.

A citação que abre esta seção aparece numa entrevista feita pelo pesquisador Marco Bertozzi com o cineasta italiano Mario Brenta no livro Ermanno Olmi: Il cinema, i film, la televisione, la scuola (2013), dedicado ao trabalho do cineasta italiano Ermanno Olmi. No texto, Bertozzi e Brenta conversam sobre o trabalho de Olmi como diretor e especialmente sobre o papel da escola idealizada pelo cineasta, chamada Ipotesi Cinema. A escola foi criada como um laboratório coletivo com o objetivo de desenvolver um trabalho pautado na ideia de que o cinema se aprende fazendo e que mais do que a formação de um profissional, se almeja a formação de um autor, daquele que experimenta todo processo de feitura de um filme. Neste sentido, os alunos são envolvidos numa experiência de encontro com o cinema através de projetos que os colocam em contato com as diversas etapas de produção de um filme e com o trabalho de Olmi. O meu encontro com os relatos sobre as escolas de cinema italianas aconteceu a partir das conversas que tive com o professor Marco Bertozzi, da Università Iuav di Venezia e com a professora Sandra Lischi, da Università di Pisa. Bertozzi me trouxe os relatos sobre a Escola idealizada por Olmi, da qual foi também aluno e Lischi me apresentou ao trabalho da Scuola video di documentazione sociale I Cammelli, idealizada pelo cineasta italiano Daniele

\footnotetext{
${ }^{28}$ Texto original da citação: "E poi il cinema non è solo fare film, ma anche cercare di capire il mondo: e l'opera diviene occasione per riflettere su qualcosa che in un certo modo va oltre, la supera" (BERTOZZI, 2003, p. 316).
} 
Segre e com a qual a autora tem aproximação, tendo organizado um livro a respeito.

O encontro com as escolas italianas durante o período de estágio do doutorado sanduíche e a leitura desses projetos me ajudaram a pensar e evidenciar uma de suas característica que, embora tenha origem e desenvolvimento distantes do contexto brasileiro e suas práticas, guarda proximidade com algo que ao longo do texto procuro tomar como elemento principal de minha análise: a experiência de encontro com o outro, com o mundo a partir de uma relação com o cinema.

Ermano Olmi foi um cineasta conhecido pela sua preferência por trabalhar com atores improvisados, sendo considerado como um diretor da essencialidade e da sobriedade (STAJANO, 2013, P. 306). Ipotesi Cinema nasceu de uma demanda de pessoas que se aproximavam de Olmi com o desejo de trabalhar voluntariamente em suas produções. Desde do seu nascimento a escola contou com o apoio da RAI (televisão italiana) e esta parceria foi uma das responsáveis pela viabilização financeira da escola, acrescido a isso, estão as figuras de Olmi e Paolo Valmarana. Estas características me fazem pensar a Ipotesi Cinema como um projeto que está fortemente atrelado à figura de Olmi e isso afeta tanto a relação com os alunos, que dentre outras coisas procuram a escola visando esta possibilidade de trabalho com o cineasta, quanto o fato de ter um aporte financeiro e institucional de grande relevância. Desta forma, entendo que há um fio condutor das ações da Ipotesi que evidencia sua tendência para o ensino de um cinema pautado na qualidade técnica, que percebe o aluno como alguém que está, dentre outras coisas, num processo de formação técnica e de trabalho estético.

Ainda na mesma entrevista a Bertozzi, Brenta fala do seu encontro com um outro cinema, diferente daquele comercial e pautado pelo entretenimento, este relato mescla-se com seu depoimento sobre a figura de Olmi: o encontro com um cinema que promoveu um encontro com o mundo, em um trabalho com a linguagem e o discurso do mundo, sobre o mundo. Neste sentido, um dos objetivos da escola consiste em permitir que através do fazer cinematográfico os estudantes tenham contato com a realidade, tomando este como um instrumento de conhecimento da vida. Brenta comenta que o essencial na metodologia de trabalho da Ipotesi cinema é a ideia de aprender fazendo, numa metodologia que se propõe a não fazer separação entre professores e alunos. O que determina o papel de cada um nas especializações específicas dentro do processo de criação 
cinematográfico, segundo ele é a experiência e, consequentemente, a familiaridade de cada sujeito. Na experiência desta escola a ideia de troca de conhecimento e experiência possibilita a aproximação entre os envolvidos. Da mesma forma, encontro na Scuola video di documentazione sociale I Cammelli outro exemplo de uma experiência de encontro com o cinema. No livro $A$ occhio nudo - La scuola video di documentazione sociale I Cammelli (1997), Lischi e Piazza reúnem textos sobre a experiência da escola idealizada por Segre. Dividido em 6 seções o livro apresenta textos escritos por diretores de cinema, críticos, pesquisadores, alunos e ex-alunos da escola. A ideia da escola I Cammelli se pauta na aproximação ao cinema à documentação social, através de projetos que exploram a relação com a cidade.

Lischi (1997) comenta as bases da escola: Nela o aluno aprende a se comunicar e a comunicar-se em grupo, treinando o olhar para um diálogo com o cinema que envolve ler, perceber e construir outras imagens que dialoguem com outros olhares e assim possibilitem outras leituras. Nesta experiência os alunos são encorajados a estar sozinhos diante de uma câmera, mas também a se colocar diante dela em grupo, observando o outro e aprendendo a trabalhar em conjunto. Aprendem que o cinema é algo vivo, uma máquina para pensar, um laboratório de emoções, instrumento de conhecimento e confronto.

A experiência desta escola envolve um grande número de profissionais: cineastas, críticos, roteiristas, técnicos. Todos eles atuam nas mais diversas etapas do fazer cinematográfico, num diálogo com os alunos em um processo de criação que permite que ao final de um projeto, aquele documentário (ou qualquer que seja a produção audiovisual envolvida), fruto de um trabalho de formação, seja apresentado pelos alunos como uma produção autoral. Ou seja, importa que os alunos se sintam criadores daquelas imagens. O livro escrito por Lischi apresenta uma série de artigos que tratam do trabalho da escola, alguns destes textos foram escritos por alunos, como uma espécie de relato sobre o trabalho de criação.

Estas duas experiências possuem em comum um certo compromisso com a formação técnica e o fato de estarem fortemente ligadas à figura de seus idealizadores influencia, muitas vezes, nas escolhas estéticas, políticas e a maneira como seus projetos ganham evidência. No entanto, observo que a essência do trabalho se pauta sempre por um encontro a ser promovido, seja um encontro com o outro (outros), tais como aqueles que não sendo profissionais de cinema, se 
juntam para trabalhar neste sentido - como quando nos referimos aos voluntários de Olmi, por exemplo. Pode-se também dizer isso a respeito de um encontro com a sinfonia urbana, no trabalho de videodocumentação da escola I Cammelli.

Para além das proposições acima, vale frisar que, por sua tradição nos estudos dos aspectos estéticos, os italianos me ajudaram a pensar a potência estética das obras feitas pela ELC. Durante o trabalho desenvolvido no SAGAS ${ }^{29}$, no período em que estive na UniFi, comecei a analisar o trabalho da ELC também a partir de seus aspectos estéticos, perseguindo um dos objetivos declarados pela escola: o encorajamento estético. Passou a me interessar saber como a ELC direciona seu trabalho neste sentido e como este fato atua no nascimento das imagens. Questões como “O que pauta as escolhas estéticas?” passaram a fazer parte do meu repertório de investigação, de modo que cor, cenário, movimento etc compuseram de forma definitiva o caleidoscópio do meu olhar para a empiria.

Neste sentido, aproximei-me da ideia de emancipação desenvolvida por Rancière (2004), empreendendo uma leitura da história de Joseph Jacotot (trabalhada pelo autor), cujo teor me permitiu travar uma discussão a respeito, tendo em vista que ela (a emancipação) pode ser pensada dentro da própria experiência, como a possibilidade de vivenciar algo.

E o que se vivencia nesse processo que ora chamo de emancipatório?

$\mathrm{Na}$ ELC o encontro com o cinema é dado a partir de situações e desafios apresentados ao longo dos encontros para os alunos, a partir dos quais houve possibilidade de mobilizar estratégias cognitivas, subjetivas e coletivas para cumprir uma tarefa - desde capturar 1 minuto de imagens com a câmera parada (com no Minuto Lumière) ou filmar uma cena com 3 planos diferentes -, discutila, elaborar estratégias e realizar o registro de coletâneas/coleções referentes a Austin.

Na relação dos mediadores com os alunos foi recorrente perceber situações como a descrita no seguinte diálogo, sobre a proposta de um exercício:

[mediadora] - Eu fiquei pensando em sair com vocês hoje. A minha proposta seria que a gente saísse em silêncio, sem falar... [alunos] - Risadas, rumores...

${ }^{29}$ Dipartimento di Storia, Archeologia, Geografia, Arte, Spettacolo-SAGAS, Università degli studi Firenze. 
[mediadora] - Sim, é um super desafio. [...] Eu acho que vai ser divertido uma proposta silenciosa,. A gente começa a escutar outras coisas, até olhar coisas que a gente nunca se deu conta de que tem aqui, sabe? Eu tenho feito isso durante meu período de almoço. Todas as vezes eu vou dar uma volta, do lado, em frente... Eu não conheço muito bem Austin, eu não sei onde é o limite... aonde já não é mais Austin. É bem grande, né?! (anotações da pesquisadora - aula 16 - grifos meus).

Existe um movimento na ELC, uma tentativa de colocar mediadores e alunos na condição menos vertical possível. No que se refere a um conhecimento prévio daquele lugar, do bairro de Austin, por exemplo, supõe-se que os alunos sejam moradores daquela redondeza e os mediadores mais antigos conhecedores daquele local, por já terem desenvolvido outras atividades ligadas à escola. No entanto, naquele ano duas das mediadores (das aulas de cinema, corpo e dança) não conheciam o bairro. Uma delas declarou isso em sala ao comentar que semanalmente fazia caminhadas por Austin para reconhecer o local. No mesmo dia, ela propôs uma atividade: a caminhada silenciosa. Trata-se de uma atividade em que os alunos e mediadores saíram pelas ruas de Austin, observando o cotidiano e o movimento do local. Ao longo do percurso algumas pausas propositais foram feitas, em pontos que foram escolhidos pela mediadora. Durante a pausas os alunos permaneciam em grupo e observavam. Foi comum ouvir risadas, cochichos e alguns alunos tiram fotos com os celulares.

Depois da caminhada silenciosa outra atividade foi feita de forma complementar: cada aluno teve seu corpo desenhado (por um colega) numa folha grande de papel e dentro deste desenho escreveram o que viram durante a caminhada. As palavras relatavam o que foi encontrado nas ruas de Austin, conforme demostram as fotos abaixo: 


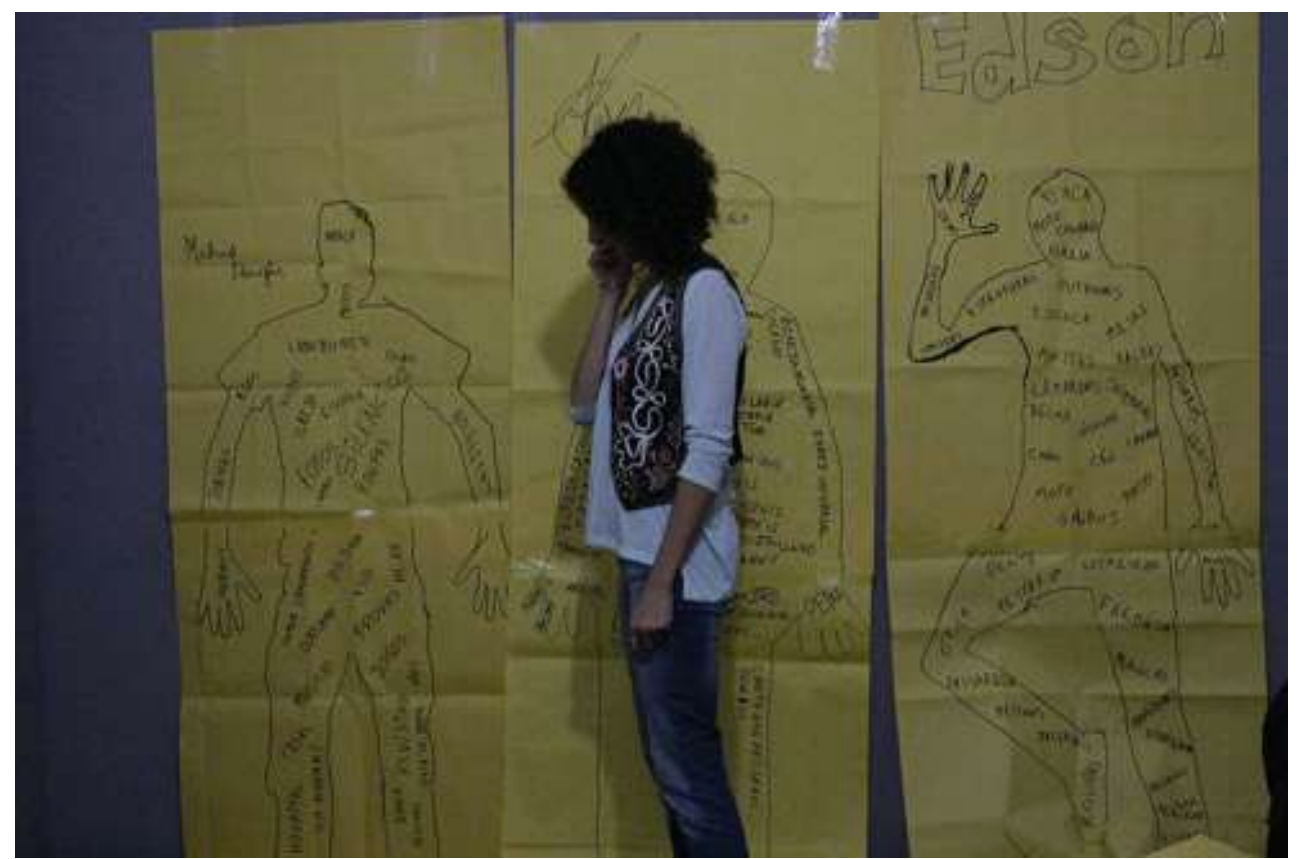

Imagem 28 - O que eu vi: desenhos feitos pelos alunos da ELC como atividade complementar à caminhada silenciosa $\bullet$ créditos: ELC

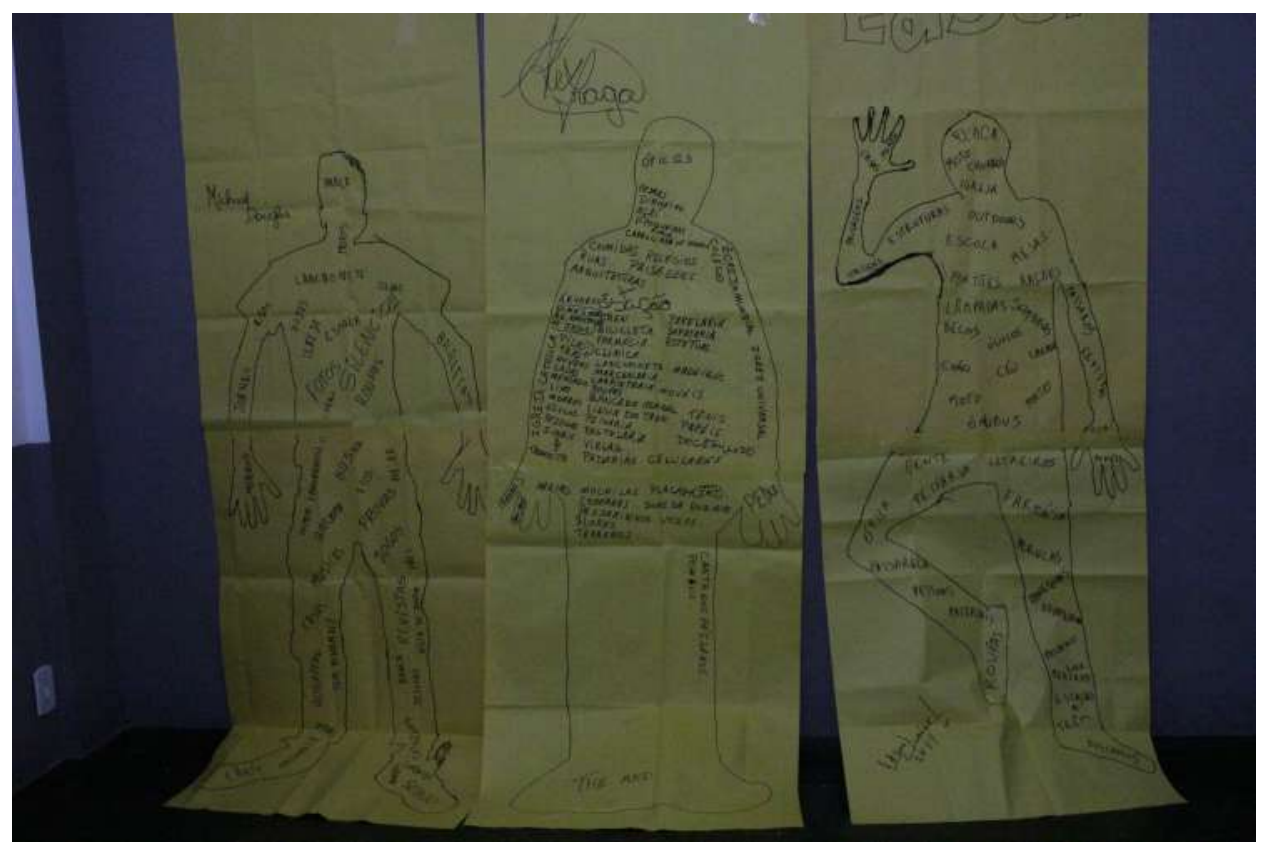

Imagem 29 - O que eu vi: desenhos feitos pelos alunos da ELC como atividade complementar à caminhada silenciosa (foto 2) • crédidos: ELC

Recorro a Rancière (2004) novamente para pensar esta ação: na história do professor Jacotot, apresentada pelo filósofo, seus alunos flamengos aprendem a língua francesa para se aproximar do livro indicado pelo mestre que não consegue se comunicar na mesma língua dos seus alunos. Sem explicações prévias, a 
distância entre os alunos e o livro foi ultrapassada pela vontade daqueles diante do desafio posto: alguns estudantes "se ensinaram a falar e a escrever em francês, sem o socorro de suas explicações" (RANCIÈRE, 2004, p. 26).

Mas a inteligência que os fizera aprender o francês em Telêmaco era a mesma que os havia feito aprender a língua materna: observando e retendo, repetindo e verificando, associando o que buscavam aprender àquilo que já conheciam, fazendo e refletindo sobre o que haviam feito (RANCIÈRE, 2004, p. 28).

Isso me faz retomar ao que discuti no capítulo 3 a respeito da vontade e da necessidade de criação inerentes ao homem, que cria para compreender e ao mesmo tempo relacionar os múltiplos eventos que ocorrem ao seu redor, numa busca de ordenações e significados. Penso que seja produtivo neste momento aproximar as noções de vontade (RANCIÈRE, 2004) e necessidade (OSTROWER, 2004).

[Na] busca de ordenações e de significados reside a profunda motivação humana de criar. Impelido, como ser consciente, a compreender a vida, o homem é impelido a formar. Ele precisa orientar-se, ordenando os fenômenos e avaliando o sentido das formas ordenadas; precisa comunicar-se com outros seres humanos, novamente através de formas ordenadas (OSTROWER, 2004, p. 9-10).

Os alunos de Jacotot haviam aprendido sem suas explicações, mas não sem um mestre, aquele que lhes indicou o livro. O fato estava posto e diante da situação, os alunos e o mestre agiram com suas capacidades e movidos pela vontade própria de vencer aquele desafio.

$\mathrm{Na}$ ELC a caminhada silenciosa pelas ruas de Austin foi proposta pela mediadora que não conhecia bem aquele território, mas que propôs um exercício para trabalhar a subjetividade e propriocepção com seus alunos. Sem igualar tais ações (as de Jacotot e as da mediadora da ELC), entendo que esta última me permite ilustrar a relação pensada a respeito do papel da necessidade e da vontade durante o processo criativo das imagens. Falo das relações estabelecidas entre alunos e mediadores durante as situações que demandavam ações de criação.

Com o objetivo de apresentar uma leitura dos processos subjetivos singulares (ou seja, dos alunos e mediadores) que permeiam o trabalho da ELC proponho que passemos a observar as ações que são mobilizadas para que a 
videodança exista. Trabalho metodologicamente com as chaves de leituras anteriormente citadas e procurando entender como a criação destas imagens revela processos emancipatórios e, da mesma forma, questiono em que circunstâncias a igualdade de inteligências se efetiva no processo.

\subsection{Entre gestos e palavras}

Esta subseção tem como objetivo pensar a metodologia da ELC utilizando a "palavra" como chave de leitura. O que aqui chamo de "entre gestos e palavras" trata da relação entre os mediadores e alunos pensada a partir da distância (RANCIÈRE, 2004) como uma característica intrínseca à metodologia da escola. Isso significa trabalhar tendo como princípio que é importante dar ao aluno a possibilidade de construir, com suas próprias ferramentas cognitivas, o conhecimento que se pretende no ato de ensinar. Sem prescindir da figura do mestre, mas antes, entendendo que ele deve ser um facilitador, promovendo mediações, criando situações de aprendizagem, mas sem com isso fornecer explicações em demasia. Nisso reside a ideia de distância: o espaço-tempo suficiente para dar ao aluno a possibilidade de desenvolver soluções por si mesmo. Esse posicionamento está pautado na convicção de que todos somos capazes de desenvolver determinados conhecimentos.

Aqui a gente abre mão da ideia de certo e errado, para nós, o mais importante é experimentar e fazer coisas juntos. Experimentar possibilidades diferentes de fazer isso ou aquilo. Este é um pouco do trabalho da escola. (Anotação sobre a fala do mediador - aula 1)

Podemos pensar que existe uma certa distância a ser mantida pelos mediadores durante suas explicações aos alunos, especialmente nos primeiros contatos destes com o cinema. Penso esta distância como um intervalo entre as explicações sobre os aspectos da linguagem cinematográfica ou a exibição de um filme e o feedback dos alunos. Esta preocupação dos mediadores se concentra em deixar que eles tenham tempo e espaço para vivenciar e pensar aquele cinema. Considero esta uma das principais características da relação estabelecida entre estes dois grupos na experiência investigada, tal aspecto além de pautar esta relação, age como elemento na construção das imagens ali criadas. Quando os 
desafios estão postos e os alunos são incentivados a resolvê-los, essa distância necessária torna-se a margem que permite a ação dos alunos de forma livre, sem o julgamento de certo ou errado. Sem a pretensão de um determinado resultado, os mediadores deixam que os alunos encontrem soluções nos seus próprios gestos de criação e tragam para esse processo suas próprias ideias.

Em meio a isso, um aspecto que me chamou atenção durante os primeiros encontros na ELC e que depois voltou a ser significativo no momento em que fui rever as anotações de aula, é que eu havia escrito poucas notas sobre as falas dos alunos. Entendo que a quantidade por si só não é determinante, mas aquele fato me pareceu indicar algo. Notei que isso foi mais recorrente durante o primeiro semestre do projeto, no decorrer do período de experimentação e das primeiras aulas sobre a linguagem cinematográfica. Era recorrente ouvir um silêncio relativamente prolongado durante o período de resposta a alguma pergunta feita pelos mediadores, algumas vezes faltavam respostas para perguntas simples como: "como foi seu fim semana?". Inicialmente imaginei que os alunos abriam mão facilmente de emitir suas opiniões, mas depois, durante o segundo semestre percebi que na verdade suas opiniões eram emitidas por gestos, risos, sinais de concordância ou discordância com a cabeça, em detrimento da expressão verbal. Neste sentido, quando os mediadores começaram a trabalhar com o dispositivos de criação, a distância mantida entre a explicação do dispositivo e o período de experimentação se fez essencial para vivenciar uma experiência com um tipo de cinema do qual eles não haviam antes se aproximado. Para nos auxiliar numa leitura possível, podemos voltar a pensar na experiência dos alunos flamengos de Jacotot, durante o período em tiveram que ler um livro numa língua diferente da sua:

Mas a inteligência que os fizera aprender o francês em Telêmaco era a mesma que os havia feito aprender a língua materna: observando e retendo, repetindo e verificando, fazendo e refletindo sobre o que haviam feito. Eles haviam procedido como não se deve proceder, como fazem as crianças, por adivinhação (RANCIÈRE, 2004, p. 28).

Desta forma, podemos nos perguntar de que forma a relação dos mediadores com o alunos condiciona a criação das imagens? A partir de uma distância, trata-se de algo como uma lacuna entre as explicações e a execução dos exercícios, é quando se permite experimentar e vivenciar as várias faces da experiência com o cinema no processo de criação: o encontro, o acaso, a intuição, 
o erro, as tentativas, os acertos, o outro. A lógica de criação passa então a se fazer da seguinte forma: conhecer, criar, pensar sobre, reiventar, expandir.

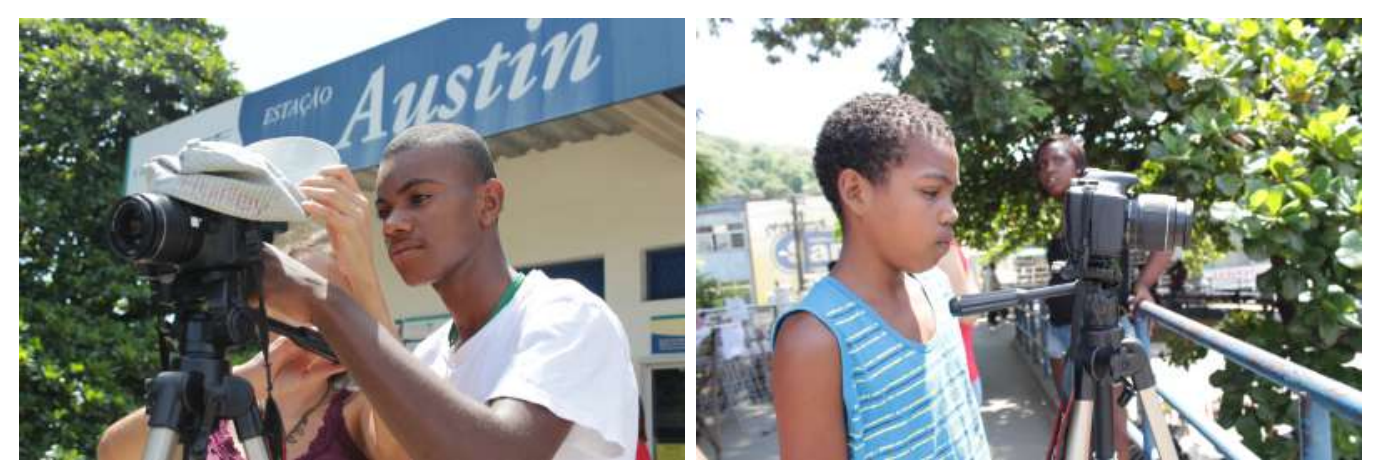

Imagem 30 - Fotos a) e b): Gravações externas para o Minuto Lumière • créditos: ELC

$\mathrm{Na}$ aula seguinte ao exercício com o dispositivo do Minuto Lumière os alunos voltaram para rua para refazer o exercício. Antes de sair da sala o mediador explica:

- A ideia é que a gente vá pra rua agora, refazer os vídeos que vocês fizeram na última quarta, agora tendo essa noção de regulagem de luz, sabendo que vocês podem tornar uma imagem mais escura ou mais clara. Tudo depende da intenção de vocês, beleza?

Ao retornar para a escola, depois da gravação, o mediador pergunta a um dos alunos que refez o exercício:

- Agora foi mais fácil ou mais difícil escolher? Você gostou mais desse resultado ou do outro?

O aluno responde:

- Gostei mais do outro! Gostei de mais do primeiro.

(Anotações sobre um diálogo entre o mediador e um aluno aula 4)

Eu não gosto de ficar olhando para as pessoas, prefiro olhar para as paisagens (Anotação sobre a fala de um aluno - aula 10).s

Percebo que na ELC a distância existente entre as explicações durante o ensino da linguagem cinematográfica e na apresentação do cinema aos alunos é pautada pelo objetivo de destacar elementos simples do fazer cinematográfico, este movimento acontece durante a experiência de criação, na rua, na sala de aula, entre as gravações ou ensaios, ou seja, no momento em que os dois grupos se juntam para criar algo a partir de um desafio que é posto pelos próprios mediadores. As explicações preliminares se propõem a serem básicas, existe um cuidado dos mediadores para que a experiência, especialmente os primeiros 
contatos com o cinema proporcione encontros: encontros com o novo, com um cinema que não se conhecia (aquele que se distancia do cinema comercial, do ingresso, da pipoca), com a rua de sempre (que pode ser diferente hoje), o encontro com a dúvida, o confronto. Para os mediadores a explicação cessa para que haja dúvidas e para que os questionamentos possam chamar atenção. E desta forma a experiência seja permeada por uma relação com a alteridade: dos alunos e, muitas vezes, dos mediadores também, uma vez que, cada novo projeto é uma nova experiência, um novo acontecimento. Cada dia de gravação é um novo desafio, um novo dispositivo a ser testado, com resultados incertos e atravessado por processos subjetivos. Cada turma tem suas singularidades: características intrínsecas, onde importa que o caráter subjetivo de cada uma delas seja evidenciado. A distância se faz necessária para que nesta relação de alteridade não falte o cinema, não falte o outro (o diferente de mim).

Rancière (2004, p. 21) tem uma passagem muito emblemática que nos ajuda a refletir sobre isso, quando o autor apresenta uma história de um livro nas mãos de um aluno, trata-se de um livro formado por vários raciocínios que tem como objetivo fazê-lo compreender uma determinada matéria. Então, o mestre toma a palavra para explicar o livro, esta ação funciona como a explicação sobre as explicações do livro. Em seguida o autor se questiona se ao invés de pagar a um mestre para explicar o livro, não seria melhor dar o livro ao filho. Desta forma Rancière esta questionando a distância que a explicação deveria praticar:

O que falta ao pai de família, o que sempre faltará ao trio que forma com a criança e o livro, é essa arte singular do explicador: a arte da distância. $O$ segredo do mestre é saber reconhecer a distância entre a matéria ensinada e o sujeito a instruir, a distância, também entre aprender e compreender. (RANCIÈRE, 2004, p. 21-22 - grifos meus)

Em um sentido inverso ao do exemplo exposto, observo o exercício feito pelos mediadores da ELC como um esforço para destacar os elementos mais simples do conhecimento de forma que isso encoraje o aluno a explorar (pela necessidade do exercício), para que assim sua vontade o faça chegar ao encontro do outro e ao gesto de criação no cinema (e com o cinema), num experiência sensível com o mundo. Este engajamento no conhecimento é um elemento que quando mobilizado trabalha no sentido de fazer surgir novas imagens, um novo filme, fazendo com que o aluno se sinta responsável pelo que está assimilando e produzindo. 


\subsection{Corpo: Gestos para uma coreografia}

\subsubsection{Primeiras tensões}

Para pensar a metodologia da ELC usando a palavra corpo como chave de leitura, tensionei aqui a relação entre "eu” (corpo) e a câmera, onde a câmera é vista como a máquina que me filma, aquela que está captando a minha imagem para posteriormente transformá-la em um filme e também como máquina que uso para filmar e que precisa ser operada. Esta relação nos mostra que na ELC a relação, a partir do corpo, passa por um processo de assimilação (empatia) com os equipamentos, com o objetivo de desconstruir um estranhamento e trabalhar uma relação de naturalização.

"Gestos para uma coreografia" aborda as relações que são mobilizadas para que a videodança exista a partir do corpo e da sua relação com a câmera.
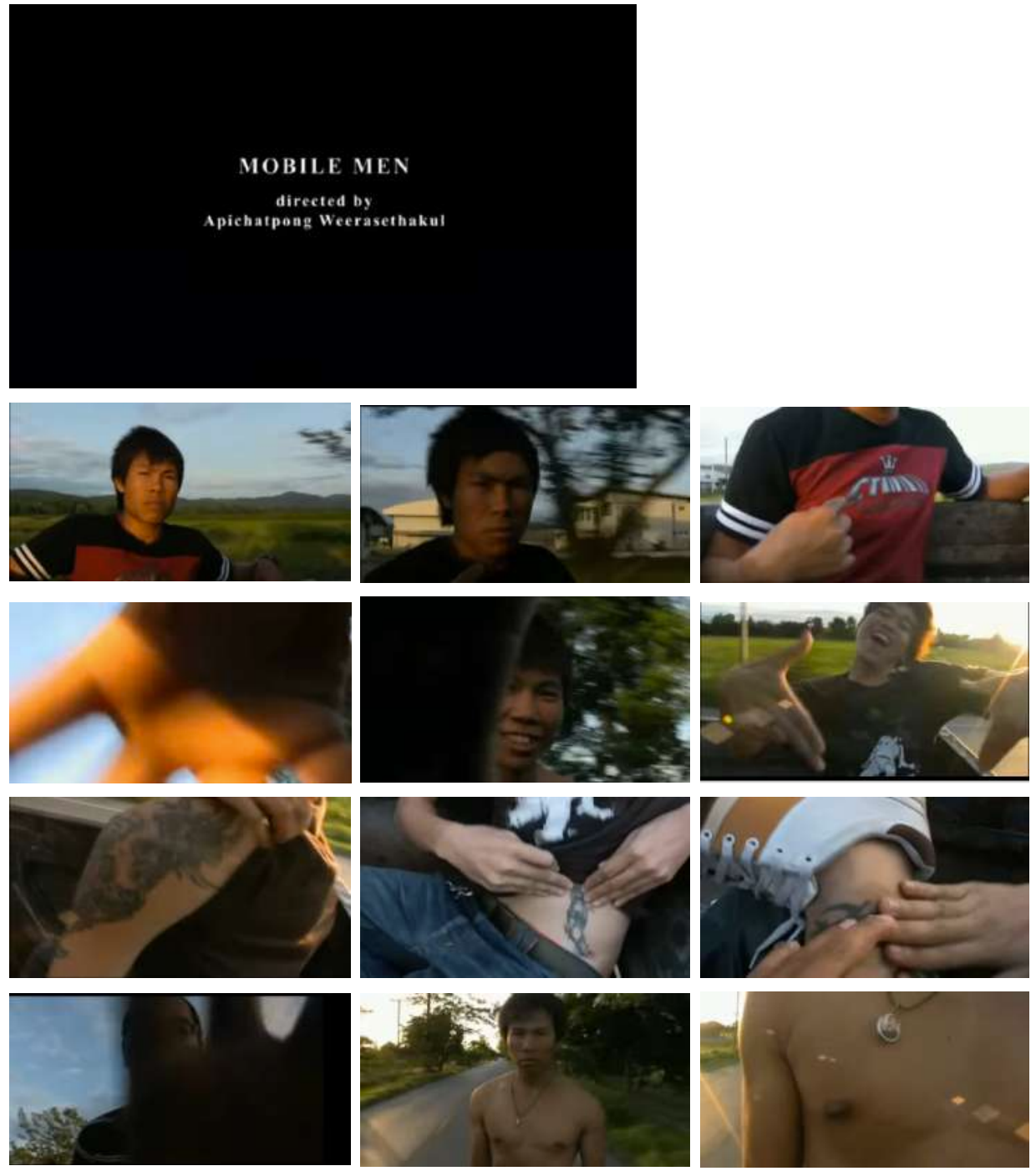

Imagem 31 - Grupo de frames: Mobile Men (Apichatpong Weerasethakul) 
Os frames apresentados na página anterior fazem parte do filme Mobile Men (2008), do diretor tailandês Apichatpong Weerasethakul. A obra aparece numa coletânea de filmes que trabalha a temática dos direitos humanos, ele foi exibido para os alunos da ELC pela mediadora responsável pelas aulas de cinema, corpo e dança, durante o tópico que tratava das abordagens da câmera-corpo e corpo-câmera. Em Mobile Men o cinema é uma ferramenta para trabalhar a percepção de si, a situação coreografada no filme celebra a juventude, a beleza e a dignidade, evidenciando gestos simples que marcam a individualidade através da interação entre os jovens com o intermédio de câmeras. Tais registros foram realizados em uma caminhonete em movimento por uma estrada, numa metáfora que procura trabalhar a liberdade para se comunicar, ver e partilhar.

Quando o filme foi apresentado aos alunos da escola, a mediadora trouxe junto alguns questionamentos:

Quem está olhando o quê? Onde está o olho? A sedução e o constrangimento: banalizar ou valorizar o gesto? Criação de padrões de beleza, de privilégios de algumas partes do corpo, principalmente do rosto. A necessidade do registro como afirmação: de quê? (Anotações de pesquisa sobre a fala da mediadora - aula 10).

Estes questionamentos colocaram os alunos de forma mais próxima à câmera, desta vez para pensar as formas de se relacionar com ela: como aqueles que filmam, como aqueles que se aproximam do outro para escolher o que vão filmar e como filmar e também como aqueles que colocam seu corpo em relação com ela, filmando ou sendo parte do que está sendo filmado. Esta abordagem aconteceu no início do primeiro semestre e serviu como base para que depois fosse trabalhada a relação da câmera com o corpo na videodança.

Durante as aulas, especialmente quando detalham a metodologia desenvolvida pela ELC, os mediadores comentam outro viés da relação com o corpo: a de que esta também é pautada por uma relação com o território, como um local por onde o corpo passa, onde ele interage e onde as ações são desenvolvidas. Existe uma preocupação em se desconstruir um estranhamento, um trabalho pautado na naturalização desses equipamentos. A câmera é apresentada aos alunos como objeto a fim de que ela faça parte do cotidiano, uma ferramenta técnica que irá auxiliá-los na construção das imagens. E o local, aquele bairro, como um local que fará parte destas imagens. 
Ao longo dos encontros este trabalho vai sendo desenvolvido paulatinamente e pode durar um ano ou meses, dependendo do projeto que estiver sendo desenvolvido. De forma geral, a ideia é fazer com que o pouco conhecimento ou a falta de conhecimento técnico não sejam impeditivos para que a experiência se desenvolva, uma vez que este tipo de produção audiovisual envolve pessoas que não têm nenhuma (ou pouca) familiaridade com a operação destes equipamentos. Na medida em que este corpo vai ser familiarizando com a câmera, mais eles se permitem experimentar as distâncias: perto e longe, filmar e ser filmado. Assim como passam a se responsabilizar pelo que será filmado, isso envolve o enfrentamento mais direto, uma proximidade com o outro, com o mundo que será filmado. A relação desenvolvida permite uma espécie de cumplicidade: do corpo em conivência com o objeto técnico e do corpo com que se coloca no mundo para afetá-lo e ser também afetado por ele.

A partir do momento em que existe uma familiaridade com esta câmera, outra necessidade surge: a de pensar os desafios criados pela presença da câmera no contato com o outro. Os alunos e mediadores enfrentam a necessidade de entender como esta câmera atua na relação com o outro, já que no cinema é com a câmera que esta aproximação acontece. Diante deste quadro, estão sempre inventando um novo lugar para câmera e novas configurações para ela, em práticas transformadoras e criativas.

Quando os alunos chegam na ELC, a princípio (e com frequência) a câmera é tida como um elemento estranho, que constrange. Esta relação da câmera com o corpo passa por diversas fases e nem sempre acontece de forma fluída com todos, existem aqueles que realmente não se sentem à vontade diante dela e permanecem assim ao longo do projeto. Paralelo a isso, é na ELC que acontece um processo de desnaturalização de certas práticas típicas de uma geração acostumada com o excesso de imagens, de informação e com a facilidade de acesso às câmeras de celular. Quando os alunos chegam na escola uma parte deles já possui vários vídeos no seus celulares, mas ao mesmo tempo há um constrangimento diante da câmera profissional. Há também algo que é muito naturalizado: este universo do excesso de imagens, onde todos podem filmar... Existe uma preocupação dos mediadores de trabalhar essa relação, a fim de proporcionar o desenvolvimento de um olhar sensível em termos de uma relação estética em meio a um cotidiano povoado por esse excesso de imagens.

Durante o processo de criação, fruto dos desafios propostos através dos dispositivos, existia sempre um papel que era dado aos alunos em paralelo: o de documentar o processo. Naquele ano os mediadores trabalharam com duas 
câmeras, uma delas disponibilizada para a excussão do exercício e uma outra usada no trabalho com o making off. Desta forma era sempre dada a opção aos alunos: todos passavam pelo processo de criação e enquanto uns estavam desenvolvendo seus exercícios, catando suas imagens, existia um outro grupo de alunos registrando todo aquele processo. Isto acontecia de forma livre e caso algum dos alunos precisasse de ajuda técnica, ela poderia ser solicitada aos mediadores. $\mathrm{O}$ intuito era sempre trabalhar a familiaridade com o equipamento, tentar desconstruir ou diminuir esta relação de estranhamento entre o corpo e o objeto técnico. O making off era o refúgio de muitos alunos, especialmente daqueles que não queriam aparecer diante da câmera.
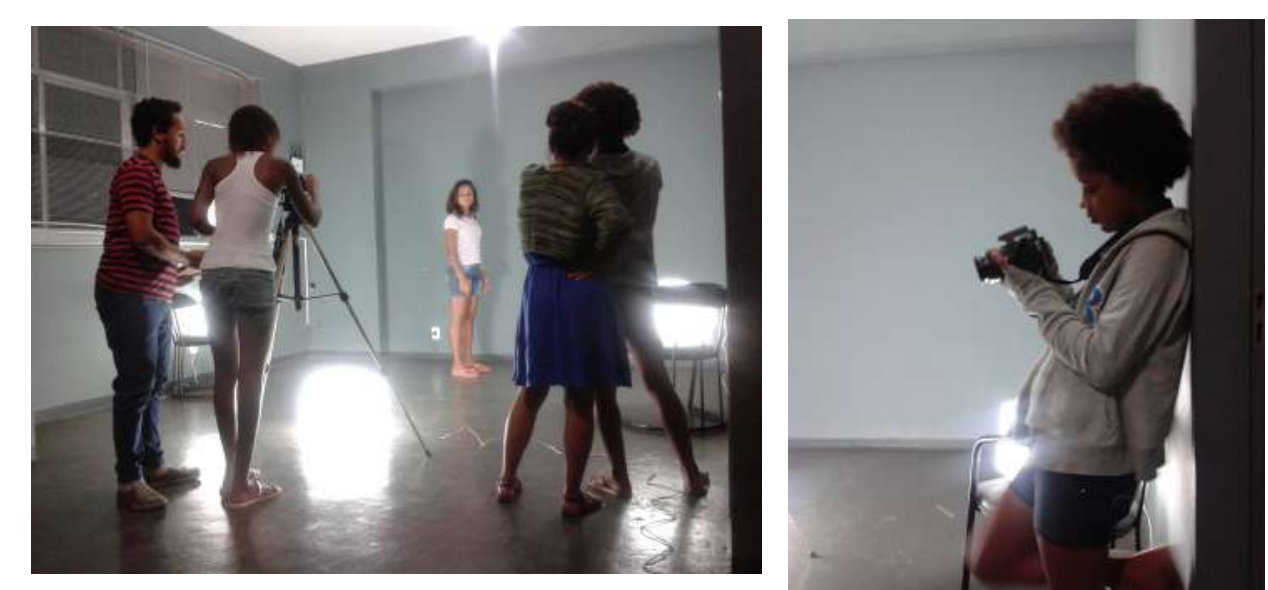

Imagem 32 - a) Gravação interna na ELC | b) detalhe: aluna fazendo making off • créditos: Theresa Medeiros
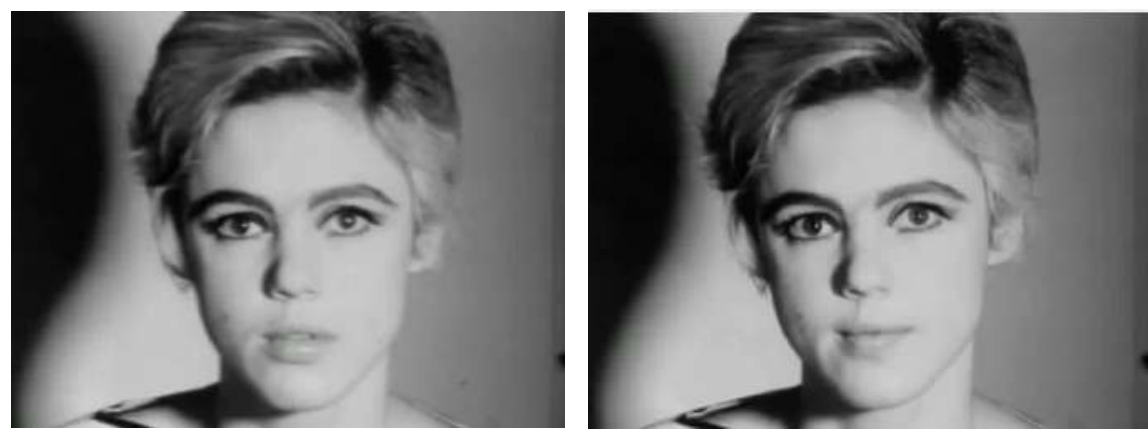

Imagem 33 - Frames de Screen Test, uma série de filmes (filmes retrato) em silêncio, gravados por Warhol. O artista fez as imagens numa câmera $16 \mathrm{~mm}$, por vários minutos ininterruptos para observar a relação com a câmera.

Para ilustrar estas situações abordadas, a câmera que constrange o corpo e o corpo interagindo com a câmera de forma aberta, alunos e mediadores trabalharam com dois vídeos, feitos em contextos diferentes: um dos vídeos da série Screen test, de Andy Warhol e o já referenciado neste texto Mobile Men, de 
Apitchatpong Weerasethakul. Ao comentar os vídeos a mediadora fez um paralelo entre o experimento feito por Warhol, pensando na reação daquelas pessoas diante da câmera que focava seus rostos durante vários minutos (imagem 34), enfatizando como a câmera pode constranger e fazendo um contraponto do experimento do artista com a ação banal de filmar aleatoriamente tudo que se deseja, fazendo menção às facilidades que a tecnologia proporciona com o celulares e as câmeras compactas. Ao mesmo tempo, trabalhou Mobile Men, numa perspectiva de proximidade e familiaridade com a câmera: "É como se eles estivessem se filmando, mas ao mesmo tempo nos mostra que não. Eles sabem que a câmera está ali e interagem com ela, não só se permitindo filmar, mas dirigindo a câmera" (anotações de pesquisa sobre a fala da pesquisadora - aula 10).

Ainda durante a aula 10, a mediadora e os alunos pensaram na ação de observar: observar as ruas, as pessoas, as ações. Lembraram do trem e do ônibus como locais propícios para esta ação. Fato interessante, em meu ponto de vista, foi que ao assumir que, no trem, ela [a mediadora] gostava de observar o que as pessoas fazem, foi interrompida por um dos alunos que disse: "eu não gosto de ficar olhando para as pessoas dentro do ônibus, prefiro ficar olhando para as paisagens". Outro aluno comentou: "prefiro usar o celular para me distrair". Trabalhar a relação daquele que está sendo filmado com a câmera talvez seja até então o maior desafio e "olhar para as pessoas", no sentido explicitado pelo aluno carrega a ação de ser observado.

Os problemas técnicos e a pouca familiaridade com câmera se tornam problemas menores quando comparado à ação de ser filmado. No entanto, em situações como estas o uso dos dispositivos, dos exercícios acabava dissipando o foco de tensão. Existia sempre tanta coisa a fazer, tantas possibilidades de se aproximar do cinema, que os alunos acabavam se envolvendo novamente.

- Todo mundo tem uma câmera dentro de si, podemos fazer um filme só com nossos olhos. (...) O cinema existe para valorizar o gesto. - Expõe a mediadora.

\section{(...)}

- Você está dizendo que os nossos olhos são como as lentes da câmera e nosso cérebro é a memória da câmera? - Pergunta o aluno.

- É, na verdade eu gostaria que vocês pensassem no corpo inteiro como um aparelho que registra sensações. - responde a mediadora (anotações de pesquisa sobre a fala da mediadora aula 10). 
Os exercícios que trabalham este viés começam com as câmeras desligadas, os alunos experimentam um trabalho manual de aproximação com o objeto, a paisagem ou uma pessoa a ser filmada. Durante o projeto que acompanhei eles trabalharam em uma atividade que consistia em desenhar e recortar 3 furos de tamanhos diferentes em uma folha de papel A4, o furo simulava a lente da câmera. Os estudantes eram postos em uma situação em que eles precisavam definir o que seria visto na imagem e o que deveria ficar de fora. Com este exercício eles trabalhavam enquadramento, percepção e a importância das escolhas. Registrando sensações eles se aproximavam de uma outra forma de criar e fazer escolhas estéticas usando o próprio corpo.

\subsubsection{Gestualidades}

As abordagens que têm o corpo como elemento principal a ser explorado seguiram ao longo dos encontros, duas delas tomaram a segunda parte do projeto de forma mais emblemática: a questão da gestualidade e a relação entre o corpo, a câmera e o movimento na videodança.

A escolha do corpo como uma das chaves de leitura para a construção da tese se deu especialmente diante da expressividade que a gestualidade teve em todo processo de criação da videodança Montão de Coisa. Muito antes de se organizar como projeto de final de curso, a videodança foi uma temática explorada naquele ano, sua linguagem e hibridações, dando sequência ao trabalho dos dois anos anteriores, pautados por uma aproximação com a arte contemporânea.

Ao longo dos encontros as mediadoras responsáveis pelas aulas de cinema, corpo e dança se debruçaram em temas caros à videodança, trabalhando a construção desta a partir de suas características, num movimento que a privilegiou enquanto linguagem híbrida entre o cinema e as artes do corpo, que não é só dança e não só videoarte, mas a comunhão dessas duas linguagens.

O trabalho com o gesto está na essência da construção da coreografia de Montão de Coisa, e estudá-lo aqui se faz num movimento que procura estabelecer uma ponte entre a relação do corpo com o mundo, que envolve percepção, movimento, aprendizado e pré-disposições emocionais. 
Para Greiner (2013) “a partir do reconhecimento de que a cultura se constrói no trânsito entre o individual e o coletivo, entre o dentro e o fora do corpo, operando o tempo inteiro num continuum entre emoção, razão [e] ação corpórea (...) (versão kindle, posição 1463).

Discorrendo sobre o gesto, Greiner propõe que estes podem ser entendidos como:

Gestos são uma prática simbólica, incorporada cinestesicamente, conhecida por quem faz, visualmente conhecida pelos observadores e derivada de um mundo, onde está também embebida naquilo que as mãos operam (GREINER, 2013, versão kindle, posição 1411).

Baseado na noção trabalhada por Greiner (2013) podemos concluir que o gesto é uma ação simbólica que carrega um significado de acordo com o contexto (cultural etc), é uma ação corporal, conhecida por quem faz e também por quem observa. Neste sentido, "a relação entre alguém que faz uma ação e o outro que a observa, ajuda a entender como as coisas podem ser transformadas em ação simbólica" (GREINER, 2013, versão kindle 1401).

Esta perspectiva considera a nossa interação com objetos e situações, o uso que fazemos com nossas mãos, por exemplo. Nos aproximamos e nos comunicamos com outros quando representamos o mundo gestualmente e os convidamos a entender gestos de acordo com contextos que se constroem durante a relação. Segundo a autora, “a comunicação gestual é portanto mediada pelo conhecimento experienciado sobre o mundo material (GREINER, 2013, versão kindle 1401).

Quando se criam situações que permitem ao aluno comparar seu corpo com a câmera, este aparato técnico toma uma dimensão simbólica para ele. Os exercícios que tratam desse aspecto são pautados na percepção, na forma como olhamos, como observamos e na passagem contínua do micro ao macro e vice-versa. Instigados por isto, os alunos receberam o desafio de fazer um diário de caminhada, tratava-se de anotações sobre o que observaram nos caminhos que percorreram ao longo do dia. Na aula seguinte um dos alunos apresentou um vídeo da sua caminhada da escola até em casa. No vídeo, percebemos pausas e observações sobre os elementos encontrados. A mediadora perguntou se ele sempre percebeu tudo aquilo., ao que o aluno respondeu negativamente.

$\mathrm{O}$ vídeo do aluno serviu para ilustrar a aula que trabalhou o tema "do percurso à narrativa", uma aula que abordou essencialmente a metáfora como exercício 
poético, passando por temas como o olhar subjetivo e a "câmera que dança". O exercício trabalhado com este tema foi a caminhada silenciosa, sobre a qual trago agora minhas anotações:

Pedras, açaí, pipoqueiras, carroça de frango, comidas, ruas, paisagens, arquiteturas, igreja mundial, igreja universal, colégio, árvores, nome dos 12 apóstolos de Jesus, trem, bicicleta, farmácia, lanchonete, madeiras, casa, mercado, lixo, banca de jornal, tênis, doces, lojas, celulares, sinais de trânsito, igreja católica, religião, areia, mochila, placas, buzinas, sons, codornas, pombos, pássaros, peixe, estação.

- ESTAÇÃO você colocou bem no centro do corpo e com letra diferente, né?! - pergunta a mediadora.

- É porque tem bastante coisa sobre ela, então eu centralizei ela. É porque a estação é o coração de Austin. - responde o aluno.

- Você dizer que a estação é o coração de Austin é uma metáfora. Tudo isso pode ser uma metáfora. Entenderam? Tudo isso aqui pode ser uma metáfora do Alex ou, da vida do Alex em Austin. - argumenta a mediadora.

- A sua vida é mais em Comendador Soares ou em Austin?

- Eu acho que em Austin.

- Que relação você tem? Você sente que pertence mais a Austin do que a Comendador Soares?

- Minha avó mora aqui, minha mãe, meu pai...

- E você não mora com eles?

- Não, moro com minha tia.

(anotações de pesquisa sobre diálogo entre mediadora e aluno aula 18).

Durante o exercício de escrita nos desenhos dos corpos os alunos listaram os locais percorridos e ao mesmo tempo fizeram metáforas a partir da relação de alguns locais de Austin com as partes do corpo. Durante a leitura das palavras a mediadora chamou atenção para isso: "Vamos prestar atenção, vamos passar por todos os corpos. Ele sabe porque colocou a "ótica" nos olhos, a estação no centro. São decisões conscientes" (anotações de pesquisa sobre a fala da mediadora aula 18 - grifo meu). Posteriormente este exercício de propriocepção, de observar o bairro, serviu de base para a composição dos gestos que estruturam a coreografia, uma vez que objetivou também despertar os alunos para a singularidade de cada um percebendo e agindo no mundo. A mediadora enfatizou o sentido de territorializar a vivência: os códigos implícitos e a necessidade de flexibilizar os signos e os significados, para aprofundar a experiência de cada um, 
atentando e alertando para os discursos, corporais e verbais. Com isso, terminou o encontro com uma pergunta: $\mathrm{O}$ que queremos falar e como?

Podemos então pensar este contexto (refiro-me território) como "contextosensitivo" (KATZ; GREINER, 2013, versão kindle, posição 1887), como aquele que é parte do processo de criação. As autoras trazem esta noção do corpo para pensar a relação do ambiente como um ambiente contextual, em que o 'onde' deixa de ser apenas um lugar de apresentação, de atuação e se transforma em um parceiro ativo das produções.

As relações entre o corpo e o ambiente se dão por processos coevolutivos que produzem uma rede de pré-disposições perceptuais, motoras, de aprendizado e emocionais. Embora corpo e ambiente estejam envolvidos em fluxos permanentes de informação, há uma taxa de preservação que garante a unidade e a sobrevivência dos organismos e de cada ser vivo em meio à transformação constante que caracteriza os sistemas vivos. Mas o que importa ressaltar é a implicação do corpo no ambiente, que cancela a possibilidade de entendimento do mundo como um objeto aguardando um observador (KATZ; GREINER, 2013, versão kindle, posição 1898 - grifo meu).

Neste sentido, o corpo, na experiência da ELC, pode ser pensado a partir da noção de corpomídia trazida por Katz e Greiner (2013), que traz a perspectiva deste no ambiente como um corpo em estado do sempre-presente, o que impede pensar este como um corpo recipiente. Para entender isso podemos partir das seguintes ideias:

[1] O corpo não é o lugar onde as informações que vêm do mundo são processadas para serem depois devolvidas ao mundo. [2] O corpo não é um meio por onde a informação simplesmente passa, pois toda informação que chega entra em negociação com as que já estão. [3] O corpo é o resultado desse cruzamento, e não um lugar onde as informações são apenas abrigadas (KATZ; GREINER, 2013, versão kindle, posição 1909).

A noção de corpomídia lida com o entendimento do corpo como "mídia de si mesmo" (KATZ; GREINER, 2013) e não com a ideia de mídia pensada como veículo de transmissão. Esta construção compreende um entendimento de como nos relacionamentos com o mundo, como pensamos, agimos, experimentamos, criamos ou nos comunicamos e sobretudo, como fazemos isso no nosso cotidiano. Tudo isso vira matéria metafórica. 
A gente queria levar a imagem para uma outra forma geométrica. Escolhemos o círculo juntamente pela ideia de circular pelo território. Circulando. Além disso, no outro vídeo que vimos, a gente queria demonstrar, de alguma maneira, a relação que o nosso corpo tem com o espaço que a gente ocupa. Sem uma pegada ambientalista.

Como o nosso corpo parece com determinados aspectos do planeta. Por exemplo: a mão, se você olhar bem de perto ela tem muita semelhança com o solo seco, que já teve água em algum momento e depois teve a seca, ficou rachado. A impressão digital etc (anotações sobre a fala do mediador - aula 1 - grifos meus).

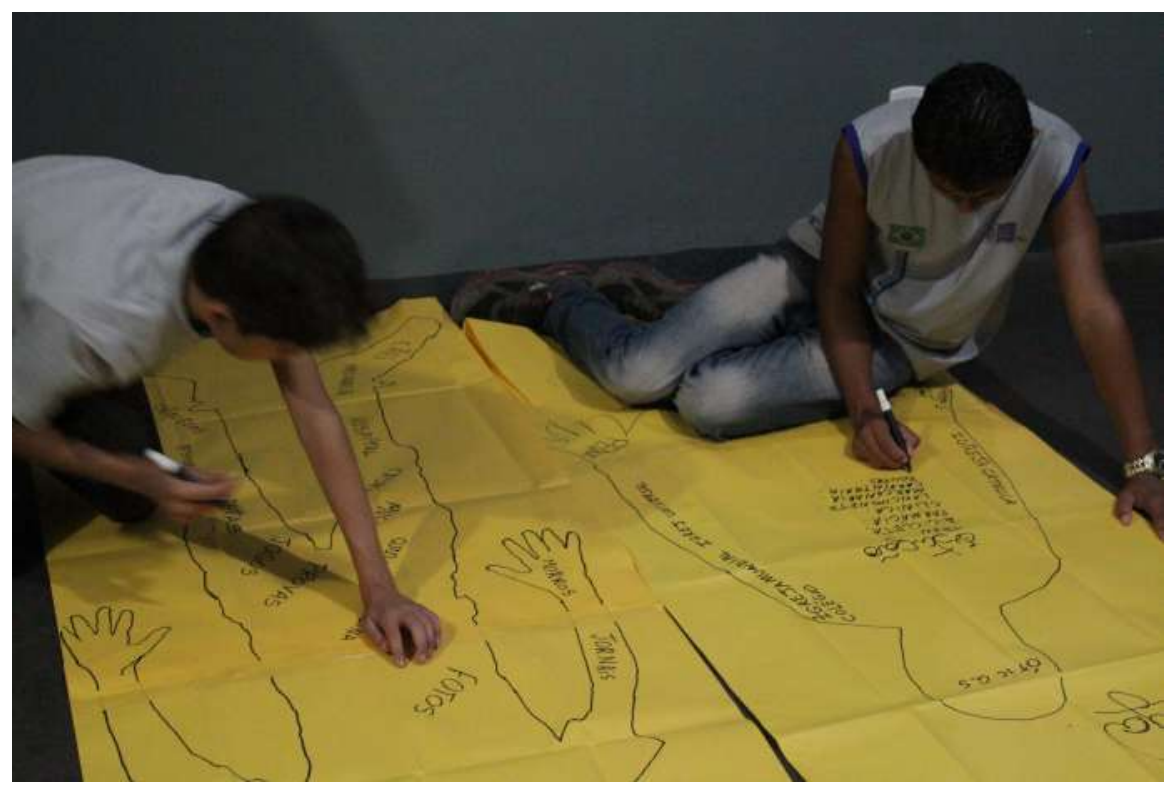

Imagem 34 - Por onde passei: descrevendo a caminhada pelas ruas de Austin - créditos: ELC

A percepção do mundo e do outro ao seu redor foi o caminho para que os alunos construíssem a noção de percepção dos gestos e sua manipulação. Em outro exercício, na sala de aula, eles se organizaram em um grande círculo, uma roda de gestos onde cada um deveria fazer um gesto a ser repetido por todos em seguida. A ideia deste exercício era fazer com que cada aluno se conscientizasse da percepção e da qualidade do movimento do outro, da intensidade, da duração e demonstrasse isso ao repetir a ação feita pelo colega. A roda de gestos proporcionou aos participantes que se trabalhasse também a acumulação de gestos, onde cada pessoa deveria repetir o primeiro gesto e adicionar outro, a terceira pessoa repetia os dois primeiros gestos e adicionava outro e assim por diante. Novamente aqui é a observação de si e do outro que transforma a ação simbólica. 
Durante o período em que o gesto se tornou o tema central nos encontros da ELC as aulas de linguagem se aproximaram mais da videoarte e da videodança, as noções de planos e movimento de câmera foram tomando dimensões mais próximas àquelas do trabalho com o vídeo, das formas híbridas. A experiência com a criação das imagens foi se deslocando do sentido rotineiramente conhecido com o cinema comercial e as narrativas lineares. Usando o corpo como norteador neste exercício de aproximação, os alunos e mediadores começaram a treinar o deslocamento de uma câmera que dança, do movimento que persegue a dança. No que se refere aos gestos, discutiu-se o limite/abertura dos signos gestuais, sobre os deslocamentos dos sentidos na recepção do gesto do outro, procurando perceber como a ação do outro me afeta. Neste ponto o trabalho teve como referência principal os trabalhos de Maya Deren e Pina Bausch.
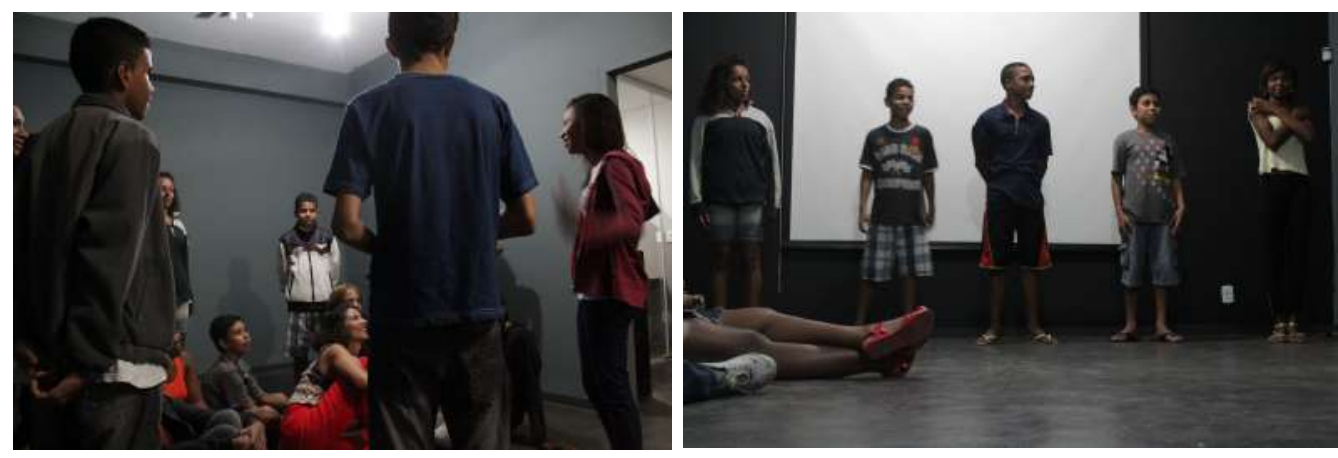

Imagem 35 - Alunos durante exercício de percepção do gesto do outro • créditos: ELC

O estudo dos vídeos de Maya Deren, especialmente com o vídeo Ritual in Transfigured Time, deu ao projeto a noção prática de como o corpo e a câmera aparecem de forma integrada na videodança e como as noções de espaço e tempo se reconfiguram em um cinema de dimensões sensoriais e poéticas.

Gradativamente a gestualidade aparece no projeto como um suporte estético. O trabalho com a relação gesto-tema-problema insere o gesto num contexto dramatúrgico que explora seu efeito, duração, ritmo, transição e intenção. Isto foi apresentado aos alunos através de uma pergunta feita pela mediadora: Como realizar um gesto diante do assunto que queremos tratar? Neste ponto, o encontro com os filmes da bailarina Pina Bausch deram a noção de como a gestualidade pode ser trabalhada diante de uma problemática. O encontro com a obra de Pina 
Bausch foi feito através das fotos de alguns catálogos dos seus espetáculos e duas de suas coreografias, A Sagração da primavera e Café Müller. O exercício prático deste encontro foi organizado da seguinte forma: cada aluno escolheu um gesto com base em uma das imagens dos catálogos; em uma roda os gestos foram realizados um após o outro, enquanto os mediadores gravavam a dinâmica das apresentações. No final do encontro os alunos assistiram aos vídeos com objetivo de observar as dinâmicas da apresentação.

O trabalho com o corpo abordando a relação com a câmera e a gestualidade foi a base para uma nova dinâmica nos exercícios com o território, sensibilizando os alunos para uma nova forma de observar as imagens cotidianas e explorar o bairro como cenário e como fonte de referência para a construção da coreografia, numa busca por elementos que serviram de inspiração e um movimento que paulatinamente trabalhou o encorajamento estético. Quanto mais envolvidos com o processo de criação os alunos ficaram, mais se engajavam no projeto. As noções que norteiam a metodologia da ELC trabalham de forma complementar, interligadas. Palavra, corpo e território.
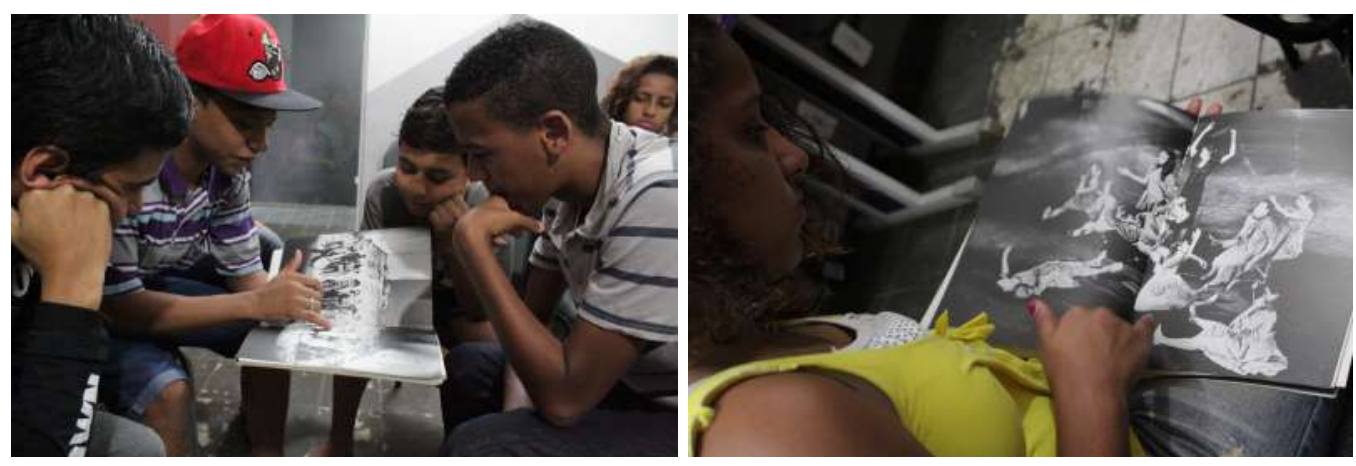

Imagem 36 - Catálogos e referências: estudo sobre o trabalho da coreógrafa Pina Bausch

\subsection{Território: a caminhada como experiência estética}

O trabalho com o território como um dos norteadores da metodologia é o mais consolidado quando observamos as três palavras chave que conduzem o trabalho da ELC: palavra, corpo e território. Enquanto a palavra aparece como forma de expressão, enfatizando um campo simbólico, valorizando as singularidades linguísticas e gestuais dos alunos e mediadores, o corpo surge com 
suas tensões (aquele que opera a câmera e aquele que é filmado por ela) e a gestualidade extraída, trazida e trabalhada pelos alunos e mediadores. Por fim, é com e no território que essas ações se efetivam. Diante disso, entendo que o território é uma peça fundamental para entender como as ações de criação acontecem na ELC.

Para desenvolver esta seção parti de duas questões que julgo fundamentais para entender como a metodologia se articula com as ações da própria escola: a primeira delas consiste em entender como a ELC vê o território e a segunda diz respeito a uma aposta, feita nesta pesquisa, na leitura do território como um espaço.

\subsubsection{Para pensar espaço e lugar}

Encontrar a ideia de território foi um pouco o momento 'achamos', 'eureca'. Pensamos: é por aqui que vão aparecer novas histórias e discursos, a gente vai ser meio artista, meio fazedor, encontrando um lugar que era um lugar vazio. Nós fomos os primeiros a dizer que, disparando uma ação artística e estética no território, vem um novo imaginário, uma nova subjetividade. Isso é meio arte, meio ação social, e com isso a gente ficou livre para criar algo novo e as pessoas aceitarem (Fala de Marcus Faustini, ELC - publicação de $10 \operatorname{anos}^{30}$, p. 42 - grifos meus).

Para pensar aqui a noção de território tensiono a relação deste com o espaço, no sentido de um lugar onde as ações acontecem e se desenvolvem, ou seja, é permeado por movimentos. Nele os alunos e mediadores da ELC criam a partir dos desafios de cada projeto ou cada etapa em desenvolvimento. O bairro onde a sede da escola se encontra serve então de referência e suas imediações são exploradas na busca por uma experiência estética. Percebo que este movimento teve início quando a sede da escola ainda era no Bairro de Miguel Couto, também em Nova Iguaçu. Com as ações desenvolvidas em Austin, uma nova fase da relação da escola com o território se estabelece.

\footnotetext{
${ }^{30}$ A ELC - publicação de 10 anos foi intitulada "Do documentário à videoarte, as principais cenas de uma história ainda em curso - 10 anos da Escola de Cinema de Nova Iguaçu", trata-se de um conjunto de entrevistas com o idealizador da ELC, Marcus Faustini, com a coordenadora de produção Luana Pinheiro e Coordenador metodológico, Diego Bion. A publicação foi feita em 2015, coincidentemente o último ano de funcionamento da escola.
} 
Originalmente estivemos em Miguel Couto, tivemos várias experiências ligadas àquele lugar. Aqui em Austin a gente tem tentado explorar este espaço. É um espaço novo pra gente também, digo, eu e algumas pessoas da escola (Anotações sobre a fala do mediador - aula 1).

Na ELC o trabalho mais direcionado com o território começou em 2006, quando a escola desenvolveu um projeto chamado Coletores de Imagens. As ações deste projeto levavam alunos e mediadores a andarem pelo bairro, numa espécie de caravana, os grupos se dividiam e saíam de casa em casa para colher imagens e conversar com os moradores. Dessa forma reuniam material e depoimentos que deram origem a um filme. Pelas ruas havia uma movimentação atípica, algumas pessoas tocando maracatu em frente a um carro de som. Os moradores saíam de suas casa para ver o que estava acontecendo, ficavam curiosos. Esta ação levava a escola para as ruas numa experiência com aquele espaço e com os moradores, catando histórias e subjetividades. Sobre este projeto, Luana Pinheiro - que em 2006, quando o projeto foi criado, era aluna da escola e em 2014 estava na ELC como coordenadora de produção da escola - diz: "acho que é pegar as representações daquele lugar, na essência, ir lá, bater na porta sem a pessoa esperar" (ELC - catálogo de 10 anos, 2015, p. 9).

O exercício de catação descrito foi usado também como um dispositivo estratégico para mapear espaços a partir do que é ordinário, do dia a dia, coisas que geralmente não chamam atenção de quem passa por ali cotidianamente.

O [projeto] coletores talvez seja o grande apontamento da metodologia da escola e do que a gente foi fazendo depois. Isso da catação, de ir para o território e não ficar dentro do prédio da Escola só pensando (Fala de Luana Pinheiro, ELC - catálogo de 10 anos, 2015, p. 9).

Neste sentido, o espaço urbano é pensado como um cenário rico para o trabalho de criação da ELC. A cidade torna-se um campo de investigação e questionamento da demarcação e da organização urbana. Cenário de uma experiência estética, na busca por cores, texturas, enquadramentos, gestos.

Tem uma coisa na Baixada, nas periferias [do Rio de Janeiro] como um todo, de que as pessoas estão acostumadas a pensar que ali não tem nada.

(...) 
Todo trabalho da Escola passa por mostrar que não, que ali há coisas, sim [...]. E as pessoas começam a perceber que tem um monte de coisa bacana que se pode falar sobre o lugar, sem apenas querer que ele seja um outra coisa (Fala de Luana Pinheiro, ELC - catálogo de 10 anos, 2015, p. 10).

A relação com o território e o movimento de ir para a rua, de sair das salas da escola, o "sair da zona de conforto", como expressou certa vez um dos mediadores, é intencional para a ELC. Trata-se de encontrar o outro, sem um roteiro prévio ou pistas do que vai encontrar. É justamente neste momento que eles aproveitam para conectar o que foi aprendido em sala, com as exibições dos vídeos e referências da videoarte, com as explicações sobre a linguagem e o fundamento sobre a relação do cinema com o corpo e dança com o território.

Se a gente está falando de videoarte com os alunos, a gente fala de como o cara que tem a banquinha de DVDs dele na passarela da estação de trem, como a estética dele pode ser pensada como algo que esteja próximo dessa linguagem que estamos trabalhando, num primeiro momento muito distante da cultura popular. Essa ida ao território em busca de referências e elementos é um esforço em todas as nossas metodologias, de estar sempre muito conectado com aquela realidade, com a vivência dos alunos, com as referências e repertórios que eles já trazem. (Fala de Diego Bion, ELC - catálogo de 10 anos, p. 10)

Quando a escola muda sua sede de bairro, este outro lugar também é tomado como um espaço de experimentação para os alunos, os dispositivos disparam ações que tocam diretamente a relação dos alunos e mediadores como aquele local. Tomando o projeto desenvolvido em 2014 como ponto de observação, no primeiro semestre percebemos um trabalho que se desenvolve na observação e no exercício de perceber o que é corriqueiro com outros olhos.

As situações trazidas pelos dispositivos e seu caráter de imprevisibilidade, no sentido de não dar pistas sobre o que se vai encontrar naquele dia, sobre o outro, sobre o mundo que acontece ali fora, é desta forma que se dá o encontro com "a astúcia urbana" (JACQUES, 2012, p. 15), com os modos de viver daquele espaço. Pensando em Austin, basta caminhar pela passarela para perceber a enorme diversidade: vendedores, trabalhadores apressados, estudantes conversando, cachorros dormindo, pessoas correndo para pegar o trem que está chegando na estação. 

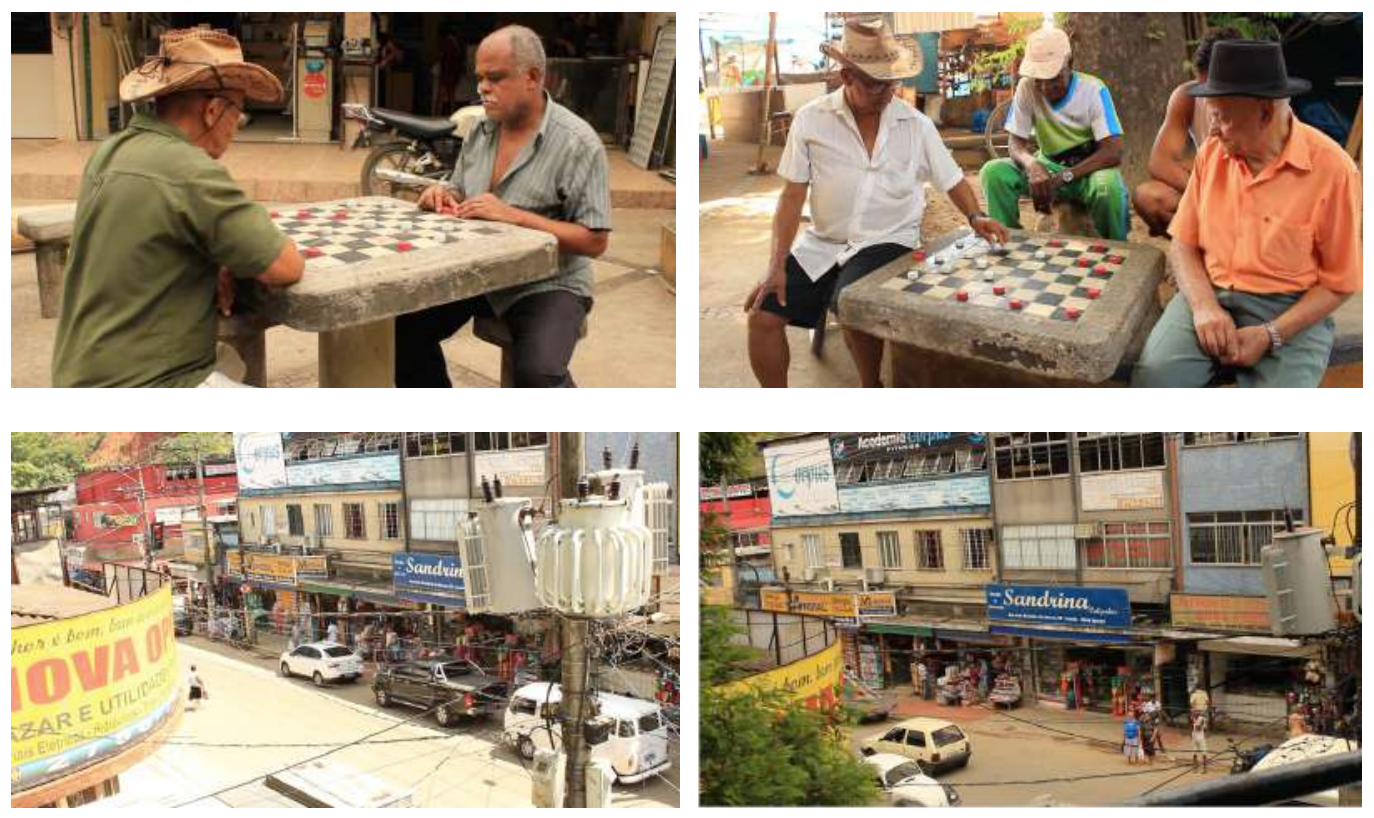

Imagem 37 - Frames do Minuto Lumière, Turma C - a) e c) primeira gravação e b) e d) regravação -

As imagens acima foram feitas durante os exercícios com o Minuto Lumière. Lembro-me quando a mediadora trouxe a proposta de refazer o trabalho, durante a aula 4: um dos alunos havia feito a gravação com os dois senhores que ficam na praça de Austin (frame a), próximo à passarela, jogando damas e, ao receber a proposta da mediadora, o que veio à tona imediatamente foi: "Mas será que eles estarão lá hoje? E se não nos deixarem filmar? Aquele senhor ficou tímido" (anotações sobre a fala dos alunos - aula 4). Eles não tinham ideia se o senhores estariam lá novamente, muito menos se aceitariam uma nova filmagem.

Grande parte das situações vividas pela ELC em conexão com o território, nesta experiência com o cinema, parte dos desafios que os dispositivos impõem, e diante desta forma de se relacionar com o território me aproximo das colocações desenvolvidas por Michel De Certeau, no livro $A$ invenção do cotidiano: artes de fazer (1998) ao pensar uma distinção entre lugar e espaço. Para este autor, lugar é um território delimitado, "uma configuração instantânea de posições" (DE CERTEAU, 1998, p. 201). Já o espaço aparece diante das ações, dinâmicas e práticas criadas sobre os lugares, neste sentido, para ele o "espaço é um lugar praticado" (idem p. 202). 
Sendo assim, quando pensamos em Austin como um dos bairros de Nova Iguaçu, ou como aquele que com o menor Índice de Desenvolvimento Humano ${ }^{31}$ da cidade ou como uma localidade que não possui sala de cinema, estamos pensando no lugar. Ao pensarmos na rua transformada pelos moradores, nas práticas dos alunos e mediadores ou nas ações e na movimentação (movimento + ação), estamos assim ponderando a transformação deste território em espaço. Trata-se de pensar o espaço como aquele que é produzido pela prática do lugar. É o espaço onde os alunos vão filmar, onde se juntam para fazer as batalhas do passinho $^{32}$, lá gravam seus vídeos com o celular, se encontram, organizam cineclube etc.

\subsubsection{Caminhos para percorrer: deslocamento e criação}

O uso do território como chave de leitura me apresentou um cenário em que as ações de criação da imagem cinematográfica pautam as relações estabelecidas com o território. Desta forma, a intenção desta subseção é pensar a caminhada como uma experiência estética, no movimento que parte da ideia desta [caminhada] como um deslocamento pelo espaço. Estes deslocamentos pelo território são mobilizados pelos desafios propostos pelos dispositivos, fazendo com que o ato de criação se desenvolva ali, no espaço urbano, o que nos leva a pensar as ruas daquele bairro como espaços urbanos praticados.

Estas caminhadas aparecem durante o projeto como objetivo principal em alguns dispositivos (a exemplo da caminhada silenciosa já descrita) e também como parte de outros. Desta forma, as situações que surgem durante a experiência de criação com o espaço já não pertencem somente aos alunos, nem somente aos mediadores e nem unicamente àquele lugar: em meio ao processo de criação, os percursos de espaço revelam um encontro permeado por tensões.

\footnotetext{
${ }^{31}$ Índice estabelecido pelo Instituto Brasileiro de Geografia e Estatística (IBGE). In: IBGE cidades http://www.cidades.ibge.gov.br/xtras/perfil.php?lang= EN\&codmun=330350\&search=\|infogr\%E 1 ficos:-informa\%E7\%F5es-completas - ultimo acesso em: 07 de fevereiro de 2017.

32 Batalhas do passinho são competições de coreografias feitas com passos de funk, estas competições reúnem performances de meninos e meninas e podem acontecer em vários locais da cidade. Nos encontros da ELC é comum ver os alunos ensaiando e compartilhando novos passos. In: http://mapadecultura.rj.gov.br/manchete/batalhas-do-passinho, acesso em 05 de fevereiro de 2017.
} 
Pensemos no exercício do Minuto Lumière: os alunos chegam na rua num dia comum, não há programação alguma até aquele momento ou algum evento especial no bairro. A rua segue seu fluxo cotidiano quando, a partir daquele momento, o local é escolhido: vamos filmar uma das barracas de verduras que ficam na passarela. Os alunos caminham até a passarela, conversam com o dono da barraca que impõe uma condição: "filmem o meu couve-flor roxo, ele é diferente". Negociação feita, a câmera é posicionada e a imagem é captada. As imagens começam a aparecer no pequeno visor da câmera e o vendedor de verduras se sente orgulhoso. Temos um evento, um encontro naquele espaço.

Sair da escola para filmar ou fazer algum exercício pelas ruas de Austin é um movimento recorrente nas atividades desde as primeiras atividades durante o ano, o que torna o ato de se deslocar um elemento recorrente durante o processo de criação da videodança. Desta forma apresento algumas implicações desse ato que toca não só a criação de Montão de Coisa, como a própria metodologia da escola. Observo e problematizo essa prática a fim de pensar qual o papel dessas caminhadas dentro do processo de criação, tomando a caminhada como experiência estética e buscando entender como ela se torna elemento chave para a construção do filme.

Careri (2013) fala das caminhadas como forma de intervenção urbana. Nesse caso, entendo que cabe pensar como elas interferem em Austin? Trata-se de um processo de criação individual e coletivo que mobiliza, ao mesmo tempo, diferentes subjetividades e resulta numa prática estética de mão dupla, cuja dimensão de alteridade determina sua própria condição de existência.

As diversas experiências das oficinas de cinema são experiências na cidade, produzem encontros, permeados por tensões e consensos. Tratamos da ideia de alteridade para observar as tensões que permeiam este processo e que condicionam esta experiência e o fazer cinematográfico em meio a isso.

Paola Jacques em seu livro Elogio aos errantes (2012) trabalha a experiência urbana da alteridade, a autora aborda as práticas da errância urbana como um tipo de experiência sob ameaça, cada vez mais rara nas cidades contemporâneas:

(...) o que seria um novo choque contemporâneo: uma hábil construção de subjetividades e de desejos, hegemônicos e homogeneizados, operada pelo capital financeiro e midiático que capturou o capital simbólico e que busca a eliminação dos conflitos, dos dissensos e das disputas entre diferentes - seja 
pela indiferenciação, seja pela inclusão excludente promovendo, assim, a pasteurização homogênea ação e diluição das possibilidades de experiência na cidade contemporânea (JACQUES, 2012, p. 14).

Jacques me ajuda a pensar: "Qual Austin” participa do processo de construção destas imagens? Que experiências na cidade a ELC vivencia? Como isso toca o filme? Como isso toca os alunos e mediadores?

Nesta experiência de alteridade, de encontro, as tensões são parte das situações e é preciso buscar soluções para os pequenos problemas. Quem vai operar a câmera hoje? Quem vai conversar com o dono da venda para fazer uma gravação ali? Como vamos ocupar aquela passarela? Como faremos para gravar no trem e na estação? Estes espaços viram espaços de criação, de criatividade. A inventividade humana encontra terreno para se desenvolver utilizando o que se encontra ali à disposição.

Lembro de um encontro dos alunos com uma moça que panfletava para um político: estávamos na campanha eleitoral 2014 e era comum encontrar pessoas panfletando e balançando as bandeiras de partidos políticos pela passarela de Austin, certamente o lugar mais movimentado daquele bairro. Naquela semana uma moça chamou atenção dos alunos da ELC que por ali caminhavam catando imagens. Ela segurava os panfletos do político sem muito entusiasmo e, com o olhar distante, permanecia ali. Um grupo de alunos percebeu isso e ficou por ali, rodeando a moça. Em momento algum ela alterou sua expressão, entregar aqueles panfletos parecia a coisa mais entediante já feita. Um dos alunos pegou a câmera e fez algumas imagens da moça, focando especialmente seus gestos. Percebemos que os alunos fizeram as imagens sem pedir autorização à moça, foi quando os mediadores chamaram o grupo e explicaram a necessidade de se pedir autorização, de explicar o objetivo da gravação. De imediato eles resistiram, justificaram que poderiam perder as imagens, caso a moça não autorizasse a gravação, mas em alguns instantes aceitaram a imposição e voltaram, conversaram e pediram a autorização. Ela os deixou gravar. Na sala de aula, após assistirem às imagens, eles chegaram à conclusão que as melhores imagens foram feitas antes do pedido de autorização.

O conjunto de imagens desta moça, por escolha dos alunos, foi uma das mais estudadas durante o processo de criação dos gestos para a coreografia da 
videodança. As imagens foram trazidas para a sala, analisadas, transformadas em gesto, aperfeiçoadas (trabalhando ritmo, repetição e coerência) para posteriormente fazerem parte da coreografia de Montão de Coisa. O estudo com este gesto está demonstrado no conjunto de fotos que segue. A alteridade urbana reside nos encontros destes vários outros que, como, o escreveu Jacques (2012, p. 15), "por sua simples presença e prática cotidiana, explicitam conflitos e provocam dissensos".
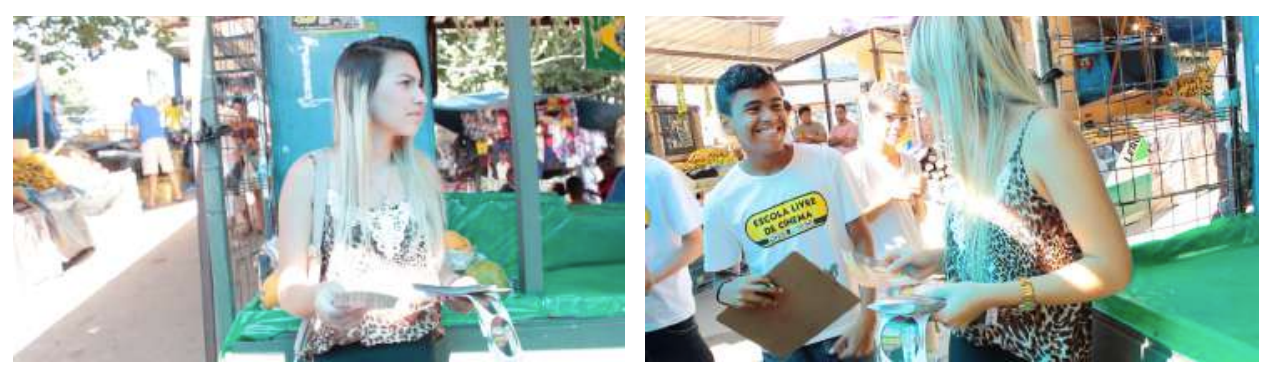

Imagem 38 - Frames a) e b): catalogando gestos em Austin: encontro com a moça distribuindo panfleto na
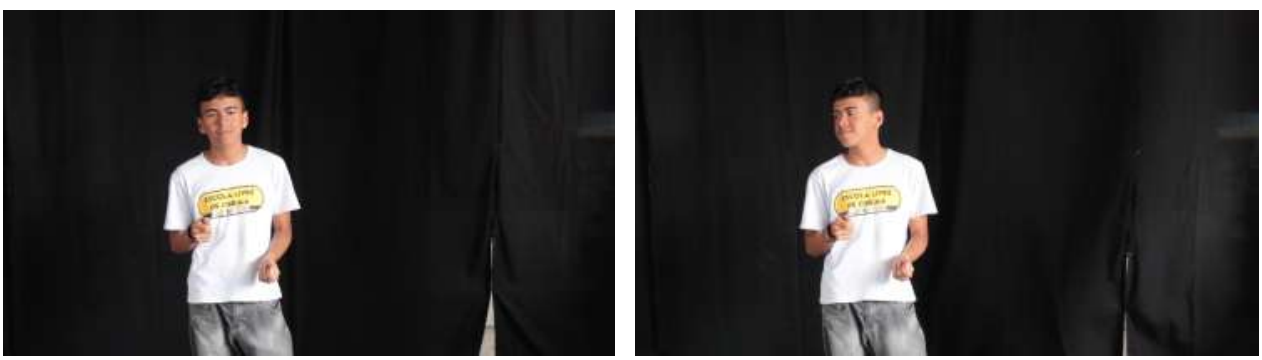

Imagem 39 - Frames a) e b): Estudo sobre os gestos das ruas - moça distribuindo panfletos \#1 (aula 44) créditos: coleção ELC
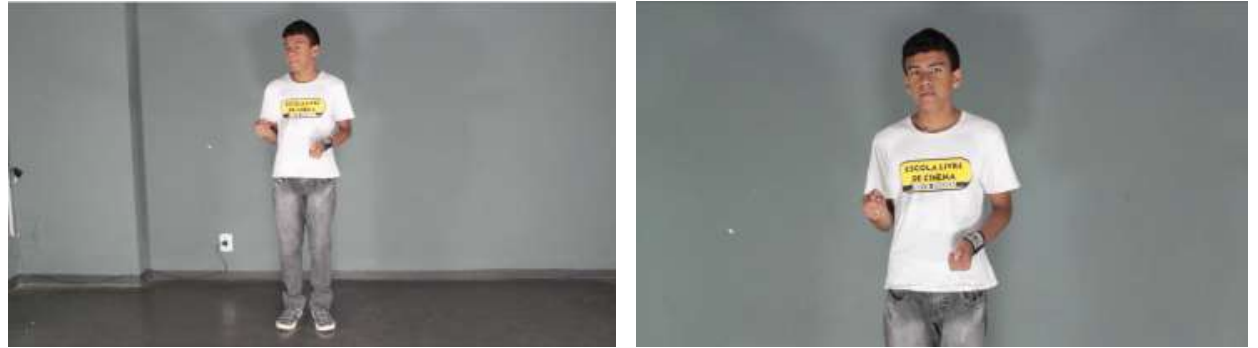

Imagem 40 - Frames a) e b): Estudo sobre os gestos das ruas - moça distribuindo panfletos \#2 (aula 49)créditos: coleção ELC 

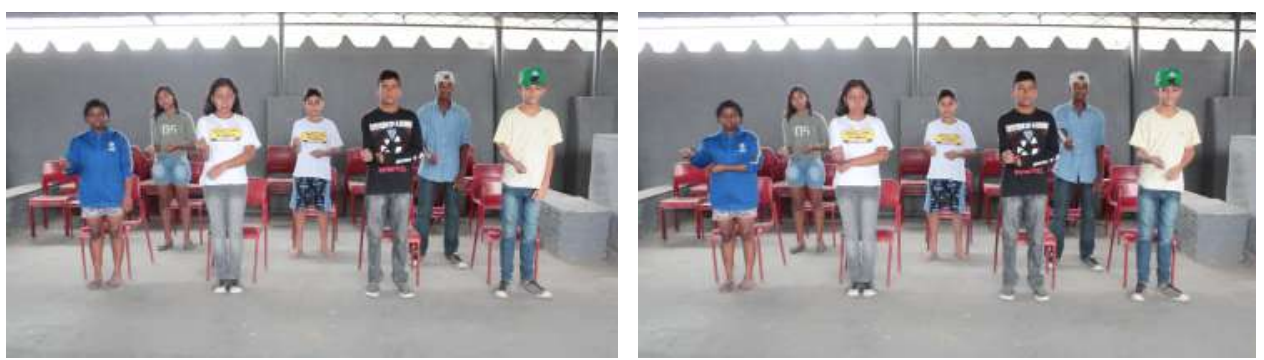

Imagem 41 - Estudo sobre os gestos das ruas - moça distribuindo panfletos \#3 (aula 50) - créditos: coleção ELC

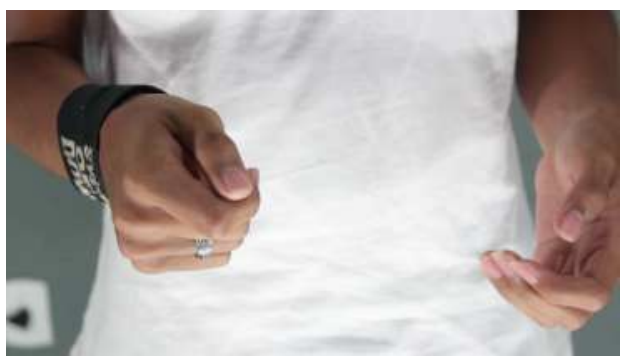

Imagem 42 - Estudo sobre os gestos das ruas - moça distribuindo panfletos \#4 (aula 51) - créditos: coleção
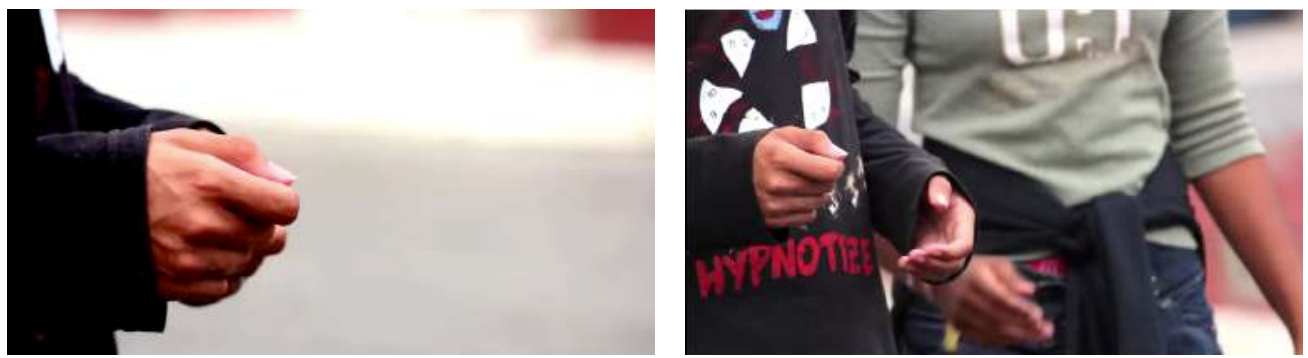

Imagem 43 - Frames a) e b): Execução do gesto na coreografia de Montão de Coisa - ELC, 2014

"O outro urbano é o homem ordinário que escapa - resiste e sobrevive - no cotidiano, na anestesia panificadora" (JACQUES, 2012, p. 15). A autora utiliza também as proposições de Certeau (1998) para pensar que este mesmo homem “inventa seu cotidiano, reinventa modos de fazer, astúcias sutis e criativas, táticas de resistência e de sobrevivência pelas quais se apropria do espaço urbano e assim ocupa o espaço público de forma anônima e dissensual" (p. 15).

A ideia do deslocamento como prática estética é muito cara para a arte, "é parte de uma estratégia de investigação no trabalho de diversos artistas, em muitos momentos da história da arte", relembra Brandão (2015, p. 128) em um mapeamento dos deslocamentos nas artes visuais em sua tese de doutorado 
apresentada na Faculdade de Belas Artes na Faculdade do Porto em Portugal. Brandão relembra o trabalho dos pintores de paisagem na busca por novos lugares para criar seus trabalhos e da importância da tinta acondicionada em tubos neste processo, que permitiu ao pintor sair de seu atelier. Na literatura, a obra de Charles Baudelaire com a figura do flâneur talvez seja a referência mais lembrada ao pensarmos no andarilho livre, naquele que se desloca pelas ruas anonimamente entre a multidão, observando a vida moderna. Sobre ele, Brandão $(2015$, p. 132) escreveu: "O flâneur poderia ser um artista à procura de inspiração ou um mero desocupado que se permitia perder seu tempo e seu caminho pelos acontecimentos e factos da vida urbana".

O flâneur de Baudelaire também se tornou fonte de inspiração para os dadaístas e surrealista, movimentos artísticos do começo do século XX e Susan Sontag no livro On photography (2005) traça uma relação entre o flâneur e o fotográfo, observando o ato de fotografar os espaços urbanos. Sobre o movimento das ruas registrados pelo cinema, o cinema dos irmãos Lumière já trazia em sua essência as riquezas da rua. Brandão (2015) relembra também a obra do cineasta português Manoel de Oliveira, em seu primeiro documentário Douro, Faina Fluvial (1931) e O homem da câmera filmar, de Dziga Vertov (1929).

O primeiro curta-metragem de Manoel de Oliveira, Douro, faina fluvial, de 1931, também explorava a dinâmica e riqueza que as imagens cinematográficas começavam a oferecer, ao filmar diversas cenas da área da Ribeira na cidade do Porto. O filme concentra-se em captar elementos da paisagem, seja o farol da Foz do Douro, a arquitetura da Ponte Luís I, o quotidiano da descarga dos barcos no porto, numa curiosa e rica captura de imagem que valorizava a presença do movimento, das ondas do mar, de automóveis, carros de bois, barcos, locomotiva ou o trabalho dos trabalhadores da Ribeira, a retirada das cargas dos barcos. O pintor e a cidade é outro filme de Oliveira, de 1956, que mostraria a mesma cidade do Porto, mas apresentando outras áreas, suas ruas, becos, igrejas, elétricos, caminhos de comboio ou arquitetura, mas também retorna à Ribeira e mostra com destaque a ponte Luís I (BRANDÃO, 2015, p. 135).

Com as caminhadas os dadaístas trouxeram a proposta de um evento artístico: deslocar-se pela cidade de forma contestadora, propondo uma nova forma de arte, que se realiza no próprio ato de propor o deslocamento, na busca por viver uma experiência coletiva de descobrir a cidade. Os dadaístas exploravam as áreas fora 
do centro da cidade, Careri (2013, versão kindle - posição 283) relembra que esta foi a primeira vez que a arte se impôs numa posição de rejeição dos "lugares célebres para reconquistar o espaço urbano". Já os surrealistas, levaram a prática dos dadaístas para outra dimensão: a ideia da deambulação, deixando-se perder pelos acontecimentos que encontrassem pelo caminho percorrido, a ideia era vivenciar as possibilidades do caminho. Brandão explica que, "André Breton e Louis Aragon, que participaram daquela excursão dadaísta, três anos depois empreenderiam um novo movimento, que iria usar a experiência de deslocamento no espaço como fonte para o processo de criação artística" (BRADÃO, 2015, p. 139).

A deriva situacionista seguia o movimento de aproximar a arte da vida, como faziam os dadaístas e surrealista, porém, com propostas que se mostravam mais questionadoras e marcadas por um sentido político. As intervenções nos espaços urbanos seriam ações pautadas em processos de criação e ação política. O grupo Letrista, integrado também por Guy Debord atuava em Paris e sua crítica voltavase para o fato de bastar uma proposta de anti-arte, "para ele a arte ao aproximar-se da vida com as experiências de deslocamento ou da deriva deve propor também um projeto de mudança revolucionário da sociedade" (BRANDÃO, 2015, p. 148).

Na década de 1960 os artistas passam a ver o caminhar como uma forma de intervenção na natureza e neste sentido alguns escultores passam a explorar o tema do percurso e encontramos aí os primórdios do paisagismo, "a land art transformou o objeto escultórico numa construção do território através de uma expansão à paisagem e à arquitetura" (CARERI, 2013, versão kindle - posição 336).

Trata-se das passagens do dadaísmo ao surrealismo (1921-24), da Internacional Letrista à Internacional Situacionista (1956-57) e do minimalismo à land art (1966-67). Analisando esses episódios, obtém-se uma história da cidade percorrida que vai da cidade banal do dadá à cidade entrópica de Smithson, passando pela cidade inconsciente e onírica dos surrealistas e pela lúdica e nômade dos situacionistas. A que é descoberta pelas errâncias dos artistas é uma cidade líquida, um líquido amniótico em que se formam espontaneamente os espaços de alhures, um arquipélago urbano a ser navegado indo à deriva. Uma cidade em que os espaços do estar são ilhas do grande mar formado pelo espaço do ir (CARERI, 2013, versão Kindle posição 283). 
Em seu livro Walkscapes - o caminhar como prática estética (2013), o italiano Francesco Careri trabalha a questão do caminhar como um prática estética e apresenta uma espécie de tratado retroativo sobre o caminhar, traçando um histórico que vai desde os primeiros nômades até os artistas da land art dos anos 1960/1970. Paola Jacques classificou o trabalho de Careri no prefácio de Walkscapes como "uma longa genealogia caminhante" (2013, p. 7).

Careri também é um caminhante, um artista que procura desenvolver nesta prática suas ações. Fez parte do grupo Stalkers, que buscava andar pelas ruas nos arredores de Roma, os chamados espaços intermediários em torno da cidade, na sua margem transformando aqueles locais em espaços urbanos praticados. $\mathrm{O}$ Stalker praticou as transurbâncias, perdendo-se no meio das amnésias urbanas. Este autor (2013, versão kindle - posição 347) pensa o caminhar como "um instrumento estético capaz de descrever e modificar os espaços metropolitanos que muitas vezes apresentam uma natureza que ainda deve ser compreendida e preenchida de significados, antes que projetada e preenchida de coisas".

\subsubsection{O mundo que se filma}

Utilizando ainda as aulas 16 e 18 como exemplo, retomo aqui o exercício que consistiu em fazer uma caminhada silenciosa pelas ruas de Austin, para pensar estes espaços praticados.

Talvez o trajeto que a Luísa vá sugerir seja um trajeto muito comum pra vocês, muito corriqueiro. Mas tentem fazer um exercício: vocês estão em outro momento do dia de vocês, um momento de aula, tentem exercitar um outro olhar para este espaço, porque às vezes tem coisas que a gente vê, mas que a gente não olha. Tentem perceber esse lugar de uma outra maneira, façam esse exercício, sabe? Tem que ser uma coisa que vai partir de vocês. Como a gente percebe um lugar que é tão ordinário, tão comum no nosso dia a dia? Como a gente pode perceber outros elementos que na pressa do dia, no movimento automático de ir pra escola, acaba passando batido. Pense que vocês estão indo agora pra olhar. (anotações sobre a fala do mediador - aula 16).

O percurso feito pelos alunos perseguiu um propósito: observar as ruas de Austin com outro olhar. Além disso precisamos considerar que, neste caso, tratase de um percurso traçado por alguém que não vivencia aquela cidade, para ser 
feito por pessoas que têm suas práticas cotidianas e vivências ali (a escola, os amigos, a casa), isso nos leva a pensar na construção de um espaço. Outro dado relevante é o fato de que os alunos não acreditam que Austin possa ter elementos para criação para um filme. Sendo assim, estamos falando de um processo de aproximação pelos mediadores e de ressignificação, para os alunos. Deste modo, retorno a Careri (2013, versão Kindle - posição 272) para pensar que "modificando os significados do espaço atravessado, o percurso foi a primeira ação estética que penetrou os territórios (...) a partir desta simples ação foram desenvolvidas as mais importantes relações que o homem travou com o território". E neste sentido, trazendo esta colocação para a experiência de Austin, podemos pensar a relevância das caminhadas exploratórias feitas por alunos e mediadores durante o processo.

Jaques (2012) parte da experiência errante no espaço urbano, para a qual importa exatamente o que é despretensioso, o que se dispõe a acontecer. A experiência é uma peça chave para entender seu pensamento, pois é por meio dela que as narrativas urbanas surgem e com ela que encontros com a alteridade se tornam possíveis.

A principal questão em disputa, entretanto, está além da experiência da alteridade em si, mas entrando no campo simbólico (...). $\mathrm{Na}$ verdade, a principal potência em questão está na construção e na (contra)produção de subjetividades, de sonhos e de desejos. Assim, as narrativas urbanas resultam dessas experiências realizadas pelos errantes, sua forma de transmissão e compartilhamento, podem operar como potente desestabilizador de algumas das partilhas hegemônicas do sensível e, sobretudo, das atuais configurações anestesiadas dos desejos (JACQUES, 2012, p. 11).

Na criação das imagens a experiência com o urbano na ELC transforma o lugar em espaço e trabalha numa perspectiva de uma cidade mais lúdica e experimental para os alunos e mediadores, afastando-se da espetacularização, das imagens carregadas pelo discurso do lugar periférico, do lugar dormitório, da falta. Ao invés disso, envolve a relação entre corpo e o movimento, tão cara à videodança. Mistura o movimento da coreografia com o movimento cotidiano das ruas, sem que um cenário seja montado para isso. O cenário, neste caso, é o cotidiano de Austin. 
Essas narrativas errantes são narrativas menores, são micronarrativas diante das grandes narrativas modernas; elas enfatizam as questões da exploração, do corpo e da alteridade na cidade, uma complexidade e multiplicada de sentidos que confronta qualquer 'pensamento único' ou consensual, como o promovido hoje por imagens midiáticas luminosas e espetaculares das cidades. (JACQUES, 2012, p. 20-21)

Neste sentido, busca-se um afastamento proposital do lugar mais familiar em busca de uma condição de estranhamento, de uma alteridade. É o encontro com o outro e os vários outros, com a diferença. Diante desta dinâmica proporcionada pelos dispositivos em um processo de criação no espaço urbano a cidade serve como um terreno de jogos e experiência ${ }^{33}$. A presença dos alunos fazendo um filme pelas ruas de um lugar que não é acostumado com a arte provoca também uma aproximação entre a vida, o território e os artistas (eles, os alunos e mediadores). Nas palavras de Jackson (1994), “As ruas não conduzem a lugares, elas mesmas são lugares” (In: CARERI, 2013, versão kindle - posição 182).

O deslocamento pelas ruas é permeado de ações que podem ser lidas como instrumentos estéticos, são ferramentas que acabam auxiliando os alunos a explorar e transformar os espaços percorridos. Neste sentido, recorro novamente a Careri (2013, versão kindle - posição 241-262), que elabora um jogo de palavras que servem para nomear estas ferramentas. $\mathrm{O}$ autor apresenta estas palavras em três colunas que podem ser lidas de forma aleatória e também entrelaçada. A partir da experiência de criação da ELC utilizei algumas combinações em uma tabela própria, numa escolha que foi fruto da minha leitura do processo, para pensar os exercícios de criação propostos pela escola e que tiveram relação direta com o caminhar ou o deslocar-se por Austin. As palavras que formam as colunas abaixo são, em sua maioria, contraditórias e úteis para pensar o paradoxo e as tensões deste tipo de processo, do ato de criação. Para pensar a experiência da ELC vale seguir as colunas e combiná-las de forma aleatória, por exemplo “caminhar - orientar-se - perder-se". O conjunto de palavras combinadas representa uma ação.

\footnotetext{
${ }^{33}$ Durante a redação desta tese utilizei as palavras desafio, exercício e jogo como sinônimos para os dispositivo usados pela ELC ou para falar no que ele consiste e provoca.
} 


\begin{tabular}{|c|c|c|}
\hline caminhar & orientar-se & perder-se \\
\hline seguir & um instinto & \\
\hline celebrar & os perigos & \\
\hline escutar & os buracos & \\
\hline observar & os espinhos & \\
\hline guiar & os odores & \\
\hline perceber & os sons & \\
\hline imergir & vagar & ir adiante \\
\hline compreender & valores simbólicos & \\
\hline atribuir & valores estéticos & \\
\hline
\end{tabular}

Tabela 2 - Jogo de palavras para pensar a caminhada como experiência estética - versão adaptada para esta tese, com base em Careri (2013)

Os encontros na ELC aconteceram entre a sede da escola e as ruas de Austin. Não era raro que em um encontro uma parte da aula fosse feita em sala de aula e outra parte na praça, por exemplo. Desde os primeiros encontros os estudantes já sabiam que existia uma grande probabilidade de que os exercícios práticos fossem feitos na rua, no entanto, este fato nunca foi rejeitado por nenhum deles. Somente quando o processo de criação da videodança passou a ser feito de forma mais sistematizada eles passaram externar dúvida quanto à possibilidade de encontrar em Austin os elementos necessários para a construção do filme. No entanto, prosseguiram aceitando o desafio.

Percebo que a ELC propõe uma aproximação do olhar com o território investindo em exercícios que trabalham a percepção e, sobre isso, o uso dos dispositivos técnicos assume importância no processo, eles estão entre os alunos e o espaço a ser filmado. Alguns deles são construídos na escola, como a câmera presa em um eixo que gira, para gravar as imagens da videoinstalação \#Circulando. Os exercícios atuam de forma a fazer com que os alunos observem o espaço, fazendo escolhas e enquadramentos, trabalhando a espacialidade, o deslocamento e a paisagem.

Ao longo dos capítulos desta tese tracei um caminho que me permitisse perpassar o cinema experienciado na ELC, a fim de investigar seu processo de 
criação e as relações que permeiam este fazer durante o surgimento das ideias. Isso significou, de imediato, levar em conta algumas colocações feitas pelos mediadores da escola nos primeiros encontros, para então prosseguir: a primeira consideração é que na escola o cinema assume significado diverso ao que comumente se entende como um cinema convencional, aquele que ocupa um lugar numa sala escura, com uma grande tela, cadeiras e um bilhete de entrada. Além disso, ele também assume um lugar diferente daquele tomado pelos filmes com narrativas lineares e ligados a uma história.

São esses os elementos que instigaram a construção do próximo capítulo, último desta tese. Nele discuto a ideia de cinema expandido trazendo-a para entender como o cinema, enquanto arte, expande relações - dos alunos e mediadores entre si, consigo mesmos, com a comunidade e com o próprio cimena. 


\section{5: Para pensar um outro cinema expandido}

\subsection{Um cinema expandido}

O cinema aqui não é o filme exatamente como a gente está acostumado a ver (...). (anotações sobre a fala do mediador aula 1).

Ao pensar nos estudantes de Austin, cabem as perguntas: Qual seria, para eles, o lugar convencional do cinema e qual seria a alternativa a isso? Ao imaginar um cinema convencional estou pensando naquele que seria a provável resposta imediata à pergunta: “o que é cinema para você?”.

No livro Un etnologo al bistrot (2015), Marc Augé trabalha as diversas conotações que o bistrô pode assumir e a diversidade de frequentadores daquele espaço. Apegando-se ao peso da palavra e a seus possíveis significados, Augé trabalha com o significado que o bistrô assume em várias culturas, de acordo com o contexto. $\mathrm{O}$ encontro com este livro me ajudou a pensar o cinema a partir do que estou propondo neste início de capítulo, investigando como o cinema é encarado pelos alunos da ELC e como a visão inicial que eles têm de cinema conduz ao caminho de um encontro com uma outra forma possível de pensar o cinema, de fazer, de se relacionar com ele.

Ao longo dos encontros e especialmente durante o desenvolvimento de alguns exercícios de criação era comum perceber a apreensão de um ou outro aluno diante de uma possibilidade imaginada de certo ou errado, esta comumente era trazida por eles mesmos. Parecia-me ser difícil para eles acreditar que ali não havia uma única forma de filmar, de fazer um filme ou, uma forma correta de trabalhar os gestos para uma coreografia.

Um exemplo disso pode ser pensado a partir de uma situação que aconteceu durante a aula 46, enquanto alunos e mediadores trabalhavam a coleção de gestos. Naquele dia o trabalho de criação dos gestos estava acabando e uma nova etapa se iniciava: cada aluno já havia escolhido seu gesto e precisava executá-lo para os demais colegas, a ideia era que todos conhecessem os gestos uns dos outros. Mas ao executarem os gestos, os alunos agiam de forma contida, como se no meio do 
processo já esperassem algo ou algum comentário. Diante disso a mediadora responsável pelas aulas de cinema, corpo e dança exclamou: "Executem o gesto. E não precisa olhar pra mim. Eu não estou aqui para julgar o gesto de vocês" (anotações sobre a fala da mediadora - aula 46).

Quando a gente realiza o gesto, temos que acreditar que estamos fazendo uma coisa importante, ninguém sabe de onde vem essa referência. Não vai ter uma legenda. $O$ mais importante é como a gente vai compondo essa coreografia. (...) E inclusive, vocês terão que ensinar para os outros o gesto de vocês. Cada um entende de um jeito, mas todos precisam saber explicar (anotações sobre a fala da mediadora - aula 46).

Ao complementar sua fala a mediadora lança algumas perguntas, tais como: "Qual o interesse neste gesto? Por que vocês se interessaram por este gesto? Porque o Edson se interessou por aquela menina?" (anotações sobre a fala da mediadora - aula 46). Esta exposição pode ser lida como uma tentativa de dizer: seja qual for o gesto escolhido, não existe certo ou errado, existe um gesto que passou por uma escolha e que agora precisa ser assumido. É a coleção destes gestos que vai formar a coreografia e esta, a videodança. Assumir a autoria de algo parecia ser uma tarefa improvável para os alunos.

Não é minha pretensão trabalhar com definições estanques, tampouco determinar o que seria $o$ cinema para a escola de cinema, mas sim, o que este pode ser. Cada aluno carrega consigo uma forma de ver o cinema e de maneira geral é através da experiência estética que ele assume outros significados, outras formas de leituras, mais amplas, rizomáticas, híbridas. Estamos então, trabalhando no movimento de dar a este cinema um outro lugar, uma outra possibilidade de leitura, a possibilidade de estender seu significado para outros sentidos. Não se trata de um formato específico, mas de tendências de estruturação e escrita que visam a ampliação de suas fronteiras e suas relações. Desta forma, diante das análises já apresentadas ao longo deste texto, proponho neste capítulo pensar a experiência da ELC à luz da categoria cinema expandido. Trata-se aqui de tensionando uma expansão que possui uma certa inspiração no cinema que nasce das tensões com a arte contemporânea e com as novas tecnologias da imagem, mas que é constituído por um contexto diverso daquele que surge no início dos 
anos 1970, com o nascimento da videoarte, para perceber como esta prática em meio a esta experiência com o cinema estente as relações envolvidas.

\subsubsection{Entre Maya Deren e o percurso pelas ruas de Austin}

Quando o mediador inicia sua fala informando aos alunos que os filmes que eles vão conhecer são diferentes dos que estão acostumados a ver (aula 1), ele prepara o caminho para falar do cinema que surge da relação com a arte contemporânea, de um cinema que é pensado e feito para ser exposto, exibido em outros espaços.

Desta forma o cinema surge na ELC sendo pensado a partir do seu lugar de exibição e através dos dispositivos técnicos envolvidos. O processo de criação e o produto entram em evidência e ao conversarem sobre a produção desses vídeos, os mediadores enfatizam a escolha pela construção de um filme que não tem como objetivo contar uma história, iniciando assim um caminho de encontro com uma outra forma de produzir imagens. A conversa sobre este assunto foi ilustrada com as imagens das videoinstalações produzidas pela ELC nos dois últimos anos.

Isso é uma das características do trabalho que vamos fazer aqui: não estamos necessariamente apegados a uma necessidade de contar uma história, a gente quer experimentar as imagens e as possibilidades, o que podemos fazer, o que é interessante, $o$ que é diferente do que o que mais temos visto por aí (anotação sobre a fala do mediador - aula 1 - grifos meus).

O encontro da ELC com a arte contemporânea e a apresentação dos processos criação e produção de outros anos, gerou uma aproximação entre os alunos e uma forma de ver o produto audiovisual a partir de um contexto maior, onde a experiência com a criação, o nascimento das ideias e o processo de transformá-las em imagens ganham destaque. Acredito ter sido esta uma das primeiras vezes em que os alunos encararam a experiência tão citada pelos mediadores, como uma experiência estética. Esta atua numa frente dupla: trabalhar os aspectos estéticos e subjetivos daquele grupo com relação à criação e também proporcionar aos alunos e mediadores pensarem no suporte e na exibição. 
Neste sentido as aulas seguiram trazendo para a sala outras referências, especialmente no trabalho com a produção da videoarte e da videodança. No entanto, não foi feito um trabalho de pensar estes movimentos de forma cronológica, apresentando os expoentes de cada vertente e suas obras, mas um trabalho pautado por temas caros à relação do cinema com a arte contemporânea e ligados ao processo de criação. Esta escolha apresentou aos alunos a base para se criar e compor uma videodança. A ideia das imagens em movimento tomou forma ao longo das aulas, através do encontro com o fazer, que naquele ano foi pautado pela interrelação entre o cinema e a dança.

O contexto de produção que se evidenciou durante as décadas de 1960 e 1970 no campo do cinema foi marcado pela relação com as novas tecnologias emergentes. Este foi um período fértil para que cineastas, coreógrafos e artistas visuais desenvolvessem seus experimentos, num intercâmbio entre as mídias. Ainda na década de 1970 o norte-americano Gene Youngblood publicou seu livro Cinema Expanded, obra de referência para os estudos sobre o cinema expandido. Nele o autor aponta o que estava acontecendo "no âmbito do cinema experimental underground" (MACHADO, 2008, p. 66) e elabora o conceito de cinema expandido, argumentando que o conceito tradicional do cinema havia “explodido". Esta expansão notada por Youngblood toma como base as então formas de projeção do cinema e o caráter híbrido da sua forma de criação. Sobre este período Arlindo Machado (2008) relembra algumas obras emblemáticas:

Alguns cineastas faziam filmes para serem projetados não mais em telas, mas nas roupas brancas de bailarinas em situações performáticas; Stan Brakhage realiza filmes simplesmente colando asas de borboletas sobre uma película virgem; Ken Jacobs propõe um filme (Tom Tom, the Piper's Son, 1969) em que parte dele deveria ser projetada com película fora da grifa e, portanto, sem exibição dos fotogramas; Andy Warhol concebe o seu Chelsea Girls para duas telas paralelas e simultâneas, resgatando a famosa experiência de Abel Gance com seu Napoléon, de 1927; alguns filmes já não eram feitos com câmeras, mas diretamente modelados e animados em computadores (como toda a obra dos irmãos Whitney), enquanto outros (os de Nam June Paik, por exemplo) não usavam mais películas, mas fitas eletromagnéticas e eram exibidos em aparelhos de TV (MACHADO, 2008, p. 66-67).

Os aspectos estéticos e de criação deste cinema podem ser vistos em uma proximidade com o primeiro cinema, quando não se tinha ainda uma forma 
padronizada de se produzir e exibir os filmes e especialmente pelo caráter experimental. Machado (2008, p. 67) aponta como exemplo o cinema de Thomas Edison, que era exibido em visores individuais. Havia ainda as obras que passavam por processos de montagem durante sua exibição, em que a fusão, a sobreposição, as janelas simultâneas eram trabalhadas em tempo real, enquanto o filme era exibido e montando com o manuseio de seus fragmentos, vindo dos diversos rolos que cada filme poderia conter.

Essas imagens deslocadas, sem lugar definido na contiguidade da projeção, sempre foram um enigma na historiografia do cinema e somente agora se está começando a entendê-las como sintomas dessa fundamental heterogeneidade dos primeiros filmes (MACHADO, 2008, p. 67).

Desta forma podemos traçar um paralelo entre heterogeneidade dos primeiros filmes e o caráter híbrido das obras contemporâneas, quando são frutos de experimentos estéticos, da manipulação das imagens e dos dispositivos técnicos, de forma a expandir o conceito de cinema que o modelo industrial havia cristalizado. Depois dos estudos e dos experimentos da década de 1970 a ideia de expansão continuou ganhando espaço e os meios e as artes, neste processo, continuaram num processo híbrido, com suas fronteiras borradas. Percebemos um intercâmbio de técnicas e ferramentas, e como fruto deste processo passamos conhecer obras como esculturas em campo expandido, fotografia expandida, vídeo expandido, documentário expandido. Neste cenário as contribuições do francês Raymond Bellour (1997) nos ajudam a pensar nas passagens entre os meios, por exemplo, entre a fotografia, o cinema, o vídeo e as mídias digitais. Ao refletir sobre isto, Bellour nos convida a compreender melhor as tensões e ambiguidades que operam neste caráter híbrido dos meios, conforme comenta Machado (2008):

As fronteiras formais e materiais entre os suportes e as linguagens foram dissolvidas, as imagens agora são mestiças, ou seja, são compostas baseadas em fontes as mais diversas: parte delas é fotografia, parte é desenho, parte é vídeo, parte é texto produzido em geradores de caracteres e parte é modelo matemático gerado em computador (MACHADO, 2008, p. 69).

Foi neste cenário artístico da década de 1960 que surgiu também uma proposta interdisciplinar e coletiva a partir da aproximação entre o cinema e as 
artes do corpo, da comunhão entre estas duas linguagens nasce a videodança. Cerbino e Mendonça (2012) afirmam que este encontro trabalha num alargamento da percepção do tempo e do espaço através do vídeo e Brum (2012, p.109) aponta a videodança como "um híbrido, nascido de um diálogo entre a dança e o vídeo, no qual essas linguagens se tornam indissociáveis, como uma obra coreográfica que existe apenas no vídeo e para o vídeo”.

Este pensamento "transversal entre linguagens" (BRUM, 2012, p. 95) envolve artistas visuais, bailarinos, músicos, coreógrafos, filmmakers, arquitetos, pintores, escultores, escritores. "Trata-se de uma cena que emerge da aproximação de artista do audiovisual e da dança que, juntos, encontram no vídeo um manancial repleto de novos recursos para realizar suas ideias" (BRUM, 2012, p. 77). A grande produção inicial da videodança é composta por registros que estes profissionais fizeram de seus trabalhos, Brum (2012, p. 96) aponta o vídeo Hand Movie, de 1966, dirigido por William Davis e coreografado por Yvonne Rainer como um exponencial desta época.

Com a videodança as questões referentes à câmera que capta o movimento do bailarino vêm à tona; a dinâmica da filmagem é pautada pelo movimento da coreografia e a coreografia é pensada para o vídeo. Pensando nesta dinâmica acredito ser exitoso retomar ao que é considerado vanguarda na videodança. No caso da ELC e do processo de criação de Montão de Coisa, o estudo do trabalho de Loïe Fuller e Maya Deren serviram com base para iniciar os alunos no universo da videodança.

Foi com o movimento sinuoso de um tecido na frente do espelho que a bailarina Loïe Fuller descobriu que o efeito da luz do sol naquele tecido resultava em um composição interessante e a partir de então experimentou dançar com trajes longos e esvoaçantes para esculpir a luz. Spanghero (2003, p. 30) comenta que o exercício de Fuller é algo como um trabalho de tecido e luz, a serpentine dance da bailarina rendeu uma adaptação que se tornou o primeiro filme colorido da história, o filme produzido por Thomas Edison em 1896 que recebeu o nome de Annabelle Serpentine Dance. Hoje com a difusão de obras antigas em plataformas como o youtube, os alunos da ELC conheceram Annabelle Whitford Moore executando uma dança similar à de Fuller. "[Ela é] autora de contribuições duradouras na concepção de luz para o teatro, técnicas cinéticas e figurino" comenta Spanghero (2003, p. 31). 
Em sala, alunos discutiram sobre o contexto da época em que os experimentos foram realizados, foram incentivados pela mediadora a pensar o processo de criação das imagens, ou seja, como o movimento dos tecidos e da coreografia foi eleborado. O vídeo foi visto e revisto algumas vezes, tanto pela mediadora das aulas de cinema, corpo e dança, quanto pelos mediadores que trabalhavam a linguagem cinematográfica.

O interesse de Füller pelos efeitos da luz e sua relação com a dança renderam o patenteamento de várias invenções no campo da iluminação, como o teste da primeira mistura química para géis, o uso do sal luminescente para criar efeitos de luz. O palco interessava à bailarina tanto pela dança, quanto pelas técnicas ali desenvolvidas. Seu processo de criação envolvia um experienciar na criação de técnicas e novas fronteiras para a dança.

Outra referência paulatinamente trabalhada ao longo do projeto daquele ano na ELC foi a ucraniana Maya Deren. Com Daren a convergência entre cinema e dança foi explorada pelos alunos num processo que envolveu conhecer a obra, desmontar e experienciar fazendo. A dedicação de Maya Deren aos estudos do movimento está localizada temporalmente no nascimento da dança moderna e das primeiras cinematografias nesta área.

O experimentos desenvolvidos por Maya Deren resultaram em importantes obras e apresentam um estudo do tratamento da iluminação e das perspectivas de espaço e tempo, ultrapassando os objetivos de documentação e entretenimento e fazendo de Daren uma das mais importantes cineastas da história do cinema da América do Norte, seu continente de imigração. Spanghero (2003) relembra que foi Deren quem liderou a revolução ocasionada pelo surgimento do equipamento $16 \mathrm{~mm}$, que trouxe o nascimento do filme como uma expressão artística pessoal.

Suas obras Private life of a cat (1947), Meshes of the Afternoon (1943), Ritual in Transfigured Time (1943) e especialmente A Study in Choreography for Camera (1945) foram trabalhadas pelos mediadores junto aos alunos. Neste último filme citado, Daren cria uma espécie de geografia do espaço com base no movimento do bailarino, a ideia de tempo é trabalhada de forma deslocada do espaço, que muda de acordo com o movimento em elipse executado pelo bailarino. O resultado do estudo feito pelos alunos da ELC a partir deste vídeo foi publicado pelos mediadores em um vídeo de cerca de um minuto, onde os alunos experimentam trabalhar o tempo do movimento de forma diversa ao tempo do 
espaço. Uma aplicação do trabalho de Daren e das técnicas de montagem como o raccord, com elementos do contexto dos alunos, em grande parte usando o espaço da escola.
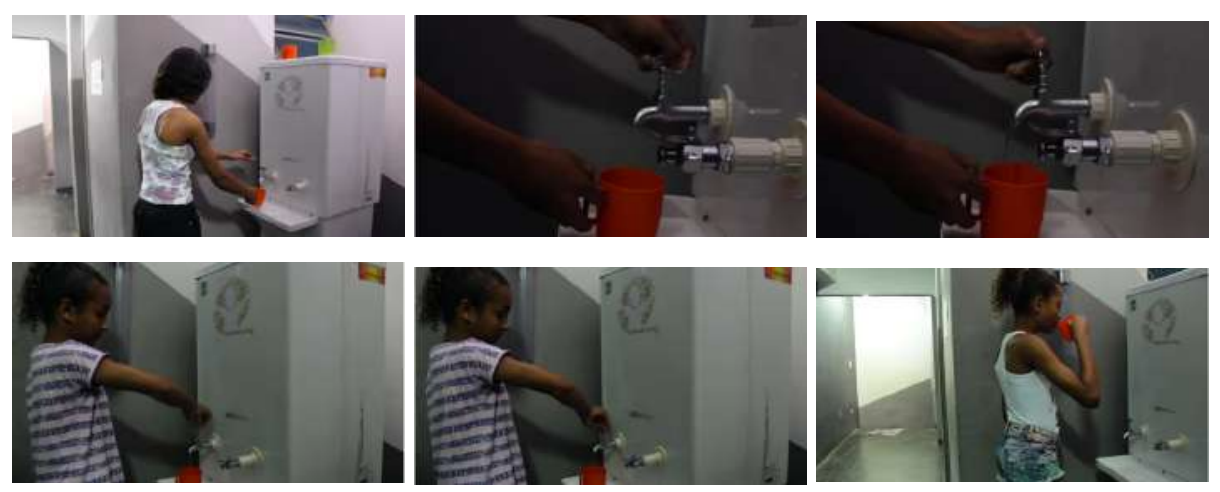

Imagem 44 - Conjunto de frames do vídeo que compila dos exercício de raccord feitos em sala - Créditos: ELC

O conjunto de frames acima (imagem 43) apresenta fragmentos do exercício pautado no estudo das técnicas usadas por Daren no vídeo $A$ Study in Choreography. Neste experimento os alunos se organizaram em duplas e planejaram um vídeo que teria um movimento executado por um ator, a proposta era filmar 3 planos diferentes da mesma ação. Após a filmagem o material foi editado juntos com os alunos, no programa de edição de vídeos Adobe Premiere, utilizando a técnica do Raccord. O trabalho feito na aula 9 e serviu como base para o trabalho com a coreografia pensada meses depois.

Montão de Coisa trabalha o tempo da ação e o tempo cinematográfico para pensar a coreografia através da câmera. Neste sentido, a câmera guia o olhar para fazer ver melhor a coreografia, em um trabalho que foi feito com o uso de duas câmeras gravando simultaneamente a coreografia em execução e atuando na constante alternância entre os detalhes e a distância. É desta forma que a câmera dança com os alunos em cena e eles, que são os bailarinos, se colocam no espaço e tempo da câmera.

Ao ter sua execução seguida pela câmera a coreografia percorre pontos emblemáticos no imaginário de Austin e apresenta cenários que foram explorados ao longo do ano de desenvolvimento do projeto e do processo de criação da videodança. A predominância dos movimentos em elipse parece fazer com que o lugar esteja sempre agregando novos elementos, trabalhando a coleção de imagens feitas pelos alunos e transformada em gestos, como nos frames a seguir. 


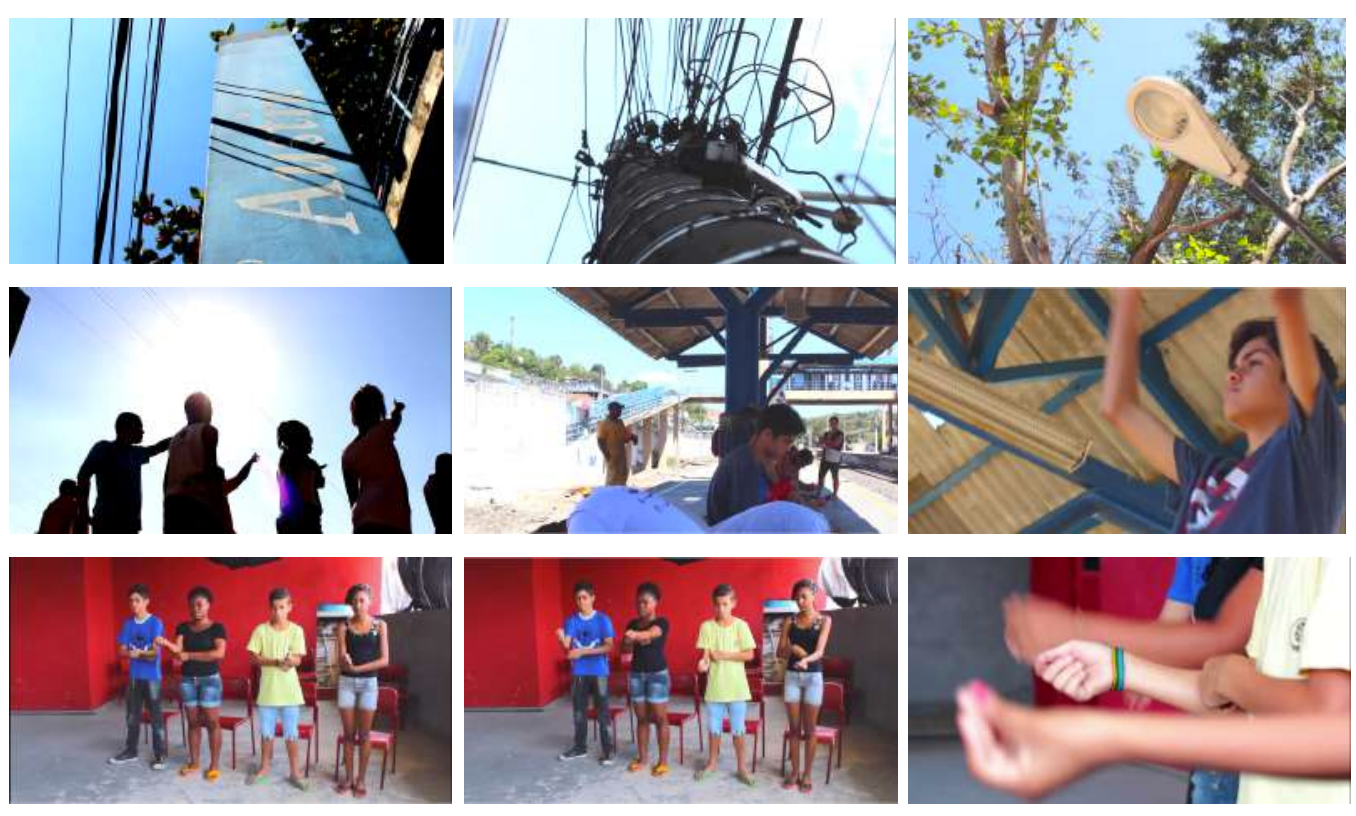

Imagem 45 - Conjunto de frames da videodança Montão de Coisa - créditos: ELC

\subsection{Um cinema da inventividade}

Durante a aproximação com o processo de criação de Montão de Coisa, feita no capítulo 3 desta tese, apresentei uma leitura desse movimento através de uma abordagem dos dispositivos de criação usados pela ELC, colocando estes como disparadores de situações e ações de criação, o que se apresentou como uma espécie de making off do processo da videodança, um mapeamento suas imagens, que revelam ao mesmo tempo as relações que ali se estabelecem. Retomo este ponto para iniciar esta subseção no movimento de fazer uma leitura deste fazer a partir das práticas videográficas (DUBOIS, 2013) perseguindo a hipótese de que o cinema da ELC pode ser lido como um cinema da inventividade.

Para isto, tensionei pensar o vídeo ${ }^{34}$ como dispositivo, ou seja, também como aquele que conduz a situações, gera "novos problemas" a serem resolvidos. Neste sentido, me aproximo também de outra ideia desenvolvida por Dubois (2013), que posiciona o vídeo como estado do pensamento, “o vídeo pensa (ou permite

\footnotetext{
${ }^{34} \mathrm{O}$ que entendo como video nesta seção refere-se ao dispositivo de escrita das imagens: uma instalação pode ser um video, uma videodança e uma coleção de videos pode formar uma videoinstalação. Ao longo da tese é recorrente encontrarmos termos como video e filme para se referir a um produto audiovisual, uma obra.
} 
pensar) o que as imagens são (ou fazem)" (DUBOIS, 2013, versão kindle posição 220). Segundo o autor, “o pensador (...) constrói suas ideias manejando instrumentos novos - a câmera, a ilha de edição, o computador -, invocando ainda outros suportes de pensamento: sua coleção de fotos, filmes, vídeos, discos - sua midiateca, enfim" (DUBOIS, 2013, versão kindle - posição 160).

Refletindo sobre o processo da ELC e pensando sobre esta imagem que nasce de um exercício de reflexão a partir de outras imagens ou de uma midiateca, me aproximo do texto 12 etapas e uma lição para se fazer um filme-carta (em tempos de whatsapp) (2013), escrito por Isaac Pipano. Nele o autor apresenta uma lista de 12 passos para se fazer um filme-carta. Como o título sugere, a escrita deste é pensada para ser feita por alguém que vivencia este momento da cultura audiovisual contemporânea: do whatsapp, dos canais no youtube e das câmeras de celular. O filósofo Michel Serres chamou de "polegarzinha" (2013) o estudante desta geração, fazendo uma alusão ao uso dos dedos polegares para digitação na tela dos celulares, smartphones e tablets. Serres (2013) defende que qualquer que seja o trabalho que envolva uma escola (e aqui nos cabe pensar a escola de cinema) ou uma relação de ensino, se faz necessário conhecer esta nova geração que habita o virtual. "Com o acesso às pessoas pelo celular e com o acesso a todos os lugares pelo GPS, o acesso ao saber se abriu. De certa maneira, já está o tempo todo e por todo lugar transmitido" (SERRES, 2013, p. 26).

Em sua lista Pipano (2013, p. 29) surgere que se aprenda a escrever com a câmera e ao mesmo tempo provoca o leitor informando que este processo de escrita não cessa, quanto mais se aproxima, mais encontros são provocados e, neste sentido, argumenta que a maior fonte de inspiração para esta escrita é o encontro com o mundo. "Nunca deixe de ver o mundo com um dialeto impronunciável” (p. 29). Com esse movimento de leitura, desconstrução e escrita com a imagem, o fazer assume um "senso constante de ensaio, [de] experimentação, [de] pesquisa e [de] inovação” (DUBOIS, 2013, versão kindle posição 991) tão recorrentes ao vídeo e que abre um espaço para o risco da rasura, do rascunho de forma positiva e perfeitamente aceita. Percebo que o que une estas três situações apresentadas: a lista feita por Pipano, o contexto da Polegarzinha debatido por Serres e a liberdade das práticas videográficas apresentadas por Dubois é o caráter de inventividade que as produções, fruto deste cruzamento apresentam. Sendo assim, o trabalho de uma certa potência inventiva dos alunos 
da ELC se faz na medida em que estes projetos se transformam em experiência de criação e experiência estética.

Entendo que o cinema na ELC, visto da perspectiva de seu processo de criação, pode ser identificado como um cinema da inventividade, que trabalha a questão do encorajamento estético, da experiência da alteridade, um cinema que surge e é trabalhado dentro de um processo de criação em que se procura valorizar e utilizar o potencial de inventividade contido em cada situação e a ser desenvolvido por cada sujeito. Com a busca pela aproximação com um conhecimento da linguagem e dentro da potência desta linguagem se usa as ferramentas e manipula-se o próprio cinema, trabalhando os desafios propostos nos exercícios, criando individual e coletivamente. Atento ainda para a defesa, nesta pesquisa, do potencial criativo e de inventividade como inerentes ao homem, isto é, qualquer um pode desenvolver. Na ELC ele é potencializado porque é fruto de uma experiência.

Em um primeiro encontro dos alunos com o cinema notamos ter havido um estranhamento e, com isso, surgiram as questões referentes ao distanciamento (dos alunos com um cinema que se apresenta, da compreensão de que aquilo é cinema e um distanciamento do fazer do ponto de vista de uma perspectiva autoral). Este cenário de criação nos permite uma leitura de um encontro com a imagem, em que esta é oferecida como experiência, em que uma situação posta exige daqueles envolvidos uma ação de criação durante uma experiência que se mostra estética, num cenário de criação e experimento, produção de sentidos, livre para uma escrita pautada na possibilidade de, no devir. Proponho fazermos um exercício de pensar a palavra "experiência" neste contexto que se diz (ou é defendido) como inventivo:

A raiz indo-europeia da palavra 'experiência' é per, que foi interpretada como 'tentar', 'pôr à prova', 'arriscar', conotações que perduram na palavra 'perigo'. (...) Muitos dos significados secundários de per referem-se explicitamente aos motes 'atravessar um espaço', 'alcançar uma meta', 'ir para fora'”. (CARERI, 2013, versão Kindle - posição 526).

Neste sentido atribuído à experiência, o contracampo (ou o espaço off) da imagem assume uma importância quando se pensa no produto finalizado, no sentido de que a imagem e a experiência se fazem uma única coisa. Com as 
práticas videográficas tudo já se encontra na imagem, algo semelhante ao já debatido com o filme-ensaio nesta tese. Desta forma podemos pensar em "ensaios não escritos, ensaios em forma de enunciados audiovisuais" (MACHADO In DUBOIS, 2013, versão kindle - posição 116).

Retomando a proposta de trabalho com o vídeo para nos ocuparmos do caráter inventivo do cinema da ELC, a partir de uma abordagem estética visual: Dubois (2013, versão kindle - posição 868) defende que foram os artistas ligados à videoarte os que mais exploraram o vídeo e suas formas e modalidades e neste sentido enfatizo que é neste movimento que a ELC se baseia para trabalhar os projetos ligados à videoarte e às relações do cinema com a arte contemporânea. É do referencial formado por artistas da videoarte e da videodança, como uma forma de experimentação, de suas estéticas e modos de criação que saem as referências trabalhadas para uma aproximação dos alunos com o processo de criação.
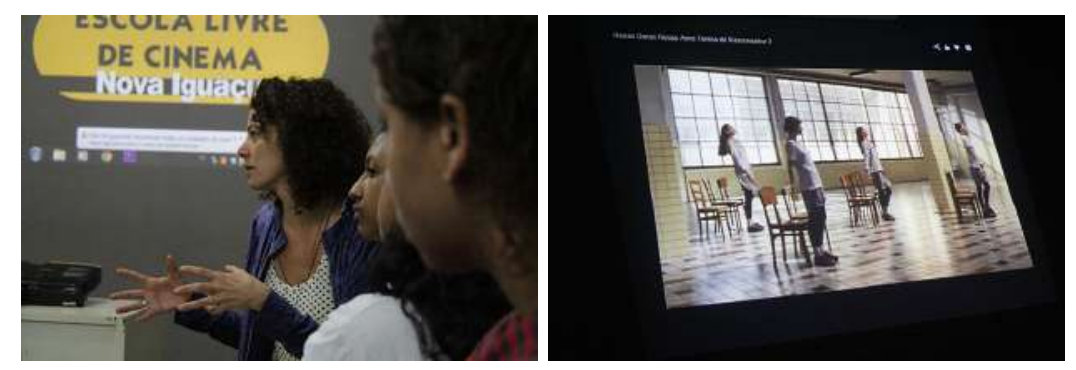

Imagem 46 - Aula 36 na ELC: Trabalhando a coreografia Re:Rosas, da coreógrafa Anne Tereza De Keersmaeker - Créditos: ELC

As imagens acima foram feitas durante a aula 36, quando os alunos foram apresentados a uma das referências para construção da videodança que seria feita a partir daquele mês, o projeto Re:Rosas. O trabalho da coreográfa belga Anne Teresa De Keersmaeker com a coreografia de Rosas, que foi criada há 30 anos e depois de um longo período nos palco a obra foi recriada para a tela pelo artista multimídia Peter Greenaway. O projeto serviu de referência para trabalhar, mais especificamente, uma interação entre os elementos da coreografia dos alunos da ELC e o bairro. Por meio da aproximação com este projeto e com suas múltiplas formas de desenvolvimento (coreografia para o palco, videodança e pelo trabalho de Greenaway) os alunos foram mobilizados a pensar as características de cada 
meio, assim como o caráter híbrido que a obra adquire quando trabalhada como uma videodança. Em Montão de Coisa podemos encontrar diversas referências ao trabalho de De Keersmaeker: o uso das cadeiras, a coreografia executada com o uso destas, a sincronização entre as marcações da trilha sonora e da coreografia. A ideia de sair pelas ruas de Austin com as cadeiras vermelhas da ELC nasceu daí.
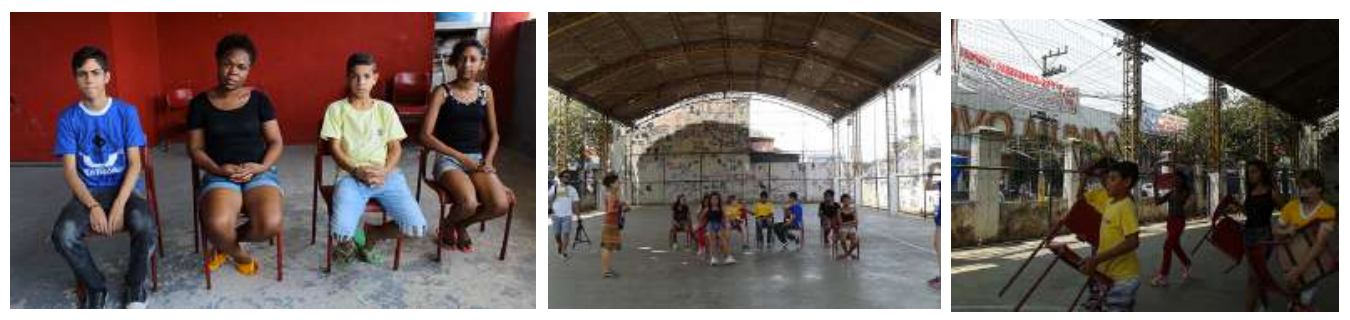

Imagem 47 - Bastidores de gravação de Montão de Coisa - coreografia com cadeiras - créditos: ELC

Quando me aproximo dos modos de criação da ELC fazendo uma leitura pautada pelas práticas videográficas não se trata de procurar o modo particular ou uma estética atribuída exclusivamente ao vídeo, mas de trabalhar na fronteira, no cruzamento de linguagens, considerando esta uma das características inerentes aos trabalhos da videodança. A exemplo disto, a construção da videodança, Montão de Coisa se aproximou mais da perspectiva da linguagem cinematográfica quando trabalhou a profundidade de campo para enfatizar o espaço e a importância do cenário, ou seja, dos caminhos de Austin e das imagens que marcam seu imaginário. Ao mesmo tempo, carrega consigo como referência do vídeo a composição de imagens que atua no sentido de fazer dialogar a coreografia, enfatizando o movimento e também o gesto dos alunos em cena. Esta escrita com a linguagem, através das práticas videográficas caracterizam o fazer da videodança, um gênero híbrido, que não é só dança, nem somente videoarte, mas a comunhão entre as duas linguagens. Na videodança "a câmera 'dirige' o olho do espectador das mãos às pernas, das pernas aos olhos etc., na ordem que mais lhe favoreça, e organiza os detalhes graças a uma montagem", como escreve Luiza Fagá Frame (2007).

A coreografia executada na passarela, no trem, na escola, na igreja, na praça, no comércio e o emaranhado de coisas percebidas e colecionadas pelos alunos e trabalhadas nesta composição de elementos, movimentos e cenário, nos faz pensar esta imagem como uma metonímia daquele território, por meio dos gestos 
borrados, de significados não necessariamente trabalhados como sinônimos, mas como elementos a serviço da inventividade de cada um, de cada gesto deslocado do seu local de origem ou inspiração.

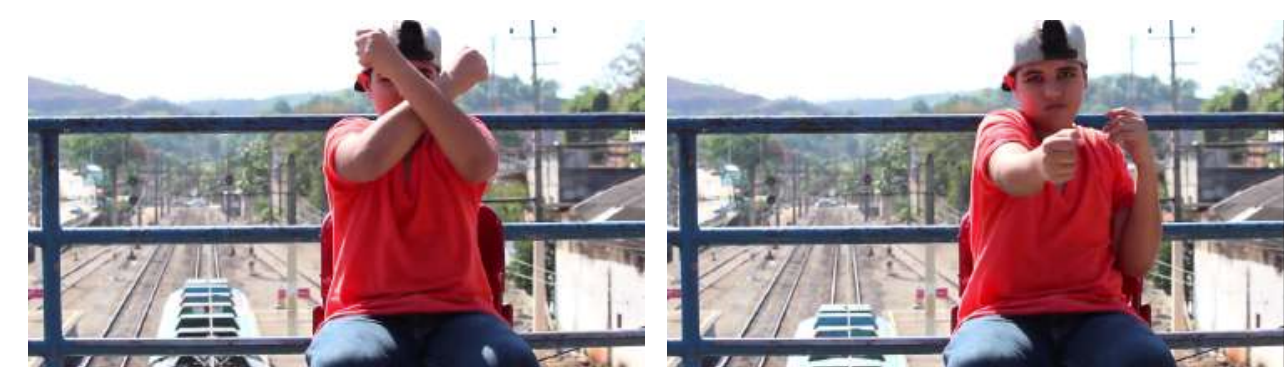

Imagem 48 - Frames da videodança Montão de Coisa: Gestos deslocados - créditos: ELC

Defendo que, desta forma, a distância inicial percebida (e vivenciada) pelos alunos durante o primeiro encontro com o cinema, vai se diluindo na mediada em que estes se envolvem na experiência, que encontram diante de si os paradoxos, os desafios, o homem da rua como o outro, um outro bairro. Desta forma, a produção de sentidos e a construção do espaço pelos mediadores e alunos atuam no sentido aguçar a criatividade e potencializar a invenção e, paulatinamente, este movimento faz com que os alunos se apropriem do que eles estão produzindo.

A composição de imagens e a montagem em Montão de Coisa atuam no sentido de enfatizar o diálogo entre a câmera e a coreografia, trabalhando enquadramento e fragmentação. Ao longo do processo de criação percebi que estes recursos de edição foram trabalhados durante o período de gravação das imagens para a videodança, o que leva entender que as imagens foram pensadas para se entrelaçarem num processo de edição sem muitos recursos de manipulação da imagem. O trabalho desenvolvido com o material bruto de Montão de Coisa foi sistematizado de forma que o editor pudesse trabalhar numa coreografia de imagens, arquitetando tempo e espaço. Esta relação com a figura do editor não foi pensada propriamente como uma função naquele processo, ela surgiu das necessidades apresentadas ali. As inventividades da ELC são ferramentas para resolver seus pequenos problemas em meio ao processo de criação. Desta forma, o trabalho de edição seguiu sendo feito pelo mediador responsável pelas aulas de linguagem, ou seja, o trabalho continuou sendo feito por alguém que participou de todo processo e não por alguém externo ao processo de negociação na construção da ideias e no nascimento das imagens. 
Todo material produzido foi reunido, revisto e selecionado pelos mediadores e alunos em sala. Juntos eles decidiram o que entrava ou não na composição final. Depois deste encontro mediadores e alunos só voltaram a se encontrar no dia da primeira exibição da videodança. O mesmo aconteceu comigo, não voltei à ELC depois do último encontro. Ao sair da escola todo material selecionado estava separado na pasta para edição e uma música estava sendo testada para servir como trilha sonora para Montão de Coisa. 


\subsection{A potencialidade do cinema}

Ao discutir a questão da expansão como elemento central, penso que estamos lidando com singularidades e subjetividades e, dessa forma, a experiência aqui trazida e problematizada nos instiga a pensar que é nessa relação, com esse cinema, que se torna possível, para os sujeitos nela envolvidos, inventar mundos, expandir espaços e relações. Não se trata somente de fazer ver, do ponto de vista metodológico. Tem a ver com a expansão do olhar, com a sensibilização, com o trabalho de percepção. Estas questões são trabalhadas na medida em que o cinema é colocado como mediador de relações. Isso me conduziu a uma aposta numa determinada potência do cinema, em sua capacidade de intensificar certas invenções de mundo, na possibilidade que ele possui de tornar comum o que não pertence aos sujeitos, a desnaturalização e a quebra do estranhamento.

Neste sentido se evidencia a dimensão simbólica do cinema, que pode atuar como máquina de pensamento, isto é, possibilitando o desenvolvimento de um pensar específico: com as imagens. O processo de criação envolve uma experiência perceptiva e como complementa Dubois (2013) sobre o cinema: "sua maquinaria é não só produtora de imagens como também geradora de afetos, e dotada de um fantástico poder sobre o imaginário" (versão kindle - posição 491).

A relação com os objetos técnicos é permeada por tensões, especialmente por se tratar de um contexto em que os sujeitos envolvidos geralmente não têm familiaridade com este tipo de equipamento. Fazendo uma leitura dos relatos durante o processo de criação dos alunos da ELC percebo que ao mesmo tempo em que a escola procura trabalhar a naturalização destes, não se tem como objetivo, em momento algum, a formação técnica dos alunos. Os mediadores atuam nesta relação no sentido de fazer com que os instrumentos sejam percebidos e manuseados sem um estranhamento, sem medo e sem a aura que “operar um equipamento cinematográfico" possa conter no senso comum e, ao mesmo tempo, procurando fazer com que isso não seja impeditivo para as gravações. Neste sentido a miniaturização das câmeras ajuda a mediar e a torná-lo mais convidativo. Este é o primeiro objetivo diante do encontro dos alunos com os equipamentos: fazer com que as máquinas, as câmeras e computador sejam postos a serviço do processo de nascimento das ideias. Essa relação com as máquinas é comentada por Dubois, conforme se lê a seguir: 
(...) as máquinas, enquanto instrumentos (technè), são intermediários que vêm se inserir entre o homem e o mundo no sistema de construção simbólica que é o princípio mesmo da representação. Se a imagem é uma relação entre o sujeito e o real, o jogo das máquinas figurativas, e sobretudo seu progressivo incremento, virá cada vez mais distender e separar os dois polos, como um jogo de filtros ou de telas se adicionando (DUBOIS, 2013, p. 422).

$\mathrm{O}$ cinema exerce um fascínio desde quando os irmãos Lumière exibiam suas imagens pelos cafés de Paris e suas máquinas atraíam curiosos movidos pelo desejo de entender como aquilo funcionava. Defendo que este brilho perdura até hoje, mesmo em meio à época do excesso de imagens, em que todos podem lotar seus cartões de memória ou celular fazendo vídeos e pequenas histórias para serem publicadas em uma rede social. É no encontro com os elementos que constituem o cinema, com a tensão que nasce dentro do processo de criação, com os experimentos do fazer que este brilho volta a ser manifesto. Afinal, a ação de criar é uma necessidade para o homem. É no manuseio dos elementos essenciais ao cinema: a linguagem e a experiência de conhecer o cinema como "coisa viva e como um laboratório de emoção", como escreveu Lischi (1997, p 7) ao comentar a experiência da Escola de videodocumentação I Cammelli ${ }^{35}$, que os alunos da ELC são transformados e transformam essa experiência estética também em uma experiência de alteridade.

Na prática da ELC a cidade se torna um espaço de criação, a partir de uma nova relação estabelecida. Por vezes, os alunos se permitem descobrir "o outro", as singularidades do local, de modo que, é durante as caminhadas, que Austin deixa de ser o lugar "chato, sem nada para fazer e ver" (ideia inicial trazida por grande parte dos alunos), é lá que os alunos descobrem o outro, as singularidades do local, que é a parte mais comum do cotidiano dos que se encontram nas salas da ELC. A ação de caminhar e fazer pequenos percursos pelo bairro assume aqui uma importância no processo de desnaturalização e de produção de sentidos dos alunos com o bairro, onde aquele espaço torna-se elemento dentro do processo de criação. As ideias que estruturam este projeto se fazem ali, nascem do encontro, quando alunos e mediadores tomam esta experiência no território também como ferramenta de criação e experimentação.

\footnotetext{
${ }^{35} \mathrm{Na}$ Itália essa escola é conhecida como "Scuola video di documentazione sociale I Cammelli”.
} 
As práticas desenvolvidas pelos sujeitos, a produção de sentidos e as subjetividades negociadas, transformam lugares em espaços de criatividade. Isso significa ter, em Austin, um espaço para desenvolver as ações de criação. Ao sair da escola para mais um dia de gravação ou para catar imagens para uma coleção, os alunos e mediadores são alimentados pelos paradoxos das ruas, numa experiência estética que ajuda a atribuir outros significados para os elementos cotidianos. O percurso constrói um mapa, traça um caminho, enquanto desenvolve ações estéticas. Desta forma, eles exploram os espaços e por vezes se fazem guias destes, especialmente quando precisam explicar alguma singularidade que só um “praticante ordinário" (CERTEAU, 1994), seu habitante no cotidiano saberia explicar: o que nem os mapas da cidade registram. Lembro quando resolvi pedir uma informação sobre uma determinada praça a um pequeno grupo de alunos que estava comigo na sala. Depois da pergunta resolvi abrir o mapa para que eles me explicassem, mas um aluno me levou para a janela e, fazendo o percurso com sua mão, me explicou sobre o caminho que levava à praça que eu queria conhecer.

Por meio da experiência com as caminhadas e deslocamentos ${ }^{36}$ ao longo do projeto e os vários desafios aceitos (refiro-me aos desafios criados pelos dispositivos e desenvolvidos durante as aulas) se fez também o encontro com o outro, que se refere aos outros daquele território, os vários outros da cidade. Neste caso são, sobretudo os moradores de Austin, as pessoas que fazem parte daquele bairro. Sobre este tipo de encontro com a alteridade na ação de caminhar Jacques (2013) comenta:

(...) o caminhar é um caminho para esse encontro, quase sempre dissensual e conflituoso. Mas, como sabemos, os dissensos e conflitos urbanos não só são legítimos e necessários para a constituição da esfera pública e também dos espaços públicos, mas seria exatamente da permanência dessa tensão entre as diferenças não idealizadas nem pacificadas que dependeria a construção de uma cidade menos espetacular e mais lúdica e experimental (JACQUES ${ }^{37}, 2013$, versão kindle - posição 136).

\footnotetext{
${ }^{36}$ É recorrente nesta tese o uso das palavras "caminhadas" e "deslocamento". Com caminhadas me refiro a um exercício específico que foi feito na ELC, com a proposta de um percurso pelo bairro. Com deslocamento me refiro a qualquer ação de deslocar-se pela cidade durante o processo de criação de Montão de Coisa.

37 Esta referência de JACQUES, Paola (2013) abre o livro do pesquisador italiano Francesco Careri.
} 
Este processo comentado por Jacques (2013) e que uso aqui para tratar do viés da experiência da ELC que toca diretamente a visão de cidade que paulatinamente vai sendo construída através desta experiência com o cinema, atua nas fronteiras entre o que tomamos com lugar e espaço, é justamente esta mistura e esta tensão que mantém vivos os diferentes usos deste espaço e faz com que sejam produzidas novas narrativas daquele território.

Observando as tensões e relações que se evidenciam durante o processo de criação e as ações que envolvem o nascimento das ideias, percebemos que o sujeito se põe como ser fazedor, como aquele que dá forma a algo novo. Neste sentido, ao criar a partir de uma relação com seu espaço, ele relaciona, ordena, configura e atribui significados a este, colocando-se numa postura autoral. Trago agora um dos casos que aconteceu durante o convívio com o estudantes de Austin e que me fez refletir sobre este ser fazedor, foi um episódio que aparece no catálogo comemorativo de 10 anos da ELC: a escola promoveu um passeio com os alunos para o MAM - Museu de Arte Moderna do Rio Janeiro. Todos estavam reunidos quando um dos monitores do Museu mencionou em voz alta que aquele grupo era formado por jovens de Austin. Na mesma hora um dos alunos pediu: “Tio, não fala que somos de Austin, as pessoas podem pensar alguma coisa...". Ele se referia à imagem negativa e aos estereótipos que a região da Baixada Fluminense do Rio de Janeiro carrega. Um dos mediadores da ELC relatou que naquele mesmo dia houve, durante a visita, uma atividade com uma pipa, que ninguém conseguia empinar. Ao entrarem na dinâmica da atividade, foi o grupo de Austin o primeiro a conseguir colocar a pipa no alto. Naquele momento surgiu o sentimento de orgulho pelo feito, de se sentir capaz. O mesmo acontecia quando durante as aulas eles precisavam escolher algum ponto do bairro para explorar e ali usar a câmera, captar imagens e fazer imagens: inicialmente havia o silêncio, mas depois que a atividade começava a ser desenvolvida e especialmente quando as imagens eram projetadas em sala para serem analisadas, eles assumiam outra postura.

Diante das situações e principalmente das ações necessárias para "revolver" os problemas de criação que surgiam, os alunos assumiam a postura de um sujeito fazedor, relacionando os eventos que ali se desenvolviam e tomando para si aquelas imagens, assumindo-as. Nesse sentido, escrevendo sobre os processos criação e sobre o homem fazedor envolvido nestes, Ostrower (2004) 
defende que, "relacionando os eventos, ele [o sujeito] os configura em sua experiência do viver e lhes dá um significado. Nas perguntas que o homem faz ou nas soluções que encontra, ao agir, ao imaginar, ao sonhar, sempre o homem relaciona e forma" (p. 9). A potencialidade que emerge da relação dos alunos com o processo de criação, numa busca por significados e ordenações converte-se em necessidade. Na necessidade que todo sujeito tem de formar, criar.

Quando no capítulo 2 descrevi Austin, expus um bairro percebido por mim. No entanto, ao longo do texto ele surgiu percebido e narrado pelos alunos. Esta forma de narrar ou representar é uma escolha feita pelos alunos, os elementos que se evidenciam e as imagens produzidas são fruto das relações estabelecidas entre eles e o mundo e da troca subjetiva que o cinema permite. Sendo assim, é totalmente possível que aquele espaço, que pra mim se apresentava polifônico, movimentado, colorido e quente, fosse o espaço da praça silenciosa, do cochilo à sombra da árvore para esperar a hora passar, como apresentado no vídeo feito por um dos alunos em sala. A primeira imagem descrita foi o meu mundo vivido em Austin, a segunda é o mundo que ele queria representar naquela hora, com sua subjetividade.

Ao final deste capítulo onde as proposições teóricas, metodológicas e empíricas transitaram por entre tensões como o processo de criação, alteridade, encorajamento estético e inventividade, arrisco afirmar que a potência do cinema experienciado pelos alunos e mediadores da ELC está no fato de que ele se faz catalizador destas relações, agindo num sentido de estimular, desafiar, incentivar os atos de criação dos alunos em meio à experiência estética vivida com o processo de criação da videodança Montão de Coisa (e disso decorre a escolha de uma leitura pelo viés do cinema expandido). 


\section{A título de conclusão}

A coleção empírica feita para este texto-tese: as observações e os registros delas decorrentes se transformaram num acervo diversificado, que foi produzido e organizado em cadernos de notas, em fotografias, gravações e no blog. Tal acervo permitiu problematizar o processo de criação na ELC.

Apostando que uma leitura possível fosse a descrição dos dispositivos e dos exercícios, tencionei, a partir dela, identificar elementos que pudessem compor a caracterização do processo criativo numa perspectiva diferenciada, isto é, construída a partir do viés da pesquisa acadêmica. Com isso, argumento que o cinema produzido na ELC é catalizador de muitos encontros por meio de seu processo criativo: consigo, com o outro, com o lugar, com realidades distantes e próximas, com a técnica e com tecnologias, com o próprio cinema.

Com este texto-pesquisa sobre cinema, num Programa de Pós Graduação em Comunicação, quis contribuir com uma leitura possível, pois falar de processos de criação é falar sobre o que, às vezes, não aparece na obra pronta. Há muitas coisas no processo de criação que ficam subsumidas pelo caminho. Esses bastidores são repletos de negociações e tensões e tratá-los pelo viés da experiência foi a escolha desta pesquisadora. $\mathrm{O}$ intuito foi sempre o de percorrer caminhos caros a mim e nos quais apostei como possíveis em forma e densidade para a construção desta tese: criatividade e inventividade.

Neste ponto da trajetória identifico possibilidades outras de abordagem e desdobramentos possíveis. No entanto, o texto aqui apresentado seria outro caso as escolhas assim tivessem sido. Desse modo, faço apenas apontamentos sobre algumas discussões que este tema tem me apresentado como potentes, mas que não compuseram o roteiro desta pesquisa. Arrisco-me, então, a explicitar que seria interessante uma abordagem pautada na ideia do sensível e da emoção, pois possibilitaria discutir elementos próximos ao processo criativo. Falo de tratar da emoção - num sentido mais próximo à empatia - e do envolvimento do sujeito que pensa com as imagens que encontra no mundo e que, a partir delas, pensa, criando outras imagens e produzindo novos sentidos para possíveis leituras de mundo. Desta forma, a questão da emoção tornar-se-ia produtiva para pensar os processos de naturalização dos aparatos técnicos do cinema e se expandiria potencialmente 
na discussão acerca das relações com o ato criador. Do mesmo modo, pontuo outro aspecto que me tem chamado a atenção e despertado certa curiosidade epistemológica: a relação entre a cultura jovem e a forma como se relacionam com a cena cultural no que diz respeito ao território e aos usos das novas tecnologias. Para investigar não apenas como consomem produtos culturais, mas como esse consumo alimenta um repertório individual e coletivo, cujo processo de apropriação e ressignificação, influencia diretamente o ato criativo. Por fim, não posso deixar de trazer neste momento o fato de que nos últimos dias de escrita desta tese, travei contato com os escritos de Catherine Russel (1999), cujo trabalho a respeito da análise etnográfica de filmes experimentais abordando ao mesmo tempo, aspectos estéticos e etnográficos, chamou-me a atenção pelo rigor, pelo percurso de pesquisa e por sugerir, em minha leitura ainda insipiente, um potencial dialógico com o trabalho por mim realizado. Contudo, essa aproximação incipiente e ainda superficial não me permitiu estabelecer um diálogo com a autora, mas sugere que este tende a ser profícuo.

Cabe dizer, neste ponto, que não há “fim” possível. O que há, entendo, são proposições contingenciais. Certa de que não cheguei (e que possivelmente jamais chegarei) ao final dessa discussão, estanco por aqui o texto como quem fez um mergulho e trouxe consigo pequenos achados. O exercício da escrita, tão intenso e laborioso foi, sem dúvida, meu maior desafio neste período. O doutorado é mais do que a tese, mas esta dá-lhe um caráter definitivo; sentenciado, fixado nas palavras. E, sobre palavras, é senso comum afirmar que quando essas nos faltam, recorremos com mais competência às imagens. Confesso que penso melhor com as imagens. Mas as palavras são necessárias e aqui estão dispostas como num quebra-cabeças que foi montado por mim com o objetivo de que fosse possível, ao cabo do empreendimento, reconhecer nele a imagem.

Tomo as palavras de Larrosa (2007) sobre a escrita e como ela nos modifica:

Escrever (e ler) é como submergir num abismo em que acreditamos ter descoberto objetos maravilhosos. Quando voltamos à superfície, só trazemos pedras comuns e pedaços de vidro e algo assim como uma inquietude nova no olhar. $\mathrm{O}$ escrito (e o lido) não é senão um traço visível e sempre decepcionante de uma aventura que, enfim, se revelou impossível. E, no entanto, voltamos transformados. Nossos olhos aprenderam uma nova insatisfação e não se acostumam mais à falta de brilho e de mistério daquilo que se nos oferece à 
luz do dia. E algo em nosso peito nos diz que, na profundidade, ainda resplandece, imutável e desconhecido, o tesouro (p. 156).

Desejo que este texto tenha sido capaz de apresentar o percurso dessa aventura acadêmica, em uma discussão que procurou seus elementos no processo criativo que envolve o nascimento da imagem cinematográfica. 


\section{Referências bibliográficas}

AUGÉ, Marc. Un Etnologo al Bistrot. Milano: Raffaello Cortina Editore, 2015.

BARBOSA, Maria Carmen Silveira; SANTOS, Maria Angélica dos. Escritos de alfabetização audiovisual. Porto Alegre: Libretos, 2014.

BAUER, Martin W.; GASKELL, George (Org.). Pesquisa qualitativa com texto, imagem e som: um manual prático. Petrópolis, RJ: Vozes, 2008.

BELLOUR, Raymond. Entre imagens: fotos, cinema, vídeo. Campinas: Papirus, 1997.

BERGALA, Alain. A hipótese-cinema: pequeno tratado de transmissão do cinema dentro e fora da escola. Rio de Janeiro: Booklink; INEAD-LISEPE/UFRJ, 2008.

BERTOZZI, Marco. Imparare facendo - Intrevista a Mario Brenta. In: ERMANNO OLMI: Il cinema, i film, la televisione, la scuola. APRÀ, Adriano (cura). Venezia: Marsilio Editori S.P.A, 2003. p. 315-323.

BRANDÃO, Zaia. Pesquisa em Educação: conversas com pós-graduandos. Rio de Janeiro: Ed. PUC-Rio; São Paulo: Loyola, 2002.

BRASIL, André. Ensaios de uma imagem só. In: Ensaios no Real - o documentário brasileiro hoje. MIGLIORIN, Cezar (org.). Rio de Janeiro: Beco do Azougue, 2010. p. 169-179.

BRUM, Leonel. Videodança: uma arte do devir. In: Dança em foco: ensaios contemporâneos de videodança. CALDAS, Paulo (org). Rio de Janeiro: Aeroplano, 2012. p. 74- 113.

CARERI, Francesco. Walkscapes: o caminhar como prática estética. São Paulo: Editora G. Gili, 2013 [ $1^{\mathrm{a}}$ versão eletrônica - versão kindle].

CRUZ, Roberto Moreira S. Experiências pioneiras em cinema expandido. Revista Z Cultural. Ano VIII, n. ${ }^{\circ}$ 01. 2012. Disponível em: http://revistazcultural.pacc.ufrj.br/experiencias-pioneiras-em-cinema-expandidode-roberto-moreira-2/. Acesso em 02 de dezembro de 2014.

CERBINO, Beatriz; MEDONÇA, Leandro. Coreografia, corpo e vídeo: apontamentos para uma discussão. In: Dança em foco: ensaios contemporâneos de videodança. CALDAS, Paulo (org). Rio de Janeiro: Aeroplano, 2012. p. 150166.

DAVID, Bruni. A scuola di cinema: la formazione nelle professioni dell'audiovisivo. Udine: Forum, 2012.

DE CERTEAU, Michel. A invenção do cotidiano: artes de fazer. $3^{\mathrm{a}}$ ed. Petrópolis: Vozes, 1998. 
DELEUZE, Gilles. O ato de criação. Trad. José Marcos Macedo. In: Folha de São Paulo, Caderno Mais!, 27 de junho de 1999.

DUARTE, Rosália; GONÇALVES, Beatriz Moreira de Azevedo Porto. Relações entre Cinema e Educação na esfera pública brasileira. In: BARBOSA, Maria Carmen Silveira; SANTOS, Maria Angélica dos. Escritos de alfabetização audiovisual. Porto Alegre: Libretos, 2014, p. 35-46.

DUBOIS, Philippe. Cinema, vídeo, Godard. São Paulo: Cosac Naify, 2013. [1 ${ }^{\text {a }}$ edição eletrônica - versão kindle].

DUCHAMP, Marcel. O ato criador. 1965. In: BATTCOCK, Gregory. A nova arte. 2 ed. São Paulo: Editora Perspectiva, 1986.

FONSECA, Claudia. Quando cada caso NÃO é um caso: pesquisa etnográfica e educação. Revista Brasileira de Educação, Rio de Janeiro, ANPEd, n. 10, p. 5878, jan./abr. 1999.

FRAME, Luiza Fagá. Câmera que dança: o casamento entre vídeo e coreografia. In: Revista Continuum Itaú Cultural. São Paulo: Itaú Cultural, 2007. Disponível em: https://issuu.com/itaucultural/docs/revista-continuum-2. Último acesso em: 14 de março de 2017.

GEERTZ, Clifford. A interpretação das Culturas. 1. ed. [reimpr]. Rio de Janeiro: LTC, 2015.

GOHN, Maria da Glória Marcondes. Educação não formal e o educador social [livro eletrônico] : atuação no desenvolvimento de projetos sociais. 1. ed. São Paulo : Cortez, 2013. (Coleções questões da nossa época ; v. 1) [1 $1^{\mathrm{a}}$ edição eletrônica - versão kindle]

GREINER, Christine. O corpo: pistas para estudos indisciplinares. São Paulo: Annablume, 2013. [1 ${ }^{\text {a }}$ edição eletrônica - versão kindle].

HERSCHMANN, Micael; FERNANDES, Cíntia Sanmartin. Música nas ruas do Rio de Janeiro [edição eletrônica] - São Paulo: Intercom, 2014. 272.

JACQUES, Paola Berenstein. Elogio aos errantes. Salvador: EDUFBA, 2012.

JACOB, Cesar Romero; HEES, Dora Rodrigues; WANIEZ, Philippe. Atlas das condições de vida na região metropolitana do Rio de Janeiro [recurso eletrônico]. - Rio de Janeiro: Ed. PUC-Rio, 2014.

KATZ, Helena; GREINER, Christine. Por uma teoria do corpomídia. In: GREINER, Christine. O corpo: pistas para estudos indisciplinares. São Paulo: Annablume, 2013. [ $1^{\mathrm{a}}$ edição eletrônica - versão kindle].

LARROSA, Jorge. Tremores: escritos sobre experiência. $1^{\text {a }}$ ed. Belo Horizonte: Autêntica Editora, 2014. 
Experiência e alteridade em educação. Revista Reflexão e Ação, Santa Cruz do Sul, v.19, n. ${ }^{\circ}$ 2, p.04-27, jul/dez. 2011.

Literatura, experiência e formação. In: COSTA, M. V. (org). Caminhos investigativos I: novos olhares na pesquisa em educação. 3. ${ }^{a}$ ed. Rio de Janeiro: Lamparina Editora, 2007. P. 129-156.

Notas sobre a experiência e o saber de experiência. Revista Brasileira de Educação, n. 19, 2002, p. 20-28.

LATOUR, Bruno. Reagregando o social - uma introdução à teoria Ator-Rede. Bauru: Edusc, 2012

LINS, Consuelo e MESQUITA, Claudia. Filmar o real: sobre o documentário brasileiro contemporâneo. Rio de Janeiro: Jorge Zahar, 2008.

LINS, Consuelo. $O$ ensaio no documentário e a questão da narração em off. In: Ades, E.; Bragança, G; Cardoso, J; Bouillet, R.. (Org.). O Som no cinema. Rio de Janeiro: Tela Brasilis/Caixa Cultural, 2008, v. , p. 131-144.

LISCHI, Sandra. Il linguaggio del video. Roma: Carocci editore, 2007.

LISCHI, Sandra; PIAZZA, Pucci (org). A Occhio Nudo: la scuola video di documentazione sociale I Cammelli. Festival Internazionale Cinema Giovani. Torino: Lindau s.r.1., 1997.

MACHADO, Arlindo. O cinema e a condição pós-midiática. Cinema sim: narrativas e projeções: ensaios e reflexões / organização Kátia Maciel. São Paulo: Itaú Cultural, 2008.

MARCIEL, Katia (org.) Cinema sim: narrativas e projeções: ensaios e reflexões. São Paulo: Itaú Cultural, 2008.

MARTÍN-BARBERO, Jesús. Ofício de cartógrafo: travessias latinoamericanas da comunicação na cultura. São Paulo: Loyola, 2004. 478 p. ( Comunicação contemporânea

MIGLIORIN, Cezar. Inevitavelmente cinema: educação, política e mafuá. $1 .^{\mathrm{a}}$ ed. Rio de Janeiro: Beco do Azougue, 2015.

- O cinema, a escola, o estudante e a invenção de mundos. In: BARBOSA, Maria Carmen Silveira; SANTOS, Maria Angélica dos. Escritos de alfabetização audiovisual. Porto Alegre: Libretos, 2014a. p. 99-107.

Deixem essas crianças em paz: o Mafuá e o cinema na escola. In: BARBOSA, Maria Carmen Silveira; SANTOS, Maria Angélica dos. 
Escritos de alfabetização audiovisual. Porto Alegre: Libretos, 2014b. p. 99-107.

- Um mundo comum com Miguel Couto. Catálogo comemorativo de 5 anos da Escola Livre de Cinema de Nova Iguaçu. Rio de Janeiro: Escola Livre de Cinema de Nova Iguaçu, 2011.

Ensaios no real. Rio de Janeiro: Beco do Azougue, 2010.

MIGLIORIN, C. ; PIPANO, Isaac ; VIEIRA JR., L. G. ; NANCHERY, Clarissa ; GUERREIRO, Alexandre ; BENEVIDES, F. . Inventar com a Diferença cinema e direitos humanos. $1^{\text {a }}$. ed. Niterói: Editora da UFF, 2014. 104p.

MONTAIGNE, Michel de. Os ensaios: uma seleção. São Paulo: Companhia das Letras, 2010.

PEREIRA, Miguel. Filme-ensaio ou o cinema da experiência. XXIII Encontro Anual da Compós. Universidade Federal do Pará. Pará: Compós, 2014.

RANCIÈRE, Jacques. O espectador emancipado. São Paulo: Editora WMF Martins Fontes, 2012.

. A partilha do sensível: estética e política. São Paulo: EXO experimental org,; Editora 34, 2009.

. O mestre ignorante - cinco lições sobre a emancipação intelectual. 2ed. Belo Horizonte: Autêntica, 2004.

Editora 34, 1996

. O desentendimento - política e filosofia. São Paulo,

OSTROWER, Fayga. Criatividade e Processos de Criação. Rio de Janeiro: Editora Vozes, 2004.

PIEROTTI, Federico. Experiments and Theories in Emotions, Technology and Design. In: Emotions, Technology, and Design. TETTEGAH, Sharon; NOBLEP, Safiya. 3-18. London: Elsevier Inc., 2016.

PIPANO, I. 12 etapas e uma lição para se fazer um filme-carta (em tempos de whatsaap). In: MOSTRA FILMES-CARTA POR UMA ESTÉTICA DO ENCONTRO, Catálogo, MEDEIROS, Rúbia Mércia Oliveira (org.), Rio de Janeiro: Caixa Cultural, 2013. p. 28-29.

RUSSELL, Catherine. Experimental Ethnography: The work of film in the age of video. London: Duke University Press, 1999.

SALLES, Cecília Almeida. Crítica genética: fundamentos dos estudos genéticos sobre o processo de criação artística. $3 .^{a}$ ed. revista. São Paulo: EDUC, 2008.

SERRES, Michel. Polegarzinha. Rio de Janeiro: Bertrand Brasil, 2013.

SONTAG, Susan. On Photography. 5th electr. ed. New York: Rosetta Books, 
2005. pp.42-43.

SPANGHERO, Maíra. A dança dos encéfalos acesos / Apresentação Helena Katz; texto Leda Pereira. — São Paulo: Itaú Cultural, 2003. 141 p. : fotos color. (Rumos Itaú Cultural Transmídia).

STAJANO, Corrado. La mia esperienza con Olmi. In: ERMANNO OLMI: Il cinema, i film, la televisione, la scuola. APRÀ, Adriano (cura). Venezia: Marsilio Editori S.P.A, 2003. p. 306-311.

VENTURINI, Tommaso. Diving in Magma: How to Explore Controversies with Actor-Network Theory in Public Understanding of Science, 20:4 mai 2010. Disponível em: http://www.medialab.sciences-po.fr/publications/diving-inmagma-how-to-explore-controversies-with-actor-network-theory/. Acesso em 08/09/2016.

TEIXEIRA, Francisco Elinaldo. Cinema "não narrativos": Experimental e documentário - passagens. $1^{\mathrm{a}}$ ed. São Paulo: Alameda, 2012.

TRAVANCAS, Isabel. Fazendo etnografia no mundo da comunicação. In: DUARTE, Jorge; BARROS, Antonio (org.). Métodos e técnicas de pesquisa em comunicação. 2. ed. São Paulo: Atlas, 2009. p.98-109.

Teses e dissertações:

ALVARENGA, Clarisse Maria Castro de. Vídeo e experimentação social: um estudo sobre o video comunitário contemporâneo no Brasil, 2014. Dissertação (Mestrado). Instituto de Artes, Universidade Estadual de Campinas. Campinas, SP: [s.n.], 2004.

BRANDÃO, Ronaldo Macedo. Fronteiras, Corpos e Deslocamentos: Poéticas Visuais e Espaços Limites. 2015. 276f. Tese (Doutorado) - Faculdade de Belas Artes da Universidade do Porto. Porto, 2015.

CHAVEZ, Marcio Blanco. A questão da autoria na produção de filmes em duas oficinas de formação audiovisual. 2014. 101 f. Dissertação (Mestrado) em Comunicação, Faculdade de Comunicação Social, Universidade do Estado do Rio de Janeiro, Rio de Janeiro, 2014.

DASSOLER, Elisa Rodrigues. Coletivo arte na periferia: por uma outra dimensãoo territorial das artes visuais. 2011. 198f. Dissertação (Mestrado) Departamento de Artes Visuais do CEART/UDESC, Universidade do Estado de Santa Catarina, 2011.

FRANCISCO, Monica da Silva. A Escola Livre de Cinema de Nova Iguaçu: educação, cultura e política para jovens da Baixada Fluminense. 2015. $73 \mathrm{f}$. Dissertação (mestrado) - Programa de Pós-Graduação em Educação, Contextos Contemporâneos e Demandas Populares, Universidade Federal Rural Do Rio De Janeiro, 2015. 
FREIRE, Teresa Cristina Fazolo; Novas telas, novos olhares: audiovisual e inclusão subjetiva na Escola Livre de Cinema de Nova Iguaçu. 2012. $154 \mathrm{f}$. Dissertação (Mestrado) - Departamento de Comunicação Social, Pontifícia Universidade Católica do Rio de Janeiro, 2012.

MIGLIORIN, Cezar Avila. Eu sou aquele que está de saída: dispositivo, experiência e biopolítica no documentário contemporâneo. Rio de Janeiro, 2008. 279 p. Tese (Doutorado em Comunicação) - Universidade Federal do Rio de Janeiro, CFCH/ECO, 2008.

MORAES, Lilian Saback de Sá. A autorrepresentação das favelas: a criação de mundos possíveis por sujeitos heterotópicos. 2010. 93f. Dissertação (Mestrado) - Departamento de Comunicação Social, Pontifícia Universidade Católica do Rio de Janeiro, Rio de Janeiro, 2010.

SILVA, Gustavo Souza da. Pontos de vista em documentários de periferia: estética, cotidiano e política. 2011. Tese (Doutorado) - Escola de Comunicações e Artes / Universidade de São Paulo. São Paulo, 2011.

Toledo, Moira. Educação Audiovisual Popular no Brasil - Panorama, 19902009/ Moira Toledo; São Paulo, 2010 361f. 2 v. Tese (Doutorado) - Universidade de São Paulo, 2010.

ZANETTI, Daiela. O cinema da periferia: narrativas do cotidiano, visibilidade e reconhecimento social. 2010. 319f. Tese (Doutorado) Departamento de Comunicação e Cultura Contemporâneas, Universidade Federal da Bahia, Bahia, 2010. 


\section{Anexo 1}

Tabela com resumo de atividades dia a dia $1^{\mathrm{a}}$ semestre $2014 \mid$ ELC

\begin{tabular}{|c|c|c|c|}
\hline Data & $\mathbf{N}^{0}$ & Aula & Atividade \\
\hline $12 / 02$ & 1 & Linguagem & $\begin{array}{l}\text { Início das aulas } \\
\text { Alguns vídeos - repertório } \\
\text { Atividade: abecedário }\end{array}$ \\
\hline $14 / 02$ & 2 & Linguagem & $\begin{array}{l}\text { Exercício de linguagem com a câmera } \\
\text { Elementos da fotografia: ISO, obturador e diafragma }\end{array}$ \\
\hline $19 / 02$ & 3 & Linguagem & $\begin{array}{l}\text { Repertório - coletânea Irmãos Lumière } \\
\text { Linguagem: zoom, foco etc } \\
\text { Exercício Lumière } \\
\text { Dispositivo: } \\
\text { Sair pela rua para fazer o Minuto Lumière }\end{array}$ \\
\hline $21 / 02$ & 4 & Linguagem & $\begin{array}{l}\text { Análise do Minuto Lumière } \\
\text { Refazer o Minuto Lumière } \\
\text { Repertório }\end{array}$ \\
\hline $24 / 02$ & 5 & Linguagem & $\begin{array}{l}\text { Abertura da videoinstalação \#circulando } \\
\text { Na Lapa, todos os alunos foram convidados }\end{array}$ \\
\hline $26 / 02$ & 6 & Linguagem & $\begin{array}{l}\text { Linguagem (velocidade da luz) } \\
\text { Exercício de lightpaint }\end{array}$ \\
\hline $28 / 02$ & 7 & Projeção & $\begin{array}{l}\text { Repertório - exibição da Batalha do Passinho para todas as } \\
\text { turmas }\end{array}$ \\
\hline $12 / 03$ & 8 & $\begin{array}{l}\text { Cinema, } \\
\text { corpo e dança }\end{array}$ & $\begin{array}{l}1^{\mathrm{a}} \text { aula - "cinema, corpo e dança" } \\
\text { O corpo no cinema e a relação com a dança } \\
\quad \text { - como o corpo é filmado (cinema de origem e } \\
\quad \text { contemporâneo) } \\
\text { Repertório }\end{array}$ \\
\hline $14 / 03$ & 9 & Linguagem & $\begin{array}{l}\text { Linguagem - conceito de raccord } \\
\text { Exercício de filmagem: } 3 \text { planos diferentes para uma ação } \\
\text { Repertório } \\
\text { Dispositivo: } \\
3 \text { planos para uma mesma ação }\end{array}$ \\
\hline $19 / 03$ & 10 & $\begin{array}{l}\text { Cinema, } \\
\text { corpo e dança }\end{array}$ & $\begin{array}{l}\text { Aula de "cinema, corpo e dança" } \\
\text { Assistir vídeo dos colegas (produção dos alunos) } \\
\quad \text { - quem esta olhando o que? Onde esta o olho? } \\
\quad \text { Exercício: } 3 \text { círculos numa folha de papel } \\
\text { Repertório } \\
\text { Dispositivo: } \\
\text { Enquadramento - } 3 \text { círculos numa folha de papel }\end{array}$ \\
\hline $21 / 03$ & 11 & Linguagem & $\begin{array}{l}\text { Aula de linguagem: } \\
\text { Efeito Kuleshov } \\
\text { Estratégias narrativas de montagem: raccord e jamp cut } \\
\text { Roteiro* }\end{array}$ \\
\hline
\end{tabular}




\begin{tabular}{|c|c|c|c|}
\hline & & & Repertório \\
\hline $26 / 03$ & 12 & $\begin{array}{l}\text { Cinema, } \\
\text { corpo e dança }\end{array}$ & $\begin{array}{l}\text { Aula de "cinema, corpo e dança" } \\
\quad-\quad \text { O que olhamos e como. Micro e macro } \\
\text { Repertório }\end{array}$ \\
\hline $28 / 03$ & 13 & Linguagem & $\begin{array}{l}\text { Aula de linguagem } \\
\text { Gravação do roteiro (revezamento entre atuação e } \\
\text { cinegrafista) }\end{array}$ \\
\hline $02 / 04$ & 14 & $\begin{array}{l}\text { Cinema, } \\
\text { corpo e dança }\end{array}$ & $\begin{array}{l}\text { Aula de "cinema, corpo e dança" } \\
-\quad \text { Literalidade e metáfora como suportes narrativos } \\
\text { - Pensar um percurso filmado de forma não literal e } \\
\quad \text { linear } \\
\text { Repertório }\end{array}$ \\
\hline $04 / 04$ & 15 & Linguagem & $\begin{array}{l}\text { Aula de linguagem } \\
\text { Edição dos vídeos feitos na aula passada usando o Adobe } \\
\text { Premieire } \\
5 \text { planos e uma ação, os vídeos foram trabalhados pensando o } \\
\text { raccord e o jump cut. } \\
\text { Projeção do vídeo editado } \\
\text { Dispositivo: } \\
5 \text { planos e uma ação (pensando o raccord e o jump cut). }\end{array}$ \\
\hline $09 / 04$ & 16 & $\begin{array}{l}\text { Cinema, } \\
\text { corpo e dança }\end{array}$ & $\begin{array}{l}\text { Aula de "cinema, corpo e dança" } \\
\text { A caminhada silenciosa (observando o caminho: movimento, } \\
\text { subjetividade e propriocepção) } \\
\text { Desenho do corpo com a caminhada descrita em palavras } \\
\text { chave } \\
\text { Dispositivo: } \\
\text { A caminhada silenciosa }\end{array}$ \\
\hline $11 / 04$ & 17 & Linguagem & $\begin{array}{l}\text { Aula de linguagem } \\
\quad \text { - As intenções de um diretor de cinema } \\
\text { Trabalha elementos da linguagem (revisão) e gêneros } \\
\text { cinematográficos } \\
\text { Movimento/posicionamento de câmera e ritmo fílmico } \\
\text { Repertório } \\
\text { Uso de material de apoio para aula (do projeto inventar com a } \\
\text { diferença) }\end{array}$ \\
\hline $16 / 04$ & 18 & $\begin{array}{l}\text { Cinema, } \\
\text { corpo e dança }\end{array}$ & $\begin{array}{l}\text { Aula de "cinema, corpo e dança" } \\
\text { - Território em movimento: eu com o mundo, percepção, } \\
\text { propriocepção } \\
\text { Apresentação dos desenhos da aula passada } \\
\text { Debate sobre a perspectiva de cada um, como cada um } \\
\text { escolhe e categoriza, recorta o mundo. } \\
\text { Territorializar nossa vivencia } \\
\text { Metáforas } \\
\text { Como guardamos as coisas na memória } \\
\text { A imagem na memória é em movimento ou parada? } \\
\text { Repertório }\end{array}$ \\
\hline $18 / 04$ & 19 & Linguagem & $\begin{array}{l}\text { Aula de linguagem } \\
\text { O fazer cinema e as várias áreas de atuação }\end{array}$ \\
\hline
\end{tabular}




\begin{tabular}{|c|c|c|c|}
\hline & & & $\begin{array}{l}\text { Repertório } \\
\text { Uso de material de apoio para aula (do projeto inventar com a } \\
\text { diferença) }\end{array}$ \\
\hline $25 / 04$ & 20 & $\begin{array}{l}\text { Cinema, } \\
\text { corpo e dança }\end{array}$ & $\begin{array}{l}\text { Aula de "cinema, corpo e dança" } \\
\text { Representação e os estereótipos sociais } \\
\text { Repertório }\end{array}$ \\
\hline $30 / 04$ & 21 & Linguagem & $\begin{array}{l}\text { Debate: pensar de forma critica os discursos que a televisão } \\
\text { disseminam sobre as favelas brasileiras e o poder do } \\
\text { audiovisual } \\
\text { Repertório }\end{array}$ \\
\hline $07 / 05$ & 22 & $\begin{array}{l}\text { Cinema, } \\
\text { corpo e dança }\end{array}$ & $\begin{array}{l}\text { Aula de "cinema, corpo e dança" } \\
\text { Imagens em movimento: tempo, dança e arte } \\
\text { *a partir desta data a mediadora começa a pensar mais } \\
\text { objetivamente em um trabalho específico e propõe aos alunos } \\
\text { que isso seja feito em conjunto com eles. } \\
\text { Noções de videoarte e videodança } \\
\quad \text { - O que é dança? } \\
\quad \text { - O que é arte? } \\
\text { - O que é tempo? } \\
\text { Repertório } \\
\text { (filmes experimentais) }\end{array}$ \\
\hline $09 / 05$ & 23 & Linguagem & $\begin{array}{l}\text { Aula de linguagem } \\
\text { Revisão de conceitos básicos } \\
\text { Uso de material de apoio para aula (do projeto inventar com a } \\
\text { diferença) } \\
\text { Roteiro baseado em: } \\
\text { - O que? (que ação/ gesto será executado no vídeo) } \\
\text { - Onde? (locação, podendo ser em espaço descontínuo) } \\
\text { - Como? (decupagem do roteiro utilizando as } \\
\text { linguagens: planos, posicionamento de câmera, } \\
\text { movimento de câmera) }\end{array}$ \\
\hline $14 / 05$ & 24 & $\begin{array}{l}\text { Cinema, } \\
\text { corpo e dança }\end{array}$ & $\begin{array}{l}\text { Aula de "cinema, corpo e dança" } \\
\text { O gesto e sua percepção: ângulo, gravidade, duração e relação } \\
\text { Roda de gestos } \\
\text { Acumulação de gesto } \\
\text { Inventar uma história e conta-la através de } 4 \text { gestos. Os outros } \\
\text { grupos observam de posicionamentos diferentes no espaço e } \\
\text { depois contavam sua interpretação. } \\
\text { Discutir a o limite/abertura dos signos gestuais sobre o } \\
\text { deslocamento dos sentidos na recepção do gesto do outro } \\
\text { Repertório } \\
\text { Dispositivo: roda de gestos. Inventar uma história e conta-la } \\
\text { através de } 4 \text { gestos. }\end{array}$ \\
\hline $16 / 05$ & 25 & Linguagem & $\begin{array}{l}\text { Aula de linguagem } \\
\text { Gravação dos roteiros do dia } 09 / 05\end{array}$ \\
\hline $21 / 05$ & 26 & Cinema, & Aula de "cinema, corpo e dança" \\
\hline
\end{tabular}




\begin{tabular}{|l|l|l|l|}
\hline & & corpo e dança & $\begin{array}{l}\text { O gesto do contexto, o contexto do gesto. Como um gesto } \\
\text { significa } \\
\text { Relação entre o gesto e a palavra } \\
\text { Como pode um gesto significar? } \\
\text { Gesto: a repetição como diferença }\end{array}$ \\
\hline $23 / 05$ & 27 & Linguagem & $\begin{array}{l}\text { Repertório } \\
\text { Eula de linguagem } \\
\text { Edição do material bruto da última aula } \\
\text { Relembrando planos }\end{array}$ \\
\hline $28 / 05$ & 28 & Linguagem & $\begin{array}{l}\text { Aula de linguagem } \\
\text { Repertório: Zózimo Bulbul + 5x favela } \\
\text { Fizeram uma discussão sobre o filme e os gestos }\end{array}$ \\
\hline
\end{tabular}




\section{Anexo 2}

Tabela com resumo de atividades dia a dia $\bullet 2^{\mathrm{a}}$ semestre $2014 \mid$ ELC

\begin{tabular}{|c|c|c|c|}
\hline Data & $\mathbf{N}^{\mathbf{o}}$ & Aula & Atividade \\
\hline $02 / 07$ & 29 & $\begin{array}{l}\text { Cinema, corpo e } \\
\text { dança }\end{array}$ & Tema, assunto e problema \\
\hline $09 / 07$ & 30 & $\begin{array}{l}\text { Cinema, corpo e } \\
\text { dança }\end{array}$ & Gestualidade como suporte estético \\
\hline $11 / 07$ & 31 & Linguagem & A importância do Repertório \\
\hline $16 / 07$ & 32 & $\begin{array}{l}\text { Cinema, corpo e } \\
\text { dança }\end{array}$ & $\begin{array}{l}\text { Gestualidade como suporte estético, parte } 2 . \\
\text { Execução de gesto }\end{array}$ \\
\hline $18 / 07$ & 33 & Linguagem & $\begin{array}{l}\text { Repertório (exibição do filme Pina (2011), do diretor } \\
\text { Win Wenders). }\end{array}$ \\
\hline $23 / 07$ & 34 & $\begin{array}{l}\text { Cinema, corpo e } \\
\text { dança }\end{array}$ & Execução de gestos (e manipulação). \\
\hline $25 / 07$ & 35 & Linguagem & $\begin{array}{l}\text { Linguagem, vídeo e dança } \\
\text { Sondagem para investigar a relação dos alunos com a } \\
\text { videodança } \\
\text { Repertório }\end{array}$ \\
\hline $30 / 07$ & 36 & $\begin{array}{l}\text { Cinema, vídeo e } \\
\text { dança }\end{array}$ & $\begin{array}{l}\text { Apresentação do projeto } \\
\text { Repertório e referencias } \\
\text { Coleção }\end{array}$ \\
\hline $01 / 08$ & 37 & Linguagem & $\begin{array}{l}\text { Detalhes do projeto } \\
\text { Repertório e referencias }\end{array}$ \\
\hline $06 / 08$ & 38 & $\begin{array}{l}\text { Cinema, corpo e } \\
\text { dança }\end{array}$ & $1^{\mathrm{a}}$ Coleção de imagens: seres vivos (bichos e plantas) \\
\hline $08 / 08$ & 39 & Linguagem & $2^{\mathrm{a}}$ Coleção de imagens: materialidades \\
\hline $13 / 08$ & 40 & $\begin{array}{l}\text { Cinema, corpo e } \\
\text { dança }\end{array}$ & $3^{\mathrm{a}}$ Coleção de imagens: grupos sociais \\
\hline $15 / 08$ & 41 & Linguagem & Análise do material - coleção \\
\hline $20 / 08$ & 42 & $\begin{array}{l}\text { Cinema, corpo e } \\
\text { dança }\end{array}$ & $4^{\mathrm{a}}$ Coleção de imagens: sensações e sentimentos \\
\hline $22 / 08$ & 43 & Linguagem & $\begin{array}{l}\text { Repertório } \\
\text { Exibição do filme "Contos da Maré" }\end{array}$ \\
\hline $27 / 08$ & 44 & Linguagem & 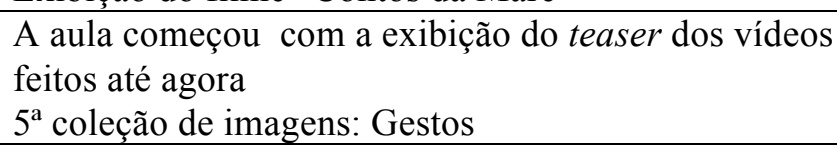 \\
\hline $29 / 08$ & 45 & $\begin{array}{l}\text { Cinema, corpo e } \\
\text { dança }\end{array}$ & $\begin{array}{l}\text { Retorno: } 4^{\text {a }} \text { coleção de imagens: sentimentos e } \\
\text { sensações } \\
\text { Trabalhando a coleção de sentimentos e sensações }\end{array}$ \\
\hline $03 / 09$ & 46 & Linguagem & Trabalhando a coleção de gestos \\
\hline $05 / 09$ & 47 & Linguagem & $\begin{array}{l}\text { Linguagem } \\
\text { exercício: } 3 \text { planos para } 1 \text { gesto }\end{array}$ \\
\hline $10 / 09$ & 48 & $\begin{array}{l}\text { Cinema, corpo e } \\
\text { dança }\end{array}$ & Procedimento coreográfico - gesto e sucessão \\
\hline $12 / 09$ & 49 & Linguagem & $\begin{array}{l}\text { Repertório e linguagem } \\
\text { Gravação (gestos) }\end{array}$ \\
\hline $17 / 09$ & 50 & $\begin{array}{l}\text { Cinema, vídeo e } \\
\text { dança }\end{array}$ & Trabalhando o quarteto de gestos \\
\hline $19 / 09$ & 51 & Linguagem & Gravação do quarteto de gestos \\
\hline
\end{tabular}




\begin{tabular}{|c|c|c|c|}
\hline $24 / 09$ & 52 & Linguagem & $\begin{array}{l}\text { Repertório } \\
\text { Exibição do filme Tomboy }\end{array}$ \\
\hline $26 / 09$ & 53 & Linguagem & $\begin{array}{l}\text { Gravação gestos } \\
\text { (como a câmera interage com o movimento?) }\end{array}$ \\
\hline $01 / 10$ & 54 & $\begin{array}{l}\text { Cinema, corpo e } \\
\text { danca }\end{array}$ & $\begin{array}{l}\text { Análise critica das últimas gravações } \\
\text { A construção do cenário e gravação }\end{array}$ \\
\hline $03 / 10$ & 55 & Linguagem & $\begin{array}{l}\text { Edição dos vídeos gravados na última aula } \\
\text { (os alunos assistiram a todos os vídeos gravados com a } \\
\text { turma, desde o primeiro) }\end{array}$ \\
\hline $08 / 10$ & 56 & $\begin{array}{l}\text { Cinema, corpo e } \\
\text { dança }\end{array}$ & $\begin{array}{l}\text { Rever os últimos vídeos gravados } \\
\text { Rever Re:Rosas! (referência da coreografia) } \\
\text { Repensar o espaço, construindo o cenário. }\end{array}$ \\
\hline $10 / 10$ & 57 & Linguagem & Planejando a reta final, novas metas \\
\hline $17 / 10$ & 58 & $\begin{array}{l}\text { Cinema, vídeo e } \\
\text { dança }\end{array}$ & $\begin{array}{l}1^{\text {a }} \text { gravação externa para o vídeo } \\
\text { Local: quadra de esportes, próximo a praça e a estação } \\
\text { de trem de Austin } \\
\text { Execução da coreografia "livre" na quadra, com as } \\
\text { cadeiras vermelhas da escola }\end{array}$ \\
\hline $22 / 10$ & 59 & $\begin{array}{l}\text { Cinema, corpo e } \\
\text { dança }+ \\
\text { linguagem }\end{array}$ & $\begin{array}{l}2^{\text {a }} \text { gravação externa para o vídeo } \\
\text { Local: Ladeira da igreja católica de Austin } \\
\text { *recalculando a rota: surge uma preocupação, a conexão } \\
\text { entre os trabalho desenvolvidos em cada turma, diante } \\
\text { disso, ao iniciar a aula os mediadores e alunos } \\
\text { procuraram assistir aos vídeos até então já gravados }\end{array}$ \\
\hline $28 / 10$ & 60 & $\begin{array}{l}\text { Cinema, corpo e } \\
\text { dança } \\
+ \text { linguagem }\end{array}$ & 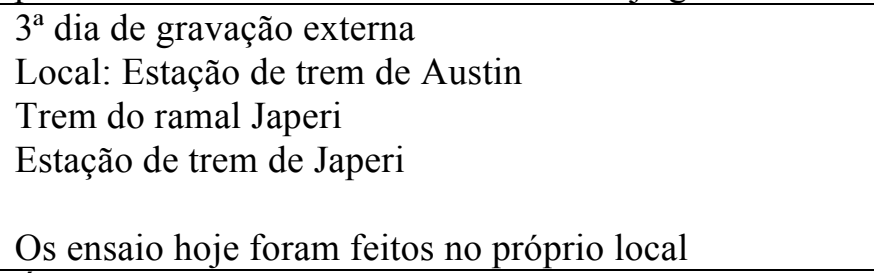 \\
\hline $31 / 10$ & 61 & $\begin{array}{l}\text { Cinema, corpo e } \\
\text { dança }+ \\
\text { linguagem }\end{array}$ & $\begin{array}{l}\text { Último dia de aula: } \\
\text { Apresentação do material bruto } \\
\text { Seleção dos vídeos que irão fazer parte do filme } \\
\text { Explicação sobre o processo de montagem }\end{array}$ \\
\hline $29 / 11$ & 62 & & $\begin{array}{l}\text { Lançamento do vídeo Montão de Coisa, na sede da } \\
\text { escola em Austin }\end{array}$ \\
\hline
\end{tabular}




\section{Anexo 3}

Lista de referências trabalhadas durante as aulas na ELC em 2014

\begin{tabular}{|c|c|c|}
\hline Obra & Autor & $\begin{array}{l}\text { Fragmento ou filme } \\
\text { inteiro }\end{array}$ \\
\hline Pequena Miss Sunshine & $\begin{array}{l}\text { Jonathan Dayton / } \\
\text { Valerie Faris }\end{array}$ & fragmento \\
\hline $\begin{array}{l}\text { A Deusa da Misericórdia de Mil } \\
\text { Braços. Ballet das dançarinas surdas }\end{array}$ & $\begin{array}{l}\text { coreógrafo chinês Zhang } \\
\text { Jigang }\end{array}$ & completo \\
\hline Clip da música Kagado & $\begin{array}{l}\text { Os Kazumbis feat Cabo } \\
\text { Snoop }\end{array}$ & completo \\
\hline Coletânea Lumière & irmãos Lumière & completo \\
\hline Footloose (filme) & & fragmento \\
\hline Smooth Criminal (clipe) & Michael Jackson & completo \\
\hline Soul Train 1973 / 74 (programa) & & fragmento \\
\hline Videoinstalação \#circulando & ELC & completo \\
\hline Videoinstalação \#QueroSer & ELC & completo \\
\hline A Batalha do Passinho & Emílio Domingos & completo \\
\hline Losing you & Solange Knowles & \\
\hline Hiroshima mon amour & Alain Resnais & fragmento \\
\hline Danse serpentine [II] & irmãos Lumière & completo \\
\hline $\begin{array}{l}\text { Danse serpentine par Madame Bob- } \\
\text { Walter»,[Danse serpentine } \\
\text { Mademoiselle Paola Welther] }\end{array}$ & $\begin{array}{l}\text { Alice Guy, Léon } \\
\text { Gaumont \& Cie }\end{array}$ & \\
\hline Danse serpentine & Loïe Fuller & completo \\
\hline Ameta & $\begin{array}{l}\text { American Mutoscope \& } \\
\text { Biograph Co }\end{array}$ & completo \\
\hline Serpentine Dance & Lina Esbrard & completo \\
\hline A Study In Choreography For Camera & Maya Deren & completo \\
\hline 5x Favela - agora por nós mesmos & $\begin{array}{l}\text { Cacau Amaral, Luciano } \\
\text { Vidigal, Rodrigo Felha, } \\
\text { Cadu Barcelos, Luciana } \\
\text { Bezerra, Wagner } \\
\text { Novais, Manaira } \\
\text { Carneiro }\end{array}$ & completo \\
\hline Deixa Voar & Cadu Barcellos & fragmento \\
\hline Mobile Men & Apitchatpong Weres & completo \\
\hline Screen tests & Andy Warhol & completo \\
\hline Bem-te-vi & $\begin{array}{l}\text { Luisa Coser, oficina de } \\
\text { Vido-retratos Dança em } \\
\text { Foco } 2010\end{array}$ & completo \\
\hline Bolt - Super Cão & $\begin{array}{l}\text { Byron Howard, Chris } \\
\text { Williams }\end{array}$ & fragmento \\
\hline Farenheit 451 & François Truffaut & fragmento \\
\hline
\end{tabular}




\begin{tabular}{|c|c|c|}
\hline Private life of a cat & Maya Deren & completo \\
\hline Not I & Becket & completo \\
\hline Hand movie & Yvonne Rainer & completo \\
\hline Bridges-Go-Round & Shirley Clarke & completo \\
\hline Jornada ao umbigo do Mundo & $\begin{array}{l}\text { Alice Ripol e Alex } \\
\text { Cassal }\end{array}$ & completo \\
\hline Uberlin & REM & completo \\
\hline $\begin{array}{l}\text { Fragmentos do Inventar com a } \\
\text { diferença }\end{array}$ & Inventar com a diferença & fragmento \\
\hline Le Diable Noir & Méliès & completo \\
\hline A Chegada do trem & Irmãos Lumiére & completo \\
\hline Nunca fui, mas me disseram & $\begin{array}{l}\text { Bruno Vianna, } \\
\text { Jacqueline Martins, } \\
\text { Priscila Marques, Taisa } \\
\text { Moreno e Verônica } \\
\text { Trindade }\end{array}$ & completo \\
\hline 12 Anos de Escravidão & Steve McQueen & fragmento \\
\hline Three Transitions & Peter Campus & completo \\
\hline Ritual in Transfigured Time & Maya Deren & completo \\
\hline Neighbours & Norman McLaren & completo \\
\hline Sensações Contrarias & $\begin{array}{l}\text { Amadeu Alban, Jorge } \\
\text { Alencar e Matheus } \\
\text { Rocha }\end{array}$ & completo \\
\hline TANGO & Zbigniew Rybczyński & fragmento \\
\hline Le P'tit Bal perdu & Philippe Decouflé & completo \\
\hline Alma no Olho & Zózimo Bulbul & completo \\
\hline Capitu, Rede Globo & Rede Globo & fragmento \\
\hline A Chairy Tale & Norman McLaren & completo \\
\hline Café Müller & Pina Bausch & completo \\
\hline A Sagração da Primavera & Pina Bausch & completo \\
\hline PES & PES & completo \\
\hline Ilha das Flores & Jorge Furtado & completo \\
\hline Arroz com Feijão & $\begin{array}{l}\text { Cacau Amaral, Luciano } \\
\text { Vidigal, Rodrigo Felha, } \\
\text { Cadu Barcelos, Luciana } \\
\text { Bezerra, Wagner } \\
\text { Novais, Manaira } \\
\text { Carneiro }\end{array}$ & fragmento \\
\hline O baile & Ettore Scola & fragmento \\
\hline Pina & Win Wenders & fragmento \\
\hline Re:Rosas & $\begin{array}{l}\text { Anne Tereza De } \\
\text { Keersmaeker }\end{array}$ & completo \\
\hline Arthur Bispo do Rosário & Arthur Bispo do Rosário & fragmento \\
\hline Dead Leaves and the dirty ground & The White Stripes & completo \\
\hline Sweate & Willow & completo \\
\hline Passinho do Romano & $\begin{array}{l}\text { Bonde TNT e Lucas } \\
\text { Santos }\end{array}$ & completo \\
\hline
\end{tabular}




\begin{tabular}{|l|l|l|} 
Around the world & Daft Punk & completo \\
\hline Contos da Maré & Douglas Soares & completo \\
\hline Tomboy & Céline Sciamma & completo \\
\hline
\end{tabular}




\section{Anexo 4}

Lista de exercícios trabalhados durante o ano na ELC

\begin{tabular}{|c|c|c|c|}
\hline Data & Exercício & Detalhes & \\
\hline $12 / 02 / 14$ & Abecedário & $\begin{array}{l}\text { Fazer um abecedário com palavras } \\
\text { relacionadas à dança }\end{array}$ & $\begin{array}{l}\text { exercício para } \\
\text { mapear } \\
\text { universo da } \\
\text { dança }\end{array}$ \\
\hline $19 / 02 / 14$ & Minuto Lumière & $\begin{array}{l}\text { Os alunos pediram para sair da escola, mas } \\
\text { inicialmente não tinha um lugar definido e } \\
\text { nem ideia de onde e o que iriam filmar. } \\
\text { Seguindo pela rua principal (comércio de } \\
\text { Austin), eles foram até a estação de trem. } \\
\text { Um dos alunos, ainda sem ter ideia do que } \\
\text { queria/iria filmar, fez imagens da chegada } \\
\text { do trem, o exercício foi repetido, pois a } \\
\text { proposta era não mexer na câmera (filmar } \\
\text { uma cena ou situação). Ele repetiu o } \\
\text { exercício do mesmo lugar. }\end{array}$ & $\begin{array}{l}\text { exercício de } \\
\text { filmagem na } \\
\text { rua }\end{array}$ \\
\hline $21 / 02 / 14$ & $\begin{array}{l}\text { Refazer Minuto } \\
\text { Lumière }\end{array}$ & $\begin{array}{l}\text { Os alunos são encorajados à voltarem para a } \\
\text { rua e refazer seus vídeos. Os lugares foram } \\
\text { os mesmos, a ideia era filmar do mesmo } \\
\text { lugar (obviamente, novas cenas poderiam } \\
\text { surgir). } \\
\text { Depois, os alunos voltam para sala e } \\
\text { assistiram aos novos vídeos }\end{array}$ & $\begin{array}{l}\text { exercício de } \\
\text { filmagem na } \\
\text { rua }\end{array}$ \\
\hline $26 / 02 / 14$ & $\begin{array}{l}\text { Exercício } \\
\text { explorando } \\
\text { velocidade da luz }\end{array}$ & $\begin{array}{l}\text { Exercício prático utilizando a técnica de } \\
\text { "lighting painting". }\end{array}$ & $\begin{array}{l}\text { exercício com } \\
\text { conceitos da } \\
\text { linguagem em } \\
\text { sala }\end{array}$ \\
\hline $12 / 03 / 14$ & $\begin{array}{l}\text { Descrever } \\
\text { imagens }\end{array}$ & $\begin{array}{l}\text { Descrever as imagens vistas nos vídeos de } \\
\text { referência }\end{array}$ & $\begin{array}{l}\text { exercício feito } \\
\text { a partir de } \\
\text { vídeos de } \\
\text { dança, usados } \\
\text { como } \\
\text { referência }\end{array}$ \\
\hline $14 / 03 / 14$ & Planos & $\begin{array}{l}\text { Filmar } 3 \text { planos diferentes da mesma ação. } \\
\text { Trabalhando plano e enquadramento } \\
\text { (trabalhando especialmente o conceito de } \\
\text { Raccord) }\end{array}$ & $\begin{array}{l}\text { exercício de } \\
\text { linguagem }\end{array}$ \\
\hline $19 / 03 / 14$ & $\begin{array}{l}\text { Exercícios para o } \\
\text { olhar }\end{array}$ & $\begin{array}{l}\text { Cada aluno desenhou e recortou } 3 \text { círculos } \\
\text { numa folhas, de tamanhos diferentes, como } \\
\text { se fossem olhos, foi feito um exercício de } \\
\text { olhar pelos furos afastando e aproximando } \\
\text { de objetos e também sendo conduzido por } \\
\text { um guia a olhar o que este indicasse. }\end{array}$ & $\begin{array}{l}\text { exercício / - } \\
\text { quem esta } \\
\text { olhando o } \\
\text { que? Onde } \\
\text { esta o olho? }\end{array}$ \\
\hline $02 / 04 / 14$ & $\begin{array}{l}\text { Do percurso a } \\
\text { narrativa: a } \\
\text { metáfora como } \\
\text { exercício poético }\end{array}$ & $\begin{array}{l}\text { No exercício prático a turma foi dividida em } \\
\text { grupos de } 3 \text { e } 4 \text { e foram distribuídos jornais, } \\
\text { cada grupo tinha que escolher uma matéria } \\
\text { de jornal e transforma-la num "roteiro" } \\
\text { como uma possibilidade de interação entres } \\
\text { os alunos e criatividade a partir dos temas } \\
\text { abordados. }\end{array}$ & $\begin{array}{l}\text { Exercício } \\
\text { "olhar } \\
\text { subjetivo" e } \\
\text { "câmera-que- } \\
\text { dança"/ } \\
\text { Objetivando } \\
\text { pensar como } \\
\text { criar um } \\
\text { percurso- }\end{array}$ \\
\hline
\end{tabular}




\begin{tabular}{|c|c|c|c|}
\hline & & & $\begin{array}{l}\text { filmado de } \\
\text { forma não } \\
\text { literal e linear. }\end{array}$ \\
\hline $09 / 04 / 14$ & $\begin{array}{l}\text { Exercício } \\
\text { Perceber o espaço, } \\
\text { caminhada } \\
\text { silenciosa }\end{array}$ & $\begin{array}{l}\text { 1. Exercício de caminhada silenciosa com } \\
\text { observação-participante por Austin com } \\
\text { parada em três pontos do bairro. } \\
\text { 2. Divididos em duplas, cada um fez o } \\
\text { contorno do seu corpo numa folha de papel } \\
\text { e escreveu 'tudo que registrou' durante a } \\
\text { caminhada silenciosa. } \\
\text { Objetivos: Sensibilizar e ativar para os } \\
\text { 'estados físicos e emocionais' de cada um } \\
\text { ao observar o trajeto em movimento para } \\
\text { aos poucos ir trazendo a noção de } \\
\text { propriocepção, ativando interesses e } \\
\text { escolhas para o que olha. Despertar para os } \\
\text { sentidos do corpo e para a diferença entre } \\
\text { gesto e movimento. }\end{array}$ & $\begin{array}{l}\text { Observando o } \\
\text { caminho: } \\
\text { movimento, } \\
\text { subjetividade } \\
\text { e } \\
\text { propriocepção }\end{array}$ \\
\hline $16 / 04 / 14$ & $\begin{array}{l}\text { Exercício } \\
\text { memória }\end{array}$ & $\begin{array}{l}\text { Como guardamos as coisas na memórias? } \\
\text { Como acessamos nossos registros? } \\
\text { Descrevam a imagem que cada palavra tem } \\
\text { e qual a sensação ao lembrar da imagem. } \\
\text { A imagem que vem à memória esta em } \\
\text { movimento ou parada? }\end{array}$ & $\begin{array}{l}\text { Exercício } \\
\text { explora como } \\
\text { guardamos as } \\
\text { coisas na } \\
\text { memória }\end{array}$ \\
\hline $09 / 05 / 14$ & $\begin{array}{l}\text { Exercício de } \\
\text { Roteiro }\end{array}$ & $\begin{array}{l}\text { os alunos se dividiram em grupos para } \\
\text { pensar um roteiro simples, norteado por três } \\
\text { perguntas: } \\
\text { - O que? ( que ação/ gesto será executado no } \\
\text { vídeo) } \\
\text { - Onde? (locação, podendo ser em espaço } \\
\text { descontinuo) } \\
\text { - Como? (Decoupagem do roteiro utilizando } \\
\text { as linguagens: Planos, Posicionamento de } \\
\text { câmera, Movimento de câmera). }\end{array}$ & $\begin{array}{l}\text { Exercício } \\
\text { aparece como } \\
\text { uma revisão } \\
\text { das aulas } \\
\text { anteriores }\end{array}$ \\
\hline
\end{tabular}




\begin{tabular}{|c|c|c|c|c|}
\hline 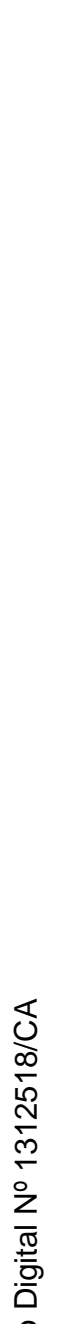 & $14 / 05.2014$ & $\begin{array}{l}\text { Exercício Roda de } \\
\text { Gestos }\end{array}$ & $\begin{array}{l}\text { Em circulo, foi feita uma introdução de cada } \\
\text { um falando seu nome até completar o } \\
\text { circulo. A proposta era bater duas palmas e } \\
\text { dizer o seu nome naquela duração. Em } \\
\text { seguida, cada um dizia livremente o nome } \\
\text { de outro da roda que pegaria a vez e assim } \\
\text { por diante. } \\
\text { 1. Roda de gestos: fazer um gesto que seria } \\
\text { repetido por todos logo após. A ideia é se } \\
\text { conscientizar da nossa percepção da } \\
\text { qualidade do movimento do outro, da } \\
\text { intensidade, da duração e conseguir repeti-lo } \\
\text { tal qual. } \\
\text { 2. Acumulação de gesto: fazer um gesto, a } \\
\text { pessoa seguinte deve repetir esse primeiro } \\
\text { gesto e adicionar outro, a terceira pessoa } \\
\text { deve repetir os dois primeiros gestos e } \\
\text { adicionar outro e assim por diante. } \\
\text { 3. Foram criados } 3 \text { grupos, o grupo } 1 \text { tinha } \\
\text { que inventar uma historia e conta-la através } \\
\text { de } 4 \text { gestos. Os outros } 2 \text { grupos observavam } \\
\text { de posicionamentos diferentes no espaço e } \\
\text { depois contavam sua interpretação. E depois } \\
\text { foi feito revezamento dos papeis. } \\
\text { O objetivo desta pratica foi discutir o } \\
\text { limite/abertura dos signos gestuais, sobre os } \\
\text { deslocamentos dos sentidos na recepção do } \\
\text { gesto do outro (como a ação do outro me } \\
\text { afeta) e introduzir o assunto de planos, } \\
\text { duração para realização e qualidade } \\
\text { gestuais. }\end{array}$ & $\begin{array}{l}\text { O gesto e sua } \\
\text { percepção: } \\
\text { ângulo, } \\
\text { gravidade, } \\
\text { duração, } \\
\text { relação }\end{array}$ \\
\hline 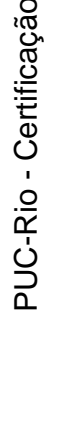 & $16 / 05 / 14$ & $\begin{array}{l}\text { Gravação do } \\
\text { roteiro }\end{array}$ & $\begin{array}{l}\text { Os roteiros trabalhados na aula de } \\
09 / 05 / 2014 \text { foram finalizados na aula de } \\
\text { hoje e impressos. Com roteiro em mãos, os } \\
\text { alunos foram divididos em dois grupos e } \\
\text { orientados pelos mediadores durante a } \\
\text { gravação. } \\
\text { A proposta dos mediadores era que todos os } \\
\text { alunos participassem ativamente da } \\
\text { gravação, reversando-se nas diversas } \\
\text { funções (gravação, atuação e direção). }\end{array}$ & $\begin{array}{l}\text { Roteiro em } \\
\text { mãos e } \\
\text { gravações }\end{array}$ \\
\hline
\end{tabular}




\begin{tabular}{|c|c|c|c|}
\hline $21 / 05 / 14$ & $\begin{array}{l}\text { Análise de uma } \\
\text { imagem }\end{array}$ & $\begin{array}{l}\text { a mediadora trabalhou a relação entre gesto } \\
\text { e palavra, discutindo sobre a interrelação } \\
\text { entre palavra e ação gestual e a não } \\
\text { suficiência da palavra falada para objetivar } \\
\text { seu conteúdo. Abordando a liberdade } \\
\text { semântica dos conteúdos gestuais e como } \\
\text { estes conteúdos variam suas representações } \\
\text { formais de acordo com o contexto e o } \\
\text { observador. } \\
\text { A mediadora utilizou novamente um } \\
\text { exemplo a partir de um gesto comum como } \\
\text { "dar tchau", cruzar os braços e esfregar os } \\
\text { dedos. A partir desta pergunta "como pode } \\
\text { um gesto significar?" } \\
\text { O objetivo da aula era provocar uma leitura } \\
\text { de gestos mais aberta, descritiva e inventiva. } \\
\text { Ao invés de perguntar "o que significa este } \\
\text { gesto?", a mediadora motivou a leitura do } \\
\text { desenho que uma ação gestual tem, qual a } \\
\text { relação que se cria, quais as linhas de força, } \\
\text { o peso, sem esquecer de onde se vê o que } \\
\text { esta acontecendo e como se vê. } \\
\text { Analisamos uma imagem: A criação de } \\
\text { Adão, feita por Michelangelo. }\end{array}$ & $\begin{array}{l}\text { O gesto do } \\
\text { contexto, o } \\
\text { contexto do } \\
\text { gesto. Como } \\
\text { um gesto } \\
\text { significa? }\end{array}$ \\
\hline $23 / 05 / 14$ & $\begin{array}{l}\text { Exercício de } \\
\text { edição }\end{array}$ & $\begin{array}{l}\text { Mediadores e alunos trabalham juntos na } \\
\text { edição do material bruto das gravações do } \\
\text { dia } 16 / 05 / 2014 \text {. O mediador edita o trabalho } \\
\text { no software e os alunos direcionam a } \\
\text { montagem da cena, a escolha dos cortes etc. } \\
\text { Durante todo processo de montagem o } \\
\text { mediador recapitula qual o movimento de } \\
\text { câmera usado, o nome do plano etc. } \\
\text { Explorando a linguagem cinematográfica. }\end{array}$ & $\begin{array}{l}\text { Montar uma } \\
\text { cena }\end{array}$ \\
\hline $02 / 07 / 14$ & $\begin{array}{l}\text { Exercício para } \\
\text { compreender o } \\
\text { que é um tema }\end{array}$ & $\begin{array}{l}\text { A turma foi dividida em grupo. A mediadora } \\
\text { pediu para que os alunos escolhessem um } \\
\text { tema, identificasse um problema para ser } \\
\text { resolvido e defendesse esse projeto para } \\
\text { turma: "por que queremos falar disso dessa } \\
\text { forma?" }\end{array}$ & $\begin{array}{l}\text { Tema, assunto } \\
\text { e problema }\end{array}$ \\
\hline $09 / 07 / 14$ & Exercício de gesto & $\begin{array}{l}\text { Pratica/ Cada aluno escolheu um gesto de } \\
\text { uma imagem dos livros observados e, em } \\
\text { roda, os gestos foram realizados um após o } \\
\text { outro. Depois variamos } \\
\text { as dinâmicas de apresentação. }\end{array}$ & $\begin{array}{l}\text { Gestualidade } \\
\text { como suporte } \\
\text { estético }\end{array}$ \\
\hline
\end{tabular}




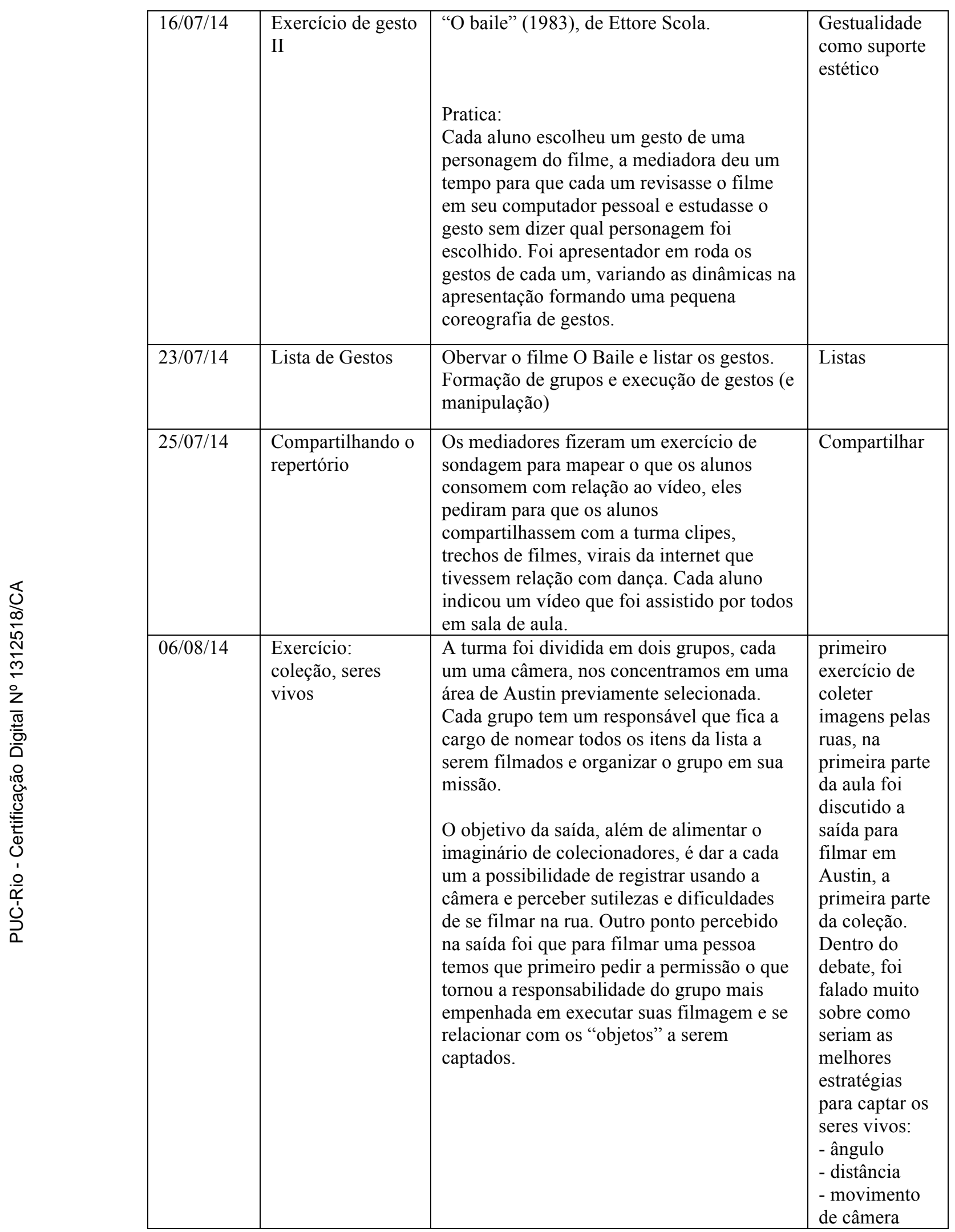




\begin{tabular}{|c|c|c|c|c|}
\hline & $08 / 08 / 14$ & $\begin{array}{l}\text { Exercício: } \\
\text { coleção, } \\
\text { materialidades }\end{array}$ & $\begin{array}{l}\text { Novamente a turma foi divida em dois } \\
\text { grupos, dois representantes de cada grupo } \\
\text { foram responsáveis por anotar as ideias dos } \\
\text { integrantes. } \\
\text { Fizemos e percurso curto por Austin e os } \\
\text { mediadores pediram que os alunos } \\
\text { observassem atentamente os detalhes (cores } \\
\text { e texturas) dos lugares onde passávamos. } \\
\text { Escolhido o motivo da filmagem, o aluno } \\
\text { utilizando a lente fechada realizava um } \\
\text { vídeo de } 30 \text { segundos com a câmera parada. }\end{array}$ & $\begin{array}{l}\text { Antes de sair } \\
\text { para fazer } \\
\text { gravações na } \\
\text { rua, os } \\
\text { mediadores } \\
\text { falaram mais } \\
\text { uma vez sobre } \\
\text { as funções da } \\
\text { câmera } \\
\text { (Canon T3i). }\end{array}$ \\
\hline 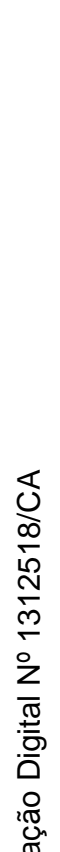 & $13 / 08 / 14$ & $\begin{array}{l}\text { Exercício: } \\
\text { coleção, grupo } \\
\text { social }\end{array}$ & $\begin{array}{l}\text { A aula começa com a mediadora } \\
\text { apresentando as imagens gravadas na aula } \\
\text { de } 06 \text { de agosto (seres vivos). Juntos eles } \\
\text { analisam as imagens, enfatizando os } \\
\text { aspectos técnicos. Em sala, a mediadora } \\
\text { pergunta aos alunos como podíamos } \\
\text { identificar um grupo social. Quais são os } \\
\text { critérios e categorias para se delimitar um } \\
\text { grupo? Como as relações inerentes ao } \\
\text { contexto são preponderantes para a } \\
\text { observação e formação de um possível } \\
\text { grupo social? Os alunos participaram dando } \\
\text { exemplos, do micro ao macro, de situações } \\
\text { de grandeza social e no plano doméstico e } \\
\text { cotidiano. Num segundo momento tentamos } \\
\text { identificar como seriam as melhores } \\
\text { maneiras então de filmar um aglomerado de } \\
\text { gente: } \\
\text { - perspectiva, distância e movimento de } \\
\text { câmera, intenção e objetivo durante a } \\
\text { captação. }\end{array}$ & $\begin{array}{l}\text { Videoclipe do } \\
\text { grupo Daft } \\
\text { Punk, } \\
\text { "Around the } \\
\text { world", } \\
\text { dirigido por } \\
\text { Michel } \\
\text { Gondry, para } \\
\text { integrar a idéia } \\
\text { de } \\
\text { coreografia/ } \\
\text { ritmo a } \\
\text { formação de } \\
\text { grupos sociais. }\end{array}$ \\
\hline 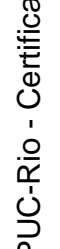 & $15 / 08 / 14$ & $\begin{array}{l}\text { Avaliação do } \\
\text { material coletado }\end{array}$ & $\begin{array}{l}\text { Os mediadores que trabalham mais } \\
\text { especificamente com as questões } \\
\text { relacionadas à linguagem cinematográfica } \\
\text { usaram a aula para avaliar o material } \\
\text { coletado até o momento, fazendo } \\
\text { interferências, dando dicas e criticando. }\end{array}$ & \\
\hline
\end{tabular}




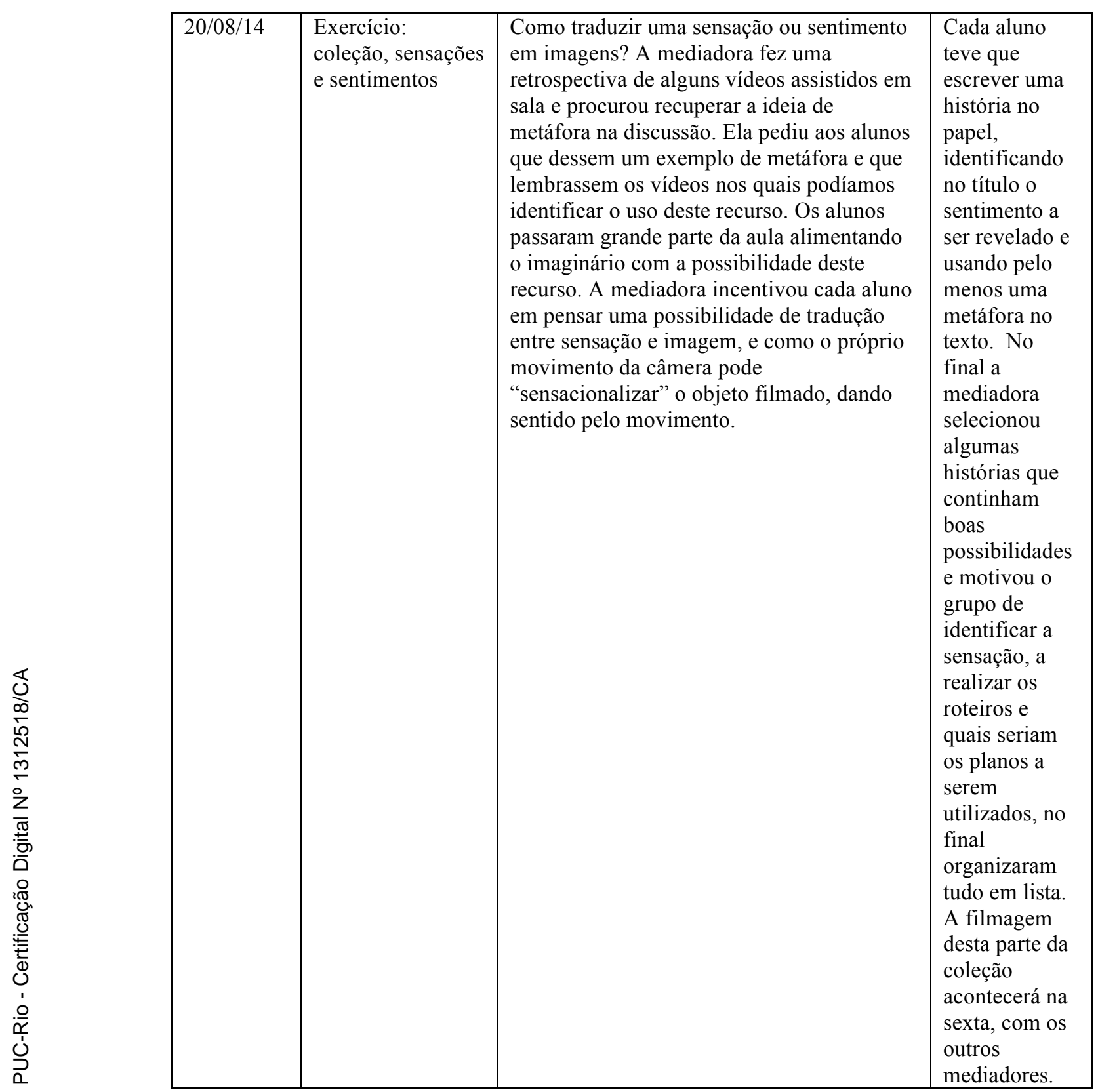




\begin{tabular}{|c|c|c|c|}
\hline $27 / 08 / 14$ & $\begin{array}{l}\text { Exercício: } \\
\text { coleção, gestos }\end{array}$ & $\begin{array}{l}\text { As aulas sobre gestos retornaram e a } \\
\text { mediadora atualizei os elementos a serem } \\
\text { pensados na confecção do gesto para a } \\
\text { câmera, que são: tempo (duração, ritmo e } \\
\text { repetição); transição; intenção e efeito. } \\
\text { Decidimos coletar os gestos a partir dos } \\
\text { vídeos feitos pelos alunos nas ruas de } \\
\text { Austin, já catalogados. } \\
\text { Parte prática: } \\
\text { A. Cada aluno escolheu um gesto de alguma } \\
\text { cena da coleção feita, podendo ser um gesto- } \\
\text { para-tradução, ou seja, de uma árvore ou de } \\
\text { um animal, ou objeto. Em seguida, } \\
\text { individualmente ou em grupo eles } \\
\text { estudaram os gestos e filmamos } \\
\text { separadamente depois. } \\
\text { B. Juntamos os gestos espacialmente: cada } \\
\text { aluno se posicionou no espaço e foi } \\
\text { realizando o gesto a medida que a câmera } \\
\text { passava, um roteiro coreográfico! }\end{array}$ & $\begin{array}{l}\text { Neste dia a } \\
\text { aula começou } \\
\text { com a } \\
\text { apresentação } \\
\text { de um teaser } \\
\text { feito com as } \\
\text { cenas } \\
\text { catalogadas } \\
\text { até agora. O } \\
\text { vídeo foi } \\
\text { editado por } \\
\text { um dos } \\
\text { mediadores, } \\
\text { que usou } \\
\text { como critérios } \\
\text { de escolha a } \\
\text { qualidade } \\
\text { técnica do } \\
\text { vídeo e a } \\
\text { duração (10 } \\
\text { segundos). }\end{array}$ \\
\hline $29 / 08 / 14$ & $\begin{array}{l}\text { Exercício: } \\
\text { coleção, sensações } \\
\text { e sentimentos }\end{array}$ & $\begin{array}{l}\text { Nesta aula os mediadores retomaram as } \\
\text { ideias trabalhadas no dia } 20 \text { de agosto } \\
\text { (sensações e sentimentos) e os alunos } \\
\text { continuaram trabalhando em roteiro para } \\
\text { possíveis cenas. }\end{array}$ & \\
\hline $03 / 09 / 14$ & $\begin{array}{l}\text { Exercício: } \\
\text { trabalhando a } \\
\text { coleção de gestos }\end{array}$ & $\begin{array}{l}\text { Assistimos aos vídeos feitos nas ultimas } \\
\text { aulas sobre gestos e a coleção de sensações } \\
\text { e sentimentos. } \\
\text { Parte prática: } \\
\text { A. Cada um mostrou novamente seu gesto e } \\
\text { a mediadora (responsável pelas aulas de } \\
\text { corpo e dança) expôs, junto com o mediador } \\
\text { (responsável pelas aulas de linguagem), a } \\
\text { necessidade de precisão e clareza na } \\
\text { realização, sobretudo quando imaginado } \\
\text { para ser filmado. A mediadora perguntou a } \\
\text { cada um qual era a intenção do seu gesto e } \\
\text { pediu para que o fizessem algumas vezes } \\
\text { explorando e melhorando a qualidade } \\
\text { (observando sempre: tempo, repetição, } \\
\text { transição e intenção). } \\
\text { B. O desenvolvimento da atividade é ensinar } \\
\text { seu gesto aos outros da turma e que todo } \\
\text { mundo conheça e saiba fazer o gesto do } \\
\text { outro. }\end{array}$ & $\begin{array}{l}\text { Objetivo: } \\
\text { O objetivo } \\
\text { desse trabalho } \\
\text { feito pela } \\
\text { mediadora é } \\
\text { que quando } \\
\text { todos } \\
\text { conhecerem o } \\
\text { gesto do outro } \\
\text { podemos } \\
\text { brincar mais } \\
\text { coreograficam } \\
\text { ente com a } \\
\text { ideia da } \\
\text { continuidade e } \\
\text { descontinuida } \\
\text { de e } \\
\text { deslocamentos } \\
\text { espaciais. }\end{array}$ \\
\hline
\end{tabular}




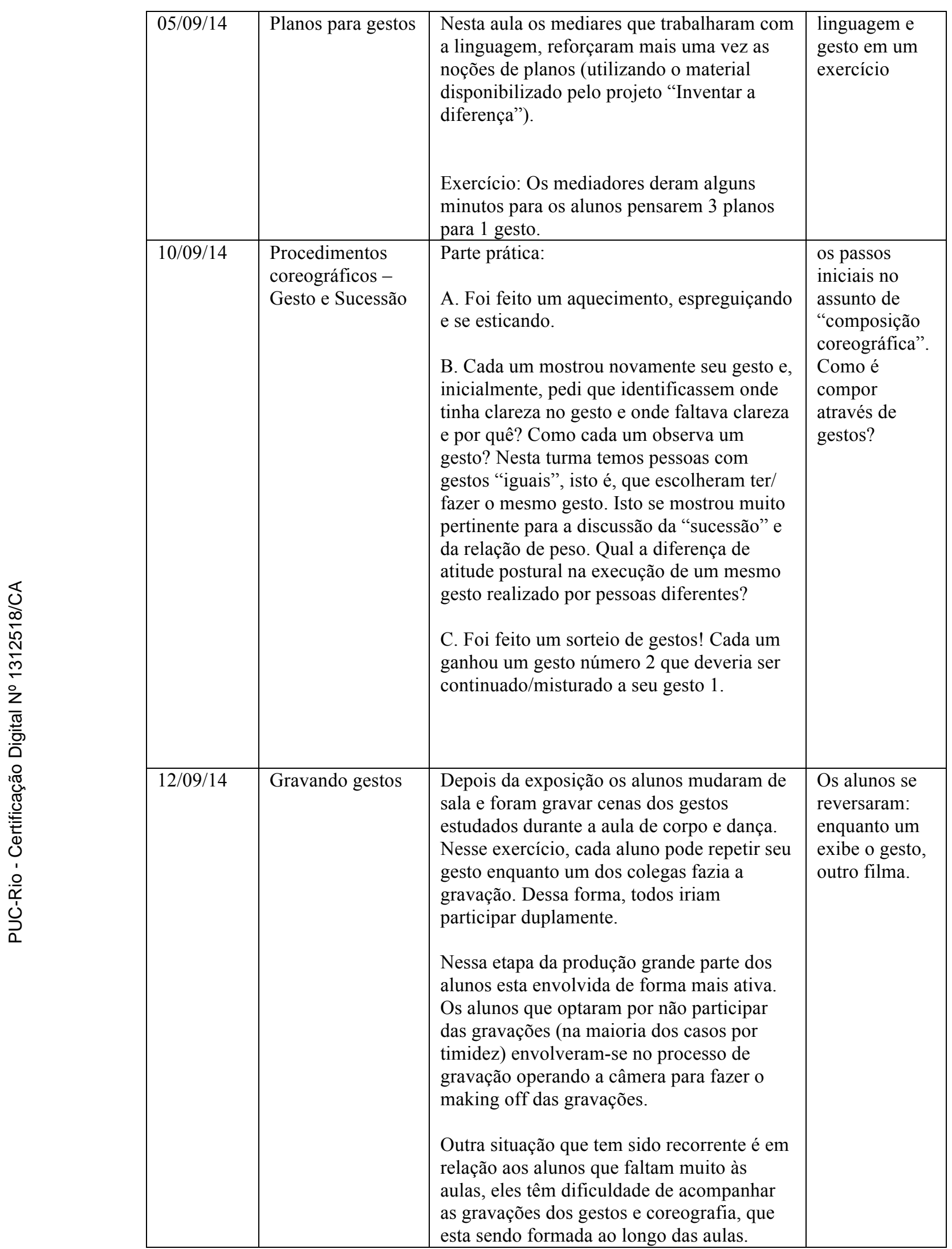




\begin{tabular}{|c|c|c|c|c|}
\hline & $17 / 09 / 14$ & Quarteto de gestos & $\begin{array}{l}\text { A lista de gestos se transforma em dupla de } \\
\text { gestos. Depois disso, as duplas se uniram, } \\
\text { formando um quarteto de gestos. Por } \\
\text { exemplo: Grupo A: Panfleto + cartas / } \\
\text { espreguiçar + Confeti e Embaixadinhas + } \\
\text { cartas / espreguiçar + panfleto } \rightarrow \text { Um } \\
\text { quarteto de gestos. } \\
\text { Prática: } \\
\text { Depois de ensaiarem em sala, os alunos } \\
\text { foram para o terraço fazer a gravação do } \\
\text { quarteto de gestos ( } 2 \text { grupos). }\end{array}$ & $\begin{array}{l}\text { Diante disso a } \\
\text { mediadora } \\
\text { trabalhou: } \\
\text { Uma "ordem" } \\
\text { sendo } \\
\text { misturada } \\
\text { "velocidade" e } \\
\text { "intensidade" } \\
\text { A forma de } \\
\text { execução do } \\
\text { gesto e o } \\
\text { deslocamento } \\
\text { ou não no } \\
\text { espaço. }\end{array}$ \\
\hline 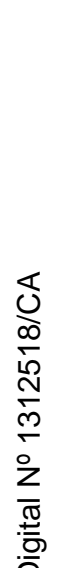 & $26 / 09 / 14$ & $\begin{array}{l}\text { Como a câmera } \\
\text { vai interagir com } \\
\text { o movimento? }\end{array}$ & $\begin{array}{l}\text { Os alunos voltaram a formação dos dois } \\
\text { grandes grupos e inicialmente com papel e } \\
\text { lápis foram incentivados a pensar o } \\
\text { movimento da câmera. Depois foram para } \\
\text { outra sala e fizeram a gravação do quarteto } \\
\text { de gestos de cada grupo. }\end{array}$ & $\begin{array}{l}\text { Os mediadores } \\
\text { que trabalham } \\
\text { com } \\
\text { linguagem } \\
\text { deram ênfase } \\
\text { aos } \\
\text { movimentos } \\
\text { da câmera, } \\
\text { ajudando os } \\
\text { alunos a } \\
\text { pensarem } \\
\text { através da } \\
\text { linguagem do } \\
\text { videoclip }\end{array}$ \\
\hline 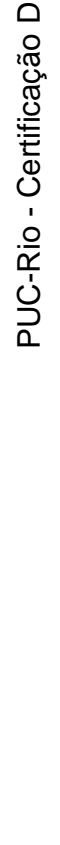 & $01 / 10 / 14$ & $\begin{array}{l}\text { Sobre a } \\
\text { construção do } \\
\text { cenário }\end{array}$ & $\begin{array}{l}\text { Os grupos assistiram aos vídeos produzidos } \\
\text { nas últimas aulas e a mediadora pediu que } \\
\text { os alunos observassem criticamente os } \\
\text { gestos, pensando quais os gestos que estão } \\
\text { sendo melhor executados e quais os gestos } \\
\text { que não estão ficando bons. } \\
\text { Como as gravações são feitas em dois } \\
\text { grupos, a turma fez a avaliação da seguinte } \\
\text { forma: } \\
\text { - Grupo A faz a avaliação do grupo B. } \\
\text { - Grupo B faz a avaliação do grupo A. } \\
\text { Depois da avaliação a mediadora propõe que } \\
\text { cada grupo escolha um cenário para o outro } \\
\text { (os cenários são no terraço da escola), a } \\
\text { partir da escolha do grupo, o outro grupo } \\
\text { precisa adaptar sua coreografia (seu quarteto } \\
\text { de gestos) no cenário, executar } 2 \\
\text { movimentos, os mediadores fizeram a } \\
\text { gravação. }\end{array}$ & $\begin{array}{l}\text { Construção do } \\
\text { cenário. } \\
\text { Observação } \\
\text { critica do } \\
\text { trabalho feito } \\
\text { (especialmente } \\
\text { do conjunto de } \\
\text { gestos } \\
\text { formado). }\end{array}$ \\
\hline
\end{tabular}




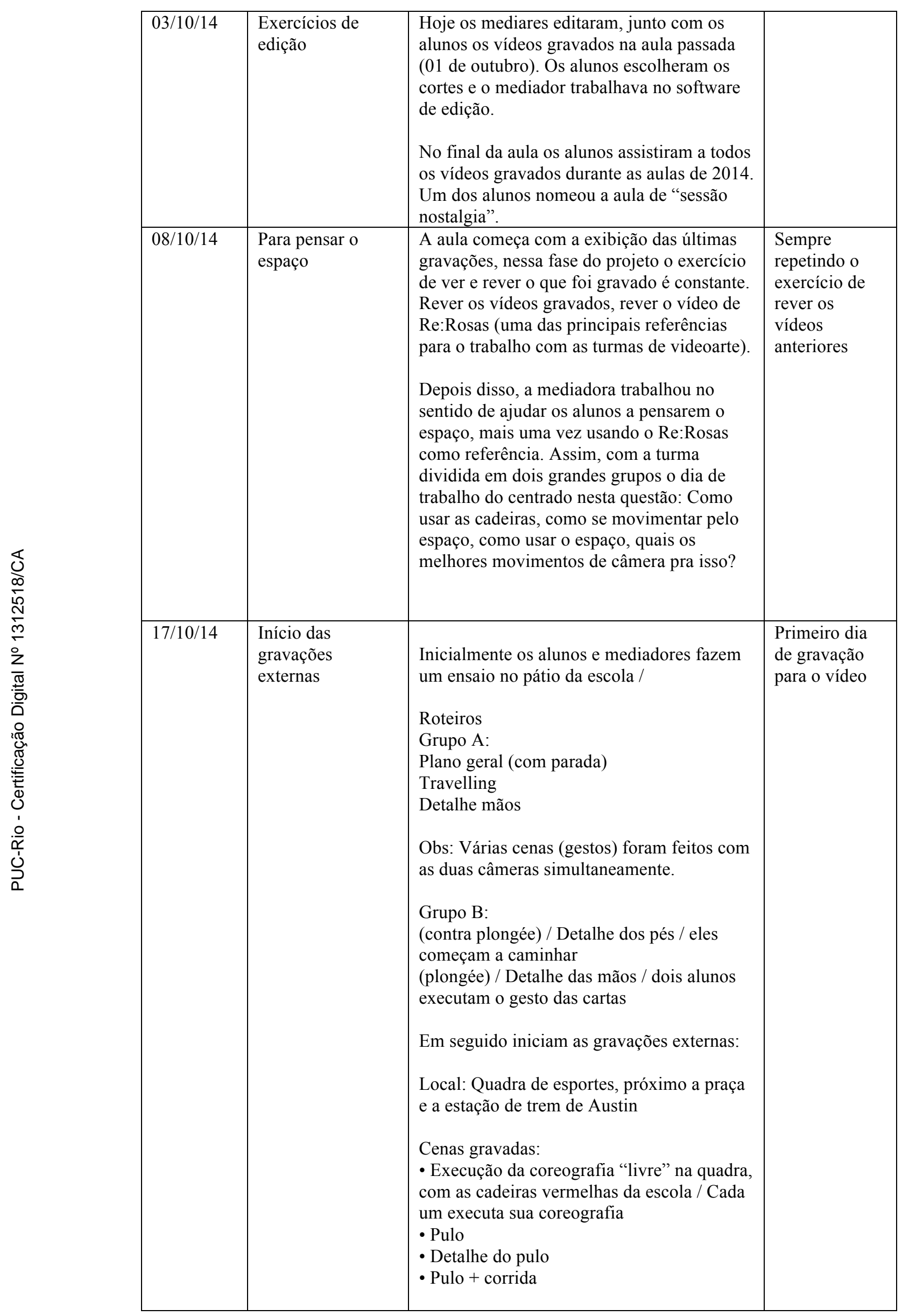




\begin{tabular}{|c|c|c|c|c|}
\hline & $22 / 10 / 14$ & $\begin{array}{l}\text { Recalculando a } \\
\text { rota }\end{array}$ & $\begin{array}{l}\text { Nesta fase de gravação existe um } \\
\text { preocupação dos mediadores: a conexão } \\
\text { entre os trabalhos desenvolvidos em cada } \\
\text { turma. Diante disso, ao iniciar a aula os } \\
\text { mediadores e alunos procuram assistir aos } \\
\text { vídeos gravados. } \\
\text { A segunda parte da aula é um ensaio no } \\
\text { terraço. Cada aluno executa um gesto e é } \\
\text { feito um ensaio do percurso feito pela } \\
\text { câmera. Esse exercício é repetido inúmeras } \\
\text { vezes. } \\
\text { Gravação externa: } \\
\text { Cenário: Ladeira da Igreja católica de } \\
\text { Austin. Os mediadores responsáveis pelas } \\
\text { aulas de linguagem operam as câmeras e a } \\
\text { mediadora responsável pelas aulas de dança } \\
\text { e corpo dirige os alunos na execução dos } \\
\text { gestos. }\end{array}$ & $\begin{array}{l}\text { Preocupação } \\
\text { em fazer algo } \\
\text { que dialogue } \\
\text { com todas as } \\
\text { turmas }\end{array}$ \\
\hline 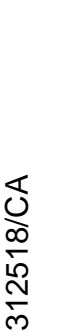 & $28 / 10 / 14$ & Gravação no trem & $\begin{array}{l}\text { A aula começa na sala com a discussão do } \\
\text { material gravado. } \\
\text { Gravação externa: Hoje o cenário de } \\
\text { gravações é o trem (Estação de Austin e } \\
\text { Japeri). } \\
\text { Os ensaios são feitos na própria estação de } \\
\text { trem e dentro do trem. }\end{array}$ & \\
\hline 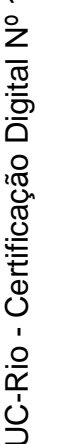 & $31 / 10 / 14$ & $\begin{array}{l}\text { Analisando } \\
\text { material bruto }\end{array}$ & $\begin{array}{l}\text { Último dia de oficina para as turmas de } \\
\text { 2014. Nesta aula os mediadores } \\
\text { apresentaram o material bruto feito com a } \\
\text { turma e juntos selecionaram os vídeos que } \\
\text { farão parte do filme. Foi levado em conta a } \\
\text { qualidade técnica do vídeo e a execução da } \\
\text { coreografia. Depois disso o mediador } \\
\text { explicou aos alunos que todo processo de } \\
\text { edição e montagem do filme seria feito pelo } \\
\text { mediador responsável pelo projeto. }\end{array}$ & \\
\hline
\end{tabular}




\section{Anexo 5}

Telas da plataforma (blog) organizado com o material da empiria, acesso em http://processoelc.tumblr.com/. Senha de acesso: Austin (com A maiúsculo).

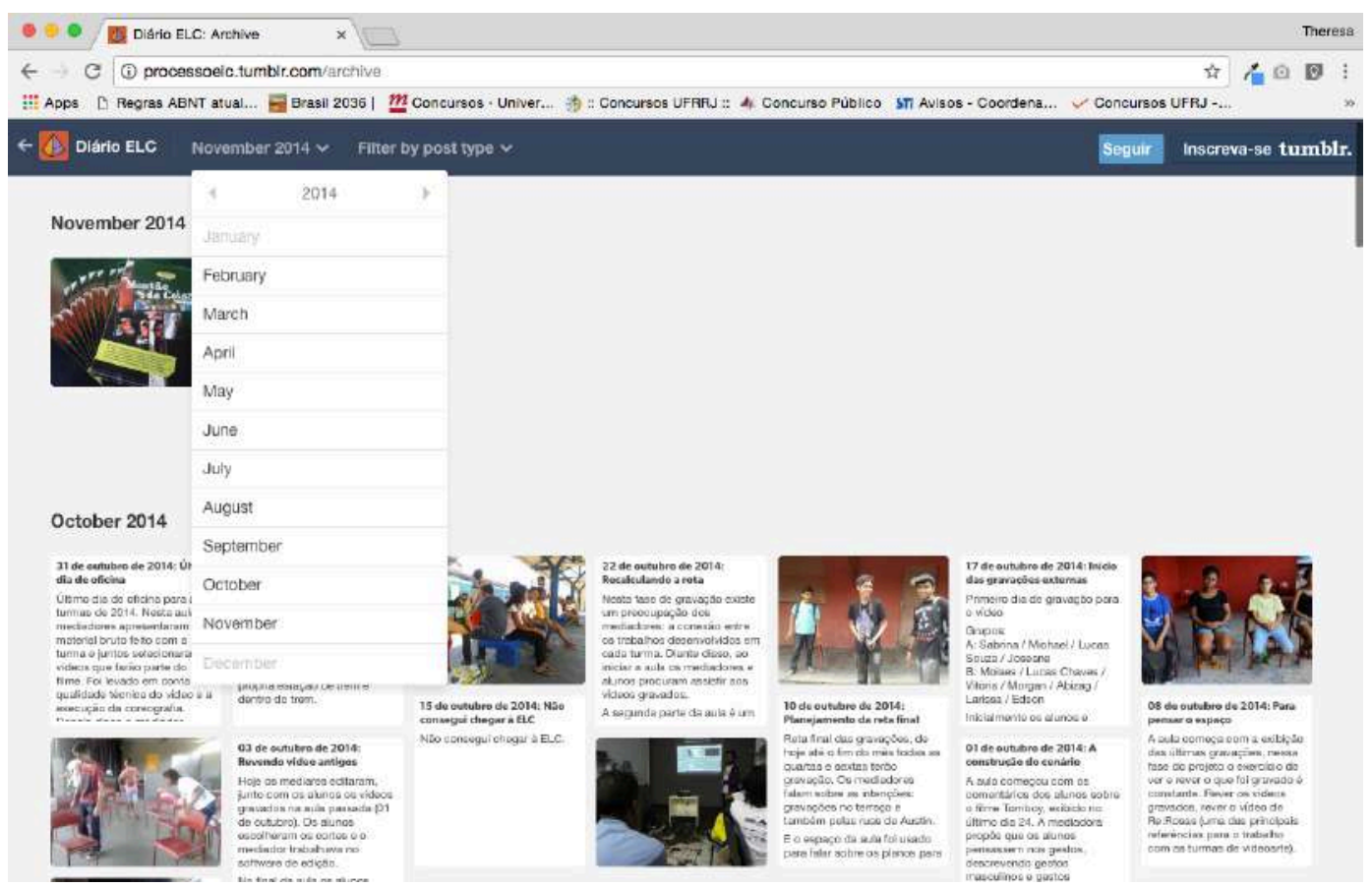

Imagem 49 - Exemplo de filtro por mês e diário das aulas dia a dia - créditos: Theresa Medeiros

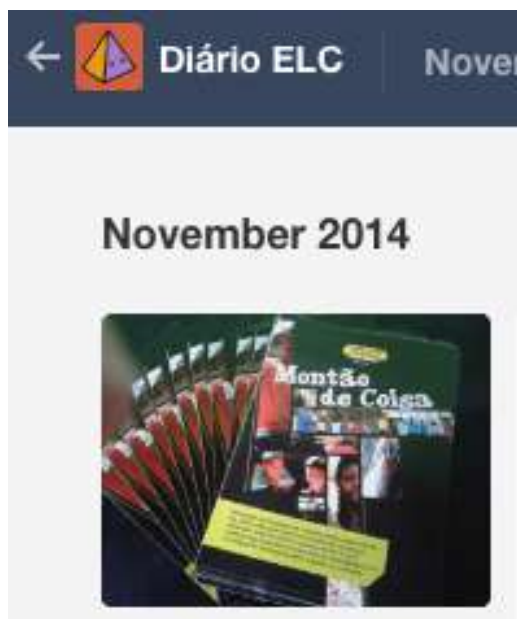

29 de novembro d Lançamento do vis "Montāo de Coisa Lançamento do víc de Coisa", produtc oficinas de videoaa 2014. O lançament no prédio da escol para todos os alun finclusive de outro! slém dos amigos $\epsilon$ alem dos a

\section{Filter by post type $\checkmark$}

圆 All posts

Aa Text

C Photo

66 Quote

P Link

hil Chat

(1) Audio

Video

(3) Ask

\section{October 2014}




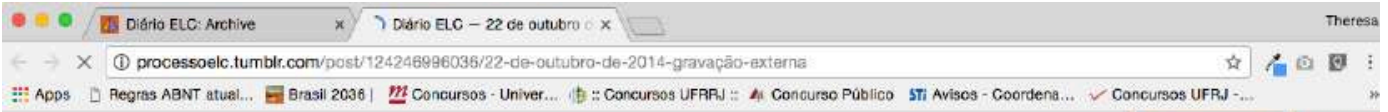

Follow processoale tumblr.

Diário ELC
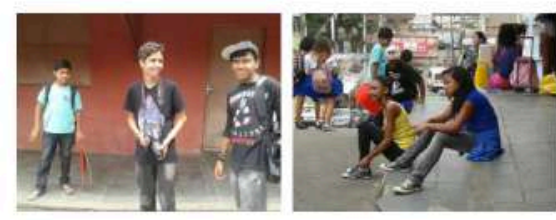

22 de outubro de 2014: Gravação externa

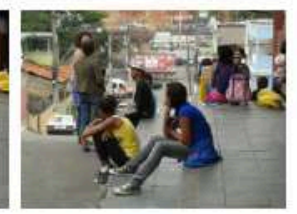

HORAVACAO HLTNOUAGEM HESPACO

D 2013-2017 DIARTO ELC

Imagem 51 - Exemplo de registro de fotos por aula e etiquetas com palavras-chave - créditos: Theresa Medeiros

- Tiario ElC: Archive

$x$ Diario ELC -0 d de outubro o $x$

C (i) processoelc.tumbit.com/post/124241434136/01-de-outubro-de-2014-a-conatruçẳo-do-cenário

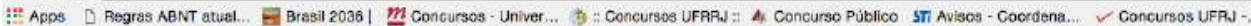

\section{Diário ELC}

\section{1 de outubro de 2014: A construção do cenário}

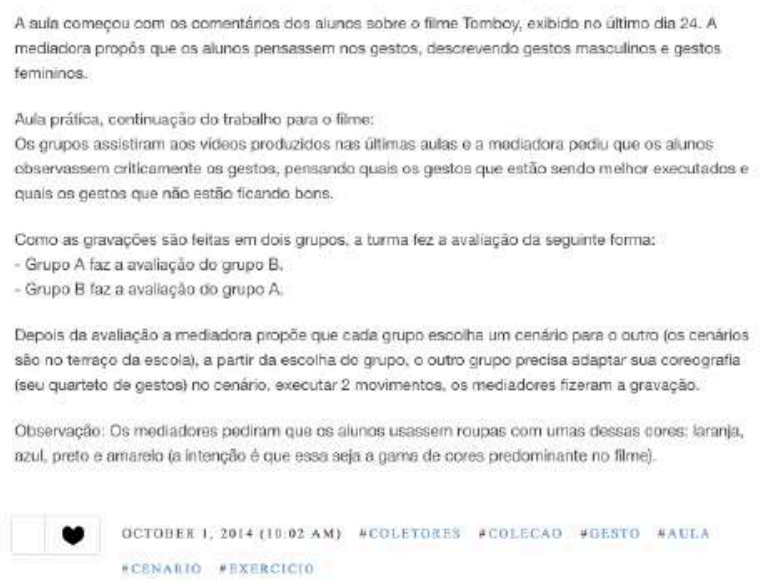

Imagem 52 - Exemplo de registro de aula e etiquetas com palavras-chave - créditos: Theresa Medeiros 